\title{
RELAÇÕES INTERSETORIAIS E INTER-REGIONAIS NA ECONOMIA PARANAENSE EM 1995
}

\section{ANTONIO CARLOS MORETTO}

Economista

Orientador : Prof. Dr. JOAQUIM JOSÉ MARTINS GUILHOTO

Tese apresentada à Escola Superior de Agricultura "Luiz de Queiroz", Universidade de São Paulo, para a obtenção do título de Doutor em Ciências, Área de concentração: Economia Aplicada.

PIRACICABA

Estado de são Paulo - Brasil

Fevereiro - 2000 


\title{
Dados Internacionais de Catalogaçāo na Publicaçāo (CIP) DIVISÃo DE BIBLIOTECA E DOCUMENTAÇÃO - Campus "Luiz de Queiroz"/USP
}

\author{
Moretto, Antonio Carlos \\ Relaçōes intersetoriais e inter-regionais na economia paranaense em 1995 / Antonio
} Carlos Moretto. - P Piracicaba, 2000.

$161 \mathrm{p}$.

Tese (doutorado) - Escola Superior de Agricultura Luiz de Queiroz, 2000.

Bibliografia.

1. Desenvolvimento econômico 2. Economia regional 3. Insumo-produto 4. Relação intersetorial I. Titulo

CDD 330.9

"Permitida a cópia total ou parcial deste documento, desde que citada a fonte - $\mathrm{O}$ autor" 
Amor, carinho, compreensão, alegria de viver... Tudo isso elas me proporcionam. $\grave{A}$ minha esposa, Rossana, $e$ d̀ minha filha, Sarah, dedico esta tese. 


\section{AGRADECIMENTOS}

A realização desta tese não teria sido possível sem a colaboração de pessoas e instituições, às quais muito agradeço.

Ao professor Joaquim José Martins Guilhoto, pela orientação valiosa, estímulo constante, amizade demonstrada e pela oportunidade de um convívio gratificante.

Aos professores Joaquim Bento de Souza Ferreira Filho e Paulo Fernando Cidade de Araújo pelas valiosas sugestões apresentadas.

Ao Professor Pedro Valentim Marques, pelo apoio durante minha permanência em Piracicaba.

Aos professores e funcionários do Departamento de Economia e Sociologia Rural, pelos ensinamentos recebidos e pelo tratamento e ajuda dispensados.

À Universidade Estadual de Londrina e ao Departamento de Economia, pela liberação total das minhas atividades durante o curso de doutorado.

À CAPES que, pelo programa PICDT, prestou auxílio financeiro.

À Professora Graciema Pires Therezo, pela cuidadosa revisão do português.

À colega e amiga Suely, pelo convívio, amizade, apoio e atenção na hora certa.

Aos amigos Ricardo, Cleide e Taline, pelo atenção e grande ajuda quando da chegada em Piracicaba.

Aos colegas de pós-graduação, pelo convívio durante o curso.

À querida 'Tia Angela', pelo carinho, amizade e dedicação demonstrados em todos os momentos.

À Nivea que, embora jovem, soube cuidar de minha filha Sarah, muitas vezes, fazendo o papel de mãe.

Aos meus pais, pelo incentivo e apoio em todos os momentos desta etapa de minha formação acadêmica e, em especial, ao meu irmão Valter, pela valiosa colaboração durante esse período.

Por fim, a todas as pessoas e instituições que colaboraram para a realização desta tese. 


\section{SUMÁRIO}

Página

LISTA DE FIGURAS...........................................................................

LISTA DE TABELAS ............................................................................ vi

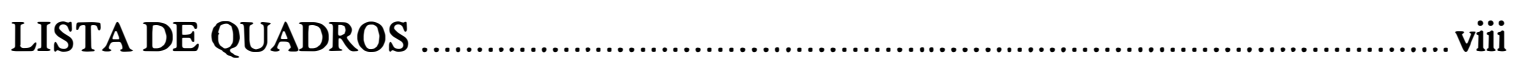

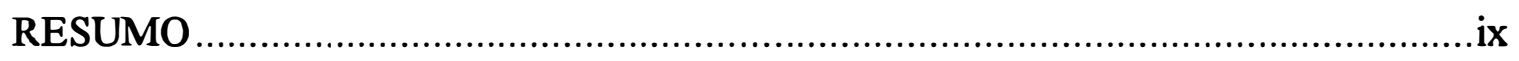

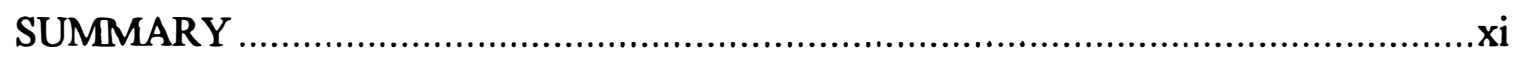

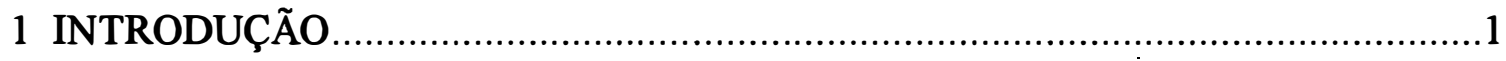

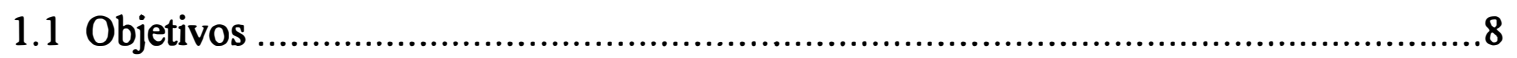

2 TRANSFORMAÇÕES DA ESTRUTURA PRODUTIVA

PARANAENSE: DA OCUPAÇÃO AOS ANOS ........................................ 10

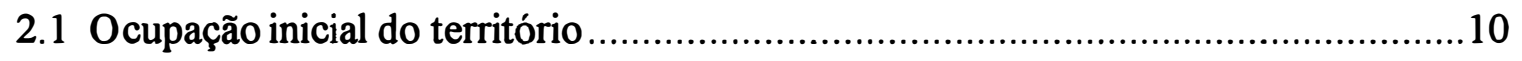

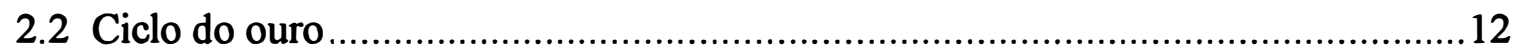

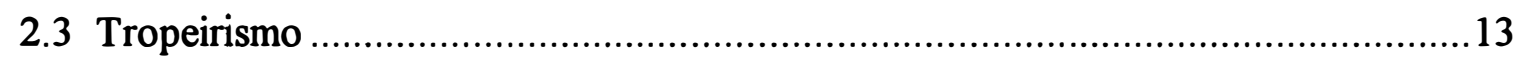

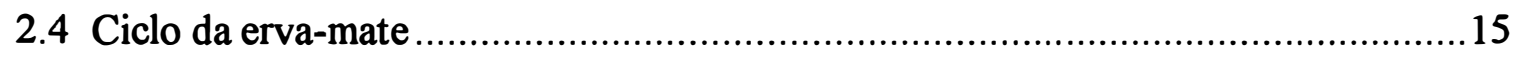

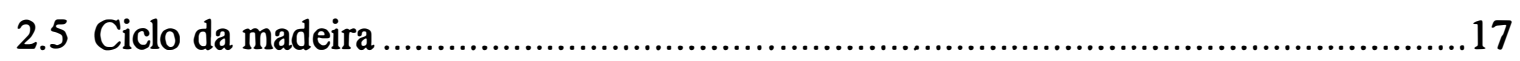

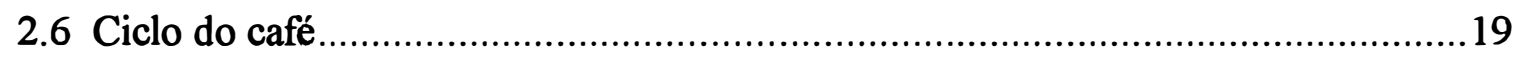

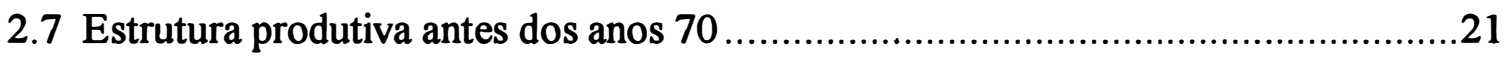

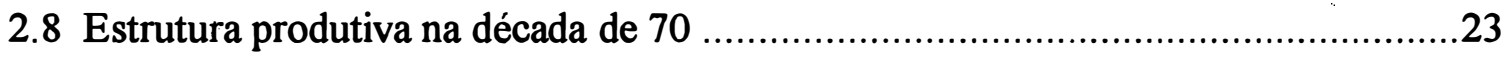

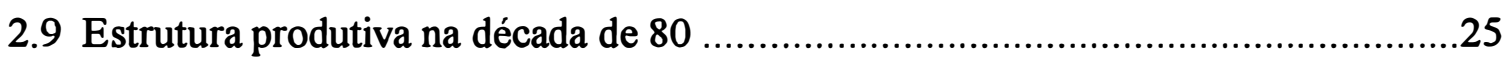

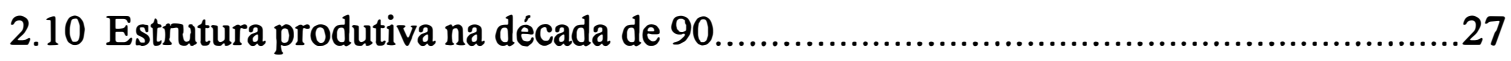

2.11 Distribuição espacial do Produto Interno Bruto paranaense ............................31

2.12 Distribuição espacial da indústria de transformação ........................................32

3. ANÁLISE DO INSUMO-PRODUTO ................................................... 35

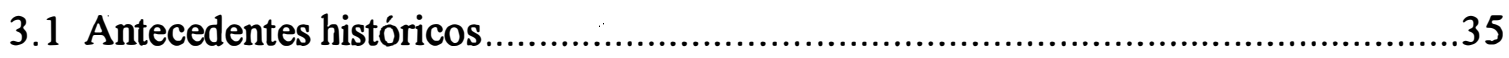

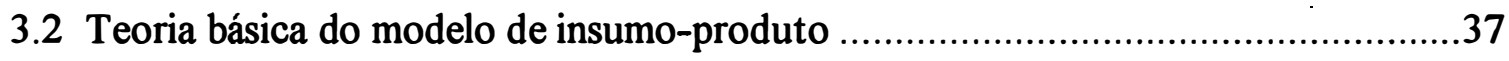

3.3 Modelos de insumo-produto regional ...................................................41 
3.4 Modelos de insumo-produto inter-regionais.............................................42

3.4.1 Modelos de insumo-produto inter-regionais censitários ................................43

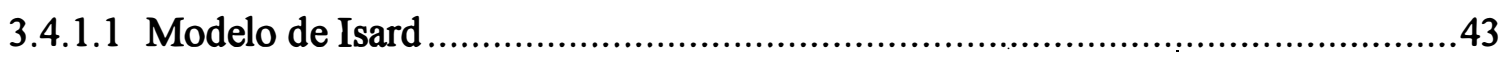

3.4.1.2 Modelo de Metzler...................................................................45

3.4.2 Modelos de insumo-produto inter-regionais parcialmente censitários .................45

3.4.2.1 Modelo de Leontief-Hoffernberg .........................................................45

3.4.2.2 Modelo de Leontief-Strout ............................................................. 47

3.4.2.3 Modelo de Hansen e Tiebout .............................................................48

3.4.2.4 Modelo de Chenery e Moses .............................................................48

3.5 Estrutura básica de modelo inter-regional para duas regiões .............................50

4. METODOLOGIA PARA A CONSTRUÇÃO DA MATRIZ DE INSUMO-

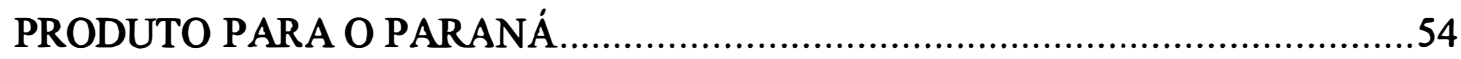

4.1 Matriz de insumo-produto para o Paraná - 1995 ...........................................54

4.1.1 Método do quociente locacional ..........................................................5

4.1.2 Procedimentos de construção da matriz de insumo-produto para o Paraná..........56

4.2 Paraná e as divisões em pólos regionais ....................................................63

5. MÉTODOS DE ANÁLISE DA ESTRUTURA PRODUTIVA............................66

5.1 Índices de ligações e setores-chave na economia...........................................67

5.1.1 Índices de Rasmussen-Hirschman .....................................................68

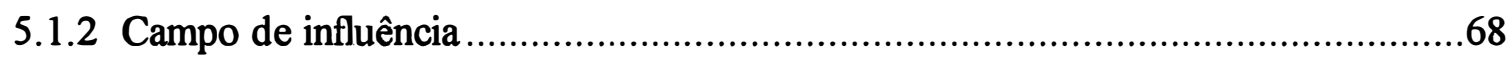

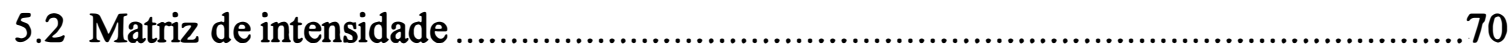

5.3 Índices Puros de Ligações: modelo GHS ................................................... 72

5.4 Interações sinergéticas entre regiões.....................................................76

5.4.1 Multiplicadores regionais internos ..................................................... 77

5.4.2 Bloco de matrizes inversas de Leontief e a classificação do bloco de matrizes dos multiplicadores externos à esquerda e à direita ........................80

5.4.3 Decomposição hierárquica aditiva dos blocos inversos de Leontief ...................83

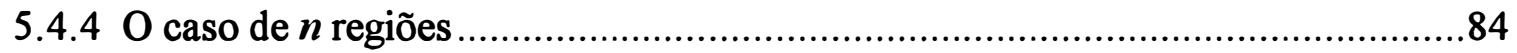




\section{ANÁLISE DAS RELAÇÕES INTERSETORIAIS E INTER-REGIONAIS}

NA ECONOMIA PARANAENSE 87

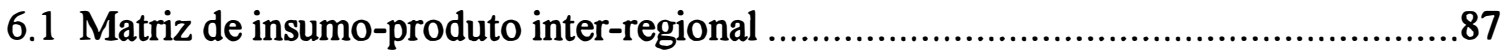

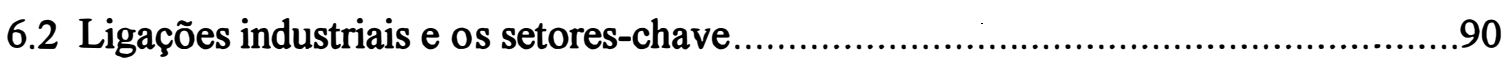

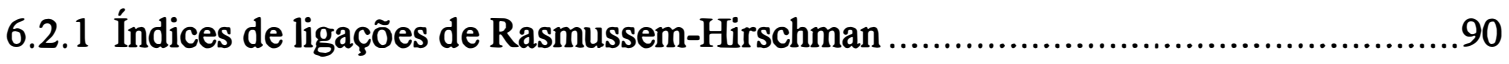

6.2.2 Campo de influência, Paraná e o sistema inter-regional .....................................99

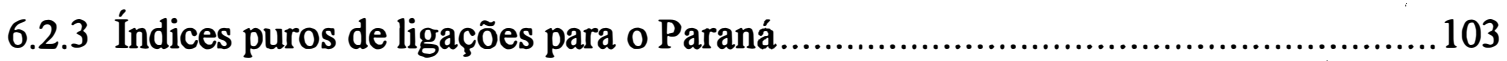

6.2.3.1 Índices puros de ligações para o sistema inter-regional .................................... 105

6.2.3.2 Comparação e consolidação dos índices de Rasmussem-Hirschman e puros ...110

6.3 Matriz de intensidade e as diferentes estruturas econômicas..................................112

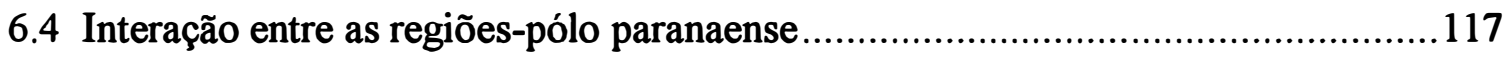

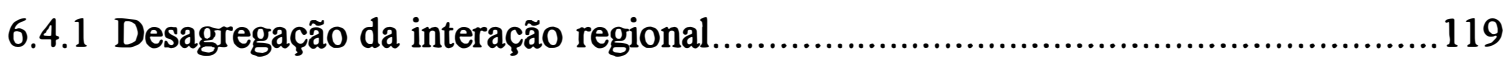

6.4.1.1 Desagregação setorial: impactos da demanda final própria ............................120

6.4.1.2 Desagregação setorial: impactos da demanda final de outras regiões..............122

6.5 Interações sinergéticas entre as regiões-pólo ...................................................124

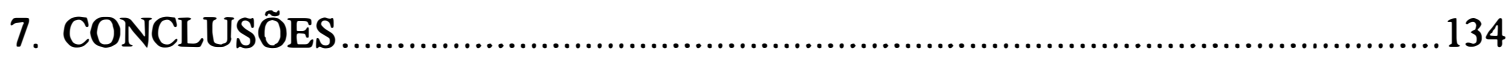

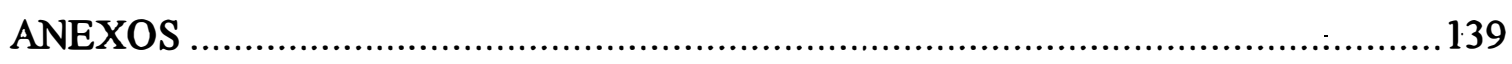

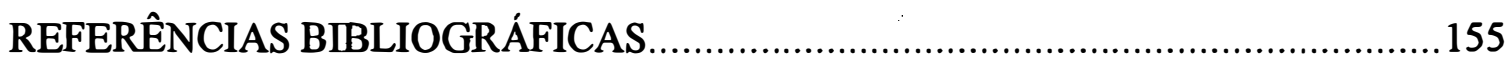




\section{LISTA DE FIGURAS}

Página

Figura 2.1 - Participação relativa da renda paranaense, segundo os setores de atividade, 1939 e 1947-1967.

Figura 2.2. - Participação percentual das classes de atividade no PIB ${ }_{\text {cf, Paraná, }}$ 1980-95.

Figura 4.1 - Paraná e sua divisão em pólos regionais. 65

Figura 5.1 - Representação esquemática das formas possíveis da matriz $A_{1}$ - o caso de 2 regiões.

Figura 5.2 - Representação esquemática das formas possíveis da matriz $A_{1}$ - o caso de 4 regiões.

Figura 6.1 - Padrão médio dos Índices de ligações de Rasmussen-Hirschman para os pólos regionais, Paraná, 1995.

Figura 6.2 - Índices de ligações de Rasmussen-Hirschman, Paraná, 1995. 94

Figura 6.3 - Índices de ligações de Rasmussen-Hirschman, pólo regional de Curitiba, 1995. 96

Figura 6.4 - Índices de ligações de Rasmussen-Hirschman, pólo regional de Londrina, 1995. 96

Figura 6.5 - Índices de ligações de Rasmussen-Hirschman, pólo regional de Ponta Grossa, 1995.

Figura 6.6 - Índices de ligações de Rasmussen-Hirschman, pólo regional de Cascavel, 1995. 98

Figura 6.7 - Coeficientes setoriais com maior campo de influência, Paraná, 1995.

Figura 6.8 - Coeficientes setoriais com maior campo de influência no sistema inter-regional, Paraná, 1995.

Figura 6.9 - Índices puros de ligações para frente, trás e total, Paraná, 1995. 105

Figura 6.10 - Índice puro de ligações para frente para o sistema inter-regional, Paraná, 1995. 
Figura 6.11 - Índice puro de ligações para trás para o sistema inter-regional, Paraná, 1995.

Figura 6.12 - Topografia da estrutura da economia do Paraná, 1995.

Figura 6.13 - Topografia da estrutura da economia do P. R. de Curitiba usando a hierarquia do Paraná, 1995.

Figura 6.14 - Topografia da estrutura da economia do P. R. de Londrina usando a hierarquia do Paraná, 1995.

Figura 6.15 - Topografia da estrutura da economia do P. R. de Ponta Grossa usando a hierarquia do Paraná, 1995.

Figura 6.16 - Topografia da estrutura da economia do P. R. de Cascavel usando a hierarquia do Paraná, 1995

Figura 6.17 - Produção, por pólo regional e setores, induzida pela demanda final própria, Paraná, 1995.

Figura 6.18 - Participação da demanda final das outras regiões-pólo na indução da produção setorial do P. R. de Curitiba, Paraná, 1995.

Figura 6.19 - Participação da demanda final das outras regiões-pólo na indução da produção setorial do P. R. de Ponta Grossa, Paraná, 1995.

Figura 6.20 - Participação da demanda final das outras regiões-pólo na indução da produção setorial do P. R. de Londrina, Paraná, 1995.

Figura 6.21 - Participação da demanda final das outras regiões-pólo na indução da produção setorial do P. R. de Cascavel, Paraná, 1995.

Figura 6.22 - Pólo Regional de Curitiba: contribuição (\%) de cada matriz para a participação total de $\left(y_{1}-f\right)$ em $y$ para as regiões-pólo, Paraná, 1995

Figura 6.23 - Pólo Regional de Ponta Grossa: contribuição (\%) de cada matriz para a participação total de $\left(y_{1}-f\right)$ em $y$ para as regiões-pólo, Paraná, 1995

Figura 6.24 - Pólo Regional de Londrina: contribuição (\%) de cada matriz para a participação total de $\left(y_{1}-f\right)$ em $y$ para as regiões-pólo, Paraná, 1995

Figura 6.25 - Pólo Regional de Cascavel: contribuição (\%) de cada matriz para a participação total de $\left(y_{1}-f\right)$ em $y$ para as regiões-pólo, Paraná, 1995 


\section{LISTA DE TABELAS}

Tabela 2.1. Composição relativa da renda interna paranaense, segundo os

Página setores de atividade e a participação no Brasil, 1939 e 1947-1967.

Tabela 2.2. Taxas médias anuais de crescimento do Produto Interno Bruto, por classes de atividades, no Paraná e Brasil, 1970-1980

Tabela 2.3. Participação percentual das classes de atividade no PIB, a custo de fatores, Paraná, 1980-95.

Tabela 2.4. Distribuição espacial do Produto Interno Bruto a custo de fatores, por MRH e ramos de atividade econômica, Paraná, 1995

Tabela 2.5. Distribuição do valor adicionado da indústria de transformação por microrregião homogênea, Paraná: 1975 - 1994.

Tabela 4.1. Constituição das regiões-pólo do Paraná, conforme a distribuição

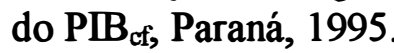

Tabela 6.1. Marriz de insumo-produto do sistema inter-regional, Paraná, 1995. 89

Tabela 6.2. Índices de ligações de Rasmussen - Hirschman para o sistema interregional e Paraná, 1995

Tabela 6.3. Índices puros para frente, trás e total, Paraná,1995. 104

Tabela 6.4. Índices puros de ligações para o sistema inter-regional, Paraná, 1995.

Tabela 6.5. Setores-chave consolidados - índices de ligações de RasmussenHirschman (R-H) e os índices puros totais, Paraná e sistema interregional, 1995.

Tabela 6.6. Ligações puras para trás, frente e total para o sistema interregional, Paraná, 1995.

Tabela 6.7. Composição da produção dos pólos regionais, segundo indução da demanda final própria e do resto do Paraná, 1995. 
Tabela 6.8. Participação da produção dos pólos regionais no total do Paraná, segundo indução da demanda final própria e do resto do Paraná, 1995.

Tabela 6.9. Produção dos pólos regionais induzidas pelas demandas finais, Paraná, 1995.

Tabela 6.10. Contribuição (\%) das combinações 1, 2, 3, 4 e 5 dos blocos de matrizes para a produção em cada região-pólo, Paraná, 1995.

Tabela 6.11. Contribuição (\%) de cada matriz para a participação total de $\left(y_{1}-f\right)$ em $y$ para as regiões-pólo, Paraná, 1995.

ANEXO A. Matriz de insumo-produto do sistema inter-regional, Paraná, 1995 .134 


\section{LISTA DE QUADROS}

Quadro 3.1. Quadro simplificado de um modelo de insumo-produto inter-

Página regional

Quadro 4.1. Agregação dos setores usados na construção do sistema inter-regional do Paraná.

Quadro 4.2. Produtos componentes dos setores do sistema inter-regional do Paraná. .58

Quadro 4.3. Relações de insumo-produto usadas na construção das matrizes para o Paraná 60

Quadro 5.1. Multiplicadores regionais internos e sua propriedades .79

Quadro 5.2. Ordenação das interações sinergéticas entre os subsistemas econômicos. 


\title{
RELAÇÕES INTERSETORIAIS E INTER-REGIONAIS NA ECONOMIA PARANAENSE EM 1995
}

\author{
Autor: ANTONIO CARLOS MORETTO \\ Orientador: Prof. Dr. JOAQUIM JOSÉ MARTINS GUILHOTO
}

\section{RESUMO}

As profundas transformações ocorridas na década de 70 e a progressiva diversificação do aparelho produtivo, nos anos 80 e 90, modificaram a composição interna e as relações inter e intra-setoriais e inter-regionais da economia paranaense. Assim, o objetivo desta tese foi identificar as principais regiões-pólo, os setores com maior potencial de encadeamento e as interdependências setoriais e regionais da estrutura produtiva do Estado. Com esses fins, estimou-se e implementou-se, para o ano de 1995, um modelo inter-regional de insumo produto, no qual o Paraná foi dividido em 4 regiões-pólo: Curitiba, Ponta Grossa, Londrina e Cascavel. Para atingir os objetivos propostos foram utilizados os seguintes modelos de análises: índices de ligações para frente e para trás de Rasmussem e Hirschiman; campo de influência; matriz de intensidade; índices puros de ligações e interações sinergéticas entre regiões.

Os principais resultados indicam que os pólos regionais de Curitiba e de Londrina possuem suas estruturas industriais melhor articuladas, enquanto as regiõespólo de Ponta Grossa e Cascavel buscam, ainda, implementar e consolidar seus sistemas produtivos. As ligações intersetoriais revelam o setor Celulose, Papel e Gráfica como chave para o conjunto da economia paranaense e para os pólos regionais de Curitiba e Ponta Grossa. Além deste, foram setores-chave a Fabricação de Minerais não Metálicos e Material de Transporte para Curitiba e a Indústria Têxtil para a região-pólo de Londrina e para o Paraná. 
Os coeficientes com maior campo de influência revelam que os principais elos de ligações são dominados por setores diretamente vinculados à economia dos pólos regionais de Curitiba e Ponta Grossa.

Os índices puros de ligações para frente e para trás para o sistema interregional denotam que a importância de cada pólo regional para a economia paranaense é bastante diferenciada e comprovam a supremacia da região-pólo de Curitiba. Isso indica que o perfil de maior reciprocidade ou integração econômica será estabelecido por esta região, cabendo à região de Londrina o papel de segunda indutora do sistema.

A comparação da estrutura econômica dos pólos regionais com a do Paraná mostrou que a de Londrina, Ponta Grossa e Cascavel assemelha-se à paranaense, ao passo que a região-pólo de Curitiba apresentou sua estrutura produtiva mais interligada e diferenciada.

As interações sinergéticas entre as regiões evidenciaram que o pólo regional de Curitiba foi mais dependente das outras regiões do sistema, enquanto que as relações internas de produção da região de Londrina mostram uma estrutura produtiva mais fechada. 


\title{
INTERSECTORAL AND INTERREGIONAL RELATIONS IN THE ECONOMY OF THE STATE OF PARANA, BRAZIL, IN 1995
}

\author{
Author: ANTONIO CARLOS MORETTO \\ Adviser: Prof. Dr. JOAQUIM JOSÉ MARTINS GUILHOTO
}

\section{SUMMARY}

The deep transformations that happened in the 70's and the progressive economical diversification in the 80's and 90's changed the internal composition and the intersectoral and interregional relations in the economy of the state of Parana, Brazil. Thus, the aim of this study was to identify the principal pole-regions, the sectors with the greatest linking potential and the intersectoral and interregional interdependence of the productive structure of the said state. To achieve this aim it was built and implemented an interregional input-output table for the year of 1995 in which the state of Parana was divided in four pole-regions: Curitiba, Ponta Grossa, Londrina and Cascavel. The main analytical tools (all described in the text) used in this work refers to: the Rasmussem and Hirschiman backward and forward linkages; the field of influence; the intensity matrix; the pure linkage and the synergetic interactions among regions.

The main results show that the productive structure of the pole-regions of Curitiba and Londrina is better arranged than that of the pole-regions of Ponta Grossa and Cascavel, which are still trying to implement and consolidate theirs. The intersector linkings reveal that Cellulose, Paper and Printing is a key- sector in the economy of Paraná as a whole and also in the economy of the pole-regions of Curitiba and Ponta Grossa. Besides this sector, Non-Metalic Minerals and Transport Equipment were also key-sectors for Curitiba. The Textile Industry had a fundamental role in the economy for the pole-region of Londrina and for Parana as a whole. 
The coefficients with greater field of influence reveal that the main links are determined by the sectors directly linked to the economy of the pole-regions of Curitiba and Ponta Grossa.

The forward-backward pure linkage for the interregional system denotes that the importance of each pole-region for the economy of Paraná varies widely and prove the supremacy of the pole-region of Curitiba. This supports the idea that the profile of higher reciprocity or economic integration will be established by this region, Londrina being attributed second place.

The comparison between the economic structure of the pole-regions with that of Parana showed that the economic structure of Londrina, Ponta Grossa and Cascavel is similar to that of the state as a whole, while the economic structure of the pole-region of Curitiba is more linked and differenciated .

The synergetic interactions among the regions showed that the pole-region of Curitiba was more dependent on the other regions of the system whereas the internal production relations of the region of Londrina showed a more closed productive structure. 


\section{INTRODUÇÃO}

O processo de desenvolvimento econômico por que passam as economias é caracterizado por profundas transformações das estruturas econômicas, políticas e sociais resultando em melhor padrão de vida da maioria da população. A transformação da estrutura produtiva culmina com o aprofundamento da interdependência entre os diferentes setores da economia: primário, secundário e terciário. Tal interdependência estabelece que a dinâmica de cada setor produtivo influencia e é influenciada pelas mudanças tecnológicas ocorridas nos outros setores, via difusão de inovações (Farina e Zylberstajn, 1992).

A industrialização brasileira começou no decorrer dos anos trinta. Nessa década, o Brasil entrou propriamente na fase de sua Revolução Industrial. As transformações, daí decorrentes, surgiram do rompimento de suas bases agrárias tradicionais de caráter basicamente colonial. Dentre os diversos ciclos econômicos por que a economia brasileira passou, sem dúvida, o do café apresentou características diversas em relação aos anteriores. Segundo Bresser Pereira (1987), a diferença fundamental está no fato de que, com o café, começa a ser usado, em grande escala, o trabalho assalariado, em substituição ao trabalho escravo. Desta forma, a remuneração do trabalho permitiu a formação de um incipiente mercado interno, dando as condições iniciais para a instalação de uma indústria nacional emergente orientada para o seu abastecimento.

O processo de industrialização brasileiro, fundamentado no modelo de substituição de importações, concentrou seu parque industrial, basicamente, no Estado de São Paulo, ficando as demais unidades da Federação à margem do crescimento industrial. Segundo Cano (1990), o Estado de São Paulo, em 1907, concentrava 15,9\% 
do valor bruto da produção, enquanto o antigo Estado da Guanabara era o principal produtor com $30,2 \%$. Ainda, de acordo com autor, esta situação já teria sido revertida em 1919, quando São Paulo ultrapassou a Guanabara e assumiu, definitivamente, a dianteira na indústria brasileira, respondendo por $31,5 \%$ do valor bruto da produção nacional contra $17,0 \%$ daquele Estado. A partir daí, a industrialização paulista foi tão intensa que, em 1939, o Estado já era responsável por $45,4 \%$ de toda a produção industrial brasileira. $\mathrm{O}$ processo de industrialização paulista, dessa forma, conseguiu estabelecer vínculos de dependência, cada vez mais estreitos, com o resto do país. Assim, outras regiões do Brasil, que antes viviam subordinadas à periferia do exterior, passaram a depender e gravitar em torno do dinâmico centro industrial emergente. É neste sentido que Padis (1981) classificou a economia paranaense de periférica.

A exemplo da economia brasileira, a paranaense passou por vários ciclos econômicos desde a sua ocupação, a saber: ouro, tropeirismo, mate, madeira, café e, mais recentemente, soja, os quais serão discutidos com mais detalhes no capítulo 2 . 0 estudo destes diversos ciclos econômicos, lệa a inferir que a economia paranaense esteve, basicamente, voltada para o mercado internacional, como exportadora de matérias-primas e importadora de bens de consumo em geral.

Até 1929, o mate foi o principal produto na pauta de exportação paranaense, bem como a principal fonte de arrecadação de impostos. Segundo Padis (1981), o mate, sozinho, chegou a contribuir com $98 \%$ do valor total das exportações no início deste século e, ao mesmo tempo, foi responsável por mais de $40 \%$ do total da arrecadação dos impostos do Estado.

Após a crise de 29, as possibilidades da economia paranaense eram bastante limitadas. Concomitantemente, as dificuldades que se apresentavam eram de monta considerável. A infra-estrutura do sistema econômico estadual, principalmente a do sistema viário, era extremamente deficiente, constituindo-se no principal obstáculo para o escoamento dos produtos paranaenses. Como o setor externo era o principal responsável pela geração de renda e de capacidade de importar, percebe-se que a obtenção de bens de capital não constituía uma tarefa fácil. De fato, como salienta Padis (1981), o sistema econômico tinha características eminentemente pré-capitalistas, de 
infra-estrutura fisica, técnica e financeira acanhada, não suportando a expansão capitalista.

O início da década de 40 foi marcado pelo predomínio das atividades primário-exportadoras. $\mathrm{O}$ setor industrial era inexpressivo. Nesse período, os dois principais ramos da atividade industrial, madeira e mobiliário e produtos alimentares, compreendiam $63 \%$ dos estabelecimentos, empregavam $62 \%$ da mão-de-obra, pagavam $61 \%$ dos salários, produziam $70 \%$ do valor total da produção e eram responsáveis por $61 \%$ do valor adicionado (Magalhães Filho, 1996). O ramo de madeira e mobiliário era composto, basicamente, por serraria de pinho, que, em 1943, foi responsável por 49,5\% das exportações paranaenses. A partir desta data, a participação nas exportações tem apresentado um forte declínio. Isto foi atribuído à redução das reservas florestais do Estado, bem como à inclusão de outros artigos na pauta de exportação (Carmo, 1981).

Por outro lado, o setor de produtos alimentares se constituía, principalmente, do beneficiamento da erva-mate, de cereais, panificação e fabricação de massas alimentícias e biscoitos.

Em 1942, o Paraná participava com apenas $2,4 \%$ do valor da produção industrial brasileira (Magalhães Filho, 1996).

A expansão da fronteira agrícola do café paulista deu um grande impulso à ocupação do Norte do Paraná, principalmente após os anos 40 . No início da década de 60 , o Estado assumiu a dianteira na produção nacional do café, atingindo, na safra 62/63, $62,8 \%$ da produção brasileira (Padis, 1981). Sendo o maior produtor nacional, o Paraná tornou-se o principal gerador da capacidade nacional de importar. $O$ significado econômico, para o Estado, tem sido profundamente diverso daquele observado em São Paulo. Neste último, as poupanças eram canalizadas, principalmente, para os investimentos industriais dentro do próprio Estado, enquanto, no Paraná, isto não ocorria, dado que, à época do desenvolvimento da cafeicultura, a demanda por produtos industrializados era quase totalmente atendida pela produção paulista.

$\mathrm{Na}$ realidade, a região norte paranaense, desde a sua ocupação, permanecia praticamente isolada do resto do Estado, principalmente da capital, devido, sobretudo, à ausência de meios de comunicação. A falta de investimentos públicos ligando as duas 
regiões, certamente, trouxe graves prejuízos à economia paranaense, não só porque passou a provocar a evasão de boa parte da renda gerada internamente mas, também, porque de forma crescente a região Norte se vinculava e se tornava mais dependente do Estado de São Paulo (Padis, 1981).

No período de 1940 a 1970, o Estado do Paraná sofreu grandes transformações na sua estrutura produtiva. No início, a maior parte do seu território ainda estava por ser ocupada e a população era bastante reduzida. Nessa fase, segundo Padis (1981), a renda interna estadual cresceu num ritmo superior ao do país. Vale mencionar que em 1937 a participação relativa da renda interna era de $3 \%$ da nacional, atingindo, em 1967, 6,5\%.

A composição da renda interna por setores de atividade, no período acima mencionado, revela que o setor primário era o principal gerador de renda. De acordo com Padis (1981), em 1939, esse setor foi responsável por $48,5 \%$ da formação da renda interna, enquanto o setor secundário e o terciário responderam, respectivamente, por $14 \%$ e $37,5 \%$. No final do período, na média de $1965 / 67$, a situação pouco se alterou. 0 setor primário foi responsável por $45 \%$ da renda total gerada no Estado, enquanto o secundário, por $10,7 \%$ e o terciário por $44,3 \%$.

No decorrer dos anos 70, a indústria paranaense passou por um acentuado processo de transformação, caracterizado pelo dinamismo e diversificação do parque industrial, notadamente pela instalação de novas fábricas no Estado. De acordo com IPARDES (1986), o Produto Interno Bruto Real do Paraná cresceu a uma taxa média de $18,8 \%$ ao ano, no período $1970-74$, bem superior ao crescimento médio de $11,6 \%$ registrado para o Brasil. Esta expansão ocorreu em todos os setores da economia estadual, em que o crescimento médio anual da agricultura foi de $14,5 \%$, o da indústria, de $23 \%$ e o do comércio, de $19,5 \%$. Já, no período seguinte, 1974-80, em função do choque do petróleo, a economia brasileira apresentou uma desaceleração no seu ritmo de crescimento. A taxa média de incremento do PIB do Brasil caiu para 6,6\% em relação ao início da década. No Paraná, o efeito foi similar, porém registraram-se taxas ainda maiores do que as do Brasil, $9,9 \%$ ao ano no mesmo período. 
O dinamismo da economia paranaense, na década de 70 , não pode ser compreendido apenas pelos elevados índices de crescimento mas, principalmente, pelas transformações estruturais ocorridas nos setores produtivos de todo o Estado. A agricultura foi o segmento que sofreu rápida transformação e modernização, estreitou relações com a indústria e com o comércio, não somente como demandante de insumos modernos, máquinas e equipamentos agrícolas, mas como fornecedora de matériasprimas industriais, além de suprir o abastecimento alimentar rural e urbano no Estado (IPARDES, 1986).

Por outro lado, com a diversificação da estrutura industrial, setores tradicionais, como o de madeira, cedem à incorporação de gêneros mais dinâmicos, como os químicos e materiais elétricos e de comunicação. É importante ressaltar que essa dinâmica permitiu ampliar as relações inter e intra-setoriais, impulsionando o parque fabril paranaense. $\mathrm{O}$ reflexo foi o aumento do número de empresas de maior porte que, geralmente, empregam tecnologias mais modernas, incrementando seus índices de produtividade.

A década de 80 foi um período de declínio da tendência de rápido crescimento e diversificação do aparelho produtivo estadual iniciado na década anterior. Mesmo assim, a economia paranaense apresentou taxa de crescimento bem superior à registrada para o país. No período de 1980 a 1989, o seu PIB cresceu 5,7\% ao ano contra a média nacional de $2,8 \%$ (Lourenço, 1994). As razões desse crescimento devem-se à expansão da oferta agropecuária; continuidade da diversificação agroindustrial; maturação plena de grandes inversões realizadas em segmentos modernos com destaque para micro e minicomputadores, ônibus e caminhões, papel de imprensa, cigarros, malte, fertilizantes, etc.; maturação de investimentos em aumento da capacidade produtiva efetuados pelas empresas do complexo metal-mecânica, além da materialização de grandes inversões realizadas nos segmentos industriais de cimento, papel, madeira e café solúvel.

As profundas transformações ocorridas na década de 70 e a progressiva diversificação do aparelho produtivo paranaense nos anos 80, modificaram a composição interna da economia. De acordo com IPARDES (1991), o setor 
agropecuário, apesar de apresentar crescimento e expressiva modernização, teve sua participação reduzida na renda. Em 1980 o setor participava com 19,4\% da renda total, contra $14 \%$ em 1989. Por outro lado, o setor industrial, apesar do sensível incremento da capacidade produtiva, sofreu uma pequena redução na composição da renda interna, de $28,8 \%$ para 26,3\% em 1980 e 1989, respectivamente. Contrariamente, o setor serviços teve sua participação aumentada de $51,8 \%$ para $59,7 \%$ no mesmo período, seguindo a tendência observada nas economias em desenvolvimento.

Procurando eliminar as pressões inflacionárias, o Governo Collor promoveu um brutal enxugamento de liquidez na economia, por meio de aperto monetário, contenção fiscal, atrasos tarifários e cambiais e arrocho salarial, o que propiciou um aprofundamento da trajetória recessiva na economia brasileira no final de 1989. O desempenho de 1990 foi pior do que o dos anos recessivos da década de 80. 0 declínio do PIB brasileiro, cuja queda foi liderada pelo setor industrial, foi da ordem de $4,6 \%$. No Paraná, os efeitos foram mais acentuados, devido ao predomínio da agropecuária e da agroindústria na estrutura produtiva do Estado, resultando numa retração de 6,6\% do PIB. A agropecuária recuou 9,7\%. Na indústria, a queda foi de 4,8\% (IPARDES, 1991).

No período de 1991 a 1994, a produção industrial paranaense cresceu 19,09\%. As atividades metalurgia, mecânica, material elétrico e de comunicações, material de transportes, química, produtos alimentares e fumo registraram as maiores taxas de crescimento da produção. Durante os dois últimos anos do período, a expansão do PIB estadual foi liderada pela ampliação da renda do setor primário e seus efeitos multiplicadores dinâmicos para-frente e para-trás, especialmente os setores de fabricação e venda de insumos, máquinas e implementos, comércio interno e externo, mercado de imóveis e bens duráveis, aplicações financeiras, transportes rodoviário e ferroviário, dentre outros (Lourenço, 1995).

Essa expansão industrial foi, também, conseqüência dos primeiros resultados da integração comercial do país com o Mercado Comum do Sul (Mercosul). Os dados mostram que as exportações paranaense passaram de US\$1,868 bilhões em 1990 para US\$ 4,246 bilhões em 1996, significando um incremento de 127,3\%, bastante superior ao observado para o Brasil, 51,9\% no mesmo período (IPARDES, 1997b). 
O maior intercâmbio comercial com os países integrantes do Mercosul, além de propiciar uma sensível elevação do fluxo das exportações paranaenses, permitiu que vários setores industriais processassem ajustes técnicos, produtivos e gerenciais na busca rápida de melhoria dos padrões de eficiência, produtividade e competitividade. Nesse sentido, Nojima (1995) salienta que um grupo considerável de gêneros industriais vem buscando maior nível de eficiência elevando sua produtividade. $\mathrm{O}$ referido autor ressalta que a elevação da produtividade possibilitou a ampliação do emprego nos gêneros mecânica, material de transportes, material elétrico, mobiliário e produtos alimentares. Por outro lado, em alguns setores, os ganhos de produtividade decorreram da forte redução dos quadros funcionais, vinculada à reorganização de processo e/ou a implantação de tecnologias poupadoras de mão-de-obra, como parece ter ocorrido nos segmentos química, bebidas, papel e papelão e minerais não-metálicos.

Ainda dentro deste contexto, o segmento agroindustrial, principal componente da indústria paranaense, amplia-se quantitativamente e consolida-se qualitativamente nessa primeira metade dos anos 90. Segundo Urban (1995), a pauta de produção apresentou uma significativa diversificação com a criação de novos produtos, bem como as plantas agroindustriais se concentraram e verticalizaram, com destaque para os segmentos café solúvel, óleos vegetais, laticínios, fiação, suco de laranja e carnes, especialmente aves e seus derivados.

$\mathrm{Na}$ realidade, esse processo de ajuste técnico-produtivo-gerencial acentuou a propensão para concentrar a indústria paranaense na Região Metropolitana de Curitiba (RMC), esvaziando, em contrapartida, a concentração em outras regiões do Estado. Numa abordagem retrospectiva, as informações sobre a divisão geográfica da indústria estadual apontavam a constituição de dois pólos industriais no interior do Estado na primeira metade dos anos 70, representados pelas regiões de Ponta Grossa e de Londrina. Em 1975, essas duas regiões geraram um valor adicionado equivalente ao da RMC. Entretanto, em meados da década de 90, ambas perderam participação relativa para algumas poucas regiões do Estado, principalmente, para a RMC, cujo avanço foi devido à maturação das inversões da indústria cimenteira, instalação de refinaria de petróleo e ao estabelecimento e consolidação da Cidade Industrial de Curitiba. Quanto à 
disseminação do crescimento industrial no território paranaense, pode-se observar, atualmente, quatro principais pólos no interior do Estado: Ponta Grossa, Londrina, Maringá e Extremo-Oeste que, juntos, contribuíram, em 1994, com 22,1\% para a formação do valor adicionado industrial estadual, contra os 58,3\% da RMC (Lourenço, 1996a).

Diante do rápido crescimento e diversificação da economia estadual, aliados ao processo de descentralização econômica no território brasileiro e, também, incentivado no Paraná, torna-se imprescindíveis conhecer o aprofundamento das relações inter-setoriais, bem como inter-regionais da economia paranaense a fim de priorizar escolhas de estratégias de crescimento. Na realidade, a determinação dos setores com maior potencial de geração de emprego e renda, tem sido tarefa difícil dos planejadores de investimentos, tanto públicos quanto privados. Além disso, os recursos são limitados e, portanto, os investimentos têm que apresentar altos retornos em termos de custos e beneficios, além de propagar efeitos no sistema produtivo e conferir dinamismo à economia.

De fato, muitos projetos de investimento excedem o montante de recursos disponíveis e a questão, que se coloca é de como escolher os que poderão gerar maior contribuição para o crescimento e desenvolvimento. Assim, pode-se indagar: considerando as diversas regiões-pólo do Estado, que setores na economia paranaense são importantes na geração de emprego e renda? Que setores sobressaem na geração de efeitos propulsores sobre os demais? Quais deles podem propiciar um maior crescimento econômico e, com políticas direcionadas, atingir o desenvolvimento econômico? Como são as relações inter-setoriais entre as regiões-pólo da economia paranaense? Este trabalho é uma tentativa de buscar respostas claras para essas questões.

\subsection{Objetivos}

O objetivo principal desta tese é identificar os principais pólos da economia paranaense, os setores com maior potencial de geração de emprego e renda e suas inter- 
relações, com base na matriz de insumo-produto do Estado do Paraná referente ao ano de 1995. Especificamente, pretende-se:

. construir a matriz de insumo-produto inter-regional para o Paraná;

. determinar os setores com maior poder de encadeamento na economia paranaense e em cada região-pólo;

. estimar o impacto da demanda final de forma a identificar os setores e as regiões-pólo mais importantes para o incremento da economia paranaense;

- comparar a estrutura produtiva de cada pólo regional com a paranaense e . identificar as interações sinergéticas entre as regiões-pólo. 


\section{TRANSFORMAÇÕES DA ESTRUTURA PRODUTIVA PARANAENSE: DA OCUPAÇÃO AOS ANOS 90}

O presente capítulo tem por objetivo fazer uma análise histórica da evolução da estrutura produtiva da economia paranaense, desde a sua ocupação até os anos 90 . A compreensão do desenvolvimento da economia ao longo do tempo permitirá o entendimento da conformação dos diversos pólos produtivos na economia estadual, subsidiando a análise proposta neste trabalho.

\subsection{Ocupação inicial do território}

O início da ocupação de parte do território paranaense é tão antiga quanto o descobrimento do Brasil. Em 1549, já havia indicação de portugueses na região litorânea do Paraná, os quais dedicavam-se ao tráfico de índios e serviam de interpretes ou de guias às esquadras que se dirigiam ao rio da Prata ou ao Pacífico (Martins citado por Padis, 1981).

Embora, haja essa indicação do início da ocupação do território paranaense, na realidade, somente a partir do princípio da segunda metade do século XVI, com a vinda dos espanhóis, é que começou efetivamente a sua ocupação. Naquela época, o governador do Paraguai resolveu fundar várias vilas no território paraguaio, notadamente na região de Guaíra, que hoje pertence ao Paraná, com a finalidade de subordinar cerca de 200.000 índios que viviam na região e deter a penetração portuguesa. No entanto, os constantes conflitos com os índios e o desinteresse da Espanha pela região, considerada de importância secundária no seu império americano, 
levou o governo espanhol a confiar o problema da pacificação dos índios aos jesuitas, os quais, em 1609 criaram a Província Jesuítica do Paraguai.

Segundo Lugon, citado por Magalhães Filho (1996), em poucos anos haviam sido fundadas 13 reduções ${ }^{1}$ entre o rio Paraná e o Tibagi. Esta foi a primeira experiência de um sistema de agricultura comunal, baseada na propriedade coletiva da terra e da produção.

A tentativa dos jesuítas de catequizar os índios, no Paraná, não obteve sucesso e, por volta de 1628/32, estava completamente fracassada. Isso ocorreu fundamentalmente devido à necessidade de mão-de-obra para a lavoura em outras regiões do país, especialmente nas atividades açúcareiras do Nordeste. Nessa época, a captura de nativos pelos bandeirantes era economicamente compensatória, pois eles alcançavam bons preços no mercado paulista. Além disso, a captura de índios aldeados implicava em vantagens financeiras maiores, pois estes possuíam alguma instrução e certo conhecimento de algum oficio.

Na verdade, a ação paulista no território paranaense teve significado muito maior do que a simples captura de nativos. De fato, como salienta Padis (1981, p. 17), “a expulsão dos jesuítas e a destruição dos núcleos por eles constituídos, significaram uma vitória dos portugueses sobre os espanhóis, na luta pela posse do território". Com esta ação, não restou nenhum núcleo de população branca em nenhuma parte do território paranaense. Somente no final da primeira metade do século XVII, atraídos pela exploração do ouro, surgiram as primeiras povoações no litoral, notadamente Paranaguá, Antonina e Morretes.

As penetrações na busca pelo ouro continuaram, com os mineradores transpondo a Serra do Mar criando caminhos de ligação do litoral com o primeiro planalto $^{2}$. À medida que estas penetrações iam-se consolidando e que novas minas eram descobertas, novos núcleos populacionais iam surgindo. Assim, na década de noventa do

\footnotetext{
${ }^{1}$ Aldeias de índios catequizados sob a administração de padres.

${ }^{2}$ Devido às suas características geográficas, o Estado do Paraná divide-se em três planaltos: o primeiro compreende a região de Curitiba; o segundo o de Ponta Grossa e o terceiro, o restante do Estado.
} 
século XVII, algumas cidades, no primeiro planalto, se consolidam, com destaque para Curitiba, São José dos Pinhais, Bocaiúva do Sul, entre outras.

\subsection{Ciclo do ouro}

O ciclo do ouro no território paranaense durou poucas décadas. Seu apogeu ocorreu no período de 1691 a 1700, quando a produção teria superado duas toneladas por ano (Carmo, 1981).

A atividade mineradora propiciou o desenvolvimento de outras atividades econômicas como a pequena agricultura e as manufatureiras de baixo padrão, já que as mais sofisticadas eram importadas. A função principal da agricultura era abastecer os centros populacionais emergentes naquela época. Assim, quando o ouro se esgotou, a ocupação permaneceu baseada numa agricultura de subsistência, tendo o trigo como o principal produto.

A base econômica da mineração aurífera era o escravagismo. Com a decadência da atividade, este deixou de ter importância e apenas alguns poucos escravos ainda foram mantidos pelos sesmeiros (detentores de terras cedidas pelas sesmarias), principalmente, para o transporte de mercadorias entre o planalto e o litoral. Por outro lado, não eram mais necessários para a atividade de subsistência porque não havia condições de adquiri-los.

Essa inexpressiva economia de subsistência perdurou por quase meio século, concentrada no planalto e ligada ao litoral por caminhos precários, ficando inteiramente isolada e à margem da evolução da economia colonial (Magalhães Filho, 1996).

Por fim, atribui-se ao ciclo do ouro, como salienta Carmo (1981), o princípio da ocupação do território paranaense, bem como a formação de pequenos núcleos urbanos que, após o declínio da exploração mineral, passam a dedicar-se mais à economia de subsistência, sobrevivendo para prosseguir em novos ciclos. 


\subsection{Tropeirismo}

O período da história paranaense denominado de Tropeirismo teve grande importância na ocupação e na fixação de núcleos urbanos no interior do Estado.

A descoberta das minas de ouro, em Minas Gerais, no final do século XVII, propiciou novo estímulo à economia paranaense. $\mathrm{O}$ principal problema enfrentado pela região produtora era o transporte, pois o único meio para as cargas importadas e exportadas, no trajeto porto do Rio de Janeiro à região aurífera, era o lombo de animais, principalmente muares. Em função do crescimento da produção do ouro, cresceu a necessidade de animais e coube à região Extremo Sul do país responder a esta demanda.

O caminho percorrido pelos tropeiros ligava o Rio Grande do Sul a Sorocaba, São Paulo, onde se realizavam as feiras de animais. Esse trajeto atravessava os campos de Vacaria (RS), Lajes (SC) e Curitiba, que passaram a ser utilizados como invernadas, para recuperação de animais após as longas marchas a que eram submetidos. Essa nova atividade veio, sem dúvida, despertar as regiões de planaltos no Estado. Abriu, dessa forma, uma nova fonte de lucro, já que, até então, os fatores de produção eram subutilizados. Assim, a pecuária se constituiria numa atividade produtiva predominante e as pessoas que detinham certo montante de capital passaram a adquirir animais no Sul para revendê-los em Sorocaba. Com essa nova prática, surgiu a figura do tropeiro, intermediário entre os criadores do Sul e os compradores das feiras. Essa nova atividade econômica propiciou a construção de pousadas e a produção de alimentos, muitos dos quais exportados junto com as tropas.

O reflexo da atividade tropeirista foi a ampliação da ocupação do território paranaense. Ao longo das rotas percorridas pelos tropeiros surgiram lugarejos que, posteriormente, transformaram-se em vilas que hoje, são cidades, como, por exemplo, Lapa, Jaguariaíva, Castro, Ponta Grossa e Palmeira.

No decorrer da fase de prosperidade aurífera brasileira, a economia paranaense manteve-se em crescimento. Assim, conforme ressalta Magalhães Filho (1996, p. 135) 
"o proprietário de terras, que era simultaneamente tropeiro, representava a classe dominante. Em suas mãos acumulava-se a renda, diversificando-se e refinando-se seus hábitos de consumo, pelo que aumentavam as importações, pagas com o excedente gerado pelo comércio e a criação de animais".

Nesse sentido, é importante salientar que, apesar de a atividade ter gerado incremento da renda interna paranaense, a estrutura da atividade interna manufatureira pouco se alterou em relação ao ciclo do ouro, tendo em vista que as classes de renda mais elevada importavam do exterior os bens de consumo imediatos e duráveis, em detrimento da produção local.

Cabe, ainda, ressaltar que nem todos os tropeiros eram proprietários de terras. Muitos limitavam-se a comprar animais no Sul para vendê-los em qualquer ponto ao longo do trajeto ou mesmo no ponto final do percurso, em Sorocaba. Para isso, pagavam aluguel pelas terras de invernadas. Por outro lado, muitos proprietários de terras limitavam-se a alugar suas propriedades às tropas alheias, não exercendo, portanto, a atividade tropeirista.

A decadência da economia do ouro, no Brasil, no último quartel do século XVIII, restringiu o mercado interno, causando uma redução da demanda e, conseqüentemente, do tropeirismo. $\mathrm{O}$ efeito foi a estagnação da economia paranaense. A agricultura de subsistência passou a ser, novamente, a atividade principal, mas com bases territoriais maiores do que as do ciclo do ouro. Nesse momento, não só o litoral e o primeiro planalto, mas, também, o segundo planalto, estavam inteiramente ocupados, ainda que com baixíssima densidade (Magalhães Filho, 1996).

O fim do tropeirismo deu-se com a construção de estradas de ferro na região Centro-Sul do país, o que reduziu sensivelmente a demanda por animais de carga. Contudo, a ligação entre o Centro-Sul e a economia paranaense nunca mais desapareceria, já que as exportações de animais, as de pequenos excedentes agrícolas, juntamente com as de objetos de couro e madeira, mantiveram aberta uma rota durante a recessão seguinte à crise do ouro e após o desaparecimento do tropeirismo. Apesar do fim do tropeirismo, o impacto na renda interna paranaense não se fez sentir como no 
ciclo do ouro, pois outra atividade econômica já vinha sendo desenvolvida e veio a constituir o novo ciclo de atividade da economia estadual: a extração da erva-mate.

\subsection{Ciclo da erva-mate}

Apesar de o mate ser explorado para consumo interno, desde o início da colonização do território paranaense, sua importância econômica manifestou-se quando surgiu a possibilidade de exportação para os mercados argentino, uruguaio e chileno. Tradicionalmente, o Paraguai, até os primeiros anos do século XIX, era o principal fornecedor de mate para esses mercados. No entanto, quando o governo paraguaio, em 1813, proibiu a exportação, a fim de atender à demanda interna, provocou, com este ato, o aumento das exportações paranaenses pois, Argentina e Uruguai, voltaram-se para o mercado brasileiro. Assim, em 1815 e 1821, com a instalação dos dois primeiros engenhos em Paranaguá, cresceu a produção do mate no Paraná.

Aos poucos, mas de forma consistente, a exportação vai-se consolidando no Estado, bem como nos demais estados do Sul, Santa Catarina e Rio Grande do Sul. A alta crescente dos preços do produto exportado, no período 1833-36, interferiu direta e indiretamente na economia da região no sentido de aumentar significativamente a produção interna. No entanto, a crise européia, a Guerra dos Farrapos e a desorganização das economias platinas em função da crise européia, levaram a uma sensível redução no valor e nas quantidades exportadas até o final dos anos 30. A recuperação das economias dos países platinos e a revogação da proibição das exportações do mate pelo Paraguai, tornaram a situação ainda mais complicada para a atividade ervateira paranaense.

Após um longo periodo de crise, a reação nas exportações de erva-mate voltou a se manifestar a partir da segunda metade do século XIX. Entre 1852 e 1860, os preços correntes e as exportações multiplicaram-se quase 2,5 vezes (Padis, 1981). A dificuldade em ampliar o mercado externo estava na qualidade inferior do produto paranaense, geralmente provocada por fraude na produção que consistia na adição de folhas de outras plantas e gravetos. Para tentar corrigir esse problema, o presidente provincial baixou um regulamento severo, que fixava o período de colheita, formas de 
tratamento e acondicionamento de ervas, bem como proibia a mistura de elementos estranhos. $\mathrm{O}$ regulamento previa multas severas aos infratores, embora a eficácia de tais regras tenha sido discutível, basicamente em função da deficiência da máquina administrativa e repressiva.

Em 1855, com o objetivo de desenvolver a atividade ervateira, o governo determinou a construção da "Estrada da Graciosa", melhorando a ligação entre a capital e o litoral. Com a estrada, ocorreu a transferência dos engenhos de beneficiamento de mate do litoral para o planalto os quais passaram a se localizar na mesma área dos ervais.

A recuperação dos preços internacionais do mate, a partir de 1866, deu novo impulso à atividade ervateira. A causa principal da mudança de comportamento dos preços foi a Guerra do Paraguai (1864-70) que desorganizou a economia desse país. Até o final da guerra, conforme salienta Padis (1981), a exportação do produto paranaense duplicou, passando de 7 mil toneladas para mais de 14 mil, atingindo 16,5 mil toneladas no ano de 1872.

Após um pequeno período de declínio na atividade ervateira do Estado, as quantidades exportadas apresentaram um incremento em mais de $30 \%$ no decênio 1882 92. Contudo, a última década do século XIX, registrou níveis muito baixos nas quantidades exportadas, jamais atingidos nas três décadas anteriores. Dentre os fatores que explicam essa queda das exportações pode-se mencionar a abolição da escravatura, a proclamação da República e a crise política e econômica do pós proclamação, os quais interferiram, de forma acentuada, em toda a economia brasileira. Além disso, a guerra civil do Uruguai, que era um dos principais importadores, e a crise européia deprimiram as exportações das repúblicas do Prata, reduzindo, evidentemente, a capacidade de importação desses países.

No qüinqüênio 1897-1902, ocorreu uma forte recuperação das exportações, tanto que o mate chegou a contribuir com $98 \%$ do total da exportação estadual e com $40 \%$ da arrecadação global de impostos (Padis, 1981). A partir do início do presente século, até os anos 30, a participação relativa do mate no valor das exportações apresentou uma tendência declinante, apesar de a quantidade exportada ter aumentado. 
Isso pode ser explicado pelo incremento da exportação do produto não beneficiado, cujo valor decrescia sensivelmente, em função da menor densidade de trabalho, por unidade produzida.

A partir da crise de 29, a economia ervateira entra em declínio. Na verdade, como ressalta Padis (1981, p. 63), após 1931

"começa no Paraná a liquidação da economia ervateira e, com esta, as previsões orçamentarias (o mate havia se constituido longamente na principal fonte de receita) principiam a fracassar. $O$ governo estadual, extremamente preocupado, tenta, a partir de 1932, incrementar as exportações, reduzindo em 20 por cento as taxas sobre o produto".

Contudo, tais medidas não foram suficientes para recuperar a atividade e nem aumentar o consumo interno.

Por fim, vale ressaltar que, a partir da metade da segunda década deste século, a economia ervateira foi, aos pouco, perdendo a condição de atividade condutora da economia, dando lugar a uma participação cada vez maior do café. Para Padis (1981), por se tratar de uma atividade extrativa e itinerante, a economia ervateira não contribuiu em quase nada para a urbanização do Estado já que as economias externas por ela geradas, eram sensivelmente pequenas em função de sua baixa e irregular rentabilidade econômica.

\subsection{Ciclo da madeira}

A extração de madeira, apesar de importante para o sistema econômico paranaense, nunca chegou a ser uma atividade importante da economia local, a exemplo do mate. Desde os primórdios da colonização, as imensas matas nativas de araucária, nos planaltos paranaenses, eram utilizadas para a produção de artigos de madeira destinados ao mercado local. No entanto, a expansão da atividade madeireira passou a ter importância econômica a partir do momento que começou atender a demanda externa. No final do século passado, surgiram perspectivas de desenvolvimento da 
atividade devido aos estímulos advindos, de um lado, do crescimento da economia brasileira, graças ao café e, de outro, da rápida expansão da economia argentina, resultante da crescente demanda européia por carnes, trigo, lã e linho (Magalhães Filho, 1996).

O grande obstáculo ao desenvolvimento da atividade madeireira no Estado era a inexistência de um sistema eficiente de transporte, o que encarecia demasiadamente o produto, tornando-o anti-competitivo frente aos concorrentes filandeses e canadenses. Com efeito, somando todos os custos, o preço do pinho do Paraná era mais elevado do que o da maioria das madeiras importadas (Padis, 1981). Além disso, o pinheiro paranaense era de má qualidade, devido à carência, basicamente, de cuidados técnicos, já que não havia critério para a escolha das árvores a serem abatidas, nem tão pouco, para a idade ideal das mesmas, o que provocava rápida deterioração da madeira dada a exposição às intempéries.

$\mathrm{O}$ incremento das exportações de madeira paranaense para o mercado platino e outras regiões do país só veio ocorrer após a inauguração da estrada de ferro CuritibaParanaguá, em 1886. Outro empreendimento que ajudou as exportações de madeira, em escala significativa, foi a ligação do Paraná ao Centro-Sul do Brasil quando da conclusão, em 1906, da ferrovia São Paulo-Rio Grande do Sul. Além disso, com o advento da Primeira Guerra Mundial, houve uma redução significativa das importações brasileiras de madeira européia, estimulando fortemente o desenvolvimento do setor. Magalhães Filho (1996, p. 141), observa que foi devido a essa "perturbação temporária das condições de intercâmbio comercial, causada pela guerra, que a madeira paranaense conseguiu firmar-se definitivamente, tanto no mercado interno quanto no platino".

A participação relativa das exportações paranaenses de madeira teve seu auge em 1943, quando atingiu 49,5\% do total das exportações do Estado. Contudo, a partir dessa data, observou-se uma perda relativa na composição das exportações estadual, talvez nem tanto pela redução das exportações de madeira, mas sim, pela inclusão de outros artigos na pauta de exportação (Carmo, 1981).

O setor madeireiro desempenha, atualmente, um importante papel na economia estadual, apesar do declínio das reservas florestais. No entanto, é preciso 
ressaltar a mudança conceitual na transformação do setor, em que o papel, a celulose e os produtos de tecnologias mais avançadas, como os aglomerados, certamente terão um peso maior do que o beneficiamento e exportação primário do produto.

\subsection{Ciclo do café}

As primeiras plantações de café no território paranaense datam de meados do século XIX e, por um longo período, a produção nunca chegou a ter significado econômico. No entanto, por volta de 1865 , a cafeicultura paulista já se aproximava dos limites geográficos do Estado. $\mathrm{O}$ vale do Itararé foi a porta de entrada para a exploração comercial da cafeicultura no Paraná, cuja expansão da produção se deu após o Convênio de Taubaté ${ }^{3}$, em 1906, quando o governo paulista adotou medidas restritivas à produção. A saída para os fazendeiros paulistas foi a transferência para o Paraná, onde não havia limitações para o plantio de novos cafezais.

Nesse sentido, embora o Paraná não tenha assinado o convênio, a ocupação da região Norte Paranaense processou-se lentamente durante as duas primeiras décadas do atual século para, a partir de 1920, tomar um grande impulso. Para Padis (1981), o rápido aumento do preço internacional do café, após o fim da Primeira Guerra, foi o principal fator de estímulo aos agricultores. Por outro lado, as regiões cafeeiras tradicionais de São Paulo não tinham condições de atender à crescente demanda externa em função, basicamente, de problemas sanitários e de esgotamento do solo. A excepcional qualidade do solo paranaense e as condições climáticas favoráveis permitiram alcançar altos índices de produtividade que compensavam os custos dos transportes, além de atrair um intenso fluxo migratório paulista, mineiro e, até, nordestinos.

Até o final dos anos 40, a participação da produção paranaense era relativamente pequena. $O$ grande impulso ocorreu, a partir da safra 1947-48, quando o Paraná chegou a ser responsável por $11,1 \%$ da produção nacional. O Estado iníciou a ${ }^{3}$ O referido convênio, celebrado na cidade de Taubaté - SP, em fevereiro de 1906, definiu as bases do que
se convencionou chamar de política de "valorização" do café. Para mais detalhes ver Furtado, 1977, p.179. 
década de 50 com cerca de um quarto da produção nacional e, tornou-se o principal produtor no final da década. $O$ auge ocorreu nos anos 60, quando, na safra $1962 / 63$, o Paraná gerou 62,8\% da produção brasileira (Padis, 1981).

A supremacia da cafeicultura paranaense deixou de existir, a partir dos anos 70, especialmente em 1975, quando ocorreu uma forte geada, dizimando, praticamente, todo o parque cafeeiro estadual. Os anos 70 marcam, também, o aprofundamento da transformação da agricultura paranaense com a intensificação do uso de insumos modernos e da mecanização na agricultura, resultando num processo de substituição de culturas. Nesse sentido, o café sai de cena e a soja ganha grande impulso, transformando-se no produto condutor da agricultura estadual.

Apesar de o Paraná ter sido o principal produtor nacional de café, o fato é que, parte ponderável de sua renda contribuiu para subsidiar o parque industrial paulista e atenuar os déficits orçamentários da União. Não obstante, Carmo (1981, p. 53), salientou que

"regionalmente, em torno da atividade condutora, passou a se desenvolver um setor terciário e secundário, inicialmente agroindustrial de beneficiamento, posteriormente para agroindustriais mais complexas, inclusive em função da diversificação da cultura cafeeira. Outros ramos industriais de peso na renda regional, que se desenvolveram, foram tipicos para atendimento de certos tipos de demanda regional e não estadual ou nacional".

A título de exemplificação, podem-se citar os ramos da construção civil, já que os produtos manufaturados mais complexos provinham do centro dinâmico da economia brasileira, São Paulo.

Por fim, é importante salientar que, embora parte da renda tenha sido canalizada para atividade fora do Estado, a cafeicultura propiciou uma ocupação veloz do território paranaense, bem como permitiu uma rápida e profunda transformação na estrutura produtiva da economia estadual. 


\subsection{Estrutura produtiva antes dos anos 70}

Como foi visto anteriormente, o café foi o principal responsável pela geração de renda na economia paranaense. No entanto, parte significativa desta renda era canalizada para investimentos na região industrial do país, em detrimento das inversões internas em outros ramos da estrutura produtiva local. De fato, a expansão da atividade cafeeira foi tão veloz e surpreendente que não permitiu aos demais ramos de atividade acompanhar seu ritmo, tanto que, no período 1947-59, os setores secundário e terciário perderam significado relativo na composição da renda paranaense, conforme evidencia a Tabela 2.1 e a Figura 2.1. Por outro lado, a participação da renda paranaense na economia brasileira vem apresentando uma tendência crescente ao longo dos anos.

Segundo Padis (1981), a principal causa do carreamento de parte da renda interna gerada no Estado para outras regiões do país foram as vantagens dos investimentos propiciadas pelo setor cafeeiro. Nenhuma outra atividade seria suficientemente rentável para atrair investimentos e, por isso, não houve condições para a diversificação da estrutura produtiva. Portanto,

"a cafeicultura paranaense, no mesmo tempo em que foi a maior responsável pela rápida transformação econômica registrada no Estado, em razão da forma como se desenvolveu e se estruturou, criou barreiras e limitações no aparecimento de outras atividades econômicas, especialmente industriais. Foi assim que, pelos condicionantes históricos criados, os efeitos multiplicadores dos investimentos realizados fizeram-se sentir num sentido: ampliaram ou criaram condições de desenvolvimento às atividades ligadas ou decorrentes de cafeicultura" (Padis, 1981, p. 194).

$\mathrm{Na}$ realidade, pode-se afirmar que o Estado aproveitou pouco o período de crescimento da produção cafeeira para implantar uma infra-estrutura condizente ao ritmo de crescimento de sua economia. Essa situação foi revertida nos anos 60, quando o governo estadual intensificou esforços no sentido de suprimir a deficiência em infraestrutura e, principalmente, procurou criar condições e estímulos para a implantação do 
parque industrial. De fato, de todos os investimentos feitos, a maior parte foi canalizada para rodovias e energia elétrica. Além disso, foram direcionados recursos para a ampliação da rede de armazéns e silos do Estado e para o reaparelhamento dos portos de Antonina e Paranaguá.

Tabela 2.1. Composição relativa da renda interna paranaense, segundo os setores de atividade e a participação no Brasil, 1939 e 1947-1967.

\begin{tabular}{lcccc}
\hline Ano & Agricultura & Indústria & Serviços & Paraná/Brasil \\
\hline 1939 & 48,5 & 14,0 & 37,5 & 3,0 \\
1947 & 47,8 & 13,0 & 39,2 & 3,8 \\
1948 & 48,7 & 13,9 & 37,4 & 4,2 \\
1949 & 47,6 & 15,0 & 37,4 & 4,3 \\
1950 & 51,6 & 13,4 & 35,0 & 4,9 \\
1951 & 49,2 & 12,8 & 38,6 & 4,8 \\
1952 & 52,2 & 12,2 & 35,6 & 5,3 \\
1953 & 52,9 & 11,7 & 35,4 & 5,5 \\
1954 & 48,3 & 14,1 & 37,6 & 4,7 \\
1955 & 55,1 & 11,0 & 33,0 & 5,8 \\
1956 & 44,5 & 13,5 & 42,0 & 4,6 \\
1957 & 48,7 & 11,4 & 39,9 & 5,1 \\
1958 & 51,9 & 10,1 & 38,0 & 3,9 \\
1959 & 55,1 & 10,5 & 34,4 & 6,5 \\
1960 & 54,9 & 9,5 & 35,5 & 6,3 \\
1961 & 52,8 & 9,1 & 38,1 & 6,1 \\
1962 & 55,3 & 9,0 & 35,7 & 6,6 \\
1963 & 46,8 & 12,4 & 40,9 & 5,6 \\
1964 & 46,9 & 12,1 & 41,0 & 5,7 \\
1965 & 50,9 & 9,9 & 39,2 & 6,6 \\
1966 & 41,2 & 12,2 & 46,2 & 6,1 \\
1967 & 44,2 & 10,0 & 45,8 & 5,5 \\
\hline
\end{tabular}

Fonte: Padis (1981), p. 205 e 207.

Com relação aos financiamentos destinados às atividades industriais os setores mais beneficiados foram os de produção de conglomerados de madeira, pasta mecânica e de papel, a indústria de beneficiamento e transformação de produtos de lavoura, especialmente, as indústrias de óleos vegetais e café solúvel, e a indústria de produção animal, notadamente os frigoríficos. 


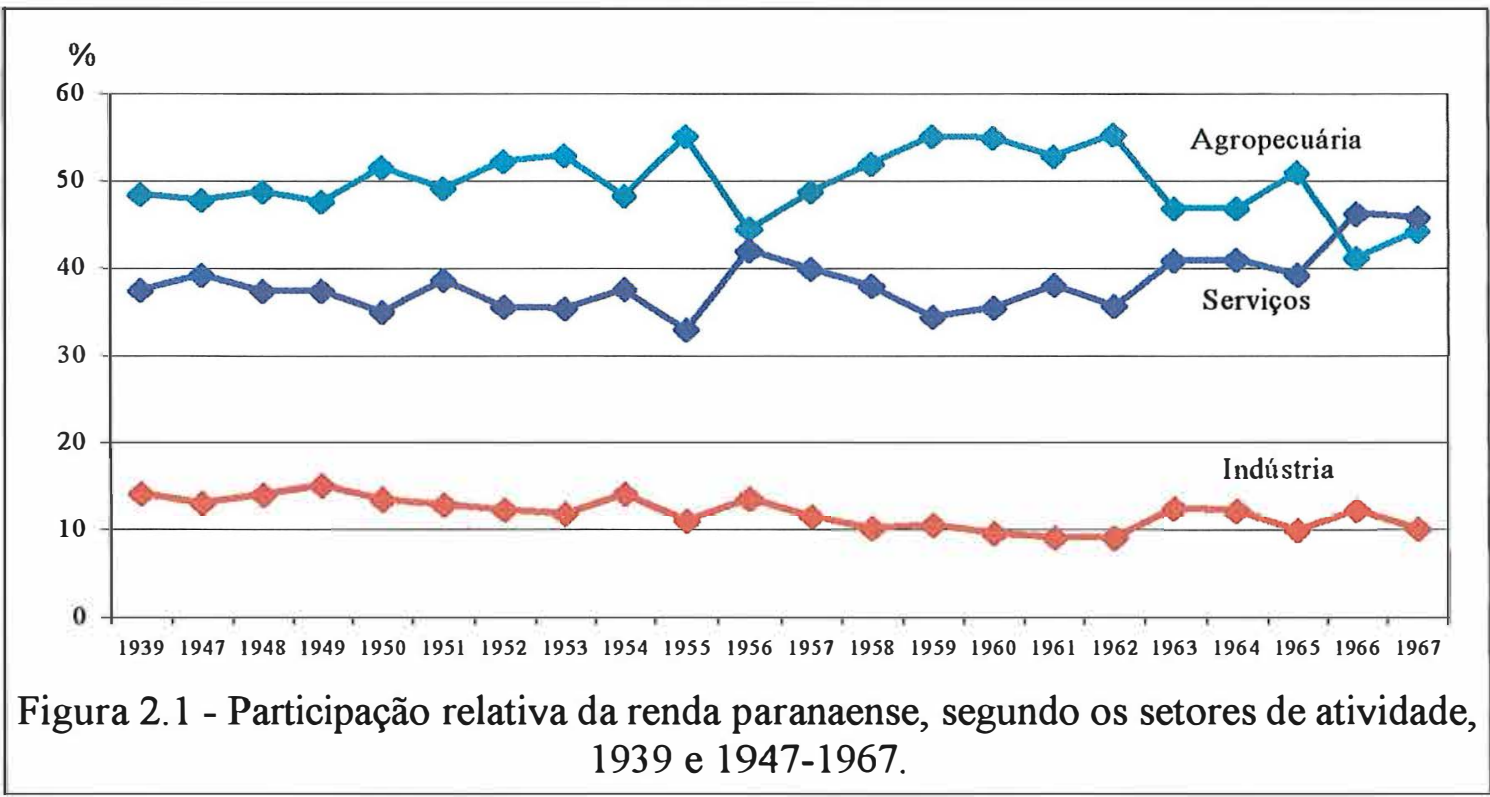

Apesar de todo o esforço do governo estadual no sentido de tentar industrializar a economia paranaense, pelo menos até o final da década de 60, a estrutura produtiva estadual não se alterou, de forma significativa. $\mathrm{O}$ setor primário permaneceu $\mathrm{o}$ principal responsável pela geração da renda interna (Tabela 2.1). As mudanças mais profundas começaram a aparecer após os anos 70, o que será visto no próximo item.

\subsection{Estrutura produtiva na década de 70}

As bases da atual estrutura produtiva paranaense foram iniciadas nos anos 70. Nesse período, ocorreu um aprofundamento da modernização da agricultura e uma ampliação do parque agroindustrial, além do surgimento de outras indústrias desvinculadas destas atividades. Foi também, um período marcado por grandes migrações para fora do Estado.

No tocante à agropecuária, o processo de modernização foi caracterizado pela concentração fundiária ${ }^{4}$, introdução de culturas mecanizadas e grande avanço

\footnotetext{
${ }^{4}$ Para mais detalhes sobre a concentração fundiária no Paraná nos anos 70, ver Silva (1996) e IPARDES (1986).
} 
tecnológico. A transformação na pauta de produtos agrícolas do Estado foi baseada na dobradinha soja e trigo.

De acordo com Rolin (1995), a modernização da agricultura implicou na utilização de insumos modernos oriundos da atividade industrial, como máquinas, trator, implementos agrícolas, sementes melhoradas, esquema sofisticado de comercialização e financiamento, permitindo, dessa maneira, o início de uma mudança qualitativa do tipo de atividade industrial existente no Paraná. A partir de então,

“o dinamismo agropecuário possibilita a expansão de setores processadores de seus produtos, tais como: óleos vegetais, frigorificos, alimentos em geral, madeira, rações, fibras vegetais, etc. Em suma, acoplada à agropecuária, quer fornecendo máquinas e insumos, quer processando sua produção, desenvolve-se a principal vertente da indústria paranaense, diversificando a produção nos gêneros anteriormente existentes bem como implantando novos gêneros industriais" (IPARDES, 1982, p. 51).

A agricultura, cada vez mais, passa a estreitar e ampliar relação com a indústria e com o comércio, deixando de ser, somente, demandante de insumos modernos, máquinas e equipamentos agrícolas, para se tornar, também, fornecedora de matérias-primas industriais, além de alimentos para o abastecimento interno (IPARDES, 1986).

A estrutura industrial intensificou sua diversificação e setores tradicionais como madeira e outros deram lugar a gêneros mais dinâmicos, como os segmentos químico e material elétrico e de comunicações. Essa nova dinâmica permitiu ampliar as relações inter e intra-setores, reforçando o parque industrial paranaense. Conseqüentemente,

"aumenta no Paraná o número de empresas de maior porte, geralmente utilizando tecnologia moderna para elevar seus índices de produtividade. Essa nova performance vai conformando uma estrutura industrial tipicamente oligopolizada, voltada para o mercado nacional e internacional" (IPARDES, 1986, p.3). 
As transformações ocorridas no Estado ao longo dos anos 70 provocaram acelerado crescimento em todos os setores da economia estadual. O Produto Interno Bruto (PIB) do Paraná cresceu a uma taxa média de 18,8\% ao ano no período 1970-74, superior ao crescimento médio de $11,6 \%$ ao ano do Brasil. Nesse mesmo período, os setores agricultura, indústria e comércio, cresceram a uma taxa média anual de $14,5 \%$, $22,9 \%$ e 19,5\%, respectivamente, conforme mostra a Tabela 2.2 .

Tabela 2.2. Taxas médias anuais de crescimento do Produto Interno Bruto, por classes de atividades, no Paraná e Brasil, 1970-1980.

\begin{tabular}{lcccccccc}
\hline \multirow{2}{*}{ Período } & \multicolumn{2}{c}{ Agricultura } & \multicolumn{2}{c}{ Indústria } & \multicolumn{2}{c}{ Comércio } & \multicolumn{2}{c}{ PIB } \\
\cline { 2 - 9 } & PR & BR & PR & BR & PR & BR & PR & BR \\
\hline $1970-74$ & 14,5 & 6,7 & 22,9 & 12,6 & 19,5 & 11,8 & 18,8 & 11,6 \\
$1974-80$ & $-2,4$ & 4,6 & 17,4 & 7,3 & 14,0 & 5,2 & 9,9 & 6,6 \\
\hline
\end{tabular}

Fonte: IPARDES, 1986, p.3.

O forte dinamismo da base produtiva paranaense, aliado às expressivas taxas de crescimento em todas as classes da atividade, elevou a participação do Paraná na renda nacional, que passou de 5,5\%, em 1970, para 6,4\% em 1980. No que se refere à participação das classes de atividades econômicas no PIB do Paraná; a agricultura, apesar de seu crescimento ao longo da década, teve sua participação na composição da renda interna reduzida. A fatia da agricultura decresceu, passando de 25,6\%, em 1970, para 19,4\% em 1980 (Volaco et al., 1991). Nesse particular, o setor agrícola foi ultrapassado pelo setor industrial em 1976, quando o Paraná deixou de ser um Estado eminentemente agrícola, ingressando numa fase industrial com forte tendência a se consolidar nos próximos anos (IPARDES, 1986).

\subsection{Estrutura produtiva na década de 80}

Os anos oitenta têm sido vistos como uma década marcada por crises e instabilidade econômica, as quais impuseram limites ao desempenho e crescimento da estrutura produtiva brasileira e paranaense. No caso do Paraná, duas tendências 
estiveram presentes: na primeira metade da década, a economia estadual cresceu aos níveis da nacional e, na segunda, passou a ter um desempenho superior ao do Brasil.

Dadas as especificidades da base produtiva paranaense, os reflexos da recessão foram sentidos de forma diferenciada, às vezes mais, às vezes menos intensos, sendo o saldo geral um desempenho relativamente melhor. Assim, no cômputo geral, a economia do Paraná teve uma expansão média do PIB durante a década de 80 de 5,6\% ao ano, contra 2,9\% da economia brasileira (IPARDES, 1991).

Segundo Rolin (1995), a recessão ocorrida nas primeiros anos da década não causou grandes prejuízos em função do desempenho favorável da agropecuário e de alguns ramos industriais como o de alimentos e a indústria química, não obstante a profunda crise da indústria da construção civil.

A análise setorial mostra que o agropecuário, apesar da grande instabilidade das políticas econômicas e das profundas alterações nas ações dirigidas ao setor como a redução de crédito e de subsídios, não sofreu danos significativos. A produção de grãos não se ressentiu com as mudanças e continuou no seu ritmo de crescimento. As grandes culturas paranaenses, soja, milho, café, trigo e algodão, permaneceram como as responsáveis pela maior geração de valor na agricultura, com destaque para o trigo, que teve o melhor desempenho no período.

Para Leão (1991), o setor agropecuário continuou com suas características de setor dinâmico e modernizador. A agropecuária consolidou seu processo de organização espacial destacando-se a expansão de terras incorporadas ao cultivo, a intensificação da produção via incrementos da produtividade, distribuição regional por meio da ocupação da última fronteira agrícola e a consolidação das grandes culturas em áreas apropriadas com os médios e grandes produtores respondendo pela maior parte da produção. Vale destacar, ainda, o crescimento da participação de outras atividades, como a cana-deaçúcar, aves e ovos, evidenciando uma maior diversificação da pauta de produção agropecuária. Com isso, o setor perde a característica de grandes ciclos de produção regidos por um produto base.

Com relação ao setor secundário, apesar da crise, os anos 80 foram marcados por avanços significativos na estrutura industrial, indicando que a década não foi 
totalmente perdida, como se costuma apregoar. A dinâmica do setor industrial está, intimamente, ligada aos segmentos mais modernos da economia. Assim, observa-se forte dinamismo nos gêneros material elétrico e de comunicações, mecânica, papel e papelão, química e material de transporte. Além desses segmentos industriais, um segundo grupo de indústrias de peso no Estado, teve seu impulso ligado às inversões que objetivavam as exportações e a demanda interna e, especialmente, a um processo de redefinição e reordenação do seu aparelho produtivo e de seus mercados (Leão, 1991).

Os segmentos carne, principalmente aves e carne industrializada, café solúvel, óleos vegetais, laticínios e fiação apresentaram uma estrutura bastante diferenciada, em termos qualitativos, no final dos anos 80 , com destaque para a criação de novos produtos, concentração e diversificação da plantas.

A composição do PIB paranaense, segundo as classes de atividade, está representada na Tabela 2.3 e ilustrada na Figura 2.2. Observa-se uma tendência declinante da agropecuária, notadamente, a partir de 1985. No início dos anos 80, a agropecuária participava com cerca de $20 \%$ na composição do PIB paranaense, tendo caído para cerca de $14 \%$ na final da década. Por outro lado, o setor secundário não apresentou grandes mudanças ao longo dos anos, enquanto o setor terciário teve sua participação aumentada de $51,7 \%$ para $59,7 \%$ no início e final do período, respectivamente.

\subsection{Estrutura produtiva na década de 90}

Os anos 90 iniciaram-se com uma profunda recessão na economia brasileira e paranaense, resultante do encurtamento de liquidez implementada pelo Governo Collor e a subsequente equipe econômica. $\mathrm{O}$ objetivo da política imposta era eliminar as pressões inflacionárias via aperto monetário, contenção fiscal, atrasos tarifários e cambiais e arrocho salarial. $O$ reflexo das políticas adotadas foi um declínio de $4,6 \%$ do PIB brasileiro no primeiro ano da década, comandado pelo setor industrial, cuja queda do nível de atividade chegou a $8,6 \%$. 
Tabela 2.3. Participação percentual das classes de atividade no PIB, a custo de fatores, Paraná, 1980-95.

\begin{tabular}{lccc}
\hline Anos & Agropecuária & Indústria & Serviços \\
\hline 1980 & 19,43 & 28,81 & 51,76 \\
1981 & 20,48 & 29,96 & 49,56 \\
1982 & 17,04 & 28,38 & 54,58 \\
1983 & 17,83 & 28,91 & 53,26 \\
1984 & 19,81 & 26,88 & 53,31 \\
1985 & 20,78 & 25,39 & 53,83 \\
1986 & 18,08 & 25,23 & 56,69 \\
1987 & 16,80 & 24,79 & 58,41 \\
1988 & 14,26 & 27,06 & 58,68 \\
1989 & 13,97 & 26,31 & 59,72 \\
1990 & 14,66 & 31,60 & 53,74 \\
1991 & 12,57 & 32,24 & 55,19 \\
1992 & 12,61 & 31,28 & 57,11 \\
1993 & 11,99 & 31,56 & 56,46 \\
1994 & 14,14 & 29,98 & 55,88 \\
1995 & 13,78 & 30,71 & 55,51 \\
\hline
\end{tabular}

Fonte: Volaco et al., 1991, p. 6 (1980 a 1989); IPARDES, 1997a (1990 a 1994) e IPARDES, 1998 (1995).

No Paraná, os efeitos da conjuntura recessiva foram mais significativos, devido ao predomínio da agropecuária e da agroindústria na estrutura produtiva do Estado, resultando numa retração de 6,6\% do PIB (Volaco et al., 1991). A queda do PIB agropecuário foi de $9,7 \%$, enquanto o da indústria retraiu 4,8\%. O declínio foi praticamente generalizado, com quedas significativas nos segmentos vinculados à agropecuária e nos ramos fornecedores da construção civil. A exceção ficou com os gêneros mecânica, material de transporte e papel e papelão.

O processo de retração da economia, tanto brasileira quanto paranaense, a partir do início de 1991, intensificou-se devido à terapia de controle da inflação, que combinava arrocho salarial, juros reais elevados e contenção fiscal. Apesar da profunda crise recessiva nos dois primeiros anos da década, com forte retração em muitos segmentos da atividade produtiva paranaense, o PIB estadual cresceu a uma taxa anual de $4,1 \%$ no período 1990-93, contra 1,4\% registrado para o Brasil (Lourenço, 1994). 


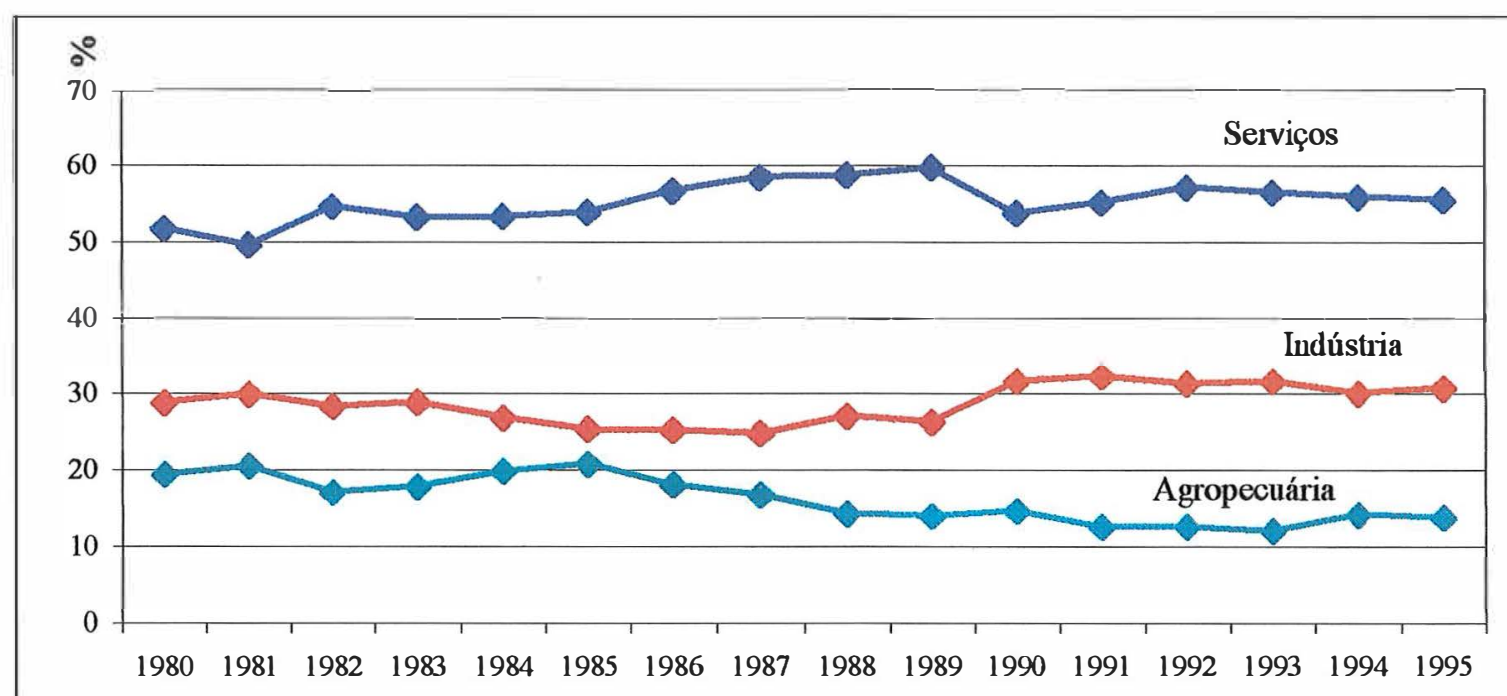

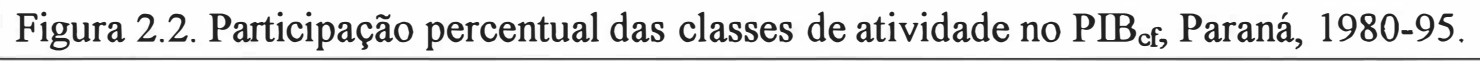

Em 1994, o PIB do Estado cresceu a uma taxa superior à média nacional, $6,6 \%$ contra $5,7 \%$, decorrente do excelente desempenho da indústria estadual que apresentou um crescimento de 9,2\%. Este comportamento sofreu alguma influencia do setor público paranaense, mediante a realização de investimentos em infra-estrutura. Para Lourenço (1995), o rápido crescimento da economia estadual pode ser imputado, em grande medida, a fatores transitórios e estes podem desaparecer de forma tão rápida e surpreendente como surgiram.

Durante os anos de 1993 e 1994, a expansão do PIB estadual foi liderada pelo crescimento da renda do setor primário e seus efeitos multiplicadores para frente e para trás, notadamente no setor de fabricação e venda de insumos, máquinas e implementos, no comércio interno e externo, no mercado de imóveis e bens duráveis e nos transportes rodoviário e ferroviário. Cabe salientar que a integração comercial do Brasil com os demais países integrantes do Mercosul contribuiu significativamente para o desempenho favorável no referido período. Nesse particular, Wosch (1996), mostra que as exportações paranaenses cresceram de US\$1,807 bilhões em 1991 para US\$ 3,567 bilhões em 1995, o que representa um incremento de 97,4\% no período. Tal performance elevou a contribuição relativa do Paraná nas vendas externas brasileiras de 5,7\%, em 1991, para 7,7\% em 1995. Em termos regionais, as exportações paranaenses 
para o Mercosul saltaram de 4,1\% para 14,9\%, em 1990 e 1993, respectivamente. Cumpre ressaltar que essa tendência ascendente não se manteve nos anos de 1994 e 1995. As exportações apresentaram um declínio, estabilizando-se em torno de $10 \%$. Tal fato sugere, por um lado, que outros Estados brasileiros conquistaram fatia desse importante mercado, em detrimento da participação paranaense e, por outro, que o fator localização geográfica, indiscutivelmente importante, não se caracteriza como condição determinante para acentuar o intercâmbio comercial (IPARDES, 1997b).

A abertura comercial ampliou o grau de exposição dos produtos nacionais à concorrência internacional provocando uma reestruturação no sistema produtivo. Nesse sentido, muitos ajustes foram feitos na direção de rápida melhoria dos padrões de eficiência, produtividade, controle de qualidade, treinamento de mão-de-obra, racionalização das linhas de produção, modernização tecnológica e implantação de novas e modernas técnicas de administração e gestão. No caso específico do Paraná, os grandes ajustes recairam mais sobre os gêneros industriais metalurgia, mecânica, material elétrico e de comunicações, material de transporte, química, produtos alimentares, bebidas e vestuário.

Finalmente, a indústria paranaense fechou o ano de 1995 registrando um nível de produção inferior ao do ano anterior, configurando uma autêntica inversão da tendência crescente iniciada em 1993. Do ponto de vista quantitativo, segundo Lourenço (1996a), o exercício de 1995 marcou uma forte retração no desempenho do parque manufatureiro estadual, contabilizando um declínio de 5,6\% contra uma expansão de $1,7 \%$ da indústria brasileira. A referida queda da produção industrial pode ser explicada pela conjunção da instabilidade agrícola e suas repercussões multiplicadoras dinâmicas para frente e para trás, política de juros altos, sobre valorização do real e do esfriamento dos fluxos comerciais e de investimentos entre o Brasil e os países do Mercosul, especialmente com a Argentina, em face da forte contração econômica induzida pelo governo Menen após sua reeleição. 


\subsection{Distribuição espacial do Produto Interno Bruto paranaense}

A distribuição geográfica do PIB paranaense, para o ano de 1995, evidencia que quatro microrregiões homogêneas (MRH) concentram 62,58\% de toda a produção estadual (Tabela 2.4). Somente a MRH de Curitiba respondeu por $36,10 \%$ do PIB, constituindo-se, desta forma, na principal região produtora de bens e serviços da economia paranaense. Praticamente metade da produção do setor secundário e pouco mais de um terço dos serviços gerados no Estado provêm dessa microrregião, sendo a produção do setor primário inexpressiva, cerca de 3\% da agropecuária estadual.

Tabela 2.4. Distribuição espacial do Produto Interno Bruto a custo de fatores, por MRH e ramos de atividade econômica, Paraná, 1995.

\begin{tabular}{lrrrr}
\hline Microrregiões & $\begin{array}{r}\text { Agropecuária } \\
\text { Homogêneas }\end{array}$ & $\begin{array}{r}\text { Indústria } \\
\text { (\%/total) }\end{array}$ & $\begin{array}{r}\text { Serviços } \\
\text { (\%/total) }\end{array}$ & $\begin{array}{r}\text { PIB } \\
\text { (\%) }\end{array}$ \\
\hline Curitiba & 2,90 & 49,96 & 36,68 & 36,10 \\
Litoral Paranaense & 0,32 & 1,19 & 2,11 & 1,58 \\
Alto Ribeira & 0,22 & 0,15 & 0,16 & 0,17 \\
Alto Rio Negro Paranaense & 0,60 & 0,15 & 0,24 & 0,26 \\
Campos de Lapa & 2,76 & 1,39 & 1,16 & 1,45 \\
Campos de Ponta Grossa & 6,51 & 7,14 & 5,17 & 5,96 \\
Campos de Jaguariaiva & 1,31 & 2,82 & 0,87 & 1,53 \\
São Mateus do Sul & 0,76 & 0,59 & 0,44 & 0,53 \\
Colonial de Irati & 2,08 & 0,87 & 1,14 & 1,19 \\
Alto Ivai & 0,87 & 0,22 & 0,45 & 0,44 \\
Norte Velho de Wenceslau Braz & 1,89 & 0,52 & 0,98 & 0,96 \\
Norte Velho de Jacarezinho & 5,38 & 1,79 & 2,79 & 2,84 \\
Algodoeira de Assai & 1,46 & 0,39 & 0,60 & 0,65 \\
Norte Novo de Londrina & 9,13 & 8,51 & 9,55 & 9,17 \\
Norte Novo de Maringá & 4,09 & 3,57 & 5,15 & 4,52 \\
Norte Novíssimo de Paranavaí & 4,39 & 1,24 & 2,10 & 2,15 \\
Norte Novo de Apucarana & 3,49 & 2,00 & 2,34 & 2,40 \\
Norte Novissimo de Umuarama & 6,45 & 2,22 & 3,18 & 3,34 \\
Campo Mourão & 8,89 & 1,71 & 3,50 & 3,70 \\
Pitanga & 1,28 & 0,30 & 0,71 & 0,66 \\
Extremo-Oeste Paranaense & 19,87 & 6,57 & 11,88 & 11,35 \\
Sudoeste Paranaense & 7,51 & 2,56 & 4,16 & 4,13 \\
Campos de Guarapuava & 5,61 & 2,42 & 3,05 & 3,21 \\
Médio Iguaçu & 2,19 & 1,71 & 1,58 & 1,70 \\
\hline TOTAL & 100,0 & 100,0 & 100,0 & 100,0 \\
\hline Fonte: IPARDES & & & &
\end{tabular}

Fonte: IPARDES (1998). 
A MRH Extremo-Oeste Paranaense constitui a segunda mais importante, cuja produção agregada foi de $11,35 \%$ do PIB estadual. Essa performance advém da forte participação do setor agropecuário na economia local, o qual respondeu por, aproximadamente, um quinto da produção do setor primário da economia paranaense. Vale ressaltar, ainda, que o setor serviços também tem uma participação relevante na MRH, dado que o principal pólo turístico do Estado, Foz do Iguaçu, encontra-se localizado nessa microrregião. Nesse sentido, a MRH foi responsável, em 1995, por $11,88 \%$ do PIB do setor secundário da economia paranaense.

Finalmente, as MRH de Londrina e Ponta Grossa são, respectivamente, a terceira e quarta regiões mais importantes na geração de bens e serviços no Paraná. Ambas produziram $15,13 \%$ do PIB paranaense, sendo que a primeira gerou 9,17\%, enquanto a segunda, 5,96\%. Nota-se, nestas microrregiões, uma distribuição eqüitativa da participação dos ramos de atividades econômicas no total da produção estadual.

Viu-se acima que essas MRHs respondem por cerca de dois terços do PIB estadual e, portanto, em torno delas, serão agregadas a demais MRHs, constituindo-se, desta forma, as quatro regiões-pólo que serão definidas e detalhadas no capítulo 4 deste trabalho.

\subsection{Distribuição espacial da indústria de transformação}

A indústria paranaense passou, no curso dos anos 70 e início da década de 80, por um acentuado processo de transformação, caracterizado pelo dinamismo e diversificação do parque industrial, notadamente pelas novas plantas instaladas na RMC.

Em termos de valor adicionado da indústria, a RMC vem, ao logo dos anos, concentrando participação, em detrimento das demais microrregiões do Estado. Em meados da década de 70, a RMC respondia por $32 \%$ do valor adicionado da indústria estadual, tendo essa participação aumentado para 58,3\% em 1994 (Tabela 2.5).

$\mathrm{Na}$ realidade, essa propensão concentradora da RMC deriva das economias externas, principalmente do entroncamento rodoferroviário-portuário (Lourenço, 1996b). Além disso, a maior disponibilidade de base em pesquisa científica e tecnológica e de 
infra-estrutura fisica propiciaram grandes inversões nos segmentos cimenteiro e refinaria de petróleo e o estabelecimento e consolidação da Cidade Industrial de Curitiba.

Tabela 2.5. Distribuição do valor adicionado da indústria de transformação por microrregião homogênea, Paraná: 1975 - 1994.

\begin{tabular}{lrrrrr}
\hline Microrregiões Homogêneas & 1975 & 1980 & 1985 & 1990 & 1994 \\
\hline Curitiba & 32,0 & 56,4 & 48,5 & 55,6 & 58,3 \\
Litoral Paranaense & 1,5 & 2,9 & 1,7 & 1,3 & 2,9 \\
Alto Ribeira & 0,5 & 0,3 & 0,2 & 0,1 & 0,1 \\
Alto Rio Negro Paranaense & 0,0 & 0,0 & 0,0 & 0,0 & 0,1 \\
Campos de Lapa & 1,5 & 0,8 & 1,2 & 1,6 & 1,3 \\
Campos de Ponta Grossa & 14,4 & 8,5 & 9,0 & 7,5 & 8,7 \\
Campos de Jaguariaíva & 0,5 & 0,2 & 1,0 & 1,0 & 1,2 \\
São Mateus do Sul & 0,2 & 0,1 & 0,0 & 0,0 & 0,3 \\
Colonial de Irati & 1,0 & 0,7 & 0,5 & 0,6 & 0,6 \\
Alto Ivaí & 0,1 & 0,0 & 0,0 & 0,0 & 0,1 \\
Norte Velho de Wenceslau Braz & 0,1 & 0,1 & 0,2 & 0,1 & 0,1 \\
Norte Velho de Jacarezinho & 3,1 & 2,7 & 2,9 & 2,3 & 2,0 \\
Algodoeira de Assaí & 1,0 & 0,9 & 0,8 & 0,5 & 0,2 \\
Norte Novo de Londrina & 14,5 & 9,1 & 11,6 & 9,1 & 7,8 \\
Norte Novo de Maringá & 5,3 & 3,2 & 4,6 & 5,0 & 2,8 \\
Norte Novíssimo de Paranavaí & 2,1 & 0,5 & 1,5 & 0,8 & 0,6 \\
Norte Novo de Apucarana & 2,7 & 1,4 & 2,3 & 1,9 & 1,7 \\
Norte Novíssimo de Umuarama & 2,2 & 1,0 & 2,0 & 1,2 & 1,6 \\
Campo Mourão & 2,0 & 1,8 & 1,7 & 1,7 & 1,7 \\
Pitanga & 0,3 & 0,1 & 0,0 & 0,1 & 0,1 \\
Extremo-Oeste Paranaense & 5,2 & 2,9 & 4,3 & 4,0 & 4,8 \\
Sudoeste Paranaense & 1,9 & 1,1 & 2,0 & 1,9 & 0,1 \\
Campos de Guarapuava & 3,8 & 2,7 & 2,1 & 2,0 & 1,6 \\
Médio Iguaçu & 4,1 & 2,6 & 1,9 & 1,7 & 1,3 \\
\hline TOTAL & 100,0 & 100,0 & 100,0 & 100,0 & 100,0 \\
\hline
\end{tabular}

Fonte: Lourenço, 1996b, p. 5.

As informações sobre a repartição geográfica da indústria paranaense apontam a constituição de dois pólos no interior do Estado, durante o primeiro qüinqüênio dos anos 70, eram representados pelas regiões de Londrina, que experimentava uma pronunciada modernização agroindustrial, e Ponta Grossa, com o estabelecimento do parque moageiro de soja e da indústria do trigo. 
Os referidos pólos geravam, juntos, naquela época, o equivalente à produção industrial da RMC. Em 1994, embora essas regiões tenham perdido participação relativa no valor adicionado da indústria estadual, elas ainda continuam sendo os principais eixos industriais do interior que, juntamente com a região Extremo-Oeste, contribuíram com $21,3 \%$ para a formação do valor adicionado industrial paranaense, correspondendo a pouco mais de um terço do gerado na RMC. 


\section{ANÁLISE DO INSUMO-PRODUTO}

Este capítulo tem como objetivo fazer um esboço teórico para a elaboração e implementação empírica de um modelo de insumo-produto inter-regional para a economia paranaense. Nesse sentido, faz uma apresentação simplificada da teoria básica do modelo de equilíbrio geral do tipo insumo-produto, bem como dos modelos interregionais. Em seguida, descreve a estrutura básica de um modelo inter-regional para duas regiões, o qual servirá de base para a construção do modelo inter-regional com quatro regiões objeto deste estudo.

\subsection{Antecedentes históricos}

Adam Smith e seus sucessores imediatos tratavam a economia sistematicamente como um todo. A preocupação de verificar a interdependência das atividades econômicas surgiu com o fisiocrata François Quesnay, em 1758, quando publicou o Tableau Économique. Esse trabalho foi a primeira sistematização do encadeamento dos fatos econômicos, que mostrou a circulação da renda entre as atividades, a partir da agricultura. Para Quesnay, a agricultura constituía a única atividade geradora de excedente que se distribuía entre as diferentes classes sociais, sendo a dos agricultores considerada a única produtiva. A indústria apenas transformava os produtos reunindo valores já existentes e o comércio era uma atividade estéril, pois nada produzia (Sandroni, 1989).

Depois de mais de um século do aparecimento do trabalho original de Quesnay, Walras foi o primeiro economista a afirmar, explicitamente, que o preço de uma mercadoria dependia do preço de todas as outras mercadorias (Davis, 1968). Em 
sua obra Éléments d'Économie Politique Pure (1874), Walras afastou-se do modelo de equilíbrio parcial de seus contemporâneos para direcionar sua atenção ao caso de um equilíbrio econômico geral, fazendo, dessa forma, a transição do equilíbrio parcial para o equilíbrio geral.

Walras desenvolveu um modelo que mostra a interdependência entre os setores de produção da economia e as demandas concorrentes de cada setor para os fatores de produção. Em seu modelo, Walras incluiu um conjunto de equações que representava a renda e os gastos do consumidores, permitindo a estes a substituição de produtos de um setor pelos obtidos em outros. Seu sistema, também levava em consideração os custos de produção em cada setor, a demanda e a oferta totais das mercadorias e a demanda e a oferta de fatores de produção (Miernyk, 1974).

Além de Walras, outros economistas, principalmente, Cassel e Pareto, contribuíram para o desenvolvimento da teoria do equilíbrio geral. Contudo, somente na década de 30 deste século é que foi atingido o ponto mais alto do trabalho iniciado por Quesnay, quando Leontief apresentou uma teoria geral de produção, baseada na noção de interdependência econômica. A aplicação empírica do modelo de equilíbrio geral data de 1936, quando Leontief publicou a primeira tabela de insumo-produto para a economia norte-americana. Nessa tabela, Leontief mostrou a maneira pela qual cada setor da economia dependia dos outros setores, ainda que de forma agregada.

Em 1941, uma nova versão, mais completa, do estudo de 1936, foi publicada com título de The Structure of the United States Economy, 1919-1939 e, a partir dai, a economia de insumo-produto difundiu-se rapidamente por todo o mundo. Segundo Miernyk (1974), a análise do insumo-produto ou análise das relações interindustriais tornou-se um importante ramo da economia, tanto que as tabelas de insumo-produto têm sido preparadas por mais de quarenta economias nacionais diferentes e o número de tabelas regionais ou de pequenas áreas tem crescido a um ritmo acelerado.

$\mathrm{O}$ método do insumo-produto transformou-se em instrumento de planejamento econômico largamente aceito e num importante guia para os tomadores de decisões em grande número de países. 


\subsection{Teoria básica do modelo de insumo-produto}

A teoria do insumo-produto decorreu dos estudos publicados por Wassily Leontief no final dos anos 30. Naquela oportunidade, Leontief analisou os grandes agregados macroeconômicos em termos de insumo-produto, implementando empiricamente o sistema de equilíbrio geral desenvolvido por Walras. Após estes estudos, Leontief $(1983$, p.5) salientou que:

"a análise de insumo-produto é uma extensão prática da teoria clássica de interdependência geral, que vê a economia inteira de uma região, de um pais ou inclusive do mundo como um só sistema e se propõe interpretar todas as suas funções em termos das propriedades especificas mensuráveis de sua estrutura".

Nesse sentido, a tabela de insumo-produto descreve o fluxo de bens e serviços entre todos os setores individuais de uma economia nacional durante um certo período de tempo, normalmente um ano, em valores monetários ${ }^{5}$. As linhas da tabela de insumo-produto registram os fluxos de saídas de produção, mostrando a distribuição da produção de um determinado setor produtivo entre os demais setores da economia. Por outro lado, as colunas da tabela registram as entradas de insumos necessárias à produção, exibindo a estrutura de insumos utilizada por cada setor da atividade produtiva.

Dentro desse contexto e seguindo Richardson (1972) e Miller e Blair (1985), as linhas da tabela de insumo-produto mostram as vendas da indústria ${ }^{6} i$ para as outras indústrias (demanda intermediária) e para o consumo das famílias, investimentos privados, gastos do governo e exportações (demanda final). A demanda intermediária mais a final compõem o produto bruto total ou as vendas da indústria i. Assim,

\footnotetext{
${ }^{5}$ Miller e Blair (1985) salientam que a compra e venda de mercadorias entre os setores são realizadas em unidades físicas. No entanto, devido a enormes problemas de mensuração quando um setor vende mais de uma mercadoria, a contabilidade geralmente é feita em termos monetários.

${ }^{6}$ Os termos setores e indústria são, geralmente, usados como sinônimos na análise de insumo-produto. Ver Miller e Blair (1985).
} 
considerando uma economia composta por $\boldsymbol{n}$ setores, o produto total bruto do setor $\boldsymbol{i}$ pode ser escrito da seguinte forma:

$$
X_{i}=\sum_{j}^{n} X_{i j}+\left(C_{i}+I_{i}+G_{i}+E_{i}\right)
$$

em que:

$X_{i}$ é a produção total do setor $i$ (demanda final e intermediária);

$X_{i j}$ é a produção do setor $i$ utilizada como insumo intermediário pelo setor $j$;

$C_{i}$ é a produção do setor $i$ que é comprada pelas famílias;

$I_{i}$ é a produção do setor $i$ que é destinada ao investimento;

$G_{i}$ é a produção do setor $i$ que é comprada pelo governo;

$E_{i}$ é a produção do setor $i$ que é destinada à exportação.

O somatório dos componentes $C_{i}, I_{i}$ e $G_{i}$ constitui a demanda final doméstica que, somada com $E_{i}$, forma a demanda final do setor $i, Y_{i}$.

Por outro lado, as colunas mostram as compras de insumos intermediários produzidos pela indústria $j$ e por todas as outras indústrias. As partes componentes do setor de pagamentos representam o pagamento pelos $j$ setores ao trabalho e por todos os outros itens do valor adicionado, como serviços do governo, capital (pagamentos de taxas), pagamentos de rendas, lucros, etc. Em adição, as importações de insumos são gravadas no setor de pagamentos e denotada por $M_{j}$. Assim, somando a coluna $j$ tem-se:

$$
X_{j}=\sum_{i}^{n} X_{i j}+L_{j}+V_{j}+M_{j} \quad i=1,2, \ldots, n
$$

em que:

$X_{j}$ é a produção total do setor $j$;

$L_{j}$ é valor do trabalho pago pelo setor $i$ na produção do setor $j$;

$V_{j}$ são outros valores adicionados pagos pelo setor $i$ na produção do setor $j$;

$M_{j}$ são as importações do setor $i$ para a produção do setor $j$.

Somando os totais de cada linha $\left(X_{i}\right)$ e os de cada coluna $\left(X_{j}\right)$, obtém-se o produto bruto total da economia $(X)$. Assim, tem-se:

$$
X=\sum_{j}^{n} X_{j}+C+I+G+E
$$




$$
X=\sum_{i}^{n} X_{i}+L+V+M
$$

Como os termos $\sum_{j}^{n} X_{j}$ e $\sum_{i}^{n} X_{i}$ são iguais, ambos se cancelam. Assim, obtém-se:

$$
L+V+M=C+I+G+E \text { e, transferindo as importações para o lado }
$$
direito da equação, tem-se:

$$
L+V=C+I+G+(E-M) \text {. }
$$

O lado esquerdo da equação (3.5) representa a Renda Nacional Bruta (pagamento total de fatores na economia) e o lado direito representa o Produto Nacional Bruto (total gasto com consumo e investimento em mercadorias, gasto total do governo e o saldo líquido da exportações e importações na economia).

Admitindo que a parcela de insumo $i$ requerida pelo setor $j$ seja diretamente proporcional à produção do setor $j$, tem-se que:

$$
X_{i j}=a_{i j} X_{j} \text { ou } a_{i j}=\frac{X_{i j}}{X_{j}}
$$

em que:

$a_{i j}$ é o coeficiente técnico ${ }^{7}$.

O coeficiente técnico indica a quantidade de insumo do setor $i$ necessária para se obter uma unidade do produto do setor $j$, sendo que $a_{i j}<1$ e $\left(1-a_{i j}\right)>0$.

$\mathrm{O}$ conjunto dos coeficientes $a_{i j}$ constitui a matriz $A$, de dimensão $n \times n$, cujos elementos $a_{i j}$ descrevem, em cada coluna da matriz $A$, a estrutura tecnológica do setor correspondente. Os valores dos coeficientes $a_{i j}$ são fixos e definem, portanto, funções de produção lineares e homogêneas. Assim, o sistema de insumo-produto de Leontief opera em condições de retornos constantes à escala.

Considerando que a matriz tecnológica fornece os fluxos intermediários em proporções fixas, pode-se derivar o sistema aberto de Leontief da seguinte forma:

$$
\sum_{j=1}^{n} a_{i j} X_{j}+Y_{i}=X_{i}
$$

\footnotetext{
${ }^{7}$ Também chamado de coeficiente de insumo-produto e coeficiente direto de insumo. Ver Miller e Blair (1985).
} 
Esta equação, escrita em forma matricial, torna-se:

$$
\boldsymbol{A} \boldsymbol{X}+\boldsymbol{Y}=\boldsymbol{X}
$$

em que $X$ e $Y$ são vetores coluna de ordem $(n \times 1)$.

Assumindo que as variações na demanda final, $Y$, são determinadas exógenamente, é possível obter a produção total, $\boldsymbol{X}$, que é necessária para satisfazer a demanda final. Assim, a produção total pode ser obtida da seguinte forma:

$$
X=(I-A)^{-1} Y
$$

em que $(I-A)^{-1}$ é a matriz de coeficientes técnicos de insumos diretos e indiretos, conhecida como matriz inversa de Leontief.

Considerando $B=(I-A)^{-1}$, cada elemento $b_{i j}$ da matriz inversa de Leontief quantifica os requisitos diretos e indiretos da produção total do setor $i$, que são necessários para produzir uma unidade da demanda final do setor $j$. De acordo com Haddad (1989), os elementos $b_{i j}$ da matriz inversa de Leontief, apresentam as seguintes características:

a) $b_{i j} \geq a_{i j}$, ou seja, cada elemento da matriz inversa de Leontief é maior ou igual ao respectivo elemento da matriz tecnológica, uma vez que o elemento $b_{i j}$ indica os efeitos diretos e indiretos sobre a produção do setor $i$ para atender a uma unidade monetária de demanda final do setor $j$, enquanto o elemento $a_{i j}$ indica apenas os efeitos diretos; a igualdade entre os dois coeficientes ocorre no caso particular em que os efeitos indiretos são nulos;

b) $b_{i j} \geq 0$, vale dizer, como os coeficientes técnicos de produção são fixos, não há possibilidade de substituição de insumos, de tal forma que uma expansão na demanda final do setor $j$ irá provocar um efeito positivo ou nulo sobre a produção do setor $i$, nunca um efeito negativo. $O$ efeito nulo surgirá se não houver interdependência direta entre os setores $i$ e $j$ e

c) $b_{i j} \geq 1$, se $i=j$, isto é, os elementos da diagonal principal da matriz inversa de Leontief serão sempre iguais a 1 ou maiores do que 1 , uma vez que o acréscimo de uma unidade monetária na demanda final de um setor deverá provocar uma expansão na produção desse setor de pelo menos uma unidade monetária. 
Apesar da análise do insumo-produto estar fundamentada em vários pressupostos $^{8}$, ela é, acima de tudo, um instrumento que pode ser empregado na análise de uma gama de variedade de problemas econômicos (Miernyk, 1974).

\subsection{Modelos de insumo-produto regional}

As primeiras aplicações do modelo de insumo-produto foram desenvolvidas em nível nacional. No entanto, mais recentemente, o maior interesse pela análise econômica em nível regional, tem induzido modificações nos modelos de insumoproduto visando a incorporar as características dos problemas regionais. Nesse sentido, Miller e Blair (1985) destacam duas particularidades de uma economia regional que devem permear os estudos regionais de insumo-produto:

a) a estrutura de produção de uma região particular pode ser idêntica ou bastante diferente daquela registrada na matriz de insumo-produto nacional, embora os dados de uma tabela de coeficientes de insumo-produto nacional sejam, logicamente, algum tipo de média dos dados relativos aos produtores individuais que estão localizados em regiões específicas;

b) geralmente, quanto menor a região, mais dependente é a sua economia com relação às áreas externas, tanto para as exportações dos produtos regionais quanto para as importações de insumos necessários ao seu processo produtivo.

Como conseqüência, os estudos regionais requerem, para a construção de suas matrizes, um maior número de informações, especialmente as relacionadas às exportações e importações entre as regiões. Além disso, as tecnologias de produção podem ser muito diferentes entre as várias regiões e a combinação dos insumos utilizados para um mesmo produto ou indústria pode variar de região para região.

Uma classificação interessante dos modelos regionais quanto à abrangência é feita por Miller e Blair (1985). Segundo os autores, existem os modelos para uma única região (single-region models) e os modelos para várias regiões (many-region models).

\footnotetext{
${ }^{8}$ Dentre eles podem ser citados: a) retomos constantes à escala; b) equilibrio geral da economia a um dado nível de preço e preços constantes.
} 
Os primeiros dividem um país ou região em duas partes, uma relativa à região alvo do estudo e a outra correspondente ao resto da economia. Nesses casos, o objetivo dos estudos é quantificar os impactos que uma variação na demanda final por bens produzidos na região de interesse teria sobre os setores nela localizados. Embora importantes, esses modelos não permitem captar nenhum tipo de ligação entre as diversas regiões do país.

Os modelos para várias regiões, seriam utilizados para blocos de países, várias regiões de um país ou estado e permitem estudar os fluxos inter-regionais e intraregionais de produção.

\subsection{Modelos de insumo-produto inter-regionais}

As análises inter-regionais são desenvolvidas por meio de coeficientes de insumos regionais, os quais permitem captar as interligações entre os setores demandantes e supridores de insumos da região de interesse. Os coeficientes de insumo e de comércio podem ser chamados, respectivamente, de coeficientes de insumo intraregional (pois medem o fluxo de insumos entre os setores de uma dada região) e coeficientes de insumo inter-regional (uma vez que quantificam o fluxo de insumos entre os setores de uma dada região e os setores do resto da economia).

De acordo com Fernandes (1997), os modelos de insumo-produto interregionais são úteis a múltiplos objetivos, dentre os quais destacam-se:

a) avaliação das diferenças regionais nas estruturas técnicas de produção;

b) avaliação dos efeitos inter-regionais resultantes de redistribuições geográficas nas atividades econômicas;

c) estudo de balanços de pagamentos regionais e dos fluxos de comércio inter-regional;

d) análise de impacto de variações nos programas de investimentos e/ou gastos públicos sobre diferentes regiões e

e) elaboração de planos regionais de desenvolvimento econômico e sistema de contas regionais. 
Por outro, como salientam Miller e Blair (1985), o modelo de insumoproduto inter-regional requer um montante grande de dados. A principal dificuldade na implementação de modelos de insumo-produto com muitas regiões está na indisponibilidade de dados sobre o fluxo de mercadorias entre setores e entre regiões, já que os gastos com coleta de dados estatísticos são bastante elevados. Isso tem gerado uma grande quantidade de modelos matemáticos para estimar os fluxos de mercadorias inter-regionais.

As matrizes de coeficientes de insumo-produto, base de todas as análises de insumo-produto, muitas vezes, não são construídas através dos ideais métodos censitários que propiciam informações específiças em nível regional. Diante dessa realidade, uma série de alternativas têm sido apresentadas como forma de contornar o problema, constituindo-se o que se convencionou chamar de métodos não censitários.

Os métodos não censitários, propostos, principalmente, a partir de meados dos anos 40, quando as análises em nível regional ganharam importância, são abordagens que se propõem a criar matrizes de coeficientes de insumo-produto, para uma região, a partir de informações relativas a outra região.

De acordo com Round (1983), os termos survey e nonsurvey sugerem a existência de dois grupos distintos e mutuamente excludentes de métodos. Entretanto, prossegue o autor, todas as matrizes de insumo-produto são matrizes híbridas, construídas a partir de técnicas parcialmente censitárias, existindo poucas ou nenhuma matriz inter-regional que não tenha sido criada com base em algum tipo de indicador ou técnicas que permitam uma maior sensibilidade dos dados.

\subsubsection{Modelos de insumo-produto inter-regionais censitários}

\subsubsection{Modelo de Isard}

O modelo desenvolvido por Isard (1951) é considerado, na literatura de insumo-produto, como o ideal. Esse modelo requer a construção de uma matriz de coeficientes técnicos para cada região, além da formulação de uma matriz de comércio 
inter-regional em que o produto é apresentado desagregado por setor e por região de origem e destino.

Isard parte do pressuposto de que os fluxos geográficos de produtos podem ser atribuídos a dois conjuntos básicos de fatores. $\mathrm{O}$ primeiro está relacionado, diretamente, com as desigualdades existentes na distribuição espacial da população, renda e recursos, enquanto o segundo envolve as indivisibilidades de produção e conseqüentes economias de escalas. Diante disso, argumenta que a elaboração de um modelo inter-regional deve levar em consideração essas desigualdades geográficas, assim como a heterogeneidade das áreas de mercado existentes. $\mathrm{O}$ autor considera que uma determinada mercadoria produzida numa região será considerada como diferente da mesma mercadoria produzida em outra região.

Assim, Isard estabelece que haverá uma função de produção do tipo Leontief específica para cada setor de cada região e os coeficientes técnicos dependerão da organização atual dos fluxos regionais de abastecimentos em cada setor, além da tecnologia utilizada e da estrutura de preços relativos.

Analogamente ao modelo de insumo-produto de Leontief, o modelo de Isard estabelece uma matriz inversa em que, tanto a estrutura tecnológica quanto a de abastecimento inter-regional, em nível de cada setor, permanecerão constantes. Dessa forma, se fossem dados os vetores de demanda final de cada região e estimados os valores dos elementos da matriz de coeficiente técnico, $A$, o modelo poderia ser utilizado para determinar os efeitos de encadeamentos entre setores e regiões, incrementos das exportações para outros países, do consumo autônomo e demais agregados econômicos, quando da ocorrência de variações exógenas na demanda final de uma determinada região.

A implementação empírica desse modelo é dificultada pelo seu grau de detalhamento e a necessidade de um imenso e diversificado volume de informações estatísticas, normalmente não coletadas pelos órgãos oficiais. Contudo, a evolução da teoria do insumo-produto tem gerado modelos inter-regionais alternativos, considerando as limitações dos dados, que tendem a aproximar-se do modelo ideal de Isard (Montoya, 1998). 


\subsubsection{Modelo de Metzler}

O artigo clássico de Metzler (1950) sobre a teoria da determinação da renda num sistema de regiões sem comércio internacional deu origem aos modelos interregionais que utilizam o instrumental de insumo-produto. Em seu artigo, Metzler analisa os impactos dos efeitos de transbordamento inter-regional, em função de uma variação autônoma da demanda final em uma dada região, e as conseqüentes propagações nos fluxos comerciais entre as regiões.

O modelo de Metzler considera que todos os preços, custos e taxas de câmbio permanecem constantes no período de análise e que as importações de uma região ou país são limitadas apenas pelo seu nível de renda. Por se tratar de um modelo de curto prazo, não leva em consideração os efeitos dos investimentos líquidos sobre a capacidade produtiva da região ou as repercussões de uma variação nessa capacidade sobre a demanda para novos investimentos (Haddad, 1976). Além disso, o modelo não discrimina os efeitos inter-regionais por setor produtivo de cada região onde ocorrem as despesas, não permitindo, dessa forma, visualizar os efeitos econômicos em cada setor de cada região, já que impossibilita saber quem compra ou quem vende insumos e produtos. Trata-se, portanto, de um modelo inter-regional do tipo agregado.

Esse modelo foi utilizado, no Brasil, por Haddad e Andrade (1974) para analisar a política fiscal e os desequilíbrios regionais que decorreriam da mudança do Imposto de Vendas e Consignações para o Imposto de Circulação de Mercadorias. Os resultados indicaram que o efeito "transbordamento" parece operar no sentido inverso, o que conduz à necessidade de repensar a tese "gastando-se em áreas desenvolvidas do país, acaba-se, em última instância, levando grandes benefícios para as áreas menos desenvolvidas".

\subsubsection{Modelos de insumo-produto inter-regionais parcialmente censitários}

\subsubsection{Modelo de Leontief-Hoffernberg}


O modelo intranacional de Leontief-Hoffernberg (1983) procura combinar a estrutura conceitual da análise de insumo-produto com a observação empírica de que algumas mercadorias são produzidas próximo dos lugares onde são consumidas, enquanto outras são transportadas a longas distâncias entre o local de origem e o de sua utilização. Portanto, as mercadorias são classificadas de acordo com o tamanho de seus mercados. Para certas mercadorias, o equilíbrio entre a produção e o consumo é atingido no nível local ou regional, enquanto, para outras, o equilíbrio ocorre em nível nacional ou internacional.

O modelo de Leontief-Hoffernberg deriva de uma matriz de insumo-produto nacional e objetiva calcular, por meio de etapas sucessivas, a quantidade de cada uma das mercadorias regionais e nacionais que deverá ser produzida em cada região, sendo dados os valores da demanda final. Esse modelo simplifica a necessidade de informações e, por isso, facilita a derivação da matriz de coeficientes de distribuição que indica as diversas percentagens da produção de cada uma das mercadorias nacionais que serão atribuídas para cada região. Na determinação desses coeficientes supõe-se que os padrões locacionais de produção de todas as mercadorias pertencentes à categoria nacional são conhecidos e mantidos constantes. Assim, a distribuição percentual da produção de uma mercadoria nacional entre as regiões do país é dada e permanece constante, mesmo quando ocorre uma expansão ou uma retração no volume total de produção da mesma mercadoria. Isto é, pressupõem-se expansões e retrações de produção proporcionais para todas as regiões.

O padrão de comércio produzido pelo modelo não permite identificar as origens das importações ou os destinos das exportações entre as diversas regiões. Em outras palavras, as regiões não são conectadas diretamente entre si, mas indiretamente pela economia como um todo. Nesse sentido, $\operatorname{Haddad}(1976$, p 225) destaca que:

"o modelo não apresenta equações de comportamento que permitam identificar os caminhos preferenciais que as mercadorias percorreriam no seu movimento entre as diversas regiões. É como se as mercadorias fossem colocadas pelos produtores num fundo 
nacional comum para serem retiradas pelos vários consumidores sem referência especifica às regiões de origem".

$\mathrm{O}$ autor argumenta que esta é a razão básica pela qual o modelo de LeontiefHoffernberg é denominado intranacional e não inter-regional.

Segundo Haddad (1976), esse modelo aplica-se adequadamente a estudos que têm como objetivo examinar os efeitos regionais de políticas nacionais alternativas de comércio internacional ou de investimento, principalmente quando não se sabe antecipadamente o padrão de localização da nova capacidade produtiva a ser instalada.

A aplicação empírica de uma versão adaptada desse modelo foi utilizada por Leontief et al. (1983) com o objetivo de determinar o efeito que uma redução hipotética da demanda militar, acompanhada de um aumento compensador da demanda não militar, teria sobre a composição industrial e a distribuição regional do emprego nos Estados Unidos.

\subsubsection{Modelo de Leontief-Strout}

Esse modelo foi desenvolvido por Leontief e Strout (1963) e utilizado para estudar a economia americana no período de 1950 a 1958. Os autores introduziram equações de comportamento das exportações de mercadorias por origem e destino, tendo como característica principal a utilização do modelo gravitacional para predizer fluxos inter-regionais de produtos.

A pressuposição básica do modelo é de que as exportações de uma mercadoria de uma região para outra são diretamente proporcionais à sua produção total na região de origem e ao seu consumo total na região de destino e, inversamente proporcionais à distância entre as duas regiões, não especificando, portanto, os diversos setores exportadores e importadores daquela mercadoria.

Segundo Cavalcante (1994), esse modelo é adequado para analisar mudanças nos padrões de comércio inter-regional, ocorridas devido a alterações na produção, consumo e custo de transferência entre as regiões de origem e de destino. 
As vantagens desse modelo são a exigência de poucas informações estatísticas e a simples operacionalização computacional para a sua implementação. No entanto, o problema crítico de sua aplicação advêm da mensuração do coeficiente do comércio que requer o levantamento dos custos de transferência dos produtos de uma região para outra.

\subsubsection{Modelo de Hansen e Tiebout}

O modelo, denominado de coeficiente de linha, foi formulado pela primeira vez por Hansen e Tibout (1963) para estudar três regiões do estado da Califórnia, Estados Unidos, usando dados do ano de 1960. Posteriormente, Polenske (1970) também empregou essa técnica para estudar a economia japonesa.

Em essência, esse modelo enfoca a distribuição da produção regional que se destina ao mercado doméstico ou à exportação para outras regiões. A sua característica principal é que a proporção do produto vendido pelos diversas regiões é a mesma, independentemente do nível de demanda das regiões compradoras. Ademais, a utilização deste enfoque implica que os coeficientes de venda não sejam afetados pelas importações.

\subsubsection{Modelo de Chenery e Moses}

O modelo desenvolvido por Chenery (1953) tinha como objetivo básico analisar os impactos que os investimentos em larga escala, realizados na região Sul da Itália, poderiam ter sobre a produção e a renda dentro da própria região e no restante do país. Por outro lado, Moses (1955) construiu um modelo semelhante ao de Chenery com o objetivo de analisar empiricamente a estabilidade dos coeficientes de abastecimento inter-regional. Moses aplicou sua técnica em três grandes regiões dos Estados Unidos, utilizando cinco grupos de mercadorias, durante os anos de 1947 a 1949.

A hipótese central do modelo de Chenery-Moses é de que cada região importa uma proporção fixa de suas necessidades de uma determinada mercadoria de 
uma região específica e que cada setor segue o mesmo padrão de importação da região como um todo.

A operacionalização desse modelo exige que sejam conhecidas as matrizes de coeficientes técnicos de cada região e a de coeficiente de comércio inter-regional, por região de origem e destino e por produto de origem. No entanto, a estrutura de abastecimento intra e inter-regional é desconhecida, pois para cada mercadoria produzida, desconhece-se quanto de seus insumos são produzidos na região e quanto deles são produzidos em outras regiões.

Com conhecimento das exportações e importações agregadas em nível regional e, com a utilização do uso de uma matriz de coeficientes de abastecimentos intra e inter-regional, Chenery argumenta ser possível estimar a estrutura de abastecimento inter-regional em nível interindustrial. Essa matriz é construída levando em consideração proporções fixas coluna: por exemplo, se um quinto do total de aço consumido pela região A for proveniente da região $\mathrm{B}$ então, a todo aço consumido em cada um dos setores produtivos de A será aplicado um coeficiente igual a 0,2 para destacar a parcela que se supõe importada de B. Desse modo, os coeficientes de abastecimento são iguais à participação de cada região nos fluxos intra e inter-regionais. Esse pressuposto reduz significativamente o volume de informações necessárias para que seja implementado o modelo.

No Brasil, Haddad e Andrade (1974) aplicaram o modelo de Chenery para examinar a tese de que a substituição do antigo Imposto de Vendas e Consignações (IVC) para o Imposto de Circulação de Mercadorias (ICM) estaria prejudicando os estados menos desenvolvidos do país. Os resultados indicaram que a substituição do IVC pelo ICM não prejudicou os estados menos desenvolvidos, evidenciando que a hipótese de Chenery é consistente, apesar da limitação dos dados disponíveis utilizados pelos autores.

Cavalcante (1994) também utilizou esse modelo para analisar as mudanças estruturais que ocorreram na economia do Nordeste brasileiro durante o período de 1975 a 1980. Os resultados obtidos indicaram que não houve mudanças significativas na estrutura produtiva da economia nordestina. 
Outro estudo mais recente foi realizado por Fernandes (1997). Este autor empregou o modelo de Chenery-Moses para estudar as relações de interdependência entre as estruturas produtivas de Minas Gerais e do Resto do Brasil para o ano de 1980. A principal conclusão do estudo indicou que os impactos setoriais dos investimentos industriais realizados em Minas Gerais foram internalizados predominantemente dentro da própria região.

\subsection{Estrutura básica de modelo inter-regional para duas regiões}

O modelo inter-regional, descrito a seguir, leva em consideração o referencial teórico básico do modelo de Isard que será empregado nesse estudo. Ele ilustra o caso para uma economia com duas regiões $(L$ e $C$ ) e $n$ setores, podendo, no entanto, ser estendido para qualquer número de regiões. $O$ quadro simplificado do modelo de insumo-produto inter-regional está representado no Quadro 3.1.

$O$ produto do setor $i$ na região $L$ pode ser expresso por:

$$
X_{i}^{L}=Z_{i 1}^{L L}+Z_{i 2}^{L L}+\ldots+Z_{i n}^{L L}+Z_{i 1}^{L C}+Z_{i 2}^{L C}+\ldots+Z_{i n}^{L C}+Y_{i}^{L}
$$

Os elementos com o sobrescritos $L L$ representam as vendas do setor $i$ na região $L$ para os $\boldsymbol{n}$ setores desta região e os termos com sobrescritos $L C$ representam o fluxo de comércio inter-regional do setor $i$ na região $L$ para os $n$ setores da região $C$. O termo $Y_{i}^{L}$ representa as vendas para a demanda final do produto do setor $i$ na região $L$, o que inclui todos os componentes da demanda final a saber, consumo das famílias, consumo do governo, investimentos e exportações, exceto a parte das exportações destinadas aos setores produtivos da região $C$. Uma equação similar a (3.10) pode ser escrita para $X_{i}^{C}$.

$\mathrm{O}$ coeficiente de insumo regional para a região $L$ é dado por:

$$
a_{i j}^{L L}=\frac{Z_{i j}^{L L}}{X_{j}^{L}}
$$

e para a região $C$ 


$$
a_{i j}^{c C}=\frac{Z_{i j}^{C C}}{X_{j}^{C}}
$$

em que:

$Z_{i j}^{L L}$ representa o fluxo, em unidades monetárias, dos produtos do setor $i$ da região $L$ para o setor $j$ da região $L$;

$X_{j}^{L}$ representa o valor da produção total do setor $j$ da região $L$;

$Z_{i j}^{C C}$ representa o fluxo, em unidades monetárias, dos produtos do setor $i$ da região $C$ para o setor $j$ da região $C$;

$X_{j}^{C}$ representa o valor da produção total do setor $j$ da região $C$.

Ambos os coeficientes mostram a quantidade de insumo do setor $i$ da região em estudo necessária para a produção no setor $j$ da mesma região.

Quadro 3.1. Quadro simplificado de um modelo de insumo-produto inter-regional.

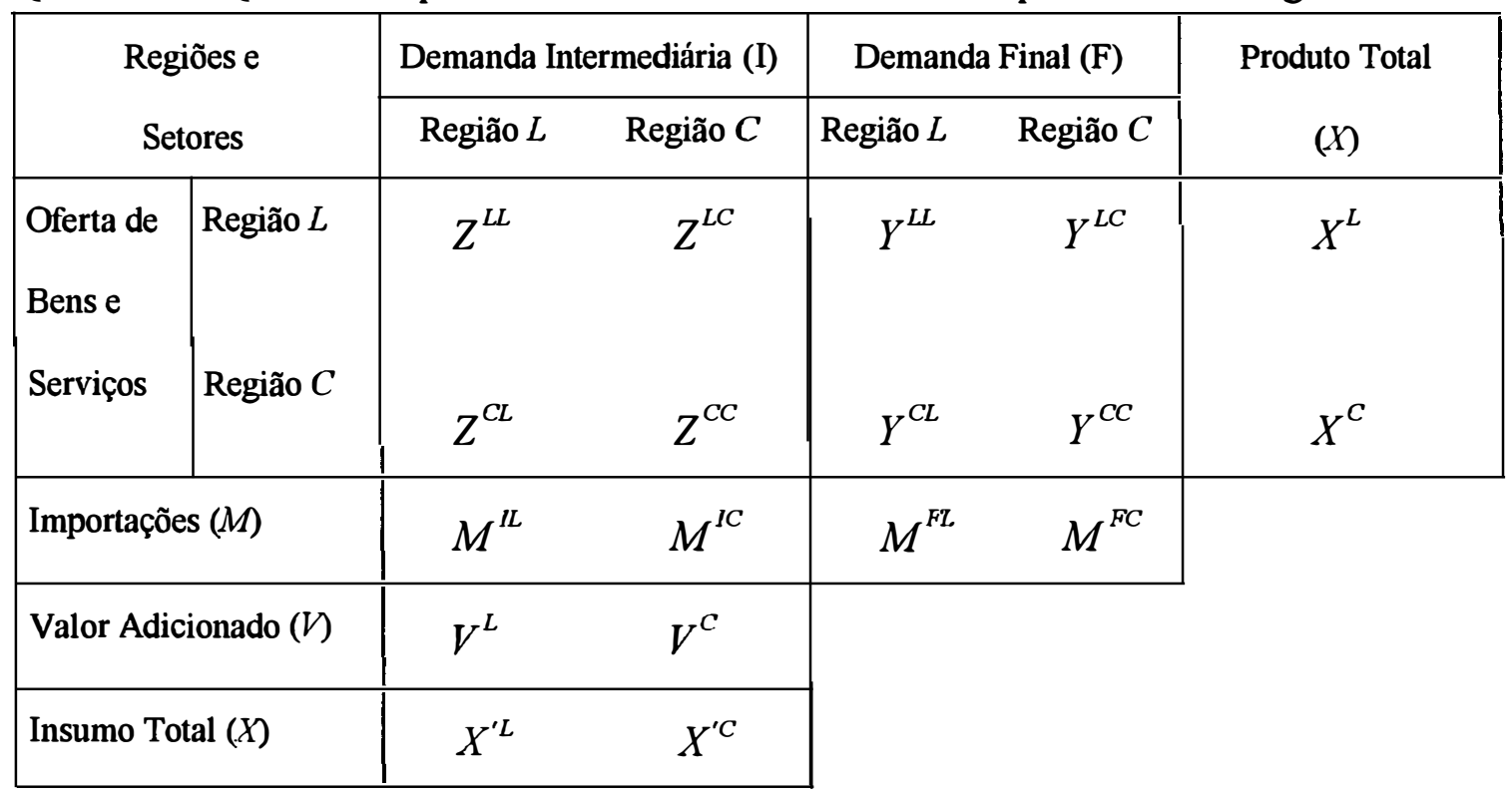

O coeficiente inter-regional de comercialização da região $L$ para a região $C$ é dado por: 


$$
a_{i j}^{L C}=\frac{Z_{i j}^{L C}}{X_{j}^{C}}
$$

enquanto o da região $C$ para a região $L$ é expresso por:

$$
a_{i j}^{C L}=\frac{Z_{i j}^{C L}}{X_{j}^{C}}
$$

em que:

$Z_{i j}^{L C}$ representa o fluxo, em unidades monetárias, dos produtos do setor $i$ da região $L$ para o setor $j$ da região $C$;

$X_{j}^{C}$ representa o valor da produção total do setor $j$ da região $C$;

$Z_{i j}^{C L}$ representa o fluxo, em unidades monetárias, dos produtos do setor $i$ da região $C$ para o setor $j$ da região $L$;

$X_{j}^{L}$ representa o valor da produção total do setor $j$ da região $L$.

Os coeficientes inter-regionais mostram o valor do insumo $i$ produzido na região $L(C)$ que é usado na produção do setor $j$ na região $C(L)$.

Substituindo (3.12) e (3.14) em (3.11), tem-se:

$$
X_{i}^{L}=a_{i 1}^{L L} X_{1}^{L}+a_{i 2}^{L L} X_{2}^{L}+\ldots+a_{i n}^{L L} X_{n}^{L}+a_{i 1}^{L C} X_{1}^{C}+a_{i 2}^{L C} X_{2}^{C}+\ldots+a_{i n}^{L C} X_{n}^{L C}+Y_{i}^{L}
$$

Uma expressão similar pode ser definida para $X_{i}^{C}$.

Movendo todos os termos envolvendo $X^{L}$ e $X^{c}$ para a esquerda da equação (3.15), tem-se:

$$
\left(1-a_{i 1}^{L L}\right) X_{1}^{L}-a_{i 2}^{L L} X_{2}^{L}-\ldots-a_{i n}^{L L} X_{n}^{L}-a_{i 1}^{L C} X_{1}^{C}-a_{i 2}^{L C} X_{2}^{C}-\ldots-a_{i n}^{L C} X_{n}^{C}=Y_{i}^{L}
$$

Novamente, uma equação similar pode ser expressa para $Y_{i}^{C}$.

Para o presente caso, em que as regiões $L$ e $C$ têm $n$ setores, podem-se definir as seguintes matrizes $(n \times n): A^{L L}=Z^{L L}\left(\hat{\mathrm{X}}^{L}\right)^{-1}, A^{C C}=Z^{C C}\left(\hat{\mathrm{X}}^{C}\right)^{-1}, A^{L C}=Z^{L C}$ $\left(\hat{\mathrm{X}}^{C}\right)^{-1} \mathbf{e} A^{C L}=Z^{C L}\left(\hat{\mathrm{X}}^{L}\right)^{-1}$, que serão usadas para representar as expressões relativas a $Y_{i}^{L}$ e $Y_{i}^{C}$ de forma matricial: 


$$
\begin{aligned}
& \left(I-A^{L L}\right) X^{L}-A^{L C} X^{C}=Y^{L} \\
& -A^{C L} X^{L}+\left(I-A^{c C}\right) X^{C}=Y^{C}
\end{aligned}
$$

em que:

$Y^{L}$ e $Y^{C}$ são, respectivamente, os vetores de demanda final para as mercadorias das regiões $L$ e $C$.

Assim, a matriz completa de coeficientes para o modelo inter-regional com duas regiões pode ser formada por quatro submatrizes:

$$
A=\left[\begin{array}{c:c}
A^{L L} & A^{L C} \\
\hdashline A^{C L} & A^{C C}
\end{array}\right]
$$

Similarmente, definem-se os vetores de produto bruto $(n \times 1)$, contendo $X^{L}$ e $X^{C}$, para a região $L$ e $C$, respectivamente:

$$
X=\left[\begin{array}{c}
X^{L} \\
\hdashline X^{C}
\end{array}\right]
$$

e da demanda final $(n \times 1), Y^{L}$ e $Y^{C}$ :

$$
Y=\left[\begin{array}{l}
Y^{L} \\
Y^{C}
\end{array}\right]
$$

Por fim, o modelo de insumo-produto inter-regional completo para duas regiões é representado como:

$$
(I-A) X=Y
$$

sendo a solução dada por:

$$
\boldsymbol{X}=(\boldsymbol{I}-\boldsymbol{A})^{-1} \boldsymbol{Y}
$$

A utilização do modelo inter-regional pressupõe constantes os coeficientes de insumo regional e os coeficientes de comercialização, o que fixa a estrutura de produção em cada região e o padrão de comércio entre as mesmas. 


\section{METOdOLOGIA PARA A CONSTRUÇÃO DA MATRIZ DE INSUMO - PRODUTO PARA O PARANÁ}

O propósito deste capítulo é descrever os procedimentos para estimar a matriz de insumo-produto para o Paraná, o que será feito por meio da técnica do quociente locacional simples. Na seqüência, apresentam-se os critérios da divisão da economia paranaense em quatro pólos regionais, os quais constituirão a matriz interregional, objeto de análise.

\subsection{Matriz de insumo-produto para o Paraná - 1995}

Para a realização dessa tese foi necessário, inicialmente, estimar uma matriz de insumo-produto para o Estado do Paraná. Esta foi elaborada a partir da matriz de insumo-produto do Brasil de 1995 (IBGE, 1997). Existem técnicas não censitários para a estimativa de matrizes de insumo-produto, dentre as quais pode-se destacar o método do quociente locacional simples ${ }^{9}$. Este método foi escolhido por ser muito utilizado em estudos dessa natureza e as matrizes estimadas por meio desta técnica possibilitam obter coeficientes técnicos bastante próximos da realidade, permitindo a análise regional e a formulação de sugestões de políticas locais de industrialização (Souza, 1997).

\subsubsection{Método do quociente locacional}

O método do quociente locacional constitui uma técnica bastante empregada em Economia Regional, quando se deseja obter uma primeira aproximação do valor de

\footnotetext{
${ }^{9}$ É oportuno salientar a existência de outros métodos de regionalização de matrizes, merecendo destaque os do balanço de mercadorias e do balanço iterativo. Para mais detalhes ver Isard (1953 e 1989), Round (1983), Bacharach (1970), Miller e Blair (1985) e Haddad (1989).
} 
deterninadas variáveis para uma região qualquer, a partir do valor das mesmas variáveis obtidas por dados censitários em nível nacional. Segundo Souza (1997), a utilização dessa técnica supõe que a economia da região $j$ mantém a mesma estrutura da economia nacional em relação à indústria $i$.

Assim, o quociente locacional simples para o setor $i$ na região $R$, conforne Miller e Blair (1985), é definido como:

$$
L Q_{i}^{R}=\left[\frac{X_{i}^{R} / X^{R}}{X_{i}^{N} / X^{N}}\right]
$$

em que:

$X_{i}^{R}$ e $X^{R}$ denotam, respectivamente, os valores da produção do setor $i$ e da produção total na região $R$;

$X_{i}^{N}$ e $X^{N}$ denotam, respectivamente, os valores da produção do setor $i$ e da produção total nacional.

Quando os dados de produção de uma indústria, em uma dada região, não estão disponíveis, podem-se utilizar outras medidas ou variáveis por setor, dentre as quais destacam-se o emprego, a renda pessoal recebida, o valor adicionado, a demanda final, etc. (Miller e Blair, 1985 e Round, 1983).

O presente método consiste em comparar a proporção do produto total da região $R$ que é devida ao setor $i$ com a proporção do produto total nacional advindo do setor $i$ em nível nacional. O quociente locacional simples pode ser visto como uma medida da habilidade da indústria regional $i$ para atender à demanda de outras indústrias e à demanda final da região. Se o valor do quociente for menor do que um, a indústria $i$ é menos concentrada na região do que em nível nacional. Se for maior do que um, a indústria $i$ é mais concentrada na região do que e nível nacional. Assim, para a linha $i$ de uma tabela regional estimada, tem-se:

$$
a_{i j}^{R R}= \begin{cases}a_{i j}^{N}\left(L Q_{i}^{R}\right) & \text { se } L Q_{i}^{R}<1 \\ a_{i j}^{N} & \text { se } L Q_{i}^{R} \geq 1\end{cases}
$$

em que: 
$a_{i j}^{R R}$ é o coeficiente de insumo regional;

$a_{i j}^{N}$ é o coeficiente técnico nacional;

Esse método também foi empregado por Kureski (1999) para estimar a matriz de insumo-produto do Paraná para o ano de 1985.

\subsubsection{Procedimentos de construção da matriz de insumo-produto para o Paraná}

Para a construção da matriz regional do Paraná foi empregada a matriz nacional de insumo-produto para o ano de 1995 (IBGE, 1997). Mais especificamente, partiu-se das Tabelas de Produção e das Tabelas de Oferta e Demanda da Produção Nacional a Preço Básico ${ }^{10}$, essas últimas também chamadas de Tabela de Uso.

Considerando que esta pesquisa procurou ressaltar os setores mais importantes da estrutura produtiva da economia paranaense, optou-se por agregar a matriz do Brasil em 31 setores e manter os 80 produtos da matriz nacional original. Dessa forma, a tabela de produção para o Paraná e para as regiões-pólo apresenta 31 setores e 80 produtos e a de uso, 80 produtos e 31 setores. A agregação dos setores efetuada para este estudo encontra-se detalhada nos Quadros 4.1 e 4.2.

O Quadro 4.3 mostra a estrutura do sistema de relações de insumo-produto usada na construção das matrizes para o Paraná. A Tabela de Produção nacional, da qual se origina a tabela $V^{N}(s \times p)$, fornece informações sobre a origem setorial dos bens e serviços produzidos em determinado ano na economia. As linhas indicam em quais setores os produtos são produzidos, enquanto as colunas mostram a origem setorial dos produtos. Por outro lado, a Tabela de Uso nacional, de onde provém a tabela de uso $U^{N}$ ( $p x s$ ), mostra, nas linhas, os produtos oferecidos para cada setor (oferta) e nas colunas, os produtos demandados em cada setor (demanda) da economia. ${ }^{11}$

\footnotetext{
${ }^{10}$ Segundo Considera et al. (1997), preço básico é o valor dos bens e serviços quando se computam apenas os custos de produção (custos de bens e serviços intermediários e remunerações dos fatores de produção) adicionados dos outros impostos sobre a produção, líquidos de outros subsídios à produção. E como se fosse o preço dos bens e serviços na porta da fábrica.

${ }^{11}$ As letras $N$ e $R$ são usadas para especificar, respectivamente, matrizes ou vetores nacionais e regionais, enquanto pe $s$ representam produto e setor, respectivamente.
} 
Quadro 4.1. Agregação dos setores usados na construção do sistema inter-regional do Paraná.

\begin{tabular}{|c|c|c|c|}
\hline Ordem & SETORES DA MATRIZ - IBGE & Ordem & SETORES AGREGADOS \\
\hline 1 & Agropecuária & 1 & Agropecuária \\
\hline 2 & Extrativa Mineral & \multirow{2}{*}{2} & \multirow{2}{*}{ Extrativa Mineral } \\
\hline 3 & Extração de Petróleo e Gás & & \\
\hline 4 & Minerais não Metálicos & 3 & Fabricação de Minerais não Metálicos \\
\hline 5 & Siderurgia & \multirow{3}{*}{4} & \multirow{3}{*}{ Metalurgia } \\
\hline 6 & Metalurgia não Ferrosos & & \\
\hline 7 & Outros Metalúrgicos & & \\
\hline 8 & Máquinas Tratores & 5 & Máquinas e Equipamentos \\
\hline 9 & Material Elétrico & \multirow{2}{*}{6} & \multirow{2}{*}{ Material Elétrico/Eletrônico } \\
\hline 10 & Equipamentos Eletrônicos & & \\
\hline 11 & Automóveis, Caminhões e Ōnibus & \multirow{2}{*}{7} & \multirow{2}{*}{ Material de Transportes } \\
\hline 12 & Outros Veículos e Peças & & \\
\hline 13 & Madeira e Mobiliário & 8 & Madeira e Mobiliário \\
\hline 14 & Papel e Gráfica & 9 & Celulose, Papel e Gráfica \\
\hline 15 & Indústria da Borracha & 10 & Indústria da Borracha \\
\hline 16 & Elementos Químicos & \multirow{3}{*}{11} & \multirow{3}{*}{ Química } \\
\hline 17 & Refino do Petróleo & & \\
\hline 18 & Químicos Diversos & & \\
\hline 19 & Farmacêutica e Perfumaria & 12 & Indústria Farmacêutica e de Perfumaria \\
\hline 20 & Artigos de Plástico & 13 & Indústria de Artigos de Plástico \\
\hline 21 & Indústria Têxtil & 14 & Indústria Têxtil \\
\hline 22 & Artigos do Vestuário & \multirow{2}{*}{15} & \multirow{2}{*}{ Vestuário, Calçados, Couros e Peles } \\
\hline 23 & Fabricação de Calçados & & \\
\hline 24 & Indústria do Café & 16 & Indústria do Café \\
\hline 25 & Beneficiamento de Produtos Vegetais & 17 & Beneficiamento de Produtos Vegetais \\
\hline 26 & Abate de Animais & 18 & Abate de Animais \\
\hline 27 & Indústria de Laticínios & 19 & Indústria de Laticínios \\
\hline 28 & Indústria de Açúcar & 20 & Fabricação de Açúcar \\
\hline 29 & Fabricação de Óleos Vegetais & 21 & Fabricação de Oleos Vegetais \\
\hline 30 & Outros Produtos Alimentares & 22 & Fabricação de Outros Produtos Alimentares \\
\hline 31 & Indústrias Diversas & 23 & | Indústrias Diversas \\
\hline 32 & Serviços Industriais de Utilidade Pública & 24 & Servos Industriais de Utilidade Pública \\
\hline 33 & Construção Civil & 25 & Construção Civil \\
\hline 34 & Comércio & 26 & Comércio \\
\hline 35 & Transporte & 27 & Transporte \\
\hline 36 & Comunicações & 28 & Comunicações \\
\hline 37 & Instituições Financeiras & 29 & Instituições Financeiras \\
\hline 38 & Administração pública & 30 & Administração Pública \\
\hline 39 & Serviços Prestados às Famílias & \multirow{4}{*}{31} & \multirow{4}{*}{ Outros Serviços } \\
\hline 40 & Serviços Prestados às Empresas & & \\
\hline 41 & Aluguel de Imóveis & & \\
\hline 42 & | Serviços Privados não Mercantis & & \\
\hline
\end{tabular}


Quadro 4.2. Produtos componentes dos setores do sistema inter-regional do Paraná.

\begin{tabular}{|c|c|c|c|}
\hline Ordem & PRODUTOS DA MATRIZ - IBGE & Ordem & SETORES AGREGADOS \\
\hline 1 & Café em coco & \multirow{11}{*}{1} & \multirow{11}{*}{ Agropecuária } \\
\hline 2 & Cana-de-açúcar & & \\
\hline 3 & Arroz em casca & & \\
\hline 4 & Trigo em grão & & \\
\hline 5 & Algodão em caroço & & \\
\hline 6 & Soja em grão & & \\
\hline 7 & Milho em grão & & \\
\hline 8 & Bovinos e suínos & & \\
\hline 9 & Leite natural & & \\
\hline 10 & Aves vivas & & \\
\hline 11 & Outros produtos agropecuários & & \\
\hline 12 & Minério de ferro & \multirow{4}{*}{2} & \multirow{4}{*}{ Extrativa Mineral } \\
\hline 13 & Outros minerais & & \\
\hline 14 & Petróleo e gás & & \\
\hline 15 & Carvão e outros & & \\
\hline 16 & Produtos minerais não metálicos & 3 & Fabricação de Minerais não Metálicos \\
\hline 17 & Produtos siderúrgicos básicos & \multirow{4}{*}{4} & \multirow{4}{*}{ Metalurgia } \\
\hline 18 & Laminados de aço & & \\
\hline 19 & Produtos metalúrgicos não ferrosos & & \\
\hline 20 & Outros produtos metalúrgicos & & \\
\hline 21 & Fab. e manut. de máq. e equipamentos & \multirow{2}{*}{5} & \multirow{2}{*}{ Máquinas e Equipamentos } \\
\hline 22 & Tratores e máquinas terraplanagem & & \\
\hline 23 & Material elétrico & \multirow{2}{*}{6} & \multirow{2}{*}{ Material Elétrico/Eletrônico } \\
\hline 24 & Equipamentos eletrônicos & & \\
\hline 25 & Automóveis, caminhões e ônibus & \multirow{2}{*}{7} & \multirow{2}{*}{ Material de Transportes } \\
\hline 26 & Outros veículos e peças & & \\
\hline 27 & Madeira e mobiliário & 8 & Madeira e Mobiliário \\
\hline 28 & Papel, celulose, papelão e artefatos & 9 & Celulose, Papel e Gráfica \\
\hline 29 & Produtos derivados da borracha & 10 & Indústria da Borracha \\
\hline 30 & Elementos químicos não petroquímicos & \multirow{11}{*}{11} & \multirow{11}{*}{ Química } \\
\hline 31 & Álcool de cana e de cereais & & \\
\hline 32 & Gasolina pura & & \\
\hline 33 & Óleos combustíveis & & \\
\hline 34 & Outros produtos do refino & & \\
\hline 35 & Produtos petroquímicos básicos & & \\
\hline 36 & Resinas & & \\
\hline 37 & Gasoálcool & & \\
\hline 38 & Adubos & & \\
\hline 39 & Tintas & & \\
\hline 40 & Outros produtos químicos & & \\
\hline
\end{tabular}


Quadro 4.2 Produtos componentes dos setores do sistema inter-regional do Paraná.

(Continuação)

\begin{tabular}{|c|c|c|c|}
\hline 41 & Produtos farmacêuticos e de perfumaria & 12 & Indústria Fanmacêutica e de Perfumaria \\
\hline 42 & Artigos de plástico & 13 & Indústria de Artigos de Plástico \\
\hline 43 & Fios têxteis naturais & \multirow{5}{*}{14} & \multirow{5}{*}{ Indústria Têxtil } \\
\hline 44 & Tecidos naturais & & \\
\hline 45 & Fios têxteis artificiais & & \\
\hline 46 & Tecidos artificiais & & \\
\hline 47 & Outros produtos têxteis & & \\
\hline 48 & Artigos do vestuário & \multirow{2}{*}{15} & \multirow{2}{*}{ Vestuário, Calçados, Couros e Peles } \\
\hline 49 & Produtos de couro e calçados & & \\
\hline 50 & Produtos do café & 16 & Indústria do Café \\
\hline 51 & Arroz beneficiado & \multirow{3}{*}{17} & \multirow{3}{*}{ Beneficiamento de Produtos Vegetais } \\
\hline 52 & Farinha de trigo & & \\
\hline 53 & Outros produtos vegetais beneficiados & & \\
\hline 54 & Carne bovina & \multirow{2}{*}{18} & \multirow{2}{*}{ Abate de Animais } \\
\hline 55 & Carne de aves abatidas & & \\
\hline 56 & Leite beneficiado & \multirow{2}{*}{19} & \multirow{2}{*}{ Indústria de Laticínios } \\
\hline 57 & Outros laticínios & & \\
\hline 58 & Açúcar & 20 & Fabricação de Açúcar \\
\hline 59 & Óleos vegetais em bruto & \multirow{2}{*}{21} & \multirow{2}{*}{ Fabricação de Óleos Vegetais } \\
\hline 60 & Óleos vegetais refinados & & \\
\hline 61 & Outros prod. alimentares inclusive rações & \multirow{2}{*}{22} & \multirow{2}{*}{ Fabricação de Outros Produtos Alimentares } \\
\hline 62 & Bebidas & & \\
\hline 63 & Produtos diversos & 23 & Indústrias Diversas \\
\hline 64 & Serviços industriais de utilidade pública & 24 & Servos Industriais de Utilidade Pública \\
\hline 65 & Produtos da construção civil & 25 & Construção Civil \\
\hline 66 & Margem de comércio & 26 & Comércio \\
\hline 67 & Margem de transporte & 27 & Transporte \\
\hline 68 & Comunicações & 28 & Comunicações \\
\hline 69 & Seguros & \multirow{2}{*}{29} & \multirow{2}{*}{ Instituições Financeiras } \\
\hline 70 & Serviços financeiros & & \\
\hline 71 & Administração pública & \multirow{3}{*}{30} & \multirow{3}{*}{ Administração Pública } \\
\hline 72 & Saúde pública & & \\
\hline 73 & Educação pública & & \\
\hline 74 & Alojamento e alimentação & \multirow{7}{*}{31} & \multirow{7}{*}{ Outros Serviços } \\
\hline 75 & Outros serviços & & \\
\hline 76 & Saúde e educação mercantis & & \\
\hline 77 & Serviços prestados às empresas & & \\
\hline 78 & Aluguel de imóveis & & \\
\hline 79 & Aluguel imputado & & \\
\hline 80 & Serviços privados não mercantis & & \\
\hline
\end{tabular}


Quadro 4.3. Relações de insumo-produto usadas na construção das matrizes para o Paraná.

\begin{tabular}{|l|c|c|c|c|}
\hline & Produto & Setor & Demanda Final & Produto Total \\
\cline { 3 - 4 } & & $U^{N}\left(U^{R}\right)$ & $E$ & $Q^{N}\left(Q^{R}\right)$ \\
\hline Sroduto & $V^{N}\left(V^{R}\right)$ & $Z$ & $Y$ & $X^{N}\left(X^{R}\right)$ \\
\hline Importações & & $M$ & $M F$ & \multicolumn{2}{|l}{} \\
\cline { 1 - 3 } Valor Adicionado & & $W$ & \multicolumn{2}{|l}{} \\
\cline { 1 - 3 } Insumo Total & $Q^{\prime N}\left(Q^{\prime R}\right)$ & $X^{\prime N}\left(X^{\prime R}\right)$ & &
\end{tabular}

Assim, com base na tabela $U^{N} \mathrm{e}$ no vetor $X^{N}\left(\begin{array}{lll}s & x & l\end{array}\right)$, este último representando a produção nacional por setor, calculou-se a matriz $B^{N}\left(\begin{array}{lll}p & x & s\end{array}\right)$ da seguinte forma:

$$
B^{N}=U^{N}\left(\hat{X}^{N}\right)^{-1}
$$

em que $B^{N}$ é a matriz nacional dos coeficientes técnicos dos insumos domésticos por setor e $\left(\hat{X}^{N}\right)^{-1}$ é o vetor $X$ diagonalizado e invertido.

Para estimar as tabelas regionais $U^{R}$ e $V^{R}$, foi necessário construir o vetor $X^{R}$ dos valores da produção estadual por setor de atividade para o ano de 1995. Para a construção do vetor $X^{R}$ utilizaram-se dados de instituições como IPARDES (1997a), Sindicato da Indústria de Carnes e Derivados no Estado do Paraná - SINDICARNES ${ }^{12}$, Associação de Produtores de Álcool e Açúcar do Estado do Paraná - ALCOPAR ${ }^{13}$, Associação Brasileira das Industrias de Óleos Vegetais - ABIOVE $^{14}$ e Secretaria de Estado da Fazenda (Paraná, 1997). As informações para o setor Agropecuária foram retiradas do Censo Agropecuário 1995-1996 do Brasil e do Paraná (IBGE, 1998a e 1998b) e para o setor Extrativa Mineral do Anuário Mineral Brasileiro-1996, ano-base 1995 (Brasil, 1998).

12 SINDICARNES (Abate de animais sob inspeção federal no Paraná, Curitiba). Comunicação pessoal, 1998.

${ }^{13}$ ALCOPAR (Evolução da produção de açúcar e álcool no Paraná, Maringá - PR). Comunicação pessoal, 1999.

${ }^{14}$ ABIOVE (Capacidade instalada de processamento de oleaginosas 1995, São Paulo). Comunicação pessoal, 1998. 
O trabalho de Considera e Medina (1998) foi utilizado uma vez que este traz o PIB setorial por unidade da Federação para o período 1985/96. Assim, determinou-se a participação do PIB do Paraná no nacional para calcular o vetor de valores setoriais da produção para o Estado, $X^{R}$, tomando como base os valores da matriz de insumoproduto do Brasil. A distribuição dos valores obtidos para a indústria e serviços foi feita com base na participação dos gêneros de atividades no PIB paranaense (IPARDES, 1997a).

A partir daí, o procedimento foi calcular a participação de cada elemento das linhas de $V^{N}$ em $X^{N}$. O vetor $X^{N}$ originou-se da Tabela de Produção nacional. Assim, com base na matriz de participações obtida, o vetor $X^{R}$ foi distribuído entre os produtos dos vários setores da economia estadual, resultando na tabela $V^{R}$ e no vetor $Q^{\prime R}(I x p)$, este último representando a produção estadual por produto. Posteriormente, calculou-se $D^{R}(s \times p)$ que é dada por:

$$
D^{R}=V^{R}\left(\hat{Q}^{\prime R}\right)^{-1}
$$

em que $D^{R}$ é a matriz de coeficientes técnicos de produto para o Paraná e;

$$
\left(\hat{Q}^{\mathrm{R} R}\right)^{-1} \text { é o vetor } Q^{\prime R} \text { diagonalizado e invertido }(p \times p) \text {. }
$$

As informações obtidas até o momento permitiram calcular os coeficientes locacionais setoriais, descritos na seção 4.1 .1 , os quais pré-multiplicam a matriz $B^{N}$, para determinar $B^{R}$, a matriz dos coeficientes técnicos dos insumos para o Paraná.

Finalmente, a matriz $A^{R}(s x s)$ dos coeficientes técnicos de insumos diretos foi estimada por:

$$
A^{R}=D^{R} B^{R}
$$

A expressão (4.5) traz implícito o enfoque setor-setor, tecnologia baseada na indústria, adotado neste estudo. Este enfoque é usado na grande maioria dos estudos que utilizam a análise de insumo-produto, por permitir que se diferencie a tecnologia de produção dos diversos produtos.

A partir da matriz $A^{R}$, obteve-se a matriz dos coeficientes técnicos de insumo diretos e indiretos para o Paraná, ou matriz inversa de Leontief, $L^{R}(s \times s)$ : 


$$
L^{R}=\left(I-A^{R}\right)^{-1}
$$

Essa matriz é, também, chamada de matriz dos impactos diretos e indiretos, por permitir verificar o impacto na produção, renda e emprego para uma dada variação na demanda final.

Os elementos $Z, M, W, X^{\mathrm{R}}, Y, M F$ e $X^{R}$ do Quadro 4.3 representam, de forma simplificada, a estrutura da matriz de insumo-produto regional construída nesta pesquisa. A matriz $Z$ é a matriz de transações intersetoriais ( $x \boldsymbol{x}$ ), contendo a demanda ou consumo setorial intermediário.

As importações intermediárias $(M)$ estão subdivididas, no presente estudo, em importações do resto do Brasil $(M R B)$ e importações do exterior (MEX). As primeiras foram obtidas por diferença da seguinte forma:

$$
M R B=\widetilde{U}^{R}-U^{R}
$$

em que $\bar{U}^{R}=B^{N} * \hat{X}^{R}$ representa quanto o Paraná usou de insumos nacionais e $U^{R}=B^{R} * \hat{X}^{R}$ representa quanto o Paraná usou de insumos produzidos no próprio Estado.

Para as importações do exterior, os impostos indiretos líquidos (IIL) e os componentes do valor adicionado $(W)$, a saber, remunerações, excedente operacional bruto, outros impostos sobre a produção e outros subsídios sobre a produção, foram utilizadas as proporções do Brasil.

A demanda final $(Y)$ é composta pela formação bruta de capital fixo, exportações para o exterior, exportações para o resto do Brasil, variação de estoque, consumo do governo e consumo das famílias. As exportações para o exterior foram estimadas com base em IPARDES (1997b), ao passo que os demais componentes da demanda, exceto a variação de estoque, e a dummy financeiro foram calculados a partir das proporções do Brasil. A variação de estoque foi obtida por resíduo.

$O$ vetor $M F$ representa as importações finais de bens e serviços realizadas na economia em determinado ano e foi estimado como o vetor $M$.

A tabela de produção, $V^{N}$, estimada para o Paraná foi, posteriormente, dividida nas regiões-pólo componentes deste estudo. Inicialmente, foi necessário 
construir o vetor $X$ para cada pólo regional e, em seguida, foram aplicados os mesmos procedimentos descritos acima, para construir as tabelas de produção e de uso.

Para obter as importações de insumos que cada região-pólo faz do resto do Paraná, utilizou-se o mesmo procedimento descrito pela equação (4.7). A distribuição dessas importações foi feita por meio de matrizes de coeficientes técnicos entre regiões, expressas por $b_{i j}{ }^{P R}-b_{i j}{ }^{R}$. Esses coeficientes foram multiplicados pela participação de produção de cada região-pólo no resto da economia excluindo, sempre, uma região. Dessa forma, foi possível obter as matrizes dos fluxos de insumos entre regiões.

Os componentes da demanda final foram distribuídos, entre as regiões-pólo, utilizando-se os mesmos procedimentos descritos acima. Desta forma, foi possível construir o sistema inter-regional, conforme descrito na seção 3.5 do capítulo 3 .

\subsection{Paraná e as divisões em pólos regionais}

A Tabela 2.4 serviu de base para a definição das regiões-pólo que serão adotadas neste estudo, uma vez que as microrregiões foram agregadas em torno das MRHs cujo Produto Interno Bruto já indicava serem as quatro mais importantes no Estado. Desse modo, observa-se que o Pólo Regional de Curitiba concentrou a maior parte do PIB paranaense no ano de 1995, 40,09\%. O segundo pólo mais importante foi o Pólo Regional de Londrina que respondeu com 28,77\% do total do PIB estadual, enquanto o Pólo Regional de Ponta Grossa e o Pólo Regional de Cascavel produziram, respectivamente, $15,66 \%$ e $15,48 \%$ do PIB. Assim, as regiões-pólo que nortearão este estudo estão descritas abaixo (Tabela 4.1) e ilustrados na Figura 4.1.

a) Pólo Regional de Curitiba: Curitiba, Litoral Paranaense, Alto Ribeira, Alto Rio Negro Paranaense, Campos de Lapa e São Mateus do Sul;

b) Pólo Regional de Londrina: Norte Velho de Jacarezinho, Algodoeira de Assaí, Norte Novo de Londrina, Norte Novo de Maringá, Norte Novíssimo de Paranavaí, Norte Novo de Apucarana, Norte Novíssimo de Umuarama e Campo Mourão; 
Tabela 4.1. Constituição das regiões-pólo do Paraná, conforme a distribuição do PIB $_{\mathrm{cf}}$ Paraná, 1995.

\begin{tabular}{|c|c|c|c|c|}
\hline Microrregiões & $\begin{array}{r}\text { Agropecuária } \\
\text { (\%/total) }\end{array}$ & $\begin{array}{l}\text { Indústria } \\
\text { (\%/total) }\end{array}$ & $\begin{array}{l}\text { Serviços } \\
\text { (\%/total) }\end{array}$ & $\begin{array}{r}\text { PIB }_{\text {cf }} \\
\text { (\%/total) }\end{array}$ \\
\hline Pólo Regional de Curitiba & $\mathbf{7 , 5 8}$ & 53,43 & 40,79 & 40,09 \\
\hline Curitiba & 2,90 & 49,96 & 36,68 & 36,10 \\
\hline Litoral Paranaense & 0,32 & 1,19 & 2,11 & 1,58 \\
\hline Alto Ribeira & 0,22 & 0,15 & 0,16 & 0,17 \\
\hline Alto Rio Negro Paranaense & 0,60 & 0,15 & 0,24 & 0,26 \\
\hline Campos de Lapa & 2,76 & 1,39 & 1,16 & 1,45 \\
\hline São Mateus do Sul & 0,76 & 0,59 & 0,44 & 0,53 \\
\hline Pólo Regional de Ponta Grossa & 21,74 & 15,99 & 13,96 & 15,66 \\
\hline Campos de Jaguariaíva & 1,31 & 2,82 & 0,87 & 1,53 \\
\hline Campos de Ponta Grossa & 6,51 & 8,14 & 5,17 & 5,96 \\
\hline Colonial de Irati & 2,08 & 0,87 & 1,14 & 1,19 \\
\hline Alto Ivaí & 0,87 & 0,22 & 0,45 & 0,44 \\
\hline Norte Velho de Wenceslau Braz & 1,89 & 0,52 & 0,98 & 0,96 \\
\hline Pitanga & 1,28 & 0,30 & 0,71 & 0,66 \\
\hline Campos de Guarapuava & 5,61 & 2,42 & 3,05 & 3,21 \\
\hline Médio Iguaçú & 2,19 & 1,71 & 1,58 & 1,70 \\
\hline Pólo Regional de Londrina & 43,30 & 21,45 & 29,21 & 28,77 \\
\hline Norte Velho de Jacarezinho & 5,38 & 1,79 & 2,79 & 2,84 \\
\hline Algodoeira de Assaí & 1,46 & 0,39 & 0,60 & 0,65 \\
\hline Norte Novo de Londrina & 9,13 & 8,51 & 9,55 & 9,17 \\
\hline Norte Novo de Maringá & 4,09 & 3,57 & 5,15 & 4,52 \\
\hline Norte Novissimo de Paranavaí & 4,39 & 1,24 & 2,10 & 2,15 \\
\hline Norte Novo de Apucarana & 3,49 & 2,00 & 2,34 & 2,40 \\
\hline Norte Novíssimo de Umuarama & 6,45 & 22,2 & 3,18 & 3,34 \\
\hline Campo Mourão & 8,89 & 1,71 & 3,50 & 3,70 \\
\hline Pólo Regional de Cascavel & 27,39 & 9,14 & 16,04 & 15,48 \\
\hline$\overline{\text { Extremo-Oeste Paranaense }}$ & 19,87 & 6,57 & 11,88 & 11,35 \\
\hline Sudoeste Paranaense & 7,51 & 2,56 & 4,16 & 4,13 \\
\hline
\end{tabular}

Fonte: IPARDES (1998).

c) Pólo regional de Ponta Grossa: Campos de Jaguariaiva, Campos de Ponta Grossa, Colonial de Irati, Alto Ivaí, Norte Velho de Wenceslau Braz, Pitanga, Campos de Guarapuava e Médio Iguaçú e

d) Pólo Regional de Cascavel: Extremo-Oeste Paranaense e Sudoeste Paranaense. 


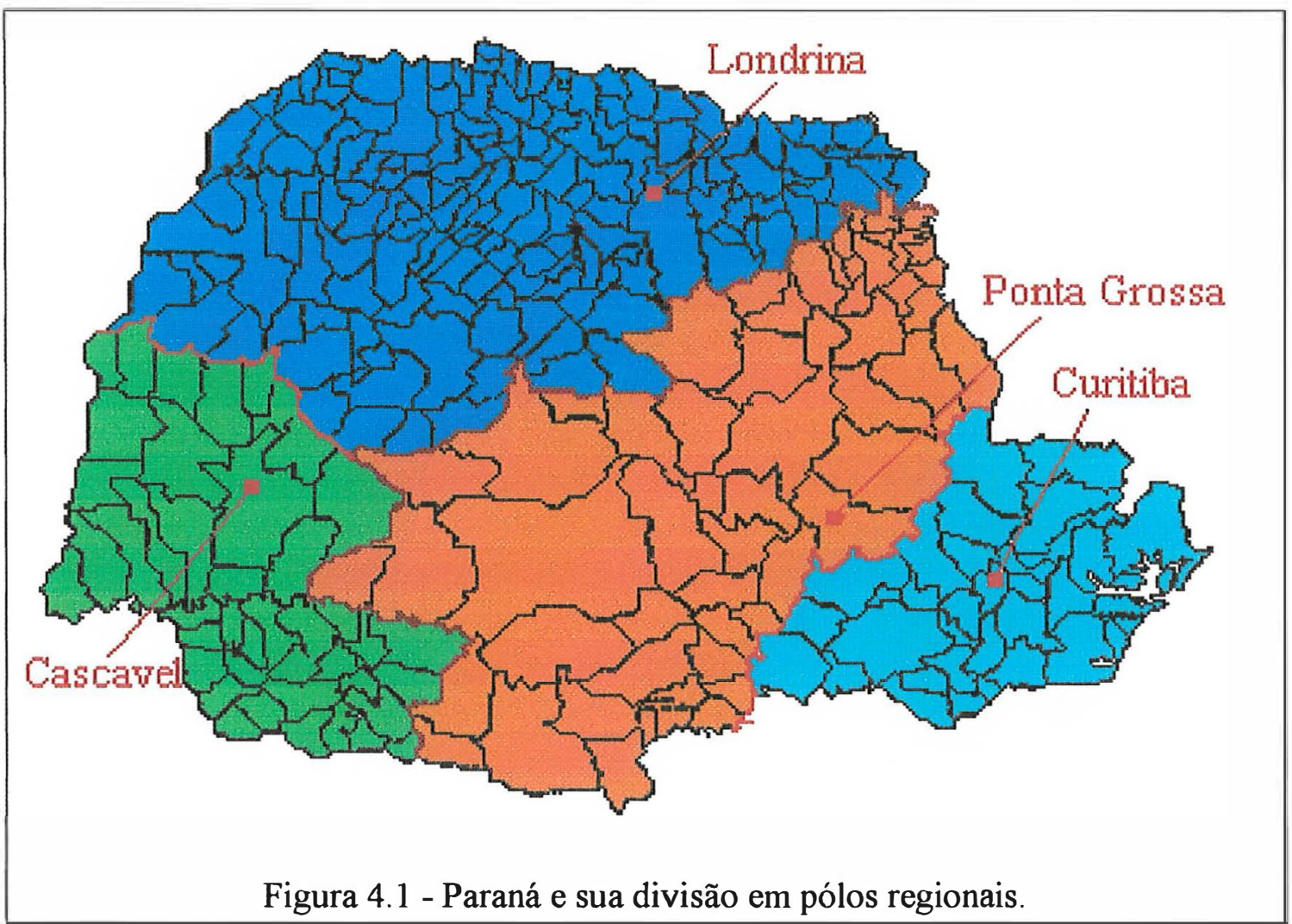




\section{MÉTODOS DE ANÁLISE DA ESTRUTURA PRODUTIVA}

O propósito deste capítulo é de apresentar os métodos de análises que serão utilizados no presente estudo. Trata, portanto, da seleção das técnicas a serem aplicadas para analisar a estrutura produtiva paranaense, a partir da matriz de insumo-produto inter-regional do Paraná.

Inicialmente, há uma apresentação dos índices de encadeamentos para frente e para trás de Rasmussen (1956) e Hirschman (1958) a fim de determinar os setores que teriam o maior poder de encadeamento dentro da economia. Esses índices são complementados pelo método do campo de influência proposto por Sonis e Hewings (1989 e 1994) que permite determinar as relações entre os setores que são mais importantes dentro do processo produtivo. Na seqüência, é feita uma descrição do modelo GHS de Guilhoto et al. (1996). Essa técnica permite identificar o grau dos impactos na demanda final em determinadas regiões ou setores, bem como dimensionar as interações entre setores e regiões em termos de valor da produção. A técnica matriz de intensidade também foi empregada com o intuito de comparar as estruturas econômicas de cada região a ser estudada. Finalmente, apresenta-se a técnica de interações sinergéticas entre regiões, desenvolvida por Sonis et al. (1997), a qual permite classificar os tipos de interações sinergéticas e possibilita examinar a estrutura das relações comerciais entre regiões. 


\section{1 Índices de ligações e setores-chave na economia}

O conceito de ligações, originalmente introduzido por Hirschman (1958), atraiu a atenção de estudiosos como um instrumento de identificação de setorẹs-chave para analisar e planejar o desenvolvimento industrial. $O$ argumento básico é que a interdependência entre as atividades produtivas são características da produção moderna e que o nível e a direção desta interdependência indicam a capacidade potencial de cada setor para estimular outros setores. As atividades que apresentam ligações mais altas são consideradas setores-chave para desencadear um rápido crescimento da produção, renda e emprego. Embora o conceito diga respeito às economias desenvolvidas, ele tem sido usado extensivamente como programas adequados em economias regionais para o desenvolvimento industrial.

A definição de critérios que permitem identificar os setores que apresentam maior capacidade de difundir seus efeitos sobre o sistema econômico e propiciar maior dinamismo à economia tem merecido atenção de muitos estudiosos na literatura econômica. Em particular, Guilhoto et al. (1994), salientam que existe consenso sobre a importância das ligações interindustriais de uma economia na determinação de estímulos ao crescimento econômico, mas parece haver pouco acordo com relação à identificação de setores-chave ou pólos de crescimento. Segundo esses autores,

"parte da confusão tem sua origem na dificuldade de se identificar quais seriam os setores que contribuem acima da média para a economia, tanto dentro de uma perspectiva ex-post como ex-ant. Contudo, parece haver um consenso de que o processo de transformação econômica é freqüentemente estimulado por um número relativamente pequeno de setores, mesmo se a economia como um todo acabe sofrendo mudanças" (Guilhoto et al. 1994, p.287). 


\subsection{1 Índices de Rasmussen-Hirschman}

Considerando a estrutura interna da economia, baseada no modelo de insumo-produto, e seguindo Rasmussen (1956), Hirschman (1958) e Guilhoto et al. (1994), podem-se determinar os setores que teriam o maior poder de encadeamento dentro da economia, ou seja, pode-se calcular os índices de ligações para trás, que mostram o quanto um setor demanda dos outros setores, e os índices de ligações para frente, que informam o quanto um setor é demandado pelos outros. Os valores maiores do que 1 , tanto dos índices de ligações para trás como para frente, indicam setores acima da média e, portanto, considerados setores-chave para o crescimento da economia.

Desse modo, com base na equação $B=(I-A)^{-1}$, define-se $b_{i j}$ como um elemento da matriz inversa de Leontief $B$, sendo $B^{*}$ a média de todos os elementos de $B$ e $\boldsymbol{B}_{*_{j}}$ e $\boldsymbol{B}_{i^{\star}}$ sendo, respectivamente, a soma de uma coluna e de uma linha típica de $\boldsymbol{B}$. Assim, tem-se:

Índices de ligações para trás:

$\mathrm{IRHT}=\left[\boldsymbol{B}_{*_{j}} / n\right] / \boldsymbol{B}^{*}$

Índices de ligações para frente:

$\mathrm{IRHF}=\left[\boldsymbol{B}_{i^{*}} / n\right] / \boldsymbol{B}^{*}$

Os índices de ligações de Rasmussen-Hirschman, carregam consigo a crítica de que não levam em consideração os diferentes níveis de produção em cada setor da economia. Com o intuito de corrigir essa deficiência, foram desenvolvidos diferentes enfoques para o cálculo de índices de ligações intersetoriais, como será visto na seção 5.3 .

\subsubsection{Campo de influência.}

O campo de influência (Sonis e Hewings, 1989 e 1994) permite verificar como se distribuem as mudanças dos coeficientes diretos no sistema econômico como um todo, possibilitando, desse modo, determinar que relações entre os setores são mais importantes dentro do processo produtivo. Assim, o campo de influência se apresenta 
como uma análise complementar à dos índices de ligações de Hirschman-Rasmussen, uma vez que estes, apesar de avaliarem a importância do setor em termos dos seus impactos no sistema como um todo, não permitem visualizar facilmente quais os coeficientes que, alterados, teriam um maior impacto no sistema como um todo (Guilhoto et al. 1994).

O procedimento para o cálculo do campo de influência requer a matriz de coeficientes técnicos de produção, $A=\left|a_{i j}\right|$, e a definição de uma matriz de variações incrementais nos coeficientes diretos de insumo, $E=\left|\varepsilon_{i j}\right|$. As correspondentes matrizes inversas de Leontief são dadas por $B=(I-A)^{-1}=\left|b_{i j}\right|$ e por $\boldsymbol{B}(\varepsilon)=[I-A-\varepsilon]^{-1}=\left|b_{i j}(\varepsilon)\right|$. De acordo com Sonis e Hewings (1989 e 1994), que desenvolveram a metodologia do campo de influência, caso a variação tecnológica seja pequena e só ocorra num coeficiente direto, isto é:

$$
\varepsilon_{i j}= \begin{cases}\varepsilon & i=i_{1}, j=j_{1} \\ 0 & i \neq i_{1} \text { ou } j \neq j_{1}\end{cases}
$$

tem-se que o campo de influência desta variação pode ser aproximado pela expressão:

$$
F\left(\varepsilon_{i j}\right)=\frac{\left[B\left(\varepsilon_{i j}\right)-B\right]}{\varepsilon_{i j}}
$$

em que $F\left(\varepsilon_{i j}\right)$ é uma matriz ( $\left.n \times n\right)$ do campo de influência do coeficiente $a_{i j}$.

Para se determinar quais são os coeficientes que possuem o maior campo de influência, associa-se a cada matriz $F\left(\varepsilon_{i j}\right)$ um valor que é dado por:

$$
S_{i j}=\sum_{k=l}^{n} \sum_{l=1}^{n}\left[f_{k l}\left(\varepsilon_{i j}\right)\right]^{2}
$$

Desse modo, os coeficientes diretos que possuem os maiores valores de $S_{i j}$ são aqueles com o maior campo de influência dentro da economia como um todo. 


\subsection{Matriz de Intensidade}

A técnica do campo de influência foi, recentemente, expandida por Sonis et al. (1997) e Sonis e Hewings (1999) para introduzir a noção de intensidade, a qual pode ser visualizada por meio de matriz tri-dimensional.

Nessa abordagem, deriva-se a matriz do produto dos multiplicadores (MPM) que revela a hierarquia das ligações para trás e para a frente, delineando a topografia econômica a ela associada e refletindo a estrutura do cruzamento associado à MPM.

Mais especificamente, a MPM pode ser derivada a partir dos multiplicadores das linhas e das colunas da matriz inversa de Leontief $(B)$. Dessa forma, os vetores linha e coluna dos multiplicadores coluna e linha podem ser representados, respectivamente, pelas seguintes expressões:

$$
M_{c}(B)=\left(\begin{array}{llll}
B_{* 1} & B_{* 2} & \ldots & B_{*_{n}}
\end{array}\right) \quad \text { e } \quad M_{l}(B)=\left(\begin{array}{c}
B_{1^{*}} \\
B_{2^{*}} \\
\vdots \\
B_{n^{*}}
\end{array}\right)
$$

Assumindo $b_{* *}$ como a soma de todos os elementos da matriz inversa de Leontief, denominada de intensidade global da matriz, como:

$$
b_{* *}=\sum_{i=1}^{n} \sum_{j=1}^{n} b_{i j}
$$

pode-se definir a matriz de intensidade ou a MPM como:

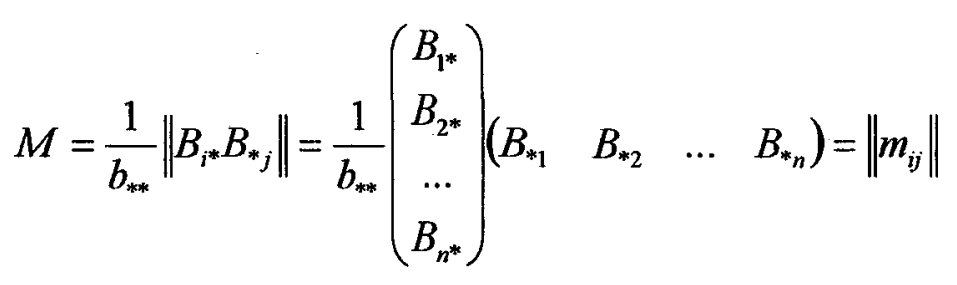

De acordo como os autores citados acima, a estrutura da matriz $M$ pode ser melhor entendida do seguinte modo: considere os maiores multiplicadores coluna e linha da inversa de Leontief, $B_{*_{j}}$ e $B_{i^{*}}$, e o elemento $m_{i_{0} j_{0}}=\frac{1}{b_{* *}} B_{i_{0}{ }^{*}} B_{*_{j_{0}}}$, localizado na célula $\left(i_{0}, j_{0}\right)$ da matriz $M$. Assumindo que todas as linhas da matriz $M$ são proporcionais à $i_{0}^{\text {th }}$ 
linha e os elementos desta linha são maiores do que os elementos correspondentes de todas as outras linhas e que a mesma propriedade é aplicada à $j_{0}^{\text {th }}$ de $M$, tem-se que o elemento localizado na célula $\left(i_{0}, j_{0}\right)$ define o centro do maior cruzamento dentro da matriz $M$. Se esse cruzamento for excluído de $M$, o segundo maior cruzamento pode ser identificado, e assim sucessivamente.

A organização das linhas e colunas de $M$ pode ser feita de modo que os centros dos cruzamentos correspondentes apareçam na diagonal principal. Nesse caso, a matriz $M$ mostrará uma topografia econômica descendente, baseada na seqüência de ordenação por tamanho dos multiplicadores coluna e linha. Esse arranjo, também, revela a hierarquia descendente dos índices para frente e para trás de Rasmussen-Hirschmam (Sonis et al., 1997 e Sonis e Hewings, 1999). Inspecionando-se a parte da topografia com esses índices maiores do que 1 será possível identificar os setores-chave na economia. Todavia, a construção da matriz $M$ é importante pois permite explorar de forma consistente e complementar a estrutura desses índices tradicionais.

A matriz $M$ pode ser construída para diferentes regiões ou para a mesma região em diferentes pontos no tempo, o que cria a possibilidade de estabelecer uma classificação sistemática destas economias. Assim, adotando como mumeraire ou base a ordenação por tamanho dos multiplicadores coluna e linha de certa economia ou de dado período, a topografia econômica pode ser visualmente comparada: desvios da topografia descendente retratada pela economia tomada como base refletirão diferenças na estrutura econômica entre as regiões ou entre períodos distintos em uma mesma região. Estas diferenças mostrarão, no caso de estudos com mais de uma região, variação no conjunto de indústrias das regiões, variação no grau da intermediação intraregional e variação na tecnologia.

Considerando uma região em pontos diferentes no tempo, as alterações poderão refletir variação no $m i x$ de indústrias, variações no grau de ligações setoriais, bem como mudanças na tecnologia ocorridas nesta economia. 
A topografia econômica resultante da MPM, embora não substitua outras técnicas, constitui ferramenta complementar na definição preliminar de diferenças e similaridades entre economias ou entre diferentes períodos da mesma economia.

Finalmente, cabe registrar que Sonis et al. (s.n.t.) aplicaram a análise da MPM para as quatro maiores economias metropolitanas da China e que Sonis e Hewings (/1999?/) usaram a mesma técnica para interpretar os multiplicadores à esquerda e à direita de Miyazawa em termos de retornos multi-regionais.

\section{3 Índice Puro de Ligações: modelo GHS}

Os índices de ligação de Hirschman e Rasmussen não levam em consideração os diferentes níveis de produção em cada setor da economia e, portanto, constituíram-se num foco contínuo de aperfeiçoamento, iniciado por Cella (1984), seguido por Clements (1990) e Guilhoto et al. (1994). A abordagem mais recente, desenvolvida por Guilhoto et al. (1996), corrige um erro de decomposição dos autores precedentes, além de aprimorar a versão inicial de Guilhoto et al. (1994).

O novo índice puro de ligações, daqui por diante denominado de GHS, será utilizado neste estudo uma vez que esta técnica permite identificar os graus dos impactos na demanda final em determinadas regiões ou setores, bem como dimensionar as interações entre setores e regiões em termos de valor da produção.

O modelo GHS pode ser descrito de forma resumida ${ }^{15}$ considerando-se um sistema de insumo-produto composto por duas regiões e representado pelo bloco de matriz, $A$, de insumos diretos:

$$
A=\left[\begin{array}{cc}
A_{\ddot{j}} & A_{j r} \\
A_{r j} & A_{r r}
\end{array}\right]
$$

em que $A_{j j}$ e $A_{r r}$ representam matrizes quadradas de insumos diretos dentro da primeira e segunda região, respectivamente, e $A_{j r}$ e $A_{r j}$ são matrizes retangulares dos insumos diretos adquiridos pela segunda região e vice versa.

\footnotetext{
${ }^{15}$ Para uma descrição detalhada do modelo GHS, ver Guilhoto et al. (1996).
} 
Da equação (5.9) pode-se chegar à seguinte expressão:

$$
B=(I-A)^{-1}=\left[\begin{array}{ll}
B_{i j} & B_{j r} \\
B_{r j} & B_{r r}
\end{array}\right]=\left[\begin{array}{cc}
\Delta_{i j} & 0 \\
0 & \Delta_{r r}
\end{array}\right]\left[\begin{array}{cc}
\Delta_{j} & 0 \\
0 & \Delta_{r}
\end{array}\right]\left[\begin{array}{cc}
I & A_{j r} \Delta_{r} \\
A_{r j} \Delta_{j} & I
\end{array}\right]
$$

em que os componentes de (5.10) são definidos como:

$$
\begin{aligned}
& \Delta_{j}=\left(I-A_{j j}\right)^{-1} \\
& \Delta_{r}=\left(I-A_{r r}\right)^{-1} \\
& \Delta_{i j}=\left(I-\Delta_{j} A_{j r} \Delta_{r} A_{r j}\right)^{-1} \\
& \Delta_{r r}=\left(I-\Delta_{r} A_{j} \Delta_{j} A_{j r}\right)^{-1}
\end{aligned}
$$

Pela decomposição de (5.10), é possível verificar como ocorre o processo de produção na economia, bem como derivar uma série de multiplicadores e de ligações da estrutura produtiva. Assim, a matriz

$$
\left[\begin{array}{cc}
\Delta_{i j} & 0 \\
0 & \Delta_{r r}
\end{array}\right]
$$

pode ser interpretada com o multiplicador externo de Miyazawa (1976) para a região $j \mathrm{e}$ o resto da economia, $r$, enquanto a matriz

$$
\left[\begin{array}{cc}
\Delta_{j} & 0 \\
0 & \Delta_{r}
\end{array}\right]
$$

representa o multiplicador interno de Miyazawa (1976) para a região $j$ e o resto da economia, $r$.

Na matriz

$$
\left[\begin{array}{cc}
I & A_{j r} \Delta_{r} \\
A_{r j} \Delta_{j} & I
\end{array}\right]
$$

a primeira linha separa a demanda final pela sua origem, isto é, diferencia a demanda final interna da região $(I)$ da demanda final externa da região $\left(A_{j r} \Delta_{r}\right)$. A mesma idéia aplica-se à segunda linha.

Partindo-se da formulação de Leontief,

$$
X=(I-A)^{-1} Y \text {, }
$$


e utilizando-se as informações contidas em (5.10), deriva um conjunto de índices que pode ser usado para:

a) classificar as regiões de acordo com sua importância na economia e

b) identificar como o processo de produção ocorre na economia.

Da expressão (5.10) e (5.18), obtém-se:

$$
\left[\begin{array}{l}
X_{j} \\
X_{r}
\end{array}\right]=\left[\begin{array}{cc}
\Delta_{i j} & 0 \\
0 & \Delta_{r r}
\end{array}\right]\left[\begin{array}{cc}
\Delta_{j} & 0 \\
0 & \Delta_{r}
\end{array}\right]\left[\begin{array}{cc}
I & A_{j r} \Delta_{r} \\
A_{r j} \Delta_{j} & I
\end{array}\right]\left[\begin{array}{l}
Y_{j} \\
Y_{r}
\end{array}\right]
$$

que, pela multiplicação dos três últimos termos do lado direito de (5.19), conduz a:

$$
\left[\begin{array}{l}
X_{j} \\
X_{r}
\end{array}\right]=\left[\begin{array}{cc}
\Delta_{i j} & 0 \\
0 & \Delta_{r r}
\end{array}\right]\left[\begin{array}{c}
\Delta_{j} Y_{j}+\Delta_{j} A_{j r} \Delta_{r} Y_{r} \\
\Delta_{r} A_{r j} \Delta_{j} Y_{j}+\Delta_{r} Y_{r}
\end{array}\right]
$$

em que $A_{j r} \Delta_{r} Y_{r}$ é o impacto direto da demanda final do resto da economia sobre a região $j$, isto é, fornece o nível de exportação da região $j$ necessário para satisfazer o nível de produção do resto da economia dada uma demanda final $Y_{r}$ e $A_{r j} \Delta_{j} Y_{j}$ é o impacto direto da demanda final da região $j$ sobre o resto da economia, ou seja, indica o nível de exportações do resto da economia que é necessário para satisfazer a necessidade de produção da região $j$ para uma determinada demanda final $Y_{j}$.

A partir de (5.20), tem-se a nova definição para o índice puro de ligações para trás $(P B L)$ e para frente $(P F L)$, expressos por:

$$
\begin{aligned}
& P B L=\Delta_{r} A_{j} \Delta_{j} Y_{j} \\
& P F L=\Delta_{j} A_{j r} \Delta_{r} Y_{r}
\end{aligned}
$$

$O P B L$ indica o impacto puro do valor da produção total da região $j$ sobre o resto da economia $\left(\Delta_{j} Y_{j}\right)$, isto é, o impacto que é livre da demanda de insumos que a região $j$ produz para a própria região $j$ e dos retornos do resto da economia para a região $j$ e vice versa.

O PFL indica o impacto puro do valor da produção total do resto da economia $\left(\Delta_{r} Y_{r}\right)$ sobre a região $j$. Cabe salientar que, tanto o $P B L$ quanto o $P F L$, são expressos em valores correntes e, portanto, podem ser somados. Nesse sentido, o índice puro total das ligações $(P T L)$ de cada setor na economia é dado por: 


$$
P T L=P B L+P F L
$$

Por fim, multiplicando-se os dois termos do lado direito de (5.20) tem-se:

$$
\left(\begin{array}{c}
X_{j} \\
X_{r}
\end{array}\right)=\left(\begin{array}{c}
\Delta_{i j} \Delta_{j} Y_{j}+\Delta_{i j} \Delta_{j} A_{j r} \Delta_{r} Y_{r} \\
\Delta_{r r} \Delta_{r} A_{r j} \Delta_{j} Y_{j}+\Delta_{r r} \Delta_{r} Y_{r}
\end{array}\right)=\left(\begin{array}{c}
X_{j}^{j}+X_{j}^{r} \\
X_{r}^{j}+X_{r}^{r}
\end{array}\right)
$$

$O$ total da produção da região $j$, representado em (5.24), pode ser dividido em dois componentes:

$$
X_{j}^{j}=\Delta_{i j} \Delta_{j} Y_{j}
$$

$$
X_{j}^{r}=\Delta_{j j} \Delta_{j} A_{j r} \Delta_{r} Y_{r}
$$

em que o $X_{j}^{j}$ fornece o nível total de produção da região $j$ que é devido à demanda final da região $j$ e $X_{j}^{r}$ quantifica o nível de produção total da região $j$ proporcionado pela demanda final do resto da economia. Da mesma forma, o nível total de produção no resto da economia pode, também, ser separado em dois componentes:

$$
\begin{aligned}
& X_{r}^{j}=\Delta_{r r} \Delta_{r} A_{r j} \Delta_{j} Y_{j} \\
& X_{r}^{r}=\Delta_{r r} \Delta_{r} Y_{r}
\end{aligned}
$$

em que o $X_{r}^{j}$ fornece o nível total de produção no resto da economia que é devido à demanda final da região $j$ e $X_{r}^{r}$ quantifica o nível de produção total no resto da economia proporcionado pela demanda final do resto da economia.

Esta metodologia fornece um poderoso instrumental analítico tendo em vista a integração dos principais métodos usados, possibilitando, desta forma, a decomposição dos impactos entre as diferentes regiões, além de permitir a análise da economia, dada a sua estrutura produtiva.

O modelo GHS já foi aplicado por Guilhoto et al. (1997), Montoya (1998), Crocomo (1998) e Montoya e Guilhoto (1998). 


\subsection{Interações sinergéticas entre regiões ${ }^{16}$}

Esta metodologia, desenvolvida por Sonis et al. (1997), permite classificar os tipos de interações sinergéticas entre regiões e possibilita examinar, por meio das interdependências internas e externas, dadas pelas ligações, a estrutura das relações comerciais entre duas regiões. Ela está baseada num sistema de insumo-produto partilhado e utiliza técnicas que produzem multiplicadores à esquerda e à direita da inversa de Leontif, dentro de um preestabelecido par de combinação hierárquica dos subsistemas de ligações econômicas.

Considerando-se um sistema de insumo-produto representado pelo bloco de matrizes, $A$, de insumos diretos:

$$
A=\left[\begin{array}{ll}
A_{11} & A_{12} \\
A_{21} & A_{22}
\end{array}\right]
$$

em que $A_{11}$ e $A_{22}$ representam matrizes quadradas de insumos diretos dentro da primeira e segunda regiões, respectivamente, e $A_{12}$ e $A_{21}$ são matrizes retangulares dos insumos diretos adquiridos pela segunda região e vice versa. É possível interpretar a matriz $A$ como um sistema de duas regiões em que a segunda região representa o resto da economia menos a primeira região.

A construção dos blocos de pares de combinações hierárquicas dos subsistemas de ligações intra e inter-regionais, num sistema de insumo-produto, é dada pelas matrizes $A_{11}, A_{12}, A_{21}$ e $A_{22}$, as quais correspondem a quatro blocos básicos de matrizes:

$$
A_{11}=\left[\begin{array}{cc}
A_{11} & 0 \\
0 & 0
\end{array}\right] ; \quad A_{12}=\left[\begin{array}{cc}
0 & A_{12} \\
0 & 0
\end{array}\right] ; \quad A_{21}=\left[\begin{array}{cc}
0 & 0 \\
A_{21} & 0
\end{array}\right] ; \quad A_{22}=\left[\begin{array}{cc}
0 & 0 \\
0 & A_{22}
\end{array}\right]
$$

A decomposição do bloco de matrizes (5.29) pode ser feita por meio da soma de dois blocos de matrizes, sendo cada um deles a soma dos blocos de matrizes de (5.30).

\footnotetext{
${ }^{16}$ A presente metodologia está baseada em Sonis et al. (1997) e Guilhoto et al. (1999). No primeiro artigo os autores descrevem, passo a passo, a técnica de interações sinergéticas entre regiões, enquanto o segundo faz uma aplicação para o Brasil usando duas regiões, Nordeste e resto do Brasil.
} 
Por meio da decomposição de (5.29), podem-se identificar 14 tipos de pares de combinações hierárquicas dos subsistemas econômicos, conforme mostrado na Quadro 5.2.

\subsubsection{Multiplicadores regionais internos}

Nesta seção, é apresentado um conjunto de multiplicadores regionais internos, derivados das matrizes inversas, as quais são blocos construídos das interações sinergéticas entre os subsistemas econômicos e estão sintetizadas na Quadro 5.1. Contudo, alguns comentários são necessários. Os números em destaque neste quadro, referem-se às entradas.

1. As matrizes $B_{1}=\left(I-A_{11}\right)^{-1}$ e $B_{2}=\left(I-A_{22}\right)^{-1}$ representam os multiplicadores internos de Miyazawa da primeira e segunda região, respectivamente, e mostram os efeitos de propagação interindustrial dentro de cada região, enquanto as matrizes $A_{21} B_{1}, B_{1} A_{12}, A_{12} B_{2}$ e $B_{2} A_{21}$ retratam os efeitos sobre a produção nas duas regiões.

2. As expressões

$S_{1}=I-A_{11}-A_{12} B_{2} A_{21}, \quad S_{2}=I-A_{22}-A_{21} B_{1} A_{12}$

são, usualmente, referidas como os complementos de Schur. De (5.26), pode-se derivar

$$
\left[\begin{array}{cc}
I-A_{11} & -A_{12} \\
-A_{21} & I-A_{11}
\end{array}\right]=\left[\begin{array}{cc}
I & D_{1} A_{12} B_{2} \\
0 & D_{2}
\end{array}\right]\left[\begin{array}{cc}
B_{1} & 0 \\
A_{21} B_{1} & I
\end{array}\right]
$$

em que (5.27) é referida por Sonis et al. (1997) como a fórmula inversa de SchurBanachiewicz e fornece as bases para a classificação das interações sinergéticas entre as ligaçõos dos subsistemas econômicos.

As matrizes $D_{1}$ e $D_{2}$ dos complementos de Schur (5.26) são referidas como as inversas de Schur para a primeira e segunda regiões, respectivamente. Elas representam a inversa de Leontief ampliada para uma região e revelam a influência econômica induzida da outra região, ou seja, as inversas de Schur representam os efeitos de propagação total na primeira e segunda regiões. 
3. As matrizes de multiplicadores externos à esquerda e à direita da primeira e segunda regiões, $D_{11}^{L}, D_{11}^{R}, D_{22}^{L}$ e $D_{22}^{R}$, foram introduzidas por Miyazawa (1966). Os multiplicadores dessas matrizes são incorporados na decomposição multiplicativa das inversas de Schur e representam os efeitos de propagação total na primeira e segunda regiões, tanto quanto os produtos internos e externos da matriz regional de multiplicadores

4 e 5. A introdução das inversas de Schur abreviadas, $D_{11}, D_{22}$, e os multiplicadores internos induzidos à esquerda e à direita para a primeira e segunda regiões, $B_{1}^{L}, B_{1}^{R}, B_{2}^{L}$ e $B_{2}^{R}$, permitem obter a decomposição multiplicativa das inversas de Schur:

$$
D_{1}=B_{1}^{L} D_{11}=D_{11} B_{1}^{R} ; \quad D_{2}=B_{2}^{L} D_{22}=D_{22} B_{2}^{R}
$$

e suas correspondentes representações aditivas.

6 a 10. A fórmula para este grupo de multiplicadores pode ser obtida por meio dos blocos de matrizes:

$$
M=\left[\begin{array}{cc}
A_{11} & A_{12} \\
A_{21} & 0
\end{array}\right], \quad N=\left[\begin{array}{cc}
0 & A_{12} \\
A_{21} & A_{22}
\end{array}\right], \quad S=\left[\begin{array}{cc}
0 & A_{12} \\
A_{21} & 0
\end{array}\right]
$$

os quais representam as ligações para trás e para frente da primeira e segunda regiões, bem como as relações inter-regionais de a mbas regiões.

A matriz $D_{22}=\left(I-A_{21} B_{1} A_{12}\right)^{-1}$ é interpretada como o multiplicador de renda inter-regional, enquanto $D_{22} A_{21} B_{1}$ refere-se à matriz do multiplicador de formação de renda. Além disso, a seguinte inversa de Schur

$$
D_{1}^{*}=\left(I-A_{11}-A_{12} A_{21}\right)^{-1}
$$

pode ser referida como a inversa de Leontief ampliada e, as inversas

$$
D_{11}^{* L}=\left(I-B_{1} A_{12} A_{2 I}\right)^{-1} ; \quad D_{1 I}^{* R}=\left(I-A_{12} A_{21} B_{1}\right)^{-1}
$$

são chamadas de matrizes de multiplicadores da inversa acrescentada à esquerda e à direita, as quais refletem os efeitos de mudanças endógenas nos gastos de consumo de cada grupo de renda. 
Quadro 5.1. Multiplicadores regionais internos e sua propriedades.

1. Multiplicadores regionais internos:

$B_{1}=\left(I-A_{11}\right)^{-1} ; \quad B_{2}=\left(I-A_{22}\right)^{-1}$

2. Complementos e inversas de Schur:

$S_{1}=I-A_{11}-A_{12} B_{2} A_{21} ; \quad S_{2}=I-A_{22}-A_{21} B_{1} A_{12}$

$D_{1}=\left(I-A_{11}-A_{12} B_{2} A_{21}\right)^{-1} ; \quad D_{2}=\left(I-A_{22}-A_{21} B_{1} A_{12}\right)^{-1}$

3. Multiplicadores externos a esquerda e a direita de Miyazawa:
$D_{11}^{L}=\left(I-B_{1} A_{12} B_{2} A_{21}\right)^{-1}$;
$D_{22}^{L}=\left(I-B_{2} A_{21} B_{1} A_{12}\right)^{-1}$
$D_{11}^{R}=\left(I-A_{12} B_{2} A_{21} B_{1}\right)^{-1}$;
$D_{22}^{R}=\left(I-A_{21} B_{1} A_{12} B_{2}\right)^{-1}$

Principais Propriedades:

$D_{1}=B_{1} D_{11}^{R}=D_{11}^{L} B_{1} ; \quad D_{2}=B_{2} D_{22}^{R}=D_{22}^{L} B_{2}$

4. Inversas de Schur abreviadas:

$D_{11}=\left(I-A_{12} B_{2} A_{21}\right)^{-1} ; \quad D_{22}=\left(I-A_{21} B_{1} A_{12}\right)^{-1}$

5. Multiplicadores internos induzidos a esquerda e a direita:

$B_{1}^{L}=\left(I-D_{11} A_{11}\right)^{-1} ; \quad B_{2}^{L}=\left(I-D_{22} A_{22}\right)^{-1}$

$B_{I}^{R}=\left(I-A_{11} D_{11}\right)^{-1} ; \quad B_{2}^{R}=\left(I-A_{22} D_{22}\right)^{-1}$

Principais Propriedades:

$D_{1}=B_{1}^{L} D_{11}=D_{11} B_{1}^{R} ; \quad D_{2}=B_{2}^{L} D_{22}=D_{22} B_{2}^{R}$

6. Inversas de Leontief ampliadas:

$D_{1}^{*}=\left(I-A_{11}-A_{12} A_{21}\right)^{-1} ; \quad D_{2}^{*}=\left(I-A_{22}-A_{21} A_{12}\right)^{-1}$

7. Multiplicadores externos induzidos:

$D_{11}^{*}=\left(I-A_{12} A_{21}\right)^{-1} ; \quad D_{22}^{*}=\left(I-A_{21} A_{12}\right)^{-1}$

8. Multiplicadores internos induzidos à esquerda e à direita:

$\begin{array}{ll}B_{1}^{*}=\left(I-D_{11}^{*} A_{11}\right)^{-1} ; & B_{2}^{*}=\left(I-D_{22}^{*} A_{22}\right)^{-1} \\ B_{1}^{* R}=\left(I-A_{11} D_{11}^{*}\right)^{-1} ; & B_{2}^{* R}=\left(I-A_{22} D_{22}^{*}\right)^{-1}\end{array}$

Principais Propriedades:

$D_{1}^{*}=B_{1}^{*} D_{11}^{*}=D_{11}^{*} B_{1}^{* R} ; \quad D_{2}^{*}=B_{2}^{* \mathrm{~L}} D_{22}^{*}=D_{22}^{*} B_{2}^{* R}$

9. Inversas acrescentadas à esquerda e à direita:

$D_{11}^{* L}=\left(I-B_{1} A_{12} A_{21}\right)^{-1} ; \quad D_{22}^{* L}=\left(I-B_{2} A_{21} A_{12}\right)^{-1}$

$D_{11}^{* R}=\left(I-A_{12} A_{21} B_{1}\right)^{-1} ; \quad D_{22}^{* R}=\left(I-A_{21} A_{12} B_{2}\right)^{-1}$

Principais Propriedades:

$D_{1}^{*}=B_{1} D_{11}^{* R}=D_{11}^{* L} B_{1} ; \quad D_{2}^{*}=B_{2} D_{22}^{* R}=D_{22}^{* 2} B_{2}$ 
Quadro 5.1 Multiplicadores regionais internos e sua propriedades.

\section{Inversas acrescentadas induzidas a esquerda e a direita:}

$\begin{array}{ll}D_{11}^{*+L}=\left[I-D_{11}\left(A_{11}-A_{12} B_{2} A_{22} A_{21}\right)\right]^{-1} ; & D_{22}^{* L L}=\left[I-D_{22}\left(A_{22}-A_{21} B_{1} A_{11} A_{12}\right)\right]^{-1} ; \\ D_{11}^{* * R}=\left[I-\left(A_{11}-A_{12} B_{2} A_{22} A_{21}\right) D_{11}\right]^{-1} ; & D_{22}^{* w_{R}}=\left[I-\left(A_{22}-A_{21} B_{1} A_{11} A_{12}\right) D_{22}\right]^{-1}\end{array}$

Principais Propriedades:

$D_{1}^{*}=D_{11}^{* * L} D_{11}=D_{11} D_{11}^{* * R} ; \quad D_{2}^{*}=D_{22}^{* * L} D_{22}=D_{22} D_{22}^{* * R}$

5.4.2 Bloco de matrizes inversas de Leontief e classificação do bloco de matrizes dos multiplicadores externos à esquerda e à direita

Considere-se a hierarquia dos subsistemas de insumo-produto representada pela decomposição de $A=A_{1}+A_{2}$. Introduzindo os blocos inversos de Leontief, $L(A)=L=(I-A)^{-1}$ e $L\left(A_{l}\right)=L_{l}=\left(I-A_{l}\right)^{-1}$, este último, correspondente ao primeiro subsistema, os multiplicadores do bloco de matriz à esquerda e à direita, $M_{L}$ e $M_{R}$, são definidos pelas igualdades:

$$
L=L_{1} M_{R}=M_{L} L_{1}
$$

A definição de (5.32) implica que:

$$
\begin{aligned}
& M_{L}=L\left(I-A_{1}\right)=\left(I-L_{1} A_{2}\right)^{-1} \\
& M_{R}=\left(I-A_{1}\right) L=\left(I-A_{2} L_{1}\right)^{-1}
\end{aligned}
$$

$\mathrm{O}$ cálculo do bloco de multiplicadores externos, $M_{L}$ e $M_{R}$, é baseado na forma particular do bloco inverso de Leontief $L(A)=L$. Assim, aplicando o bloco inverso de Leontief, tem-se:

$$
L=\left[\begin{array}{cc}
D_{1} & D_{1} A_{12} B_{2} \\
D_{2} A_{21} B_{1} & D_{2}
\end{array}\right]
$$

Esta fórmula pode ser verificada pela multiplicação direta de matriz, usando as definições das inversas de Schur e suas propriedades (Quadro 5.1, elementos 1 e 2). Além disso, a aplicação das formulas (5.33), (5.34) e (5.35) permitem derivar a ordenação das interações sinergéticas entre regiões. Os resultados são apresentados no primeiro e no segundo nível da Quadro 5.2. 
Quadro 5.2 . Ordenação das interações sinergéticas entre os subsistemas econômicos.

(Continua)

Nível $1 \quad$ Descrição

Forma da matriz $A_{1}$

Nível $2 L=L_{1}+\left(M_{L}-I\right) L_{1}=L_{1}+L_{l}\left(M_{R}-I\right)$

I. Hierarquia da região isolada versus o resto da economia

$$
A_{1}=\left[\begin{array}{cc}
A_{11} & 0 \\
0 & 0
\end{array}\right]
$$

$L=\left[\begin{array}{cc}B_{1} & 0 \\ 0 & I\end{array}\right]+\left[\begin{array}{cc}B_{1} A_{12} & 0 \\ 0 & I\end{array}\right] D_{2}\left[\begin{array}{cc}I & I \\ I & I-S_{2}\end{array}\right]\left[\begin{array}{cc}A_{21} B_{1} & 0 \\ 0 & I\end{array}\right]$

II. $A$ ordem da hierarquia substituida das ligações inter-regionais da segunda região versus o subsistema triangular inferior

$$
A_{1}=\left[\begin{array}{cc}
0 & A_{12} \\
0 & 0
\end{array}\right]
$$

$L=\left[\begin{array}{cc}I & A_{12} \\ 0 & I\end{array}\right]+\left[\begin{array}{cc}D_{1} & 0 \\ 0 & D_{2}\end{array}\right]\left[\begin{array}{cc}I-S_{1} & A_{12} B_{2}-S_{1} A_{12} \\ A_{21} B_{1} & I-S_{2}\end{array}\right]$

III. A ordem da hierarquia substituida das ligações inter-regionais da primeira região versus o subsistema triangular superior.

$$
A_{1}=\left[\begin{array}{cc}
0 & 0 \\
A_{21} & 0
\end{array}\right]
$$

$L=\left[\begin{array}{cc}I & 0 \\ A_{21} & I\end{array}\right]+\left[\begin{array}{cc}D_{1} & 0 \\ 0 & D_{2}\end{array}\right]\left[\begin{array}{cc}I-S_{1} & A_{12} B_{2} \\ A_{21} B_{1}-S_{2} A_{21} & I-S_{2}\end{array}\right]$

IV. $A$ ordem da hierarquia substituida das ligações para trás e para frente da primeira região versus o resto da economia

$$
A_{1}=\left[\begin{array}{cc}
0 & 0 \\
0 & A_{22}
\end{array}\right]
$$

$L=\left[\begin{array}{cc}I & 0 \\ 0 & B_{2}\end{array}\right]+\left[\begin{array}{cc}I & 0 \\ 0 & B_{2} A_{21}\end{array}\right] D_{1}\left[\begin{array}{cc}I-S_{1} & I \\ I & I\end{array}\right]\left[\begin{array}{cc}I & 0 \\ 0 & A_{12} B_{2}\end{array}\right]$

V. Hierarquia das ligações para frente da primeira e da segunda regiões

$$
A_{1}=\left[\begin{array}{cc}
A_{11} & A_{12} \\
0 & 0
\end{array}\right]
$$

$L=\left[\begin{array}{cc}B_{1} & B_{1} A_{12} \\ 0 & I\end{array}\right]+\left[\begin{array}{c}B_{1} A_{12} \\ I\end{array}\right] D_{2}\left[\begin{array}{ll}A_{21} B_{1} & I-S_{2}\end{array}\right]$

VI. Hierarquias das ligações para trás da primeira e segunda regiões

$$
A_{1}=\left[\begin{array}{ll}
A_{11} & 0 \\
A_{21} & 0
\end{array}\right]
$$

$L=\left[\begin{array}{cc}B_{1} & 0 \\ A_{21} B_{1} & I\end{array}\right]+\left[\begin{array}{c}B_{1} A_{12} \\ I-S_{2}\end{array}\right] D_{2}\left[\begin{array}{ll}A_{21} B_{1} & I\end{array}\right]$

VII. $A$ hierarquia das relações intra versus inter-regionais

$$
A_{1}=\left[\begin{array}{cc}
A_{11} & 0 \\
0 & A_{22}
\end{array}\right]
$$

$L=\left[\begin{array}{cc}B_{1} & 0 \\ 0 & B_{2}\end{array}\right]+\left[\begin{array}{cc}D_{1} A_{12} B_{2} & 0 \\ 0 & D_{2} A_{21} B_{1}\end{array}\right]\left[\begin{array}{cc}A_{21} & I-A_{22} \\ I-A_{11} & A_{12}\end{array}\right]\left[\begin{array}{cc}B_{1} & 0 \\ 0 & B_{2}\end{array}\right]$ 
Quadro 5.2 - Ordenação das interações sinergéticas entre os subsistemas econômicos.

VII. A hierarquia das relações inter versus intra-regionais
$L=\left[\begin{array}{cc}D_{11}^{*} & D_{11}^{*} A_{12} \\ D_{22}^{*} A_{21} & D_{22}^{*}\end{array}\right]+\left[\begin{array}{cc}I & B_{1} A_{12} \\ B_{2} A_{21} & I\end{array}\right]\left[\begin{array}{cc}0 & A_{12} \\ A_{21} & 0\end{array}\right]$
0

IX. Ordem de hierarquia substituida de ligações para trás

$$
A_{1}=\left[\begin{array}{ll}
0 & A_{12} \\
0 & A_{22}
\end{array}\right]
$$

$L=\left[\begin{array}{cc}I & A_{12} B_{2} \\ 0 & B_{2}\end{array}\right]+\left[\begin{array}{c}1-S_{1} \\ B_{2} A_{21}\end{array}\right] D_{1}\left[\begin{array}{ll}I & A_{12} B_{2}\end{array}\right]$

X. Ordem de hierarquia substituída de ligações para frente $\quad A_{1}=\left[\begin{array}{cc}0 & 0 \\ A_{21} & A_{22}\end{array}\right]$

$L=\left[\begin{array}{cc}I & 0 \\ B_{2} A_{21} & B_{2}\end{array}\right]+\left[\begin{array}{c}1 \\ B_{2} A_{21}\end{array}\right] D_{1}\left[\begin{array}{ll}I-S_{1} & A_{12} B_{2}\end{array}\right]$

XI. A hierarquia das ligações para trás e para frente da primeira região versus o resto da economia

$$
A_{1}=\left[\begin{array}{cc}
A_{11} & A_{12} \\
A_{21} & 0
\end{array}\right]
$$

$L=\left[\begin{array}{cc}D_{1}^{*} & D_{1}^{*} A_{12} \\ A_{21} D_{1}^{*} & D_{22}\end{array}\right]+\left[\begin{array}{c}B_{1} A_{12} \\ I\end{array}\right] D_{2} D_{22} A_{22}\left[A_{21} B_{1} \quad I\right]$

XII. $A$ hierarquia do subsistema triangular superior versus as ligações inter-regionais da primeira região

$$
A_{1}=\left[\begin{array}{cc}
A_{11} & A_{12} \\
0 & A_{22}
\end{array}\right]
$$

$L=\left[\begin{array}{cc}B_{1} & B_{1} A_{12} B_{2} \\ 0 & B_{2}\end{array}\right]+\left[\begin{array}{c}B_{1} A_{12} \\ I\end{array}\right] D_{2} A_{21} B_{1}\left[\begin{array}{ll}I & A_{12} B_{2}\end{array}\right]$

XIII. A hierarquia do subsistema triangular inferior versus ligações inter-regionais da segunda região

$$
A_{1}=\left[\begin{array}{cc}
A_{11} & 0 \\
A_{21} & A_{22}
\end{array}\right]
$$

$L=\left[\begin{array}{cc}B_{1} & 0 \\ B_{2} A_{21} B_{1} & B_{2}\end{array}\right]+\left[\begin{array}{c}1 \\ B_{2} A_{2 l}\end{array}\right] D_{1} A_{12} B_{2}\left[\begin{array}{ll}A_{21} B_{1} & I\end{array}\right]$

XIV. Hierarquia do resto da economia versus a segunda região isolada

$$
A_{1}=\left[\begin{array}{cc}
0 & A_{12} \\
A_{21} & A_{22}
\end{array}\right]
$$

$L=\left[\begin{array}{cc}D_{11} & A_{12} D_{2}^{*} \\ D_{2}^{*} A_{21} & D_{2}^{*}\end{array}\right]+\left[\begin{array}{c}1 \\ B_{2} A_{21}\end{array}\right] D_{11} A_{11} D_{1}\left[\begin{array}{lll}I & A_{12} B & 2\end{array}\right]$

- Cada entrada no quadro consiste de dois níveis: o primeiro descreve a estrutura e mostra a correspondente forma da matriz $A$, enquanto o segundo mostra as decomposições aditivas da matriz bloco de Leontief. 


\subsubsection{Decomposição hierárquica aditiva dos blocos inversos de Leontief}

Considere-se a hierarquia do subsistema de insumo-produto representado pela decomposição $A=A_{1}+A_{2}$, em que a inversa de Leontief é dada por $L(A)=L=(I-A)^{-1}$ e a inversa de Leontief, relativa ao primeiro subsistema, é representado pela expressão $L\left(A_{1}\right)=L_{1}=\left(I-A_{1}\right)^{-1}$. A decomposição multiplicativa da inversa de Leontief $L=L_{I} M_{R}=M_{L} L_{1}$ pode ser convertida na soma:

$$
L=L_{l}+\left(M_{L}-I\right) L_{l}=L_{l}+L_{l}\left(M_{R}-I\right)
$$

Denotando $f$ o vetor de demanda final e $y$ o de produto total, pode-se decompor (5.36), dividindo o produto total em duas partes: $y_{1}=L_{l} f$ e o incremento $D y=y-y_{l}$. Essa decomposição é importante para analisar empiricamente a estrutura do produto total. No segundo nível da Quadro 5.2, são apresentadas as classificações das possíveis decomposições aditivas do bloco inverso de Leontief num sistema de insumoproduto dentro dos pares de combinações hierárquicas.

Embora 14 tipos de pares de combinações hierárquicas de ligações econômicas tenham sido apresentados (Quadro 5.2 e Figura 5.1), Sonis et al. (1997), Guilhoto et al. (1998) e Guilhoto et al. (1999), salientam que é possível sugerir uma tipologia de categorias que podem ser empregadas. Assim, tem-se a seguinte caracterização:

1. tipo de ligação para trás (VI, IX): poder de dispersão;

2. tipo de ligação para frente $(\mathrm{V}, \mathrm{X})$ : sensibilidade de dispersão;

3. tipo de ligações intra e inter-regionais (VII, VIII): dispersão interna e externa;

4. estilo de interações de região isolada versus o resto da economia (I, XIV, IV, XI) e

5. estilo de subsistema triangular versus as interações inter-regionais (II, XIII, III, XII).

A visão do sistema de hierarquias de ligações permitirá fornecer novas interpretações das propriedades das estruturas que são reveladas. Além disso, os sistemas de insumo-produto partilhados podem diferenciar-se entre os vários tipos de dispersão (como 1, 2 e 3) e entre os vários modelos de interações inter-regionais (como 
4 e 5). Essencialmente, as 5 categorias e os 14 tipos de pares de combinações hierárquicas de ligações econômicas propiciam a oportunidade de escolher de acordo com as qualidades especiais das atividades de cada região e com o tipo de problema que se apresenta, evidenciando que as opções existem para as bases de uma tipologia dos tipos de economia baseados na estrutura hierárquica. $\mathrm{O}$ uso das diferentes interações sinergéticas possibilita analisar e mensurar como ocorrem as transações entre regiões. Assim, é possível verificar o quanto as relações de produção em uma dada região afetam a produção de outra região.
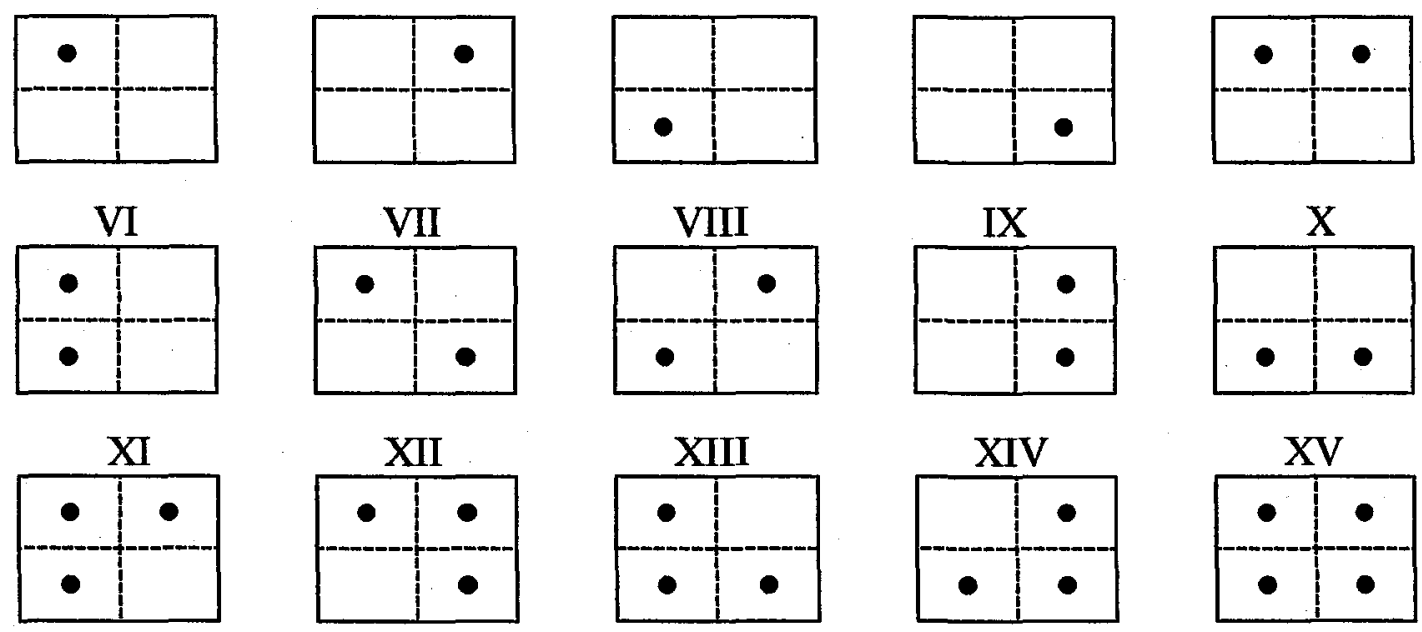

Figura 5.1 - Representação esquemática das formas possíveis da matriz $A_{1}$ - o caso de 2 regiões.

\subsubsection{O caso de $n$ regiões}

$\mathrm{O}$ número de decomposições aumenta significativamente na medida em aumenta as regiões. Assim, tem-se: a) 15 decomposições para o caso de duas regiões; incluindo o sistema como um todo; b) 511 para o caso 3 regiões; c) 65.535 para o caso de 4 regiões; c) 33.554 .431 para o caso de 5 regiões e assim sucessivamente. Em termos práticos, as combinações 1, 2, 3 e 4 das matrizes geram mais de 99,90\% de explicação da produção para uma dada região, o que permite tomar as explicações remanecentes como um resíduo para todas as outras combinações (Guilhoto, 1999). 
A representação em termos de equações para o sistema com $\boldsymbol{n}$ regiões tornase muito complexa. Por isso, para o presente estudo será apresentada uma idéia geral de como o sistema trabalha, em que se pode ver uma forma esquemática para o caso de 4 regiões representada na Figura 5.2.

A Figura 5.2 mostra um sistema inter-regional com 4 regiões totalizando 16 blocos de matrizes. Primeiramente, considera-se cada matriz isoladamente até completar o sistema. O próximo passo considera os 16 blocos de matrizes combinadas 2 a 2,3 a 3 e 4 a 4 até obter o sistema como um todo. Para mensurar a contribuição de cada combinação para a produção no processo produtivo é necessário subtrair do resultado da combinação de $k$ matrizes todas as possíveis combinações dessas matrizes de nível inferior, isto é, do resultado de um conjunto de 4 matrizes deve ser subtraído o resultado de todas as possíveis combinações dessas 4 matrizes ao nível de 3, 2 e 1 matrizes.

A aplicação desta metodologia para o caso de duas regiões foi feita por Guilhoto et al. (1998 e 1999) para a economia brasileira. Os dados usados são da matriz de insumo-produto do Brasil referente ao ano de 1992, sendo esta dividida em duas regiões: Nordeste e o resto da economia. A principal conclusão mostra que o Nordeste tem maior dependência sobre o resto da economia e, ao mesmo tempo, o resto da economia parece ser mais desenvolvido, além de apresentar uma estrutura produtiva mais complexa do que a do Nordeste.

Para o caso de 4 e 5 regiões Guilhoto (1999) empregou esta técnica para estudar as cinco grandes regiões da economia brasileira, usando um sistema interregional, construído para o ano de 1995. Constatou que, em geral, a região Norte não tem, praticamente, relações com a região Nordeste e vice-versa; enquanto a região Sul tem algum impacto sobre a produção da região Nordeste, esta não exerce nenhuma influência sobre aquela; a produção na região Centro-Oeste tem suas relações mais importantes com as regiões Sudeste e Sul e, as regiões Sul e Sudeste mostraram-se como as mais importantes no sistema. 


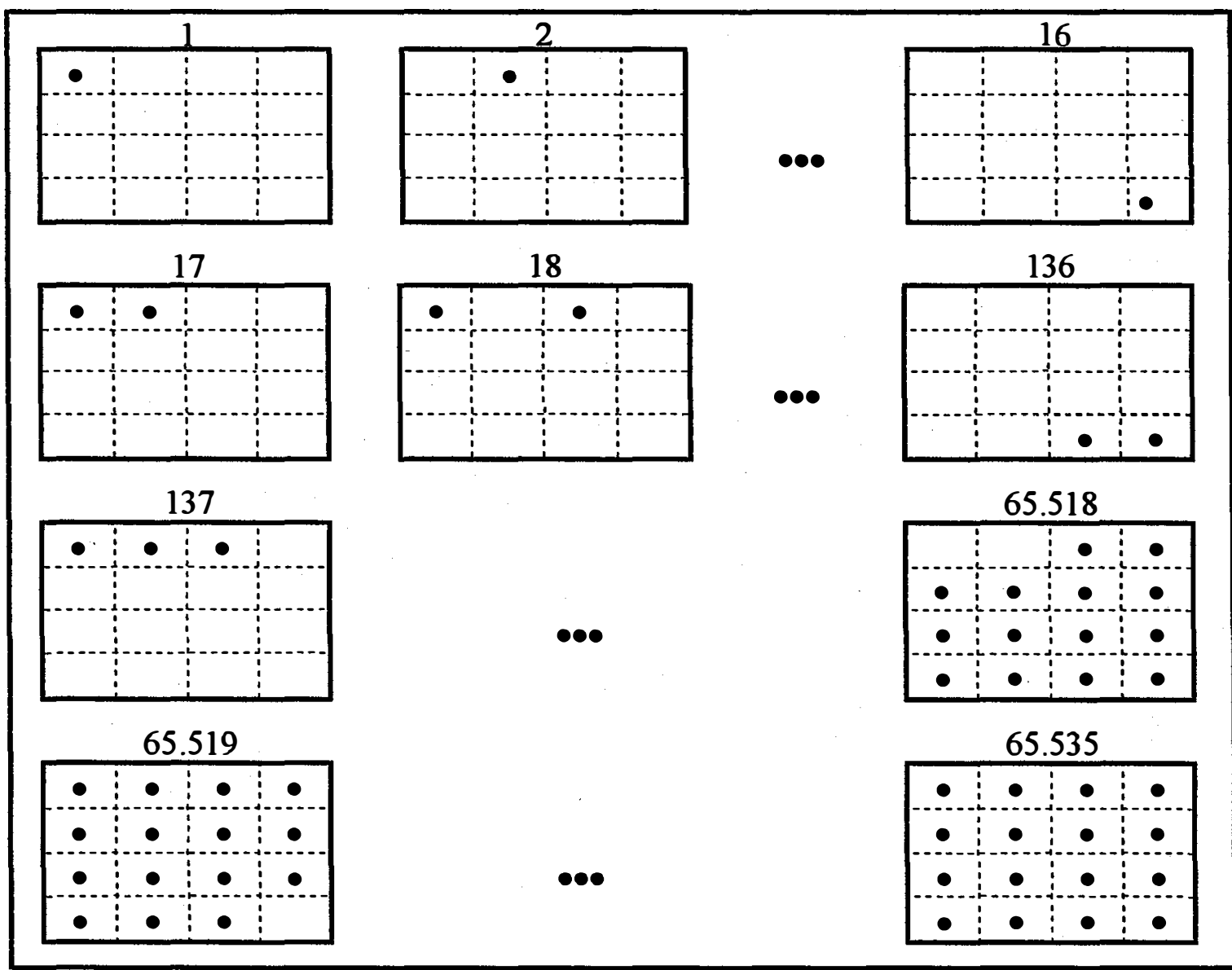

Figura 5.2 - Representação esquemática das formas possíveis da matriz $A_{1}$ - o caso de 4 regiões. 


\section{ANÁLISE DAS RELAÇÕES INTERSETORIAIS E INTER-REGIONAIS NA ECONOMIA PARANAENSE}

A teoria do insumo-produto permite identificar as relações intersetoriais de um sistema econômico, possibilitando, dessa forma, verificar os possíveis efeitos de políticas públicas e privadas sobre as estruturas de produção de uma dada região ou de um conjunto de regiões que constituem um sistema econômico. Torna-se necessário identificar as ligações intersetoriais mais relevantes para direcionar políticas de desenvolvimento econômico para a economia paranaense.

Nesse sentido, o objetivo básico que norteia o desenvolvimento deste capítulo centra-se na análise do sistema econômico inter-regional construído para a economia paranaense para o ano de 1995.

\subsection{Matriz de insumo-produto inter-regional ${ }^{17}$}

As transações entre as indústrias dos pólos regionais da estrutura econômica paranaense, em 1995, estão sintetizadas na Tabela 6.1. Nela, podem-se observar as demandas intermediárias por insumos e as demandas finais por produtos de um dado setor para cada pólo regional. Tais informações possibilitam, inicialmente, estabelecer alguns parâmetros sobre a dimensão econômica dos mercados, bem como caracterizar as situações mais prováveis do comportamento dos agentes neles envolvidos.

A dimensão econômica dos mercados traz, implicitamente, a idéia macroeconômica de que o tamanho do mercado possibilita o uso de tecnologias

\footnotetext{
${ }^{17}$ A matriz de insumo-produto inter-regional completa para a estrutura produtiva paranaense de 1995 pode ser vista no Anexo A.
} 
produtivas direcionadas para magnitudes cada vez maiores. Assim, as possibilidades de desenvolvimento da indústria, do comércio e da capacidade de negociação serão maiores ou menores dependendo da dimensão econômica de cada região (Montoyia, 1998).

$\mathrm{Na}$ Tabela 6.1, observou-se que a dimensão econômica dos pólos regionais de Curitiba e Londrina, medida pelo valor adicionado, representou 46,92\% e 23,20\%, respectivamente, enquanto os pólos regionais de Ponta Grossa e Cascavel, juntos, participaram com pouco menos de um terço desse indicador. Isso evidencia uma certa desigualdade do tamanho dos mercados da estrutura econômica paranaense. De fato, o pólo regional de Curitiba foi responsável por $47,37 \%$ da produção total do Paraná em 1995, seguido pelo pólo de Londrina com 22,97\%. Ambos geraram mais de dois terços da produção estadual.

As desigualdades na dimensão dos mercados refletem lacunas nas estruturas econômicas e nas escalas de produção de cada pólo regional. Pode-se verificar que o perfil da programação de investimentos privados e estaduais diretamente ligados à produção no Paraná, anunciados em 1995-96, indicou que a maior parte (70\%) das inversões foram canalizadas para o pólo regional de Curitiba, evidenciando que a utopia de crescimento espacial harmônico ignora as diferentes vocações e peculiaridades regionais (Lourenço, 1996b). Apesar disso, existe uma preocupação do governo estadual em promover o desenvolvimento regional, no sentido de desenvolver novos pólos e fortalecer aqueles já consolidados, por meio de uma estratégia política voltada ao aproveitamento pleno das potencialidades e das aptidões econômicas de cada região. Nesta direção, dois terços dos investimentos captados pelo Estado de São Paulo, nos últimos anos, foram direcionados para o interior. A distribuição desses investimentos só foi possível em virtude de um rede de ensino e de produção de tecnologia implantada em varias regiões do Estado, que começou a ser desenvolvida na década de 60 (Livoratti, 1998). 


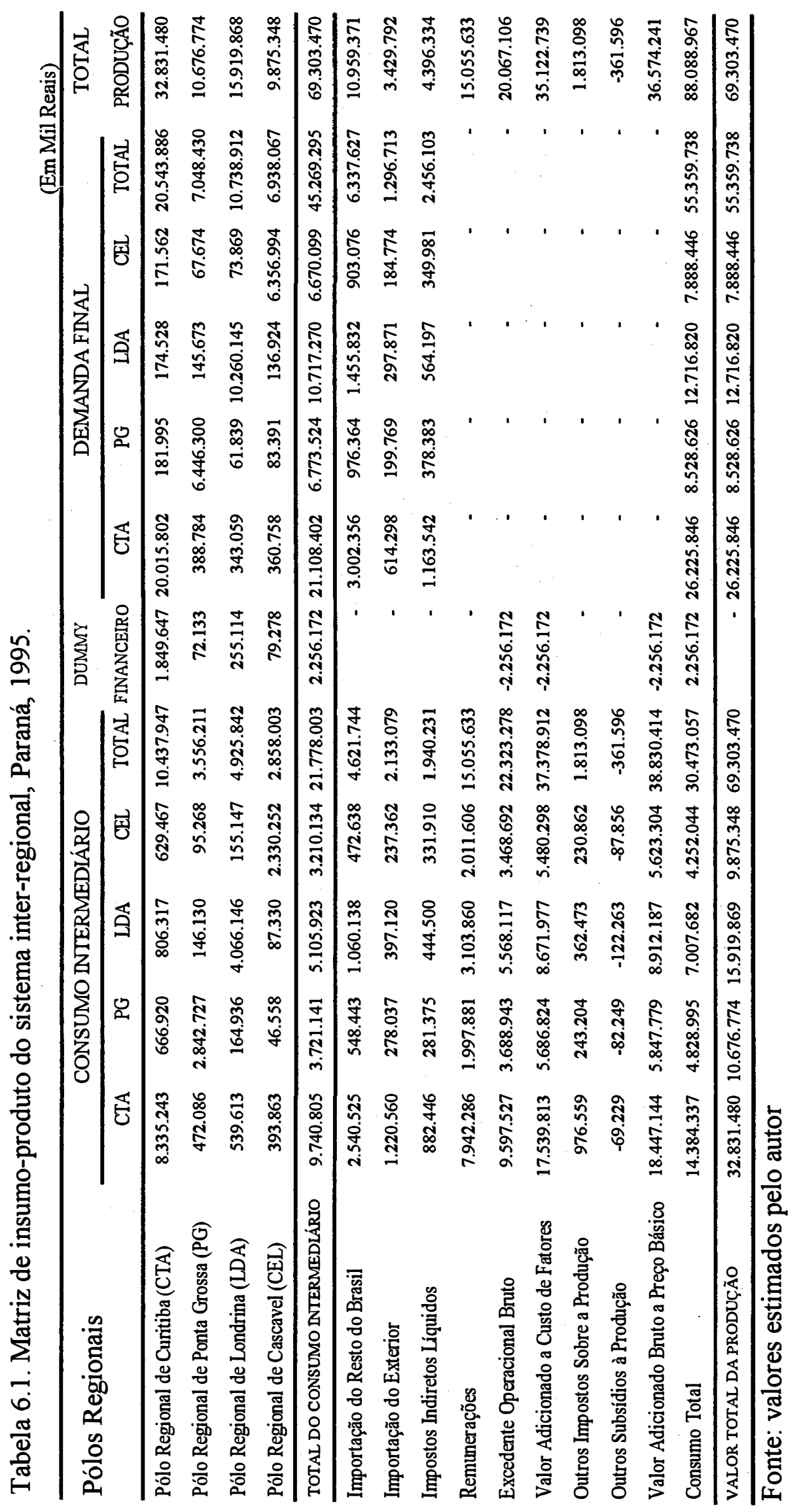




\subsection{Ligações industriais e setores-chave}

A interdependência das relações intersetoriais de uma economia baseia-se no fato de que os produtos não servem, somente, para o processo industrial, mas, também, para atender às necessidades dos setores de demanda final. Nesse aspecto, busca-se determinar os setores que apresentam o maior poder de encadeamento da economia, isto é, aqueles que mais a dinamizam.

A partir do modelo de Rasmussen (1956) e Hirschman (1958), descrito no capítulo 5, podem-se calcular os índices de ligações para trás e para frente. $\mathrm{O}$ primeiro indica quanto um setor demanda dos outros setores, enquanto o segundo informa o quanto um setor é demandado pelos outros. Valores maiores do que 1 indicam setores acima da média e, portanto, setores-chave para o crescimento da economia. Considerando uma definição mais restrita, McGilvray (1977) considera setores-chave na economia aqueles que apresentam, simultaneamente, índices de ligações para frente e para trás maiores que 1 .

Os setores-chave estão associados à idéia de estabelecer prioridade na alocação de recursos e na estratégia de promoções industriais. Espera-se que os recursos direcionados para estes setores estimulem o crescimento mais rápido da produção, do emprego e da interdependência econômica, diferentemente do que se fossem aplicados em setores não considerados chave na economia.

\subsection{1 Índices de ligações de Rasmussen-Hirschman ${ }^{18}$}

Os índices de ligações de Rasmussen-Hirschman para frente e para trás, para os 31 setores do sistema inter-regional e para o Paraná, são mostrados na Tabela 6.2. Antes de discutir os resultados contidos na Tabela 6.2 faz-se necessário um breve esclarecimento de sua organização. Verifica-se que existem um total de 124 índices para

\footnotetext{
${ }^{18}$ É importante esclarecer a similaridade dos índices de ligações para trás na Tabela 6.2. Isso deve-se à hipótese adotada para estimar os fluxos de insumos inter-regionais, isto é, considerou-se a mesma tecnologia para todas as regiões do sistema econômico paranaense.
} 
trás e para frente, indicando que o tamanho da matriz inversa do sistema inter-regional é da ordem $124 \times 124$ setores, isto é, 31 setores para cada pólo regional. Assim, poder-seia pensar que fossem listados 124 setores na respectiva coluna dos nomes dos setores. No entanto, é importante lembrar que, em cada pólo regional, as linhas e setores são comuns o que justifica listar simplesmente 31 setores, uma vez que esse tipo de organização dos dados permite visualizar as diferenças de comportamento dos pólos regionais na economia paranaense.

A Figura 6.1 sintetiza o padrão médio de comportamento dos índices para frente e para trás para os pólos regionais que compõem o sistema inter-regional. Em geral, as regiões de Curitiba e Londrina apresentaram mais setores com índices de ligações para frente e para trás maiores do que 1, indicando uma estrutura econômica mais integrada internamente quando comparada à das demais regiões do sistema. Por outro lado, a região de Cascavel exibiu padrões típicos de ligações fracas entre as indústrias domésticas, refletidas pelos baixos índices médios de ligações para trás (0.995) e para frente (0.874).

Esses resultados evidenciam dois padrões dentro do sistema inter-regional. $\mathrm{O}$ primeiro demonstra que as regiões-pólo de Curitiba e Londrina possuem uma estrutura industrial melhor articulada, enquanto o segundo denota que os pólos de Ponta Grossa e Cascavel ainda buscam a implementação e a consolidação das suas estruturas industriais.

Ao se considerar setores-chave na economia aqueles que apresentam tanto índices de ligações para trás quanto para frente com valores maiores do que 1 (McGilvray, 1977), os setores Celulose, Papel e Gráfica (9) e Indústria Têxtil (14), para o conjunto do Paraná; Fabricação de Minerais não Metálicos (3), Material de Transportes (7) e Celulose, Papel e Gráfica (9) para o pólo regional de Curitiba são considerados setores-chave na economia. Os pólos regionais de Ponta Grossa e Londrina apresentaram apenas um setor-chave em suas economias, Celulose, Papel e Gráfica (9) e Indústria Têxtil (14), respectivamente. Esses resultados sugerem que estes setores são os mais indicados para se implementarem políticas de desenvolvimento industrial, gerando, desta forma, um rápido crescimento da produção, renda e emprego na economia. Com 


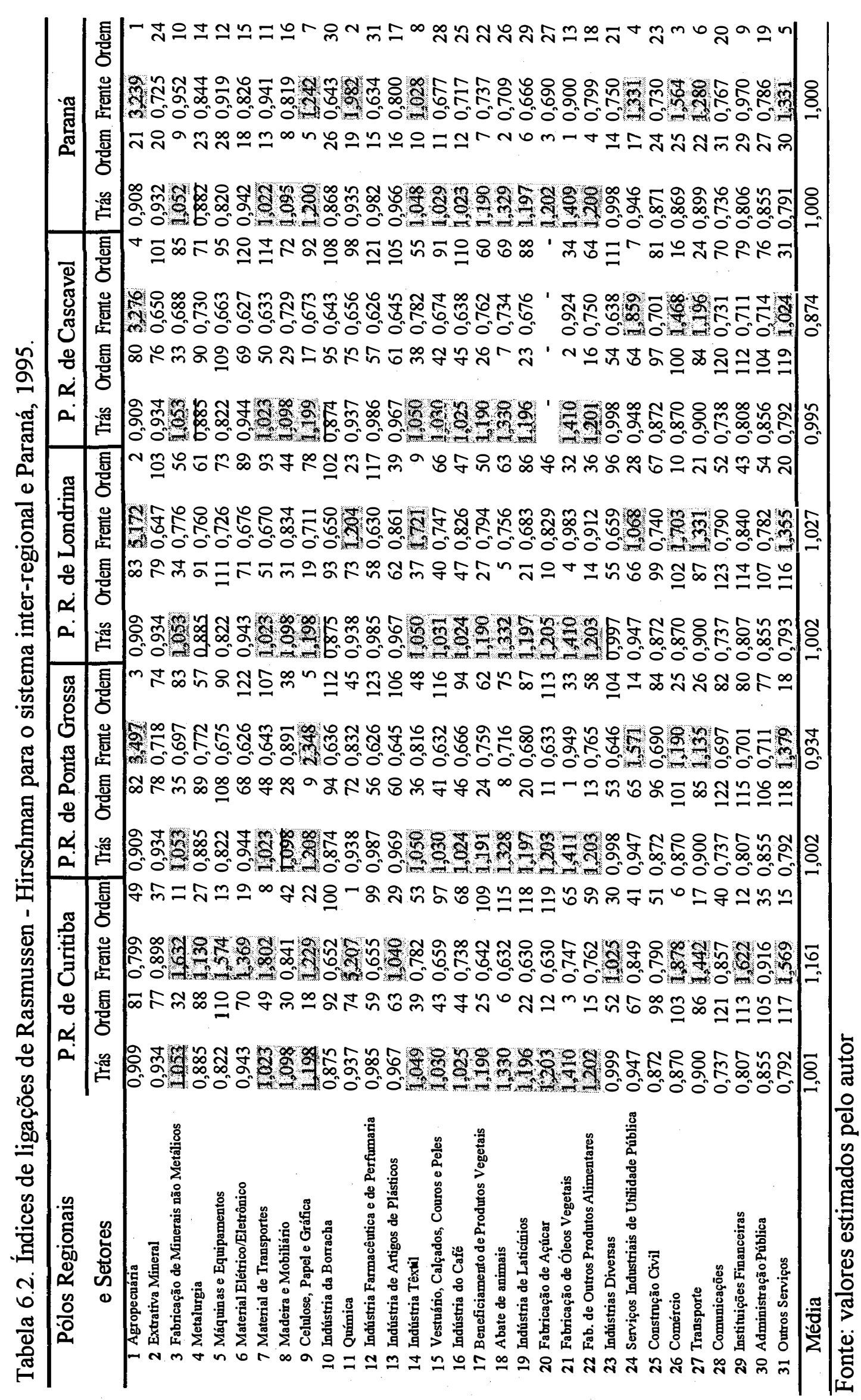


base neste critério, o pólo regional de Cascavel não apresentou setor-chave em seu sistema econômico.

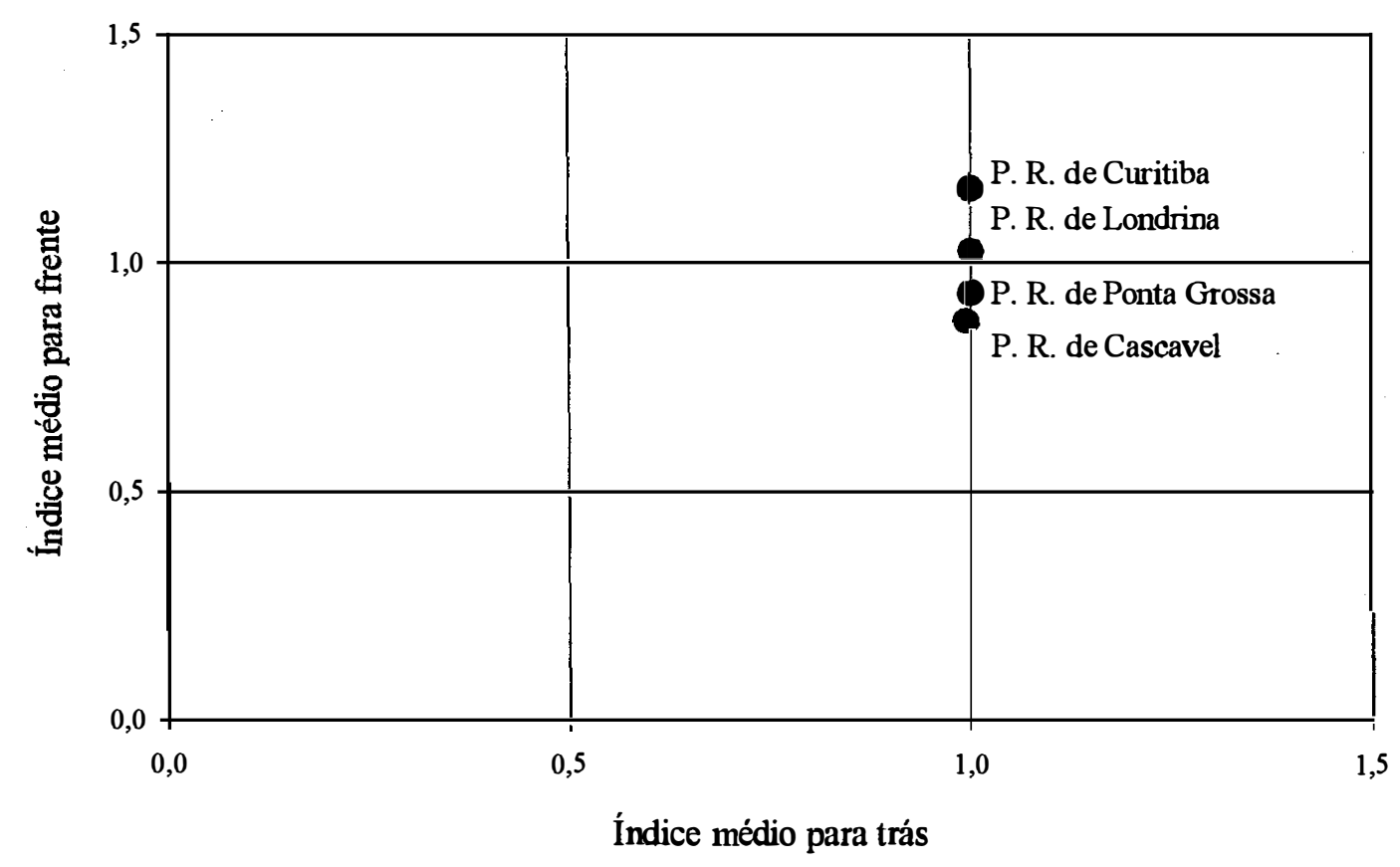

Figura 6.1 - Padrão médio dos Índices de ligações de Rasmussen-Hirschman para os pólos regionais, Paraná, 1995.

Na hipótese de "relaxamento" deste critério e seguindo Rasmussen (1956) e Hirschman (1958), para os quais setores-chave são aqueles que apresentam índices de ligações para frente ou para trás maiores do que 1 , tem-se um número maior de setoreschave em todas as regiões-pólo do sistema inter-regional e no Paraná. Assim, a estrutura agregada da economia paranaense apresentou 19 setores-chave, indicando uma economia diversificada e integrada, centrada, basicamente, na indústria de transformação, notadamente aquelas que integram a agroindústria alimentar, como * demandante de insumos.

Dos 13 setores com forte encadeamento para trás, na estrutura agregada da economia paranaense, destacaram-se os setores Fabricação de Óleos Vegetais (21), Abates de Animais (18), Fabricação de Açúcar (20), Fabricação de Outros Produtos Alimentares (22) e Celulose, Papel e Gráfica (9). Por outro lado, dentre os 8 setores com 
maior encadeamento para frente, no conjunto da economia paranaense, merecem destaque os setores Agropecuária (1), Química (11), Comércio (26), Serviços Industriais de Utilidade Pública (24) e Outros serviços (31). Os índices de ligações para trás e para frente, para o Paraná, estão ilustrados na Figura 6.2.

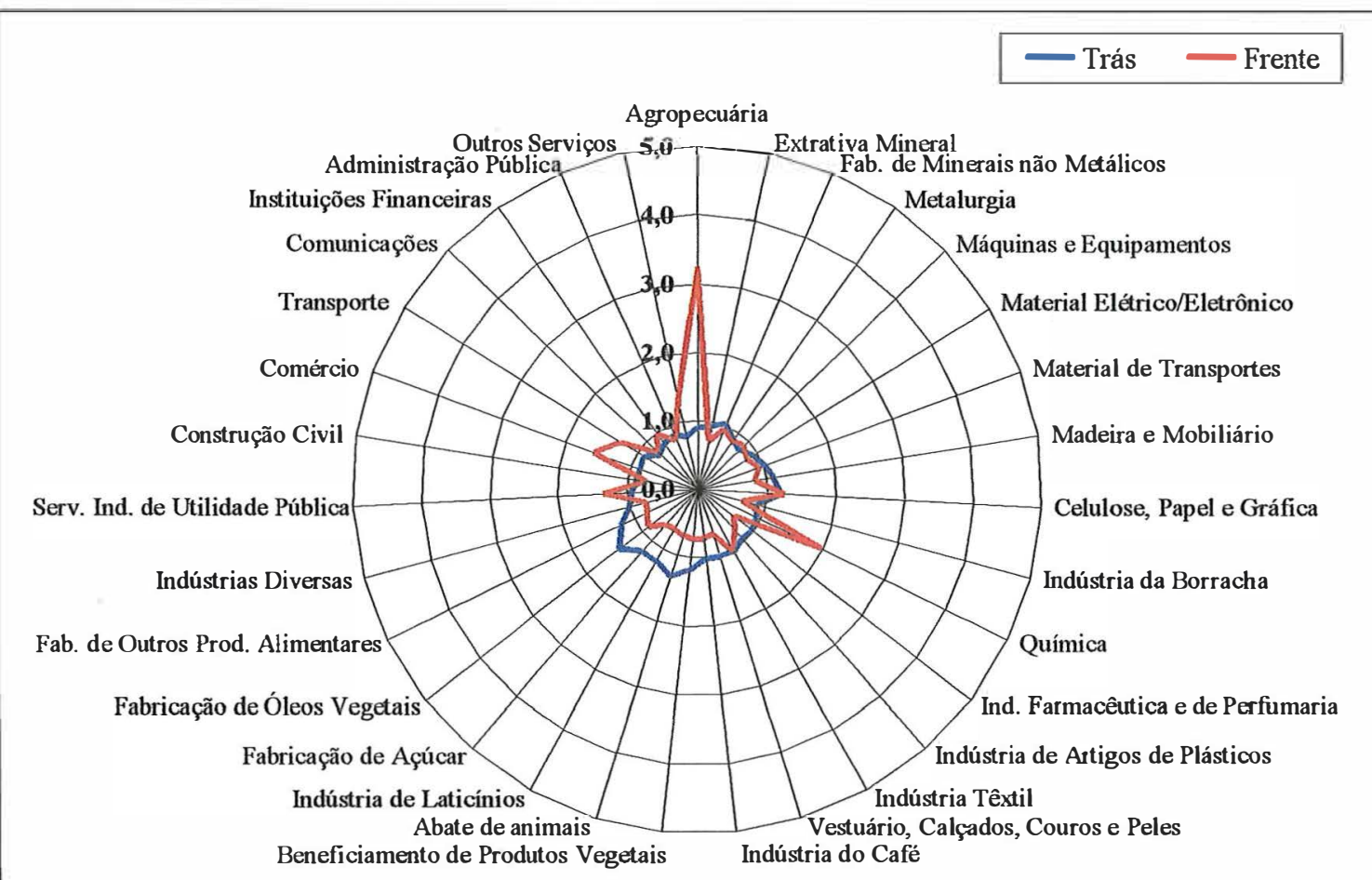

Figura 6.2 - Índices de ligações de Rasmussen-Hirschman, Paraná, 1995.

Os índices para trás e para frente para o pólo regional de Curitiba podem ser vistos na Tabela 6.2 e ilustrados na Figura 6.3. Observar-se, que esse pólo apresenta o maior número de setores-chave em relação aos demais e é importante notar que não tem sua base produtiva centrada no setor primário. No entanto, cabe destacar o

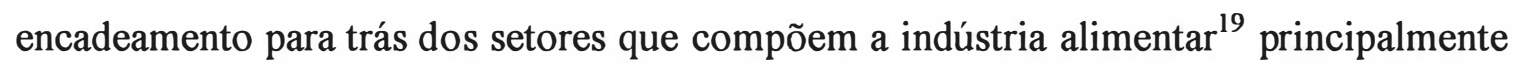
os de Fabricação de Óleos Vegetais (21), Abate de Animais (18), Fabricação de Açúcar (20) e Fabricação de Outros Produtos Alimentares (22), Percebe-se que esses setores são os mais indicados para se dirigir políticas de estímulo de demanda por insumos

19 Segundo Castro (1994), importantes empresas da indústria alimentar localizam-se na Região Metropolitana de Curitiba, porém essas atividades assumem um peso maior em outras regiões do Estado. 
intermediários, especificamente se esta demanda for atendida por insumos da própria região e, no contexto estadual, por insumos dos outros pólos componentes do sistema inter-regional, notadamente aqueles produtores de matéria prima oriundas do setor agropecuária.

Dentre os setores com maior encadeamento para frente na economia do pólo regional de Curitiba, merecem destaque os setores Química (11), Comércio (26), Material de Transportes (7), Fabricação de Minerais não Metálicos (3) e Instituições Financeiras (29). Dadas as características da economia deste pólo regional, pode-se concluir que se trata de uma estrutura econômica diversificada e integrada.

O pólo regional de Londrina, segundo maior produtor do Estado, exibiu 19 setores-chave, considerando-se o conceito menos restrito (Tabela 6.2 e Figura 6.4). Os setores que apresentaram os maiores índices para trás estavam vinculados diretamente à indústria alimentar, notadamente os de Fabricação de Óleos Vegetais (21), Abate de Animais (18), Fabricação de Açúcar (20) e Fabricação de Outros Produtos Alimentares (22). Por outro lado, os setores Agropecuária (1), Indústria Têxtil (14), Comércio (26) e Outros Serviços (31) apresentaram os índices de ligações para frente bastante superiores à média da região. Pode-se afirmar que o pólo de Londrina, a exemplo do de Curitiba, apresentou uma estrutura econômica diversificada e integrada.

Fazendo um parênteses, a agropecuária paranaense mostra-se dinâmica e diversificada, passando a moderna e tecnificada desde o final dos anos sessenta, e mais claramente nos anos setenta, quando altera profundamente sua base técnica e social, aproximando-a da agropecuária dos países industrializadas. É claro que sobre essa base agrícola implantou-se em todos os pólos regionais, com menos intensidade no de Curitiba, a agroindústria. Nesse contexto, o setor Agropecuário (1), enquanto fornecedor de matéria prima para a agroindústria e com fortes ligações para frente, merece especial atenção no sentido de implementação de políticas de crescimento econômico, não só para o pólo regional de Londrina, mas também, para todos os pólos regionais.

A estrutura da economia do pólo regional de Ponta Grossa assemelha-se à de Londrina, no que se refere aos índices de ligações para trás (Tabela 6.2 e Figura 6.5). 


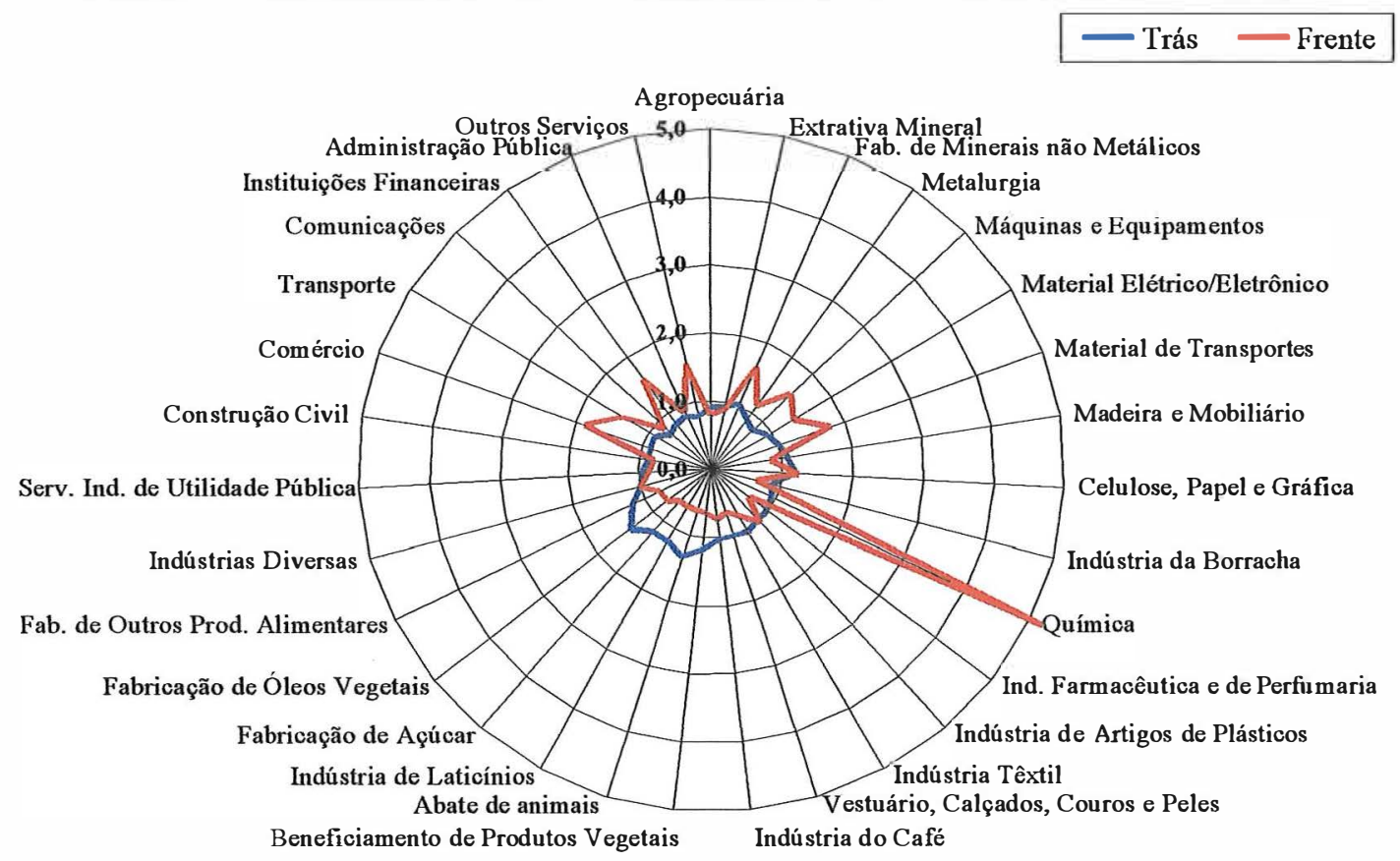

Figura 6.3 - Índices de ligações de Rasmussen-Hirschman, pólo regional de Curitiba, 1995.

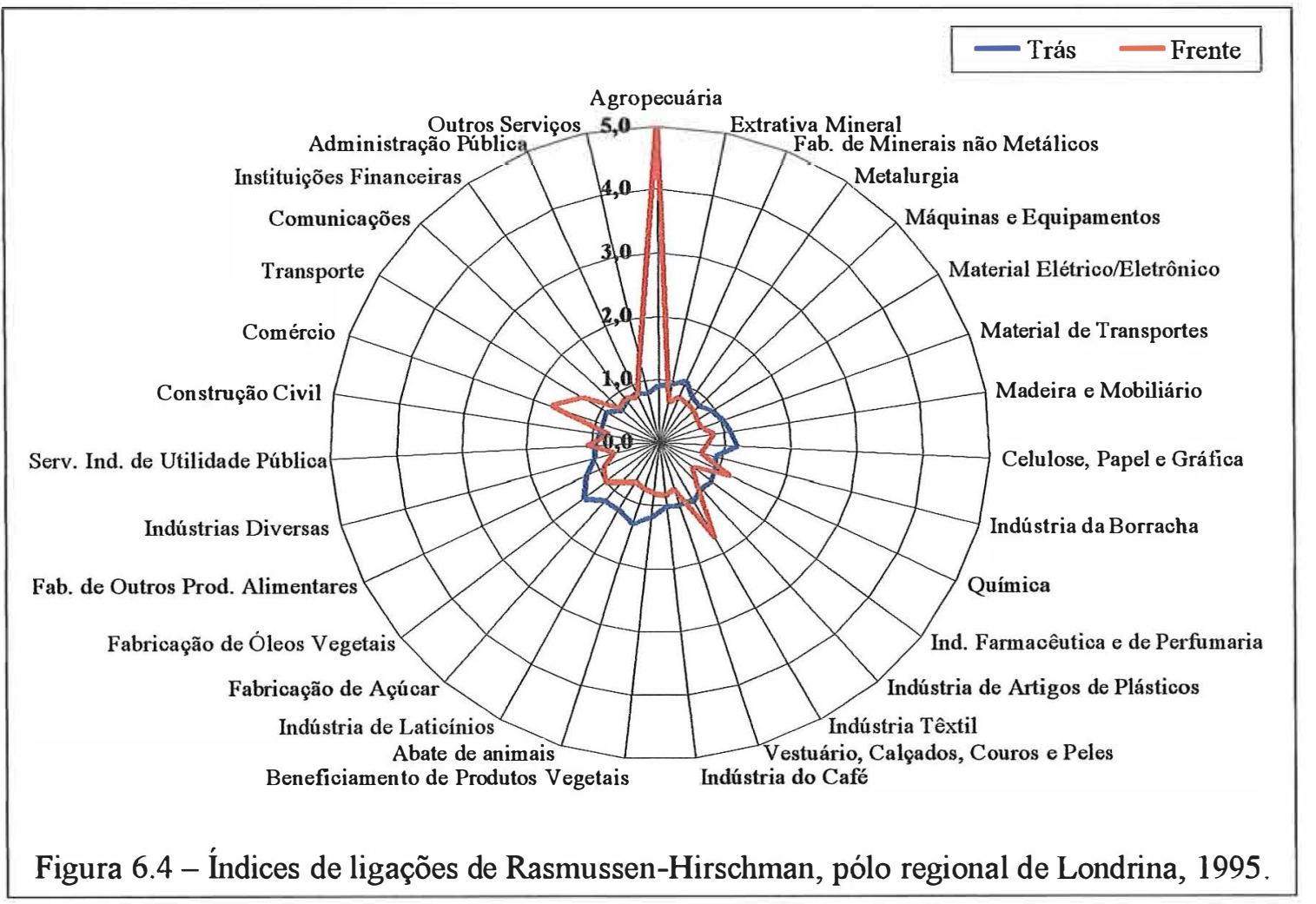


Constataram-se 18 setores-chave no sentido menos restrito, destacando-se os setores Agropecuária (1), Celulose, Papel e Gráfica (9), Serviços Industriais de Utilidade Pública (24) e Fabricação de Óleos Vegetais (21). Tradicionalmente, essa região-pólo caracteriza-se pelas atividades madeireiras e concentra as principais fábricas de papel e celulose do Estado do Paraná.

A exemplo das outras regiões-pólo, os setores ligados à indústria alimentar foram os que apresentaram os maiores índices de ligações para trás, merecendo destaque Fabricação de Óleos Vegetais (21) e Abate de Animais (18). Apesar de esse pólo regional não ser o principal produtor de grãos do estado, um terço da capacidade de esmagamento de oleaginosas localiza-se nele, especificamente na cidade de Ponta Grossa (Roesing e Santos, 1999). Portanto, esses setores devem ser priorizados para implementação de políticas de desenvolvimento industrial. Os setores Agropecuária (1), Celulose, Papel e Gráfica (9) e Serviços Industriais de Utilidade Pública (24) foram os que exibiram os maiores índices de ligações para frente.

Por último, o pólo regional de Cascavel não apresentou setor-chave no sentido restrito. A média dos índices de ligações para trás (0.995) apresentou-se ligeiramente superior à média dos índices de ligações para frente $(0.874)$, caracterizando uma estrutura econômica de padrão industrial de ligações fracas, evidenciada na Figura 6.1 .

Nesta região-pólo, os setores da indústria alimentar, a exemplo do ocorrido nas demais regiões, foram os que exibiram os maiores índices para trás, com destaque para os setores Fabricação de Óleos Vegetais (21), Abate de Animais (18), Fabricação de Outros Produtos Alimentares (22) e Indústria de Laticínios (19) (Tabela 6.2 e Figura 6.6). A exemplo dos outros pólos, exceto o de Curitiba, os setores que se destacaram, em termos de ligações para frente, foram Agropecuária (1) e Serviços Industriais de Utilidade Pública (24). Vale registrar que este pólo respondeu por $27,70 \%$ do valor bruto da produção animal e vegetal em 1995 (IBGE, 1998). Além disso, a importância do setor Serviços Industriais de Utilidade Pública (24) deve-se à localização da usina hidrelétrica de Itaipu. 

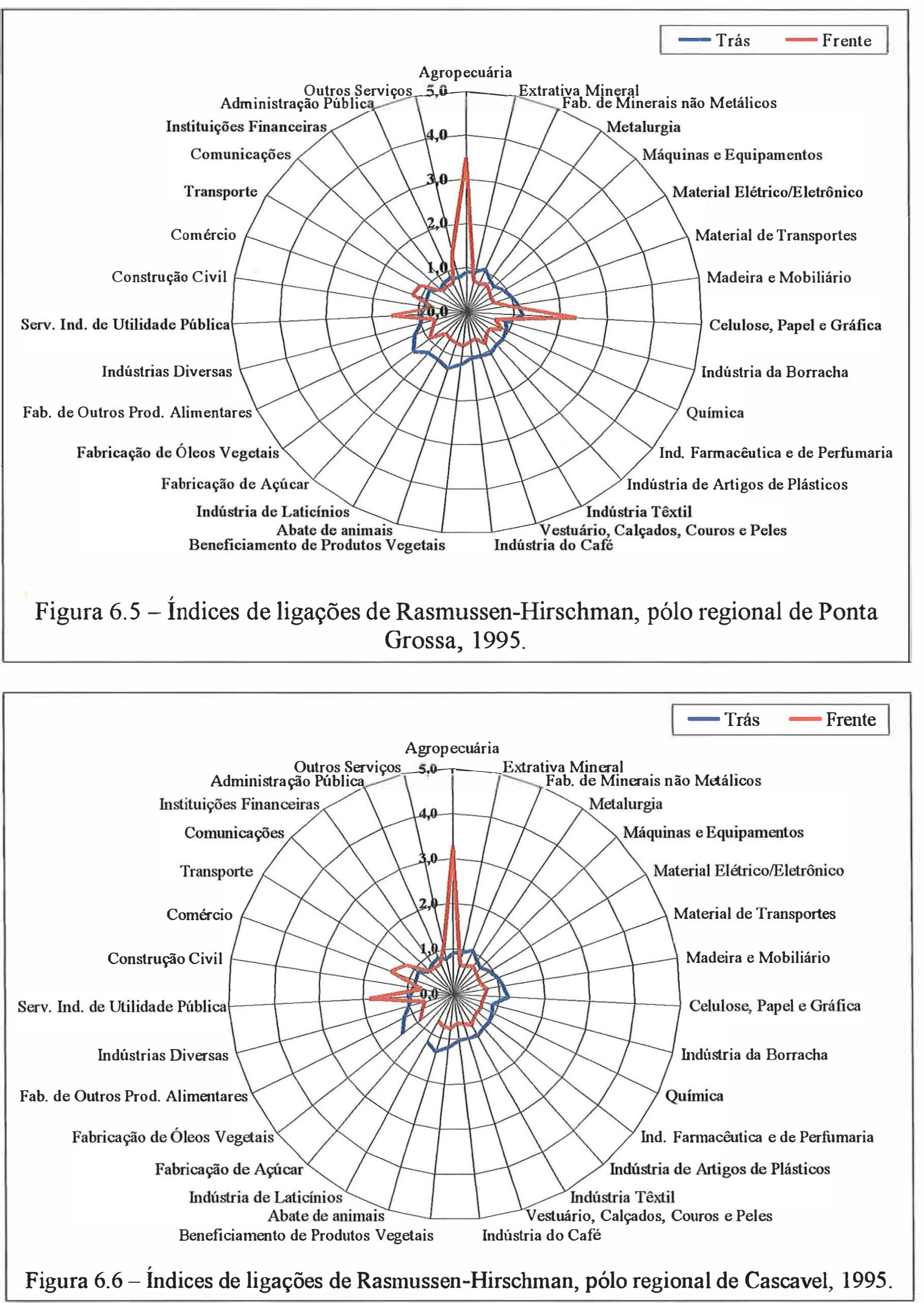
Em síntese, podem-se estabelecer, de acordo com os maiores índices de ligações, os setores com maior capacidade para dinamizar a economia do Estado do Paraná. Considerando-se os maiores índices de ligações para frente, observa-se que a oferta de insumos se processa por meio dos setores Agropecuária (1), Química (11) e Comércio (26) para o conjunto do Estado; Química (11), Comércio (26), Material de Transportes (7) e Fabricação de Minerais não Metálicos (3) para o pólo a regional de Curitiba; dos setores Agropecuária (1), Celulose, Papel e Gráfica (9) e Serviços Industriais de Utilidade Pública (24) para o pólo a regional de Ponta Grossa; dos setores Agropecuária (1), Indústria Têxtil (14) e Comércio (26) para o pólo regional de Londrina e dos setores Agropecuária (1), Serviços Industriais de Utilidade Pública (24) e Comércio (26) para o pólo regional de Cascavel. Conclui-se, portanto, que as relações intersetoriais para frente no sistema econômico do Paraná são dinamizadas, principalmente, pelos setores Química (11), Agropecuária (1), Celulose, Papel e Gráfica (9) e Comércio (26).

A demanda de insumos para o processamento industrial para todas as regiões do sistema, está concentrada, basicamente, nos setores que compõem a indústria alimentar, notadamente os setores Fabricação de Óleos Vegetais (21) e Abate de Animais (18).

Finalmente, é interessante observar que, para todas as regiões-pólo, os setores da indústria alimentar (setores 16 a 22), apresentaram índices de ligações para trás maiores do que 1, destacando-se o setor de Fabricação de Óleos Vegetais (21).

\subsubsection{Campo de influência, Paraná e o sistema inter-regional}

A metodologia de campo de influência, descrita na seção 5.1 .2 do capítulo 5 , foi aplicada para o Paraná e para o sistema inter-regional e os resultados são vistos nas Figuras 6.7 e 6.8. O conceito de campo de influência, desenvolvido por Sonis e Hewings (1989 e 1994), mostra como se distribuem as mudanças dos coeficiente diretos no sistema econômico como um todo, permitindo, dessa forma, determinar quais relações entre os setores seriam mais importantes dentro do processo produtivo. Guilhoto et al. 
(1994) salientam que a noção de campo de influência não está dissociada dos índices de ligações, sendo uma análise complementar a esta na medida em que os principais elos de ligações dentro da economia vão se encontrar nos setores que apresentam os maiores índices de ligações, tanto para frente como para trás.

Os resultados obtidos para o Paraná e para o sistema inter-regional possibilitam verificar quais dos setores causam maiores mudanças intra e inter-regionais no sistema econômico paranaense, quando se estabelecem pequenas mudanças nos coeficientes de produção.

Antes de iniciar a análise, é importante mencionar que foram escolhidos 60 coeficientes setoriais com maior campo de influência para a estrutura econômica do Paraná, plotados na Figura 6.7, cujos eixos discriminam os setores considerados nesta pesquisa. Para o sistema inter-regional foram selecionados os 250 maiores coeficientes, considerando os 31 setores para cada pólo regional.

Inicialmente, observando a Figura 6.7, constatou-se que os principais elos de ligações da economia do Estado foram dominadas pelos setores Celulose, Papel e Gráfica (9), Fabricação de Óleos Vegetais (21) e Serviços Industriais de Utilidade Pública (24). O setor Celulose, Papel e Gráfica (9), classificado como setor-chave no conceito restrito, apresentou 8 coeficientes relativos a vendas para outros setores e 7 envolvendo compras de seus produtos por outros setores.

O campo de influência confirmou os resultados encontrados pelos índices de Rasmussen-Hirschman para o setor Fabricação de Óleos Vegetais (21). Este setor apresentou 8 coeficientes de vendas para outros setores e 3 setores compradores de seus produtos. No ramo serviços, o setor Serviços Industriais de Utilidade Pública (24) mostrou-se fortemente relacionado com vários setores da economia paranaense, revelando 8 e 7 coeficientes relativos a venda e compra, respectivamente. A importância de setor Agropecuário (1) para a economia estadual parece evidente. A dinâmica deste setor ficou restrita às ligações para trás com 31 dos 60 coeficientes com maiores campos de influência, comprovando seu domínio como setor comprador de insumos dos demais setores da economia paranaense, considerando pequenas variações nos seus coeficientes. 
Setores compradores

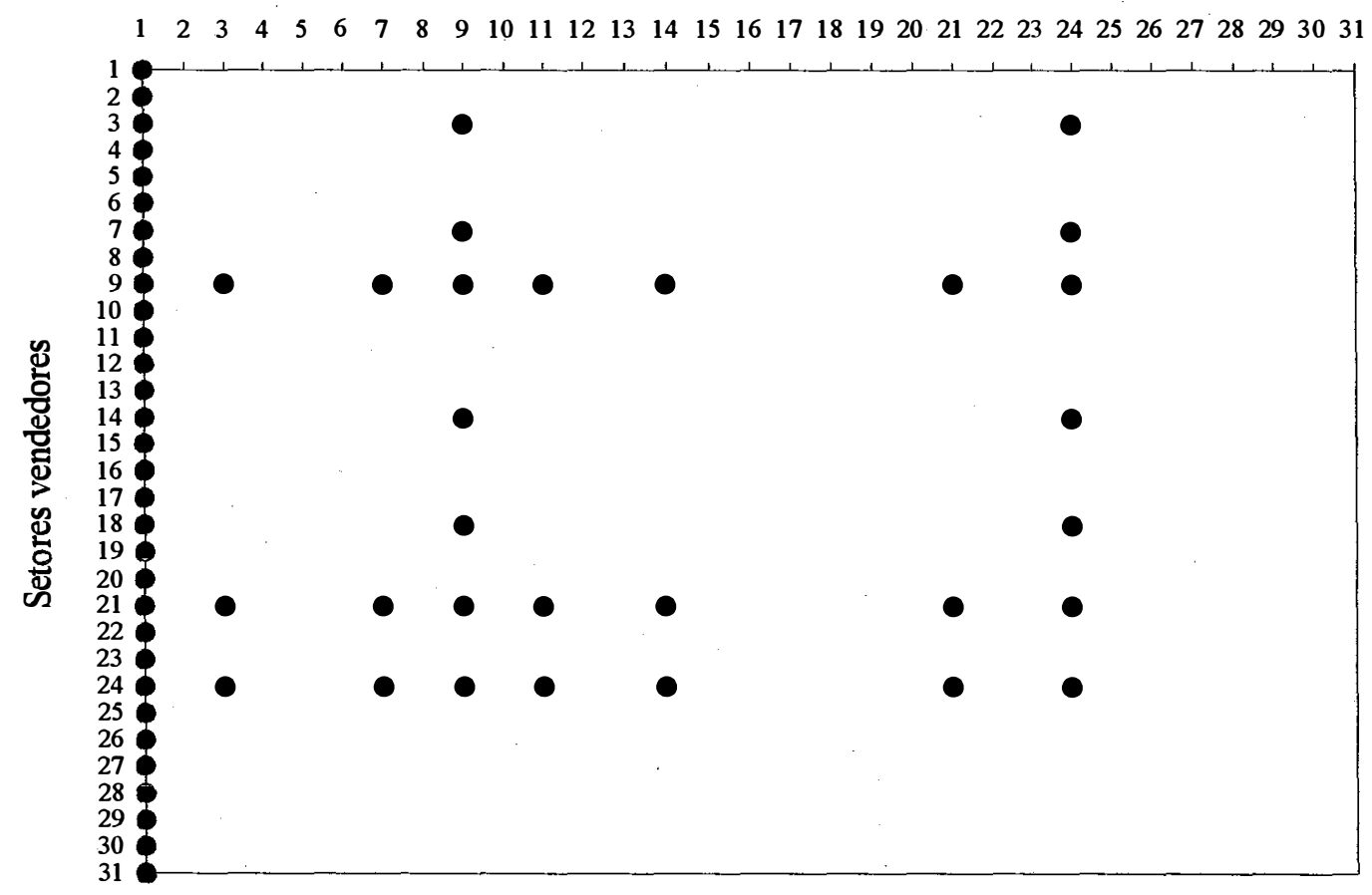

Figura 6.7 - Coeficientes setoriais com maior campo de influência, Paraná, 1995.

Os 250 coeficientes setoriais com maior campo de influência selecionados para o sistema econômico inter-regional paranaense revelam que os principais elos de ligações são dominados, em sua maior parte, por setores diretamente vinculados às economias do pólos regionais de Curitiba e Ponta Grossa (Figura 6.8). Pode-se dizer que a melhor articulação das indústrias do pólo regional de Curitiba, a elevada escala de produção e a proximidade geográfica com o pólo regional de Ponta Grossa explicam esse fato.

Nesse sentido, os setores Química (11) do pólo regional de Curitiba; Agropecuária (1), Celulose, Papel e Gráfica (9) e Serviços Industriais de Utilidade Pública (24) do pólo regional de Ponta Grossa; Agropecuária (1) do pólo regional de Londrina e Agropecuária (1) e Serviços Industriais de Utilidade Pública (24) do pólo regional de Cascavel são os que podem gerar grandes impactos sobre o sistema interregional paranaense, ou seja, as variações nos coeficientes diretos desses setores 
propiciam maior propagação das relações comerciais intersetoriais e inter-regionais para o sistema como um todo.

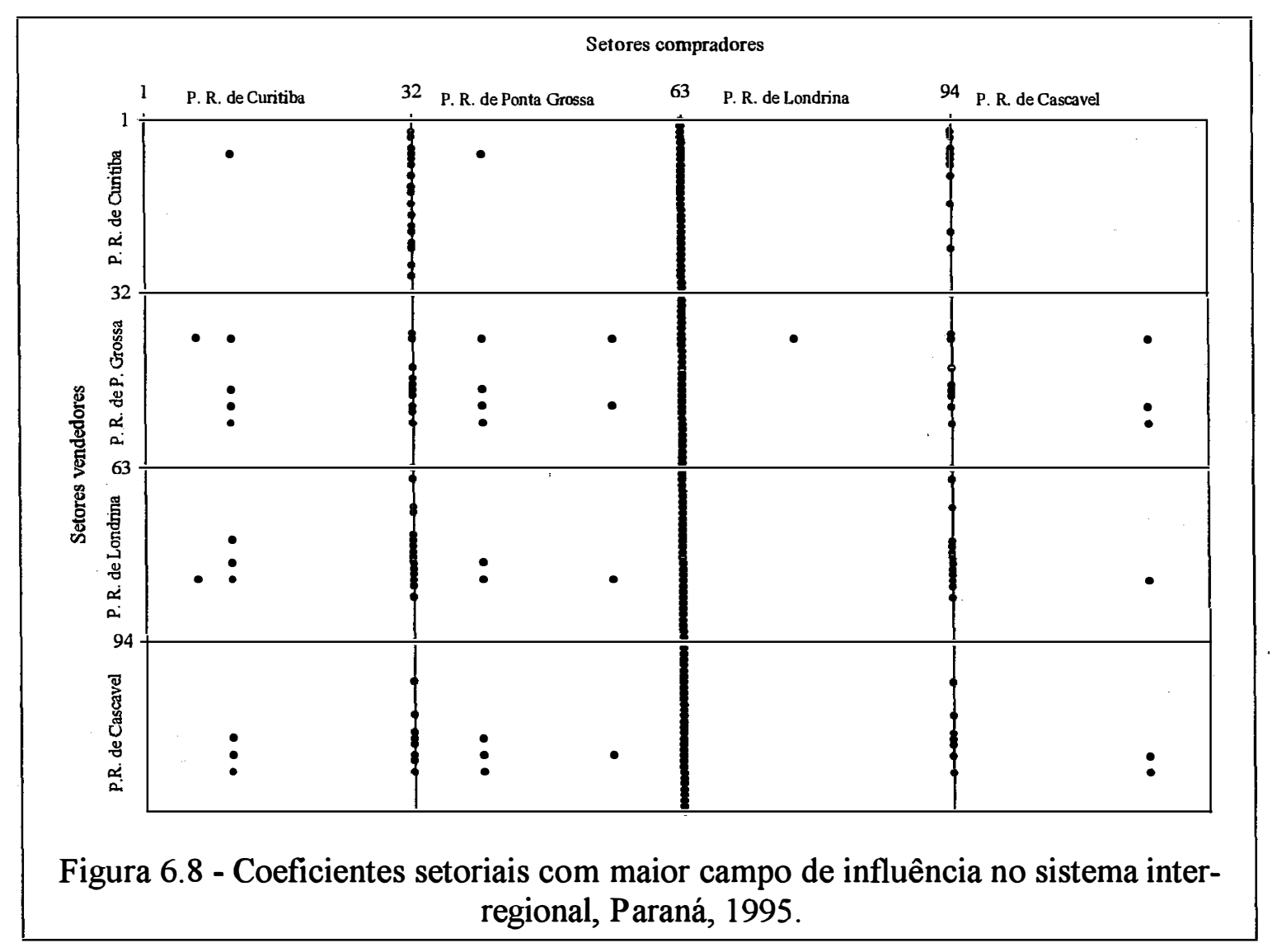

A título de exemplificação, o setor Química (11) do pólo regional de Curitiba movimentou, por meio de suas compras, principalmente os setores: Celulose, Papel e Gráfica (9), Abate de Animais (18), Fabricação de Óleos Vegetais (21) e Serviços Industriais de Utilidade Pública (24) no pólo regional de Ponta Grossa; Indústria Têxtil (14), Abate de Animais (18) e Fabricação de Óleos Vegetais (21) no pólo regional de Londrina; e Abate de Animais (18), Fabricação de Óleos Vegetais (21) e Serviços Industriais de Utilidade Pública (24) no pólo regional de Cascavel.

Por outro lado, cabe salientar que os elos de ligações mais relevantes entre os pólos regionais não se dão em duas direções, isto é, no mesmo sentido de compra e venda de produtos entre as regiões, notadamente para o setor Agropecuária (1) dos pólos 
regionais de Ponta Grossa, Londrina e Cascavel. Assim, o setor Agropecuária (1) do pólo regional de Londrina aciona todos os setores dos demais pólos componentes do sistema inter-regional enquanto comprador, ao passo que este mesmo setor dos pólos de Ponta Grossa e Cascavel dinamiza um número maior, porém, significativo de setores dentro do sistema econômico paranaense.

Resumido, os coeficientes com maior campo de influência indicam que existem enormes possibilidades de ampliar a interdependência industrial entre as regiões-pólo, por meio do comércio, via políticas de incentivos, principalmente naqueles setores com maior poder de encadeamento na estrutura produtiva paranaense.

\subsection{3 Índices puros de ligações para o Paraná}

Os índices de ligações de Rasmussen-Hirschman, apesar de largamente usados, são criticados por não considerar os diferentes níveis de produção em cada setor da economia. A abordagem do novo índice puro de ligações interindustriais, também denominada de GHS (Guilhoto et al. 1996), corrige esta deficiência ao medir a importância para o resto da economia em termos de seu valor da produção.

A Tabela 6.3 e a Figura 6.9 apresentam os índices de ligações para frente, para trás e total para o conjunto da economia do Paraná. Os campos hachurados representam valores acima da média. Considerando a soma dos índices para frente e para trás cujos valores superam a média estadual, tem-se os setores-chave na economia. Assim, pode-se verificar que o Paraná apresentou 12 setores-chave, sendo a maioria deles ligados ao setor serviço, com destaque para os setores Comércio (26), Outros Serviços (31) e Administração Pública (30). Vale destacar a importância do setor Agropecuária (1) como o principal setor-chave da economia paranaense em 1995.

Dentre os setores-chave, em termos de composição para frente, destacam-se os setores Química (11) com 95,8\%, Serviços Industriais de Utilidade Pública (24) e Outros Serviços (31) com 67,6\% e 62,0\%, respectivamente. O destaque em termos de composição para trás ficou com os setores Construção Civil (25), Administração Pública (30) e Madeira e Mobiliário (8), respectivamente, com 86,7\%, 86,3\% e 76,5\%. 
Tabela 6.3. Índices puros para frente, trás e total, Paraná,1995.

\begin{tabular}{|c|c|c|c|c|c|c|c|c|c|}
\hline & Setores & Frente & Ordem & Trás & Ordem & Total & Ordem & $\begin{array}{l}(\%) \\
\text { Trás }\end{array}$ & $\begin{array}{l}\text { (\%) } \\
\text { Frente }\end{array}$ \\
\hline 1 & Agropecuária & 2.0200002 & 3 & 1743.269 & 3 & 3.763 .271 & 1 & 46,3 & 53,7 \\
\hline 2 & Extrativa Mineral & 125.898 & 24 & 30.569 & 29 & 156.467 & 26 & 19,5 & 80,5 \\
\hline 3 & Fab. de Minerais não Metálicos & 612.356 & 8 & 76.246 & 25 & 688.602 & 16 & 11,1 & 88,9 \\
\hline 4 & Metalurgia & 300.673 & 16 & 112.967 & 22 & 413.639 & 22 & 27,3 & 72,7 \\
\hline 5 & Máquinas e Equipamentos & 416.543 & 11 & 174.381 & 19 & 590.924 & 18 & 29,5 & 70,5 \\
\hline 6 & Material Elétrico/Eletrônico & 324.090 & 15 & 460.751 & 14 & 784.841 & 14 & 58,7 & 41,3 \\
\hline 7 & Material de Transportes & 411.849 & 12 & 539.528 & 12 & 951.376 & 13 & 56,7 & 43,3 \\
\hline 8 & Madeira e Mobiliário & 266.352 & 19 & 868.297 & 6 & $1,134,649$ & 12 & 76,5 & 23,5 \\
\hline 9 & Celulose, Papel e Gráfica & 818.787 & 7 & 589330 & 11 & 1408117 & 9 & 41,9 & 58,1 \\
\hline 10 & Indústria da Borracha & 17.754 & 29 & 4.223 & 31 & 21.977 & 31 & 19,2 & 80,8 \\
\hline 11 & Química & 2227.727 & 1 & 98.319 & 24 & 2.326 .046 & 5 & 4,2 & 95,8 \\
\hline 12 & Ind. Farmacêutica e de Perfumaria & 25.784 & 27 & 130.094 & 20 & 155.878 & 27 & 83,5 & 16,5 \\
\hline 13 & Indústria de Artigos de Plásticos & 290.488 & 17 & 24.720 & 30 & 315.208 & 25 & 7,8 & 92,2 \\
\hline 14 & Indústria Têxtil & 277.294 & 18 & 117.869 & 21 & 395.163 & 24 & 29,8 & 70,2 \\
\hline 15 & Vestuário, Calçados, Couros e Peles & 23.724 & 28 & 395.939 & 16 & 419.663 & 20 & 94,3 & 5,7 \\
\hline 16 & Indústria do Café & 11.634 & 31 & 66.321 & 27 & 77.955 & 30 & 85,1 & 14,9 \\
\hline 17 & Beneficiamento de Produtos Vegetais & 160.025 & 23 & 513.567 & 13 & 673.593 & 17 & 76,2 & 23,8 \\
\hline 18 & Abate de animais & 79.824 & 25 & 623.023 & 10 & 702.847 & 15 & 88,6 & 11,4 \\
\hline 19 & Indústria de Laticínios & 12.876 & 30 & 100.470 & 23 & 113.346 & 28 & 88,6 & 11,4 \\
\hline 20 & Fabricação de Açúcar & 33.701 & 26 & 73.108 & 26 & 106.809 & 29 & 68,4 & 31,6 \\
\hline 21 & Fabricação de Óleos Vegetais & 206.100 & 22 & 299.879 & 17 & 505.979 & 19 & 59,3 & 40,7 \\
\hline 22 & Fab. de Outros Produtos Alimentares & 468.481 & 10 & 701.989 & 9 & 1.170 .470 & 11 & 60,0 & 40,0 \\
\hline 23 & Indústrias Diversas & 225.749 & 21 & 175.003 & 18 & 400.753 & 23 & 43,7 & 56,3 \\
\hline 24 & Serv. Ind. de Utilidade Pública & 893363 & 6 & 428.916 & 15 & $1.322,278$ & 10 & 32,4 & 67,6 \\
\hline 25 & Construção Civil & 264.261 & 20 & 1.725 .688 & 4 & 1.989949 & 6 & 86,7 & 13,3 \\
\hline 26 & Comércio & 1.792 .452 & 4 & 1.795 .907 & 2 & 3.588359 & 2 & 50,0 & 50,0 \\
\hline 27 & Transporte & 1.149047 & 5 & 751.197 & 8 & $1,900,243$ & 7 & 39,5 & 60,5 \\
\hline 28 & Comunicações & 362.842 & 13 & 52.646 & 28 & 415.488 & 21 & 12,7 & 87,3 \\
\hline 29 & Instituições Financeiras & 601.117 & 9 & 848.653 & 7 & 1.449 .770 & 8 & 58,5 & 41,5 \\
\hline 30 & Administração Pública & 332.793 & 14 & 2.099 .912 & 1 & $2,432,705$ & 4 & 86,3 & 13,7 \\
\hline 31 & Outros Serviços & $2,161,560$ & 2 & 1.324 .787 & 5 & 3.486 .347 & 3 & 38,0 & 62,0 \\
\hline & Média & 545.650 & & 546.696 & & 1.092 .346 & & 50,0 & 50,0 \\
\hline
\end{tabular}

Fonte: dados estimados pelo autor.

Os setores com altos índices para frente são os principais ofertantes na economia. Isso mostra que, por serem os mais demandados, sofrem maior impacto puro da produção total do resto da economia sobre estes setores. Se houver um crescimento generalizado da economia, os setores com os maiores índices de ligações para frente serão os mais impactados. Neste sentido, o conjunto da estrutura econômica paranaense apresentou 10 setores com fortes ligações para frente, com destaque para os setores Química (11), Outros Serviços (31) e Agropecuária (1). 


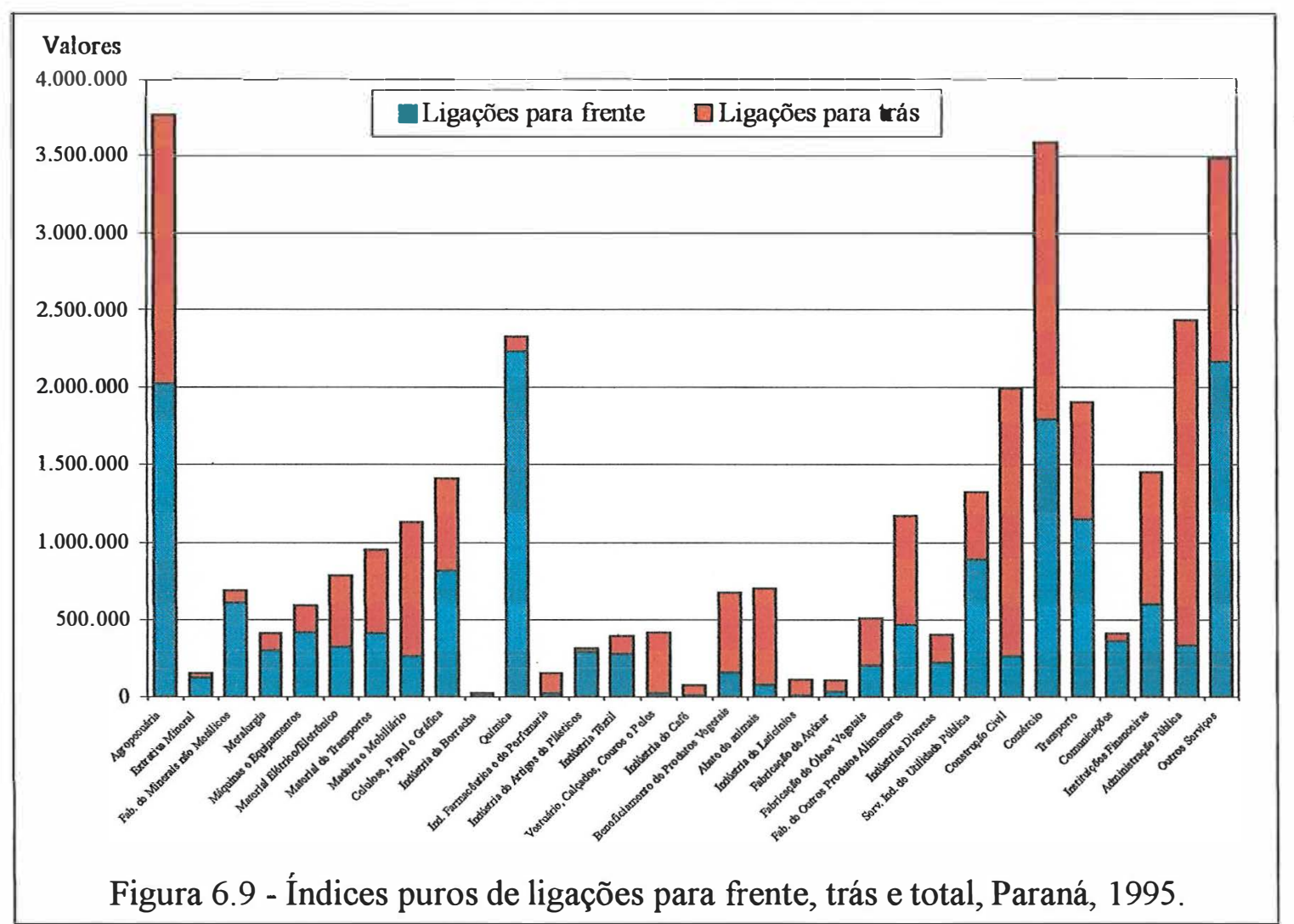

Por outro lado, os setores com altos índices puros de ligações para trás caracterizam-se como os principais demandantes dentro do sistema econômico. São esses setores que proporcionam os maiores impactos no resto da economia. Nesse aspecto, o Paraná apresentou 11 setores com altos índices puros para trás, sendo que pouco mais da metade estava diretamente relacionado ao ramo serviços. Dentre os setores com altos índices puros para trás, acima da média, merecem destaque os setores Administração Pública (30), Comércio (26), Agropecuária (1) e Construção Civil (25).

\subsubsection{1 Índices puros de ligações para o sistema inter-regional}

Os resultados dos índices puros de ligações para frente e para trás para o sistema inter-regional encontram-se expressos na Tabela 6.4 e nas Figuras 6.10 e 6.11 . Constatou-se, com base no valor da produção gerada pelas economia setoriais e das regiões-pólo, que a importância de cada pólo regional para a economia paranaense é 
bastante diferenciada, evidenciando uma supremacia do pólo regional de Curitiba e, em menor intensidade, do pólo regional de Londrina.

Em termos setoriais, os setores com índices puros de ligações para frente que mais se destacaram, dentro do sistema, foram os ligados às economias dos pólos regionais de Curitiba e Londrina, notadamente Química (11), Outros Serviços (31) e Comércio (26) no primeiro e Agropecuária (1) no segundo. Embora estas regiões-pólo respondam pela maior parte da produção estadual, o valor da produção para frente gerado nos pólos de Ponta Grossa e Cascavel não é desprezível, merecendo destaque os setores Agropecuária (1) e Celulose, Papel e Gráfica (9) para Ponta Grossa e Agropecuária (1) e Serviços Industriais de Utilidade Pública (24) para Cascavel. Esses setores com altos índices para frente e por serem os mais demandados, receberiam os maiores impactos se houvesse um crescimento geral da economia.

Com relação aos índices puros para trás, novamente, na economia dos pólos regionais de Curitiba e de Londrina aparecem os mais relevantes, entre os quais podemse destacar Administração Pública (30), Construção Civil (25), Comércio (26), Instituições Financeiras (29), Material de Transporte (7) e Material Elétrico/Eletrônico (6) para a primeira região-pólo e Agropecuária (1), Comércio (26), Administração Pública (30) e Construção Civil (25) para a segunda. Numa outra dimensão, os setores Agropecuária (1), Celulose, Papel e Gráfica (9) e Outros Serviços (31) para o pólo regional de Ponta Grossa e Agropecuária (1), Comércio (26) e Abate de Animais (18) para o pólo regional de Cascavel devem ser considerados importantes para o sistema inter-regional. Esses setores com os maiores índices puros de ligações para trás e por serem os principais demandantes dentro do sistema econômico, são os que podem propiciar os maiores impactos no resto da economia.

Para o pólo regional de Londrina, o setor Agropecuária (1) teve a maior composição do índice puro total representada pela parcela do índice para frente, $61,5 \%$, enquanto o setor Comércio (26) apresentou sua composição, praticamente, dividida entre os índices para trás e para frente, $50,3 \%$ e $49,7 \%$, respectivamente.

Com relação aos pólos regionais de Ponta Grossa e Cascavel, constatou-se que os principais setores-chave mostraram um certo equilíbrio no que se refere à 
composição do valor do índice puro total, exceto para o setor Serviços Industriais de Utilidade Pública (24) para o pólo regional de Cascavel, cujo maior parcela da composição do valor do índice puro total, $68,5 \%$, advém do índice para frente.

De modo geral, os resultados dos índices puros para o sistema inter-regional paranaense revelaram que a maioria dos setores vinculados ao ramo serviços são setoreschave para todos os pólos regionais.

Tabela 6.4. Índices puros de ligações para o sistema inter-regional, Paraná, 1995. (Em Mil Reais).

(continua)

\begin{tabular}{|c|c|c|c|c|c|c|c|c|c|c|}
\hline \multirow{2}{*}{$\begin{array}{c}\text { Pólos Regionais } \\
\text { e Setores }\end{array}$} & \multicolumn{5}{|c|}{ P. R. de Curitiba } & \multicolumn{5}{|c|}{ P. R. de Ponta Grossa } \\
\hline & Trás & Frente & Total & $\begin{array}{l}(\%) \\
\text { Trás }\end{array}$ & $\begin{array}{l}\text { (\%) } \\
\text { Frente }\end{array}$ & Trás & Frente & Total & $\begin{array}{l}\text { (\%) } \\
\text { Trás }\end{array}$ & $\begin{array}{l}\text { (\%) } \\
\text { Frente }\end{array}$ \\
\hline 1 Agropecuária & 191.310 & 48.870 & 240.180 & 79,7 & 20,3 & 509.023 & 570.641 & 10079664 & 47,1 & 52,9 \\
\hline 2 Extrativa Mineral & 22.974 & 100.031 & 123.005 & 18,7 & 81,3 & 4.230 & 16.687 & 20.917 & 20,2 & 79,8 \\
\hline 3 Fab. de Minerais não Metálicos & 56.964 & 537915 & 594.879 & 9,6 & 90,4 & 7.504 & 15.372 & 22.876 & 32,8 & 67,2 \\
\hline 4 Metalurgia & 63.792 & 253.102 & 316.894 & 20,1 & 79,9 & 18.128 & 17.050 & 35.179 & 51,5 & 48,5 \\
\hline 5 Máquinas e Equipamentos & 154.920 & 371605 & 526.525 & 29,4 & 70,6 & 4.232 & 10.938 & 15.171 & 27,9 & 72,1 \\
\hline 6 Material Elétrico/Eletrônico & 434.821 & 315253 & 750073 & 58,0 & 42,0 & 381 & 175 & 556 & 68,5 & 31,5 \\
\hline 7 Material de Transportes & 507.242 & 412.679 & 919921 & 55,1 & 44,9 & 10.543 & 3.859 & 14.403 & 73,2 & 26,8 \\
\hline 8 Madeira e Mobiliário & 351986 & 132.759 & 484.745 & 72,6 & 27,4 & 272711 & 73.291 & 346.002 & 78,8 & 21,2 \\
\hline 9 Celulose, Papel e Gráfica & 201.681 & 288.77 & 490.458 & 41,1 & 58,9 & 394196 & 540877 & 935073 & 42,2 & 57,8 \\
\hline 10 Indústria da Borracha & 843 & 10.446 & 11.289 & 7,5 & 92,5 & 560 & 1.161 & 1.721 & 32,5 & 67,5 \\
\hline 11 Quimica & 98.959 & 1.814339 & 1913,297 & 5,2 & 94,8 & -15972 & 92836 & 76.865 & $-20,8$ & 120,8 \\
\hline 12 Ind. Farmacêutica e de Perfumaria & 118.541 & 20.255 & 138.796 & 85,4 & 14,6 & 882 & 322 & 1.204 & 73,3 & 26,7 \\
\hline 13 Indústria de Artigos de Plásticos & 22.808 & 205.029 & 227.836 & 10,0 & 90,0 & 680 & 4.639 & 5.319 & 12,8 & 87,2 \\
\hline 14 Indústria Têxtil & 34.130 & 26.160 & 60.289 & 56,6 & 43,4 & 13.920 & 16.869 & 30.789 & 45,2 & 54,8 \\
\hline 15 Vestuário, Calçados, Couros e Peles & 87.365 & 6.095 & 93.459 & 93,5 & 6,5 & 8.993 & 777 & 9.769 & 92,1 & 8,0 \\
\hline 16 Indústria do Café & 25.305 & 5.135 & 30.440 & 83,1 & 16,9 & 4.902 & 1.213 & 6.115 & 80,2 & 19,8 \\
\hline 17 Benef. de Produtos Vegetais & 42.359 & 10.429 & 52.788 & 80,2 & 19,8 & 110783 & 36.171 & 146.953 & 75,4 & 24,6 \\
\hline 18 Abate de animais & 46.563 & 3.687 & 50.251 & 92,7 & 7,3 & 99,705 & 15.067 & 114.772 & 86,9 & 13,1 \\
\hline 19 Indústria de Laticinios & 6.613 & 787 & 7.400 & 89,4 & 10,6 & 31.477 & 3.966 & 35.443 & 88,8 & 11,2 \\
\hline 20 Fabricação de Açúcar & 1.888 & 900 & 2.787 & 67,7 & 32,3 & 1.341 & 723 & 2.064 & 65,0 & 35,0 \\
\hline 21 Fabricação de Óleos Vegetais & 105.131 & 32.706 & 137.837 & 76,3 & 23,7 & 81.984 & 51.759 & 133.743 & 61,3 & 38,7 \\
\hline 22 Fab. de Outros Prod. Alimentares & 363,614 & 117.535 & 481.150 & 75,6 & 24,4 & 51.830 & 88974 & 140.804 & 36,8 & 63,2 \\
\hline 23 Indústrias Diversas & 156.592 & 205.775 & 362.368 & 43,2 & 56,8 & 3.425 & 6.838 & 10.263 & 33,4 & 66,6 \\
\hline 24 Serv. Ind. de Utilidade Pública & 176.988 & 121.625 & 298.613 & 59,3 & 40,7 & 77.266 & 308.439 & 385704 & 20,0 & 80,0 \\
\hline 25 Construção Civil & 986990 & 157.146 & 1.144 .136 & 86,3 & 13,7 & 170.187 & 28.729 & 198916 & 85,6 & 14,4 \\
\hline 26 Comércio & 900.464 & 921.548 & 1.822 .012 & 49,4 & 50,6 & 170167 & 199,062 & 369.228 & 46,1 & 53,9 \\
\hline 27 Transporte & 334.875 & $\$ 52.185$ & 887,060 & 37,8 & 62,2 & 104.676 & 150.843 & 255519 & 41,0 & 59,0 \\
\hline 28 Comunicações & 18.100 & 227.558 & 245.657 & 7,4 & 92,6 & 4.993 & 25.244 & 30.237 & 16,5 & 83,5 \\
\hline 29 Instituições Financeiras & 693.035 & 504.535 & 1.197 .570 & 57,9 & 42,1 & 35.918 & 23.195 & 59.113 & 60,8 & 39,2 \\
\hline 30 Administração Pública & 1.248 .959 & 220.172 & 1.469130 & 85,0 & 15,0 & 217.888 & 31.441 & 249.329 & 87,4 & 12,6 \\
\hline 31 Outros Serviços & 594.262 & $1,272,461$ & 1866.723 & 31,8 & 68,2 & 292.997 & 277.792 & 570789 & 51,3 & 48,7 \\
\hline Médja & 259.680 & 287.016 & 546.696 & 47,5 & 52,5 & 86.760 & 84.353 & 171.113 & 50,2 & 49.3 \\
\hline
\end{tabular}

Fonte: dados estimados pelo autor. 
Tabela 6.4. Índices puros de ligações para o sistema inter-regional, Paraná, 1995. (Em Mil Reais)

\begin{tabular}{|c|c|c|c|c|c|c|c|c|c|c|}
\hline \multirow{3}{*}{$\begin{array}{c}\text { Pólos Regionais } \\
\text { e Setores }\end{array}$} & \multicolumn{5}{|c|}{ P. R. de Londrina } & \multicolumn{5}{|c|}{ P. R. de Cascavel } \\
\hline & Trás & Frente & Total & $(\%)$ & $(\%)$ & Trás & Frente & Total & $(\%)$ & $(\%)$ \\
\hline & \multicolumn{5}{|c|}{ Trás Frente } & \multicolumn{5}{|c|}{ Trás Frente } \\
\hline 1 Agropecuária & 638.515 & 1021.870 & 1.66038 & 38,5 & 61,5 & 537.402 & 516,610 & 1.054012 & 51,0 & 49,0 \\
\hline $2 \mathrm{Ext}$ & 1.784 & 5.194 & 6.978 & 25,6 & 74,4 & 1.676 & 3.949 & 5.625 & 29,8 & 70,2 \\
\hline 3 Fab. de Minerais não Metálicos & 12.428 & 52.316 & 64.744 & 419,2 & 80,8 & 6.049 & 13.897 & 19.946 & 30,3 & 69,7 \\
\hline 4 Metalurgia & 23.657 & 23.145 & 46.802 & 50,5 & 49,5 & 14.531 & 9.980 & 24.511 & 59,3 & 40,7 \\
\hline 5 Máquinas e E & 12.918 & 24.123 & 37.041 & 34,9 & 65,1 & 3.918 & 8.329 & 12.247 & 32,0 & 68,0 \\
\hline 6 Material Elétr & 29.998 & 14.646 & 44.643 & 67,2 & 32,8 & 1.016 & 676 & 1.692 & 60,0 & 40,0 \\
\hline 7 Materia & 2.078 & 11.839 & 43.917 & 73,0 & 27,0 & 4.300 & 1.535 & 5.835 & 73,7 & 26,3 \\
\hline 8 Madeira e Mobiliário & 7,954 & 67.636 & 255.591 & 73,5 & 26,5 & 87.965 & 20.132 & 108.097 & 81,4 & 18,6 \\
\hline 9 Celulose, Papel e Gráfica & 32.685 & 29.556 & 62.241 & 152,5 & 47,5 & 15.420 & 11.120 & 26.541 & 58,1 & 41,9 \\
\hline 10 Indústria da Borracha & 2.086 & 4.083 & 6.169 & 33,8 & 66,2 & 830 & 1.517 & 2.347 & 35,4 & 64,6 \\
\hline 11 Química & 17.668 & 311228 & 328.896 & 5,4 & 94,6 & -1221 & 11.327 & 10.107 & $-12,1$ & 112,1 \\
\hline 12 Ind. Farmacêu & 9.576 & 3.364 & 12.940 & 074,0 & 26,0 & 1.552 & 504 & 2.056 & 75,5 & 24,5 \\
\hline 13 Indústria de Artigos de Plásticos & 277 & 77.430 & 77.707 & $\begin{array}{l}7 \\
0,4\end{array}$ & 99,6 & 999 & 4.028 & 5.026 & 19,9 & 80,1 \\
\hline 14 Indústria Têxtil & 76.650 & 235962 & 312612 & 24,5 & 75,5 & 10.405 & 15.947 & 26.351 & 39,5 & 60,5 \\
\hline 15 Vestuário, Calçado & 259.670 & 19.315 & 278985 & 93,1 & 6,9 & 46.749 & 3.775 & 50.524 & 92,5 & 7,5 \\
\hline 16 Indústria do Café & 37.969 & 8.537 & 46.506 & 681,6 & 18,4 & 1.755 & 279 & 2.034 & 86,3 & 13,7 \\
\hline 17 Benef. de Produtos & 211.764 & 81.510 & 293.274 & 472,2 & 27,8 & 148.850 & 34.372 & 183.222 & 81,2 & 18,8 \\
\hline 18 Abate de animais & 237850 & 42.410 & 280,260 & 84,9 & 15,1 & 241.290 & 22.001 & & 91,6 & 8,4 \\
\hline 19 Indústria de Laticí & 35.431 & 6.072 & 41.504 & 485,4 & 14,6 & 26.947 & 2.892 & 29.838 & 90,3 & 9,7 \\
\hline 20 Fabricação de Açúcar & 69.805 & 31.929 & 101.734 & 468,6 & 31,4 & - & - & - & 9 & \\
\hline 21 Fabricaçã & 78.178 & 91.086 & 169.264 & 446,2 & 53,8 & 46.746 & 43.038 & 89.784 & 52,1 & 47,9 \\
\hline 22 Fab. de Outros Pro & 247206 & 193344 & 440,55 & 56,1 & 43,9 & 49.913 & 75.785 & 125.698 & 39,7 & 60,3 \\
\hline 23 Indústrias Diversas & 11.010 & 10.870 & 21.880 & 050,3 & 49,7 & 3.149 & 3.052 & 6.201 & 50,8 & 49,2 \\
\hline 24 Serv. Ind. de Utilida & 121.832 & 159.444 & 281.275 & 543,3 & 56,7 & 213.763 & 464.519 & 678.281 & 31,5 & 68,5 \\
\hline 25 Construção Civil & 382.103 & 64.126 & 446,229 & 85,6 & 14,4 & 200765 & 28.302 & 229067 & 87,6 & 12,4 \\
\hline 26 Comércio & 469560 & 464.828 & 934.388 & 850,3 & 49,7 & 279.295 & 233.517 & 512.812 & 54,5 & 45,5 \\
\hline 27 Transporte & 178.482 & 2981124 & 476606 & 63,4 & 62,6 & 147265 & 162620 & 309885 & 47,5 & 52,5 \\
\hline 28 Comunicações & 21.359 & 78.055 & 99.414 & 421,5 & 78,5 & 8.366 & 31.893 & 40.259 & 20,8 & 79,2 \\
\hline 29 Instituições Finan & 115.379 & 80.247 & 195.626 & 659,0 & 41,0 & 38.465 & 28.301 & 66.766 & 57,6 & 42,4 \\
\hline 30 Administração Pública & 435,281 & 67.674 & 502956 & 686,5 & 13,5 & 194327 & 28.364 & 222691 & 87,3 & 12,7 \\
\hline 31 Outros Serviços & 316,511 & 450.094 & 766,605 & 541,3 & 58,7 & 137,722 & 165.081 & 302,803 & 45,5 & 54,5 \\
\hline & 138.957 & 130.002 & 268.959 & 951,7 & 48,3 & 82.340 & 64.911 & 147.252 & 55,9 & 44,1 \\
\hline
\end{tabular}

Fonte: dados estimados pelo autor.

Com relação aos setores componentes da indústria de transformação, dois fatos merecem destaque. $\mathrm{O}$ primeiro refere-se à indústria de produtos alimentares. Apenas os pólos regionais de Londrina e Cascavel apresentaram setores-chave, três em Londrina e dois em Cascavel. O segundo diz respeito à considerada indústria de base, cujos setores-chave concentraram no pólo regional de Curitiba. É notória a ausência de indústrias desta natureza nos demais pólos. 

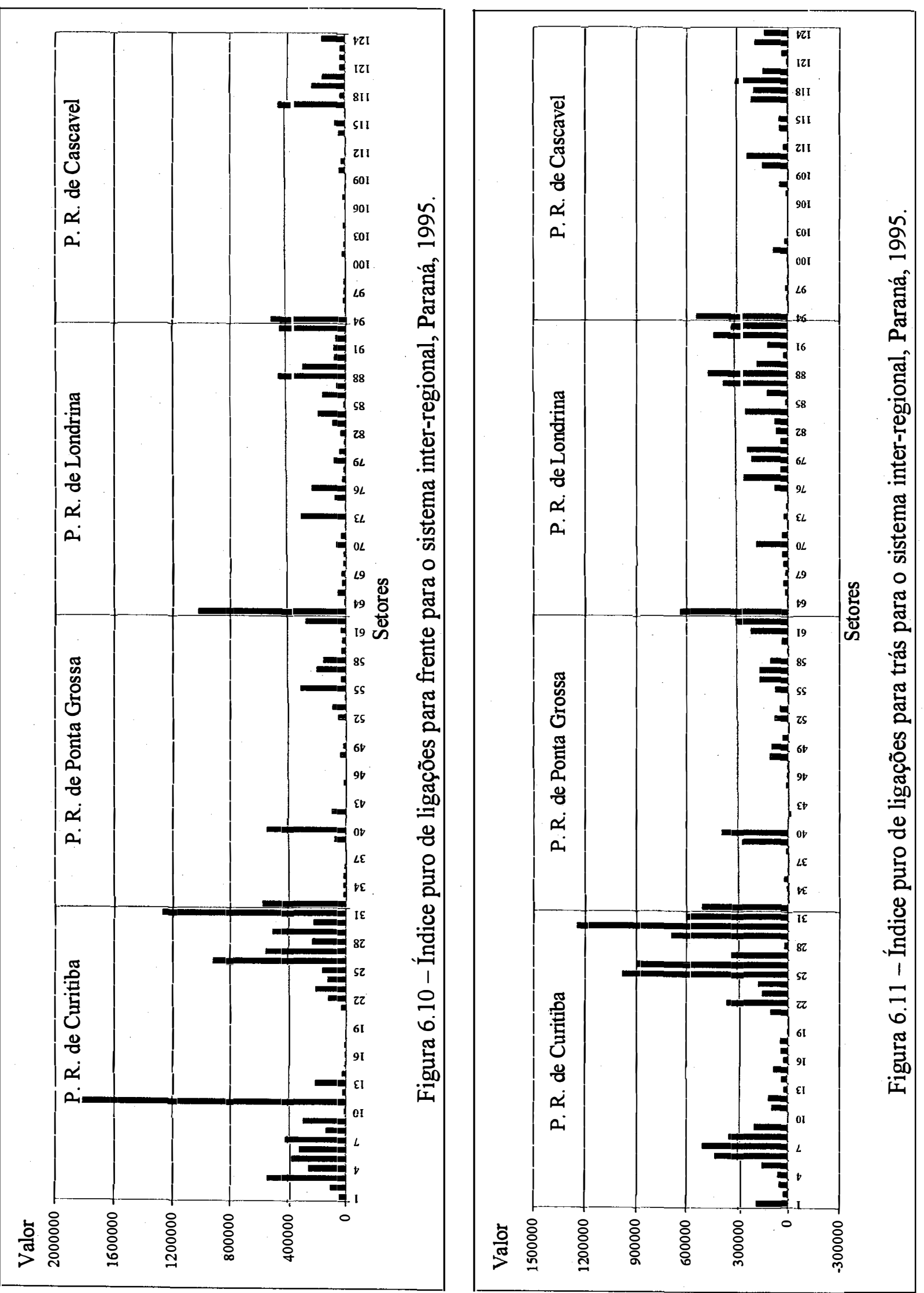
Sintetizando, de acordo com o valor da produção que geram os pólos regionais, os índices puros revelaram a importância relativa do pólo regional de Curitiba sobre os demais pólo componentes do sistema inter-regional. Isso assegura que o perfil de uma maior reciprocidade ou integração econômica na economia paranaense será estabelecido ou induzido pelo pólo regional de Curitiba.

\subsubsection{Comparação e consolidação dos índices de Rasmussem-Hirschman e puros}

A comparação dos índices de Rasmussem-Hirschman e puro total para o sistema inter-regional revelou uma classificação diferente para os setores-chave. $\mathbf{O}$ segundo apresenta um número maior de setores dinâmicos na economia. Isto deve-se ao fato de que, nos índices de Rasmussem-Hirschman, o mais importante para a definição de setores-chave é a estrutura interna da economia, independente do valor da produção total na economia, enquanto os índices puros consideram não apenas a estrutura interna mas, também, o nível de produção em cada setor da economia.

Nesse sentido, Guilhoto (1995) salienta que os índices de RasmussemHirschman e os puros apresentam resultados que se complementam na identificação da estrutura produtiva. Os primeiros identificam o que pode se considerar como o potencial dos impactos de mudanças em um dado setor, enquanto os índices puros mostram os efeitos obtidos por meio de consideração do volume de produção. Portanto, não se deve esperar, como resultado, os mesmos setores-chave para a estrutura econômica com o emprego destas técnicas.

Observando-se as Tabelas 6.2, 6.3 e 6.4 e confrontando os resultados das ligações para frente dos índices de Rasmussem-Hirschman e dos puros constata-se certa similaridade no que se refere à classificação de setor-chave na economia paranaense. Nesse sentido, ambos os métodos revelam a importância dos impactos de mudanças em um dado setor, bem como do volume de produção. No entanto, as diferenças ocorreram nas ligações para trás, em que os índices puros se concentraram de forma mais acentuada, nos setores vinculados ao ramo serviços, enquanto o outro método 
evidenciou que as ligações para trás concentraram-se mais nos setores da indústria de transformação, notadamente a indústria alimentar.

A Tabela 6.5 apresenta a consolidação dos setores-chave encontrados pelos índices de Rasmussem-Hirschman, via critério restrito, e pelos índices puros totais, com valores acima da média, para o Paraná e para as regiões-pólo da economia paranaense. Percebe-se claramente um número maior de setores-chave usando o critério de índices puros do que empregando o critério restrito.

Tabela 6.5. Setores-chave consolidados - índices de ligações de Rasmussen-Hirschman (R-H) e os índices puros totais, Paraná e sistema inter-regional, 1995.

\begin{tabular}{|c|c|c|c|c|c|c|c|c|c|c|}
\hline \multirow{2}{*}{$\begin{array}{c}\text { Pólos Regionais } \\
\text { e Setores }\end{array}$} & \multicolumn{2}{|c|}{$\begin{array}{l}\text { P. R de } \\
\text { Curitiba }\end{array}$} & \multicolumn{2}{|c|}{$\begin{array}{c}\text { P. R de } \\
\text { Ponta Grossa }\end{array}$} & \multicolumn{2}{|c|}{$\begin{array}{l}\text { P. R de } \\
\text { Londrina }\end{array}$} & \multicolumn{2}{|c|}{$\begin{array}{l}\text { P. R de } \\
\text { Cascavel }\end{array}$} & \multicolumn{2}{|c|}{$\begin{array}{c}\text { Paraná } \\
\end{array}$} \\
\hline & $\mathrm{R}-\mathrm{H}$ & 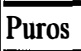 & $\overline{\mathrm{R}-\mathrm{H}}$ & Puros & $\mathrm{R}-\mathrm{H}$ & Puros & $\mathrm{R}-\mathrm{H}$ & Puros & R-H & Puros \\
\hline 1 Agropecuária & & & & $\oplus$ & & $\bar{\oplus}$ & & $\bar{\oplus}$ & & $\bar{\theta}$ \\
\hline 2 Extrativa Mineral & & & & & & & & & & \\
\hline \begin{tabular}{l|l}
3 & Fab. de Minerais não Metálicos \\
\end{tabular} & $\oplus$ & $\oplus$ & & & & & & & & \\
\hline 4 Metalurgia & & & & & & & & & & \\
\hline \begin{tabular}{l|l}
5 & Máquinas e Equipamentos \\
\end{tabular} & & & & & & & & & & \\
\hline \begin{tabular}{l|l}
6 & Material Elétrico/Eletrônico \\
\end{tabular} & & $\oplus$ & & & & & & & & \\
\hline \begin{tabular}{l|l}
7 & Material de Transportes \\
\end{tabular} & & $\oplus$ & & & & & & & & \\
\hline 8 Madeira e Mobiliário & & & & $\oplus$ & & & & & & $\oplus$ \\
\hline \begin{tabular}{l|l}
9 & Celulose Papel e Gráfica \\
\end{tabular} & $\oplus$ & & $\oplus$ & $\oplus$ & & & & & $\oplus$ & $\oplus$ \\
\hline \begin{tabular}{|l|l|}
10 & Indústria da Borracha \\
\end{tabular} & & & & & & & & & & \\
\hline \begin{tabular}{l|l}
1 & Química \\
\end{tabular} & & $\oplus$ & & & & $\oplus$ & & & & $\oplus$ \\
\hline \begin{tabular}{l|l}
12 & Ind. Farmacêutica e de Perfumaria \\
\end{tabular} & & & & & & & & & & \\
\hline 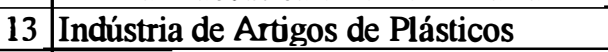 & & & & & & & & & & \\
\hline \begin{tabular}{l|l|l}
14 & Indústria Têxtil \\
\end{tabular} & & & & & $\Phi$ & $\oplus$ & & & $\oplus$ & \\
\hline \begin{tabular}{|l|l|l|l}
15 & Vestuário Calçados Couros e Peles \\
\end{tabular} & & & & & & $\oplus$ & & & & \\
\hline 16 Indústria do Café & & & & & & & & & & \\
\hline 17 Beneficiamento de Produtos Vegetais & & & & & & $\oplus$ & & $\oplus$ & & \\
\hline 18 Abate de animais & & & & & & $\oplus$ & & $\oplus$ & & \\
\hline 19 |Indústria de Laticínios & & & & & & & & & & \\
\hline 20 |Fabricação de Açúcar & & & & & & & & & & \\
\hline 21 |Fabricação de Oleos Vegetais & & & & & & & & & & \\
\hline 22 Fab. de Outros Produtos Alimentares & & & & & & $\oplus$ & & & & $\oplus$ \\
\hline 23 |Indústrias Diversas & & & & & & & & & & $\oplus$ \\
\hline 24 Serv. Ind. de Utilidade Pública & & & & $\oplus$ & & $\oplus$ & & $\oplus$ & & $\oplus$ \\
\hline 25 |Construção Civil & & $\oplus$ & & $\oplus$ & & $\oplus$ & & $\oplus$ & & $\oplus$ \\
\hline $26 \mid$ Comércio & & $\oplus$ & & $\oplus$ & & $\oplus$ & & $\oplus$ & & $\oplus$ \\
\hline \begin{tabular}{|l|l|l|}
27 & Transporte \\
\end{tabular} & & $\oplus$ & & $\oplus$ & & $\oplus$ & & $\oplus$ & & $\oplus$ \\
\hline $28 \mid$ Comunicações & & & & & & & & & & \\
\hline \begin{tabular}{|l|l}
29 & Instituições Finceiras \\
\end{tabular} & & $\oplus$ & & & & & & & & $\oplus$ \\
\hline 30 |Administração Pública & & $\oplus$ & & $\oplus$ & & $\oplus$ & & $\oplus$ & & $\oplus$ \\
\hline 31 Outros Serviços & & $\oplus$ & & $\oplus$ & & $\oplus$ & & $\oplus$ & & $\oplus$ \\
\hline
\end{tabular}

Fonte: Tabelas 6.2, 6.3 e 6.4 . 
Considerando o critério mais restrito, podem-se verificar 3 setores-chave para o sistema inter-regional e apenas 1 para a economia do Paraná com um todo. Assim, os setores Fabricação de Minerais não Metálicos (3), Celulose, Papel e Gráfica (9) e Indústrias Têxteis (14) são considerados setores-chave, respectivamente, para os pólos regionais de Curitiba, Ponta Grossa e Londrina. O setor Celulose, Papel e Gráfica (9) seria o setor-chave para o Paraná, enquanto o pólo regional de Cascavel não apresentaria setor-chave quando se emprega este critério. Do ponto de vista das estruturas de produção e do valor da produção gerada, estes setores devem ser considerados para uma mais rápida e maior interdependência da economia do sistema inter-regional paranaense.

\subsection{Matriz de intensidade e as diferentes estruturas econômicas}

Com o propósito de comparar as estruturas econômicas dos pólos regionais, foram utilizadas as matrizes de insumo-produto construídas para cada região e a do Paraná para o ano de 1995. A comparação da estrutura econômica das regiões foi feita usando as medidas de intensidade descritas na seção 5.2 do capítulo 5. Decidiu-se adotar a estrutura da economia do Paraná como base de comparação. Assim, a hierarquia dos fluxos, retratada pela matriz intensidade do Paraná, está associada à ordem das linhas e colunas, de maneira que os desvios da hierarquia do Paraná são claramente visíveis, permitindo, desta forma, examinar a natureza das diferenças entre as regiões.

A estrutura da economia do Estado do Paraná está retratada na Figura 6.12. Nela, as linhas representam a hierarquia dos índices de ligações para frente, enquanto as colunas, a dos índices de ligações para trás. $\mathrm{O}$ pico da hierarquia da estrutura econômica do Paraná ocorreu na interseção dos setores Agropecuária (1) e Fabricação de Óleos Vegetais (21), seguido pelos setores Quimica (11) e Abate de Animais (18). Nota-se que as maiores elevações ocorreram nos três primeiros cruzamentos, enquanto os demais revelam pequenas variações na elevação.

A matriz intensidade para os pólos regionais de Curitiba, Ponta Grossa, Londrina e Cascavel, construidas e ordenadas hierarquicamente seguindo a ordem 
derivada para o Paraná, são mostradas nas Figuras 6.13 até 6.16. Se todas as economias tivessem uma estrutura econômica similar, as hierarquias seriam idênticas e a topografia econômica seria muito semelhante.

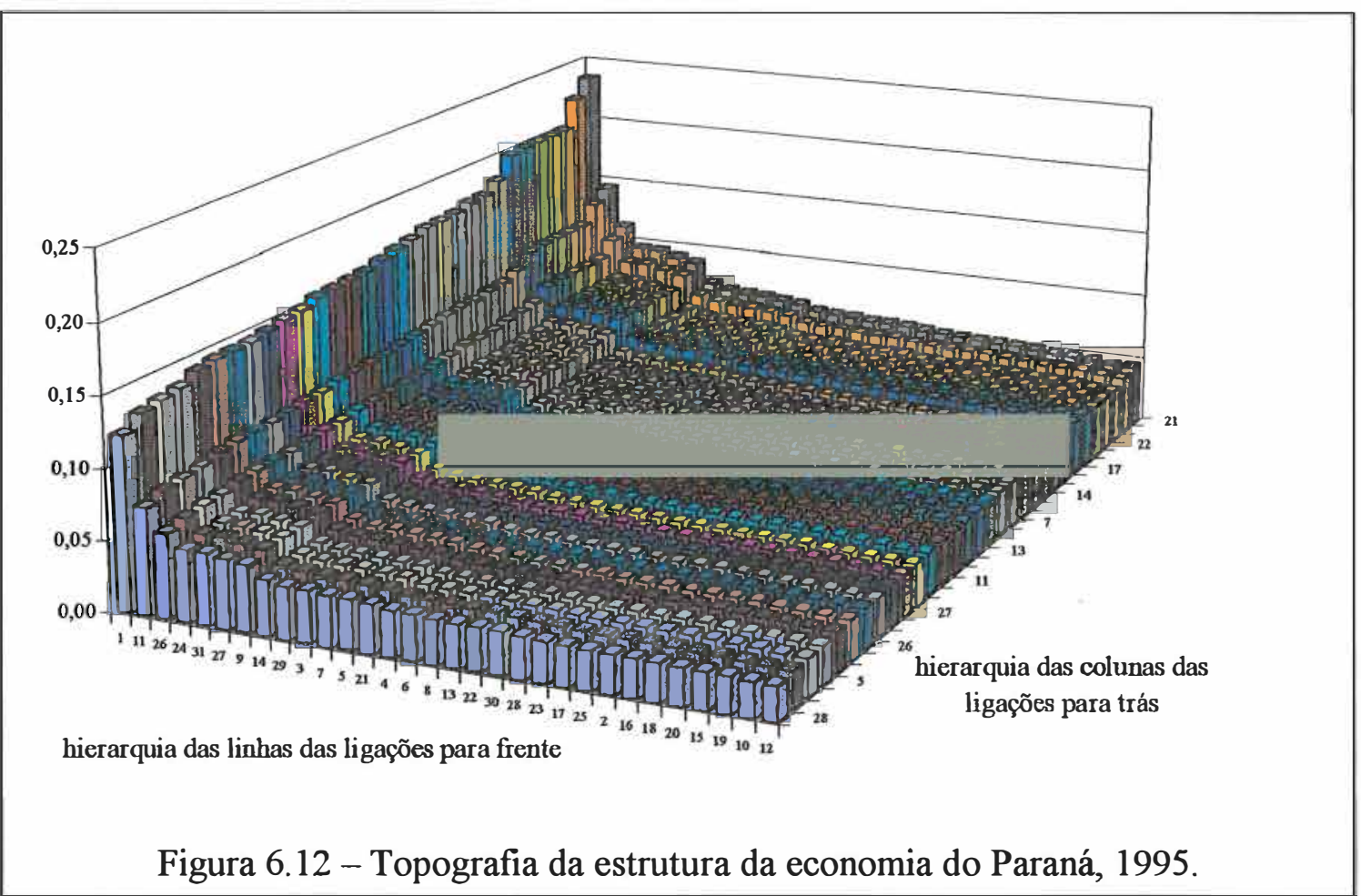

Observando as Figuras 6.14, 6.15 e 6.16, pode-se verificar que a estrutura econômica dos pólos regionais de Londrina, Ponta Grossa e Cascavel são semelhantes e apresentam características similares à estrutura econômica do Paraná.

A economia do pólo regional de Curitiba apresentou uma graduação menos nítida em comparação com a do Paraná (Figura 6.13). Nesta região, verificou-se que o pico mais elevado se deu com o cruzamento dos setores Química (11) e Material de Transportes (7), ambos importantes para a economia da região. Pode-se destacar, ainda, os cruzamentos do setor Química (11) com os setores Fabricação de Minerais não Metálicos (3) e Celulose, Papel e Gráfica (9).

No que se refere ao pólo regional de Londrina, verificou-se uma queda mais visível entre o primeiro e o segundo cruzamento, quando comparado com a estrutura 
econômica do Paraná. Nesta região, o pico mais elevado ocorreu no cruzamento dos setores Agropecuária (1) e Fabricação de Óleos Vegetais (21), ambos tendo importante papel econômico para a região. É evidente, também, a importância do setor Comércio (26) nesse pólo regional. Após o nono cruzamento, há pequenas variações nas elevações, revelando uma topografia econômica pouco pronunciada (Figura 6.14).

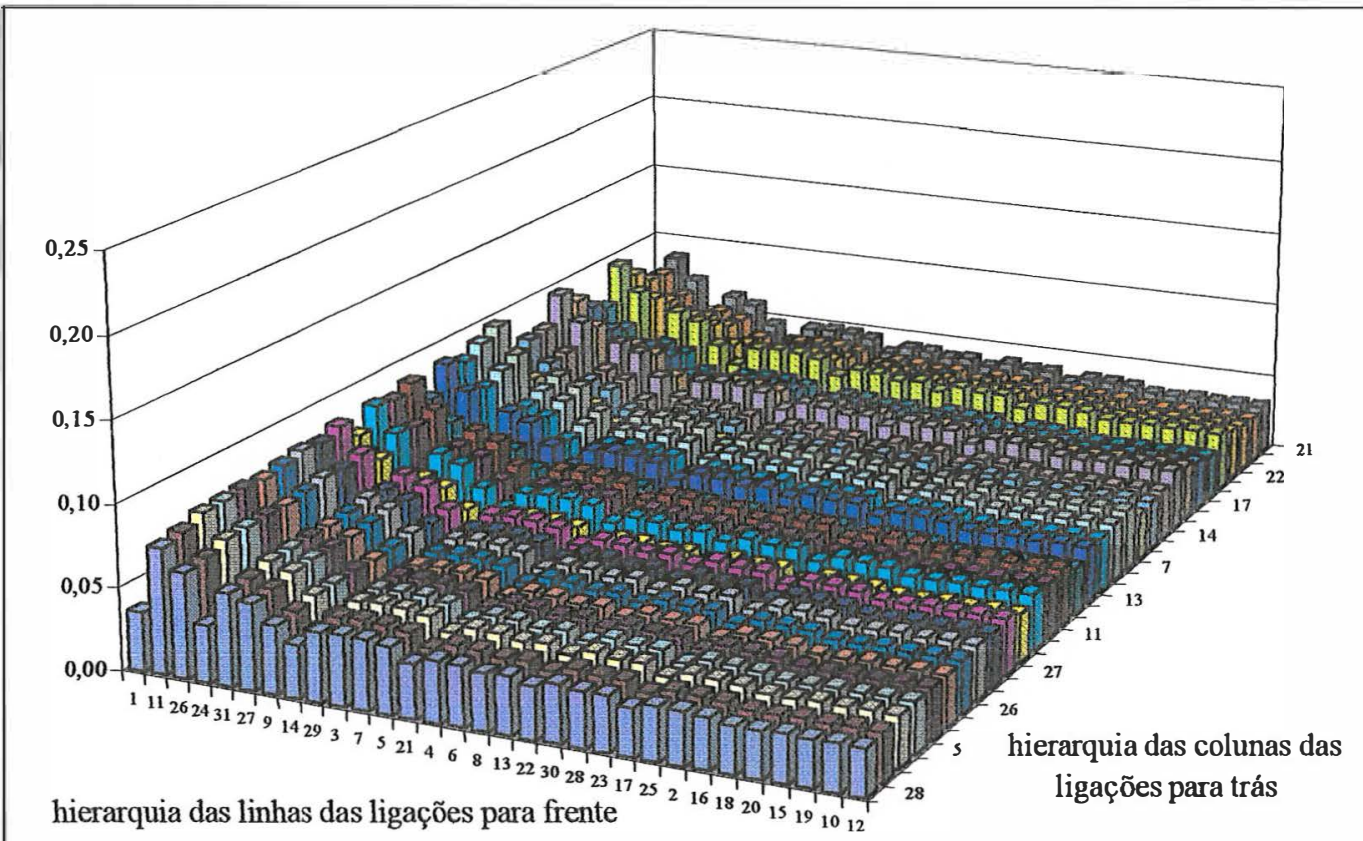

Figura 6.13 - Topografia da estrutura da economia do P. R. de Curitiba usando a hierarquia do Paraná, 1995.

Para o pólo regional de Ponta Grossa, observou-se uma notável queda entre o primeiro e o segundo cruzamento, diferentemente do verificado para a economia do Paraná. O ponto mais alto ocorreu com os cruzamentos do setor Agropecuária (1) com os setores Fabricação de Óleos Vegetais (21) e Abate de Animais (18), os quais têm um papel significativo na economia desta região-pólo (Figura 6.15).

No tocante ao o pólo regional de Cascavel, observou-se que sua estrutura econômica é bastante similar à de Londrina. Nesta região o setor Fabricação de Açúcar (20) não apresentou produção, gerando um vácuo no cruzamento deste setor com os demais. A exemplo do que foi visto para a região de Londrina, o setor Agropecuária 
(1)apresenta as maiores elevações, cujo pico ocorre no cruzamento com o setor Fabricação de Óleos Vegetais (21), sendo ambos, relevantes para o sistema econômico desta região. Cabe, ainda, salientar a importância dos setores Serviços Industriais de Utilidade Pública (24), Transporte (27), Comércio (26), Outros Serviços (31) e Abates de Animais (18) para a produção desse pólo regional (Figura 6.16).

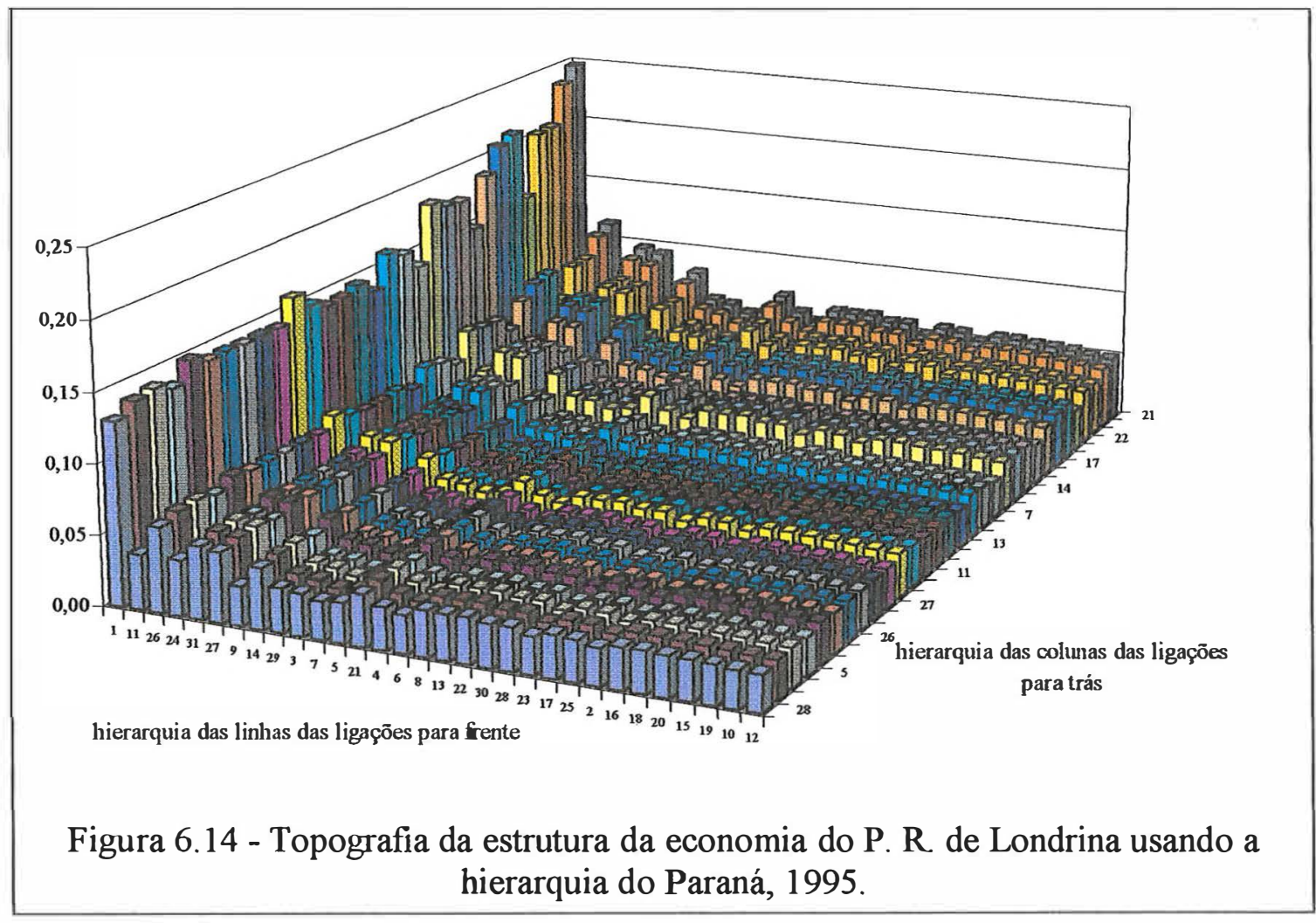

Finalmente, pode-se concluir que as estruturas econômicas dos pólos regionais são diferentes do sistema econômico paranaense. Isto permite diferenciar dois grupos: um que apresenta a estrutura da economia mais interligada, o caso da economia do pólo regional de Curitiba, e o outro, em que os sistemas econômicos das regiões apresentam-se menos interligados, fato observado para os pólos regionais de Londrina, Ponta Grossa e Cascavel. 


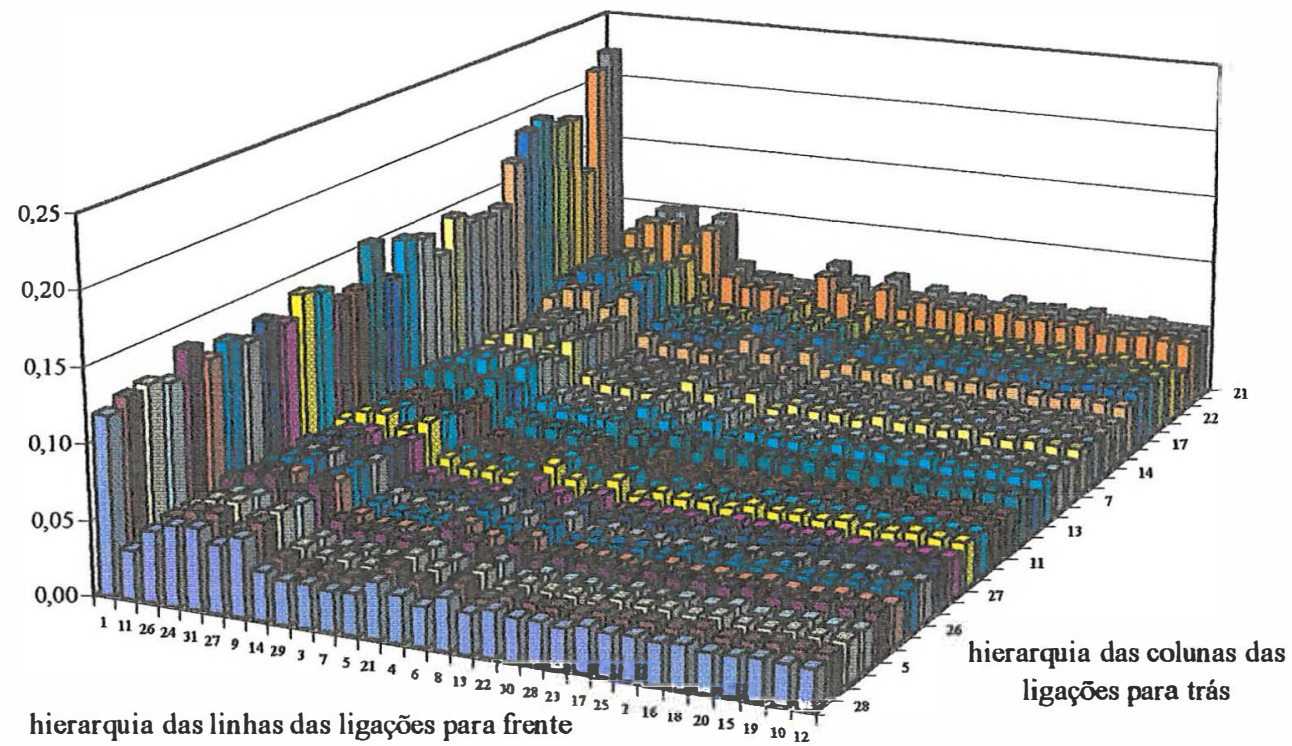

Figura 6.15 - Topografia da estrutura da economia do P. R. de Ponta Grossa usando a hierarquia do Paraná, 1995.

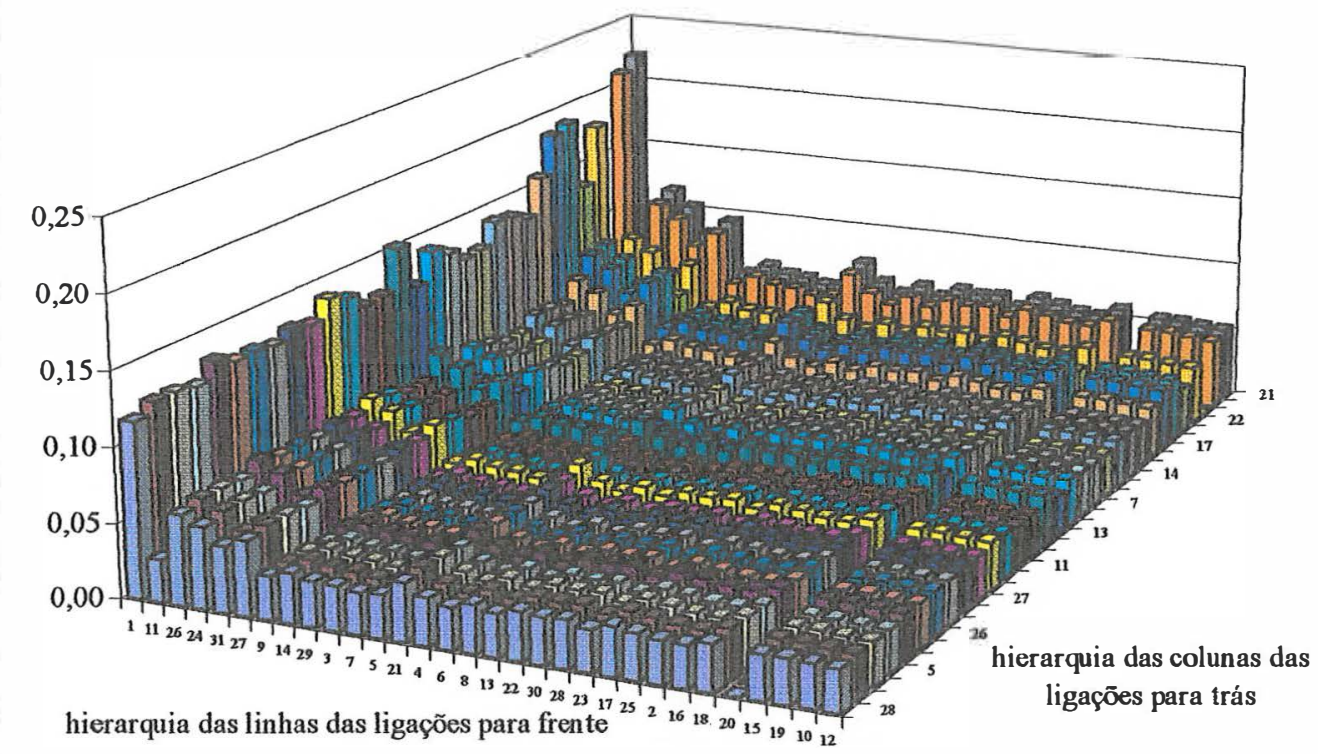

Figura 6.16 - Topografia da estrutura da economia do P. R. de Cascavel usando a hierarquia do Paraná, 1995. 


\subsection{Interações entre as regiões-pólo paranaense}

A análise desenvolvida até o presente momento considerou os setores de forma isolada, ou seja, dentro de cada pólo regional. O propósito desta seção é verificar o comportamento de cada pólo regional em termos de suas ligações com os outros pólos do sistema inter-regional, o que possibilita examinar a intensidade e o dimensionamento das interações entre eles.

O Pólo regional de Curitiba foi o mais importante receptor de impacto puro do valor da produção total do sistema, apresentando o maior índice puro de ligação para frente, $48,58 \%$. Neste pólo, o valor da produção total foi, também, o grande responsável por propiciar impacto ao resto da economia, uma vez que deteve os maiores valores do índice puro de ligação para trás, 33,44\% (Tabela 6.6). Nota-se que os outros pólos apresentaram um patamar semelhante enquanto receptores de impactos do valor da produção total do sistema e propiciadores de impactos ao resto da economia, com exceção do índice puro de ligação para o pólo regional de Cascavel. Por apresentar o menor índice puro para frente, $12,48 \%$, este pólo, possivelmente, teria menor efeito sobre o seu sistema econômico decorrente de um crescimento da economia das outras regiões-pólo.

Tabela 6.6. Ligações puras para trás, frente e total para o sistema inter-regional, Paraná, 1995.

\begin{tabular}{|c|c|c|c|c|c|c|}
\hline \multirow{2}{*}{ Pólos Regionais } & \multicolumn{2}{|c|}{ Trás } & \multicolumn{2}{|c|}{ Frente } & \multicolumn{2}{|c|}{ Total } \\
\hline & $\%$ & Ordem & $\%$ & Ordem & $\%$ & Ordem \\
\hline Pólo Regional de Curitiba & 33,44 & 1 & 48,58 & 1 & 41,00 & 1 \\
\hline Pólo Regional de Ponta Grossa & 19,93 & 4 & 18,66 & 3 & 19,30 & 3 \\
\hline Pólo Regional de Londrina & 25,02 & 2 & 20,28 & 2 & 22,65 & 2 \\
\hline Pólo Regional de Cascavel & 21,61 & 3 & 12,48 & 4 & 17,05 & 4 \\
\hline Total & 100,00 & & 100,00 & & 100,00 & \\
\hline
\end{tabular}

Fonte: dados estimados pelo autor.

A Tabela 6.7 mostra como a produção total de um dado pólo regional é afetada pela sua própria produção e pela produção das demais regiões-pólo do sistema. 
Assim, podem-se classificar os pólos regionais de acordo com seu grau de dependência no sistema produtivo. A título de exemplo, considere o pólo regional de Curitiba. $\mathrm{O}$ valor da produção de todos os setores desta região foi de $\mathbf{R} \$ 32.831 .480$ mil, dos quais R \$30.039.673 mil (91,50\%) foram devidos à produção necessária para suprir a demanda final do próprio pólo regional e $\mathrm{R} \$ 2.791 .807 \mathrm{mil}$ (8,50\%) foram gerados pelas necessidades de produção das outras regiões-pólo do sistema. Desse modo, quanto maior a produção induzida pela demanda final do resto da economia, mais a região está integrada à economia ou, dito de outra forma, maior será o seu grau de dependência .

Os resultados da Tabela 6.7 demonstram uma estrutura econômica razoavelmente dinâmica em todos os pólos regionais, embora os de Curitiba, Londrina e Cascavel revelem uma menor dependência regional na geração de demanda para seus produtos e serviços. O pólo regional de Ponta Grossa evidenciou uma estrutura produtiva com maior grau de dependência. $10,02 \%$ da sua produção devem-se às demandas finais dos demais pólos do sistema inter-regional.

Tabela 6.7. Composição da produção dos pólos regionais, segundo indução da demanda final própria e do resto do Paraná, 1995.

\begin{tabular}{|c|c|c|c|c|c|}
\hline \multirow{3}{*}{ Pólo Regional $(j)$} & \multicolumn{4}{|c|}{ Produção induzida pela demanda final } & \multirow{3}{*}{$\begin{array}{c}\text { Produção } \\
\text { Total }\end{array}$} \\
\hline & \multicolumn{2}{|c|}{ da região $(j)$} & \multicolumn{2}{|c|}{ do resto do Paraná } & \\
\hline & Valor & $\%$ & Valor & $\%$ & \\
\hline Pólo Regiona & 30.039 .673 & 91,50 & 2.791 .807 & 8,50 & 32.8 \\
\hline Pólo Regional de Ponta Grossa & 9.607 .268 & 89,98 & 1.069 .506 & 10,02 & 10.676 .774 \\
\hline Pólo Regional de Londrina & 14.756 .104 & 92,69 & 1.163 .764 & 7,31 & 15.919 .869 \\
\hline Pólo Regional de Cascavel & 9.160 .534 & 92,76 & 714.814 & 7,24 & 9.875 .348 \\
\hline
\end{tabular}

Fonte: dados estimados pelo autor.

Os dados da Tabela 6.8 mostram a supremacia do pólo regional de Curitiba, que respondeu por $47,37 \%$ do valor da produção total do Paraná em 1995, enquanto o segundo pólo mais importante, o de Londrina, gerou $22,97 \%$ da produção paranaense. 0 restante da produção total do Paraná ficou, praticamente, dividida entre os pólos de Ponta Grossa e Cascavel com 15,41\% e 14,25\%, respectivamente. 
Tabela 6.8. Participação da produção dos pólos regionais no total do Paraná, segundo indução da demanda final própria e do resto do Paraná, 1995.

(Em Mil Reais)

\begin{tabular}{|c|c|c|c|c|c|c|}
\hline \multirow{3}{*}{ Pólo Regional (j) } & \multicolumn{4}{|c|}{ Produção induzida pela demanda final } & \multirow{2}{*}{\multicolumn{2}{|c|}{$\begin{array}{c}\text { Produção } \\
\text { Total }\end{array}$}} \\
\hline & \multirow{2}{*}{\multicolumn{2}{|c|}{$\begin{array}{c}\text { da região }(j) \\
\text { Valor (\%) Total } \\
\text { Paraná }\end{array}$}} & \multicolumn{2}{|c|}{ do resto do Paraná } & & \\
\hline & & & Valor & $\begin{array}{l}\text { (\%) Total } \\
\text { Paraná }\end{array}$ & Valor & $\%$ \\
\hline Pólo Regional de Curitiba & 30.039 .673 & 43,35 & 2.791 .807 & 4,03 & 32.831 .480 & 47,37 \\
\hline Pólo Regional de Ponta Grossa & 9.607 .268 & 13,86 & 1.069 .506 & 1,54 & 10.676 .774 & 15,41 \\
\hline Pólo Regional de Londrina & 14.756.104 & 21,29 & 1.163 .764 & 1,68 & 15.919 .869 & 22,97 \\
\hline Pólo Regional de Cascavel & 9.160 .534 & 13,22 & 714.814 & 1,03 & 9.875 .348 & 14,25 \\
\hline Total & 63.563 .580 & 91,72 & 5.739 .891 & 8,28 & 69.303 .470 & 100,00 \\
\hline
\end{tabular}

Fonte: dados estimados pelo autor.

A principal região produtora do Estado apresentou a maior participação da produção induzida pelos demais pólos regionais, $4,03 \%$, na produção estadual, enquanto a participação da segunda região mais importante foi de $1,68 \%$. O pólo regional de Ponta Grossa teve uma participação de $1,54 \%$ na produção estadual. No entanto, vale ressaltar que esta participação representou $10,02 \%$ de sua produção total. No que se refere à participação da produção induzida pela demanda final da própria região na produção estadual observou-se o mesmo comportamento da importância de cada pólo regional na produção estadual.

\subsubsection{Desagregação da interação regional}

A demanda final das regiões desencadeia efeitos diretos e indiretos, induzindo produção diferenciada dependendo da estrutura econômica intersetorial e inter-regional. A Tabela 6.9 apresenta a produção dos pólos regionais desagregada pela origem das demandas finais. Nas linhas está a produção de cada pólo regional e nas colunas o pólo do qual se originou esta produção. Como exemplo, a primeira linha mostra que o pólo regional de Curitiba apresentou $91,50 \%$ de sua produção induzidos por sua própria demanda final, 2,61\% pela demanda final do pólo regional de Ponta Grossa, 3,27\% pelo de Londrina e 2,62\% pelo de Cascavel. 
Tabela 6.9. Produção dos pólos regionais induzidas pelas demandas finais, Paraná, 1995.

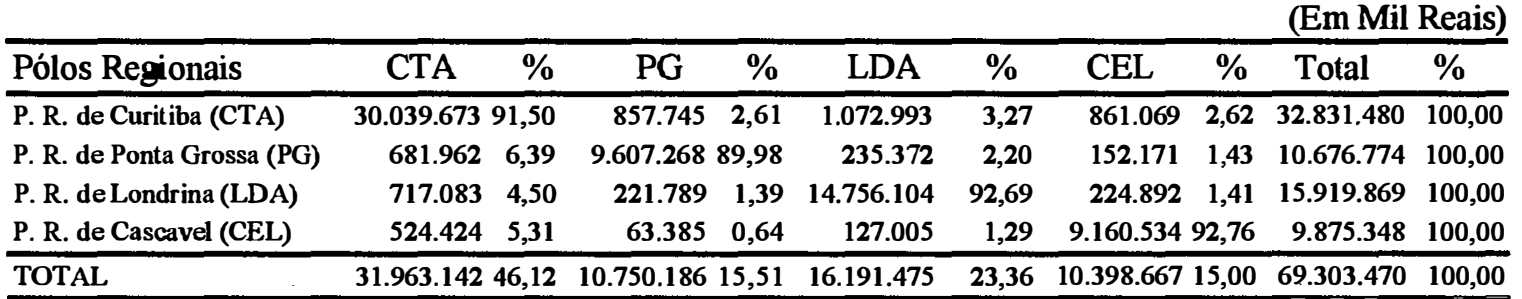

Fonte: dados estimados pelo autor.

É notória a participação do pólo regional de Curitiba nas demandas finais das outras regiões-pólo, seguido pelo de Londrina. Nota-se que a maior contribuição, 6,39\%, da demanda final do pólo de Ponta Grossa deve-se à demanda final do pólo de Curitiba, como esperado, devido à proximidade geográfica entre estas regiões e a maior concentração populacional no pólo regional de Curitiba. Concluindo, percebe-se a relevância do pólo regional de Curitiba como indutor de demanda final para os demais pólos componentes do sistema inter-regional paranaense.

\subsubsection{Desagregação setorial: impactos da demanda final própria}

A produção induzida pela demanda final de cada região-pólo pode, também, ser desagregada por setor. Desse modo, utilizando-se do exemplo anterior, pode-se determinar a participação de cada setor nos $91,50 \%$ da produção do pólo regional de Curitiba induzida pela sua própria demanda final, nos $2,61 \%$ induzidos pela demanda final de Ponta Grossa, nos 3,27\% induzidos pela de Londrina e 2,62\% induzidos pela de Cascavel.

Estas participações setoriais estão organizadas na Figura 6.17, construída incluindo os setores que apresentaram participações iguais ou superiores a $3 \%$ por convenção. Portanto, deve-se observar que estas porcentagens somadas não totalizam $100 \%$ por região. De forma geral, a distribuição da produção setorial das regiões-pólo, considerando suas próprias demandas finais, permite identificar a característica da estrutura produtiva de cada uma delas. 


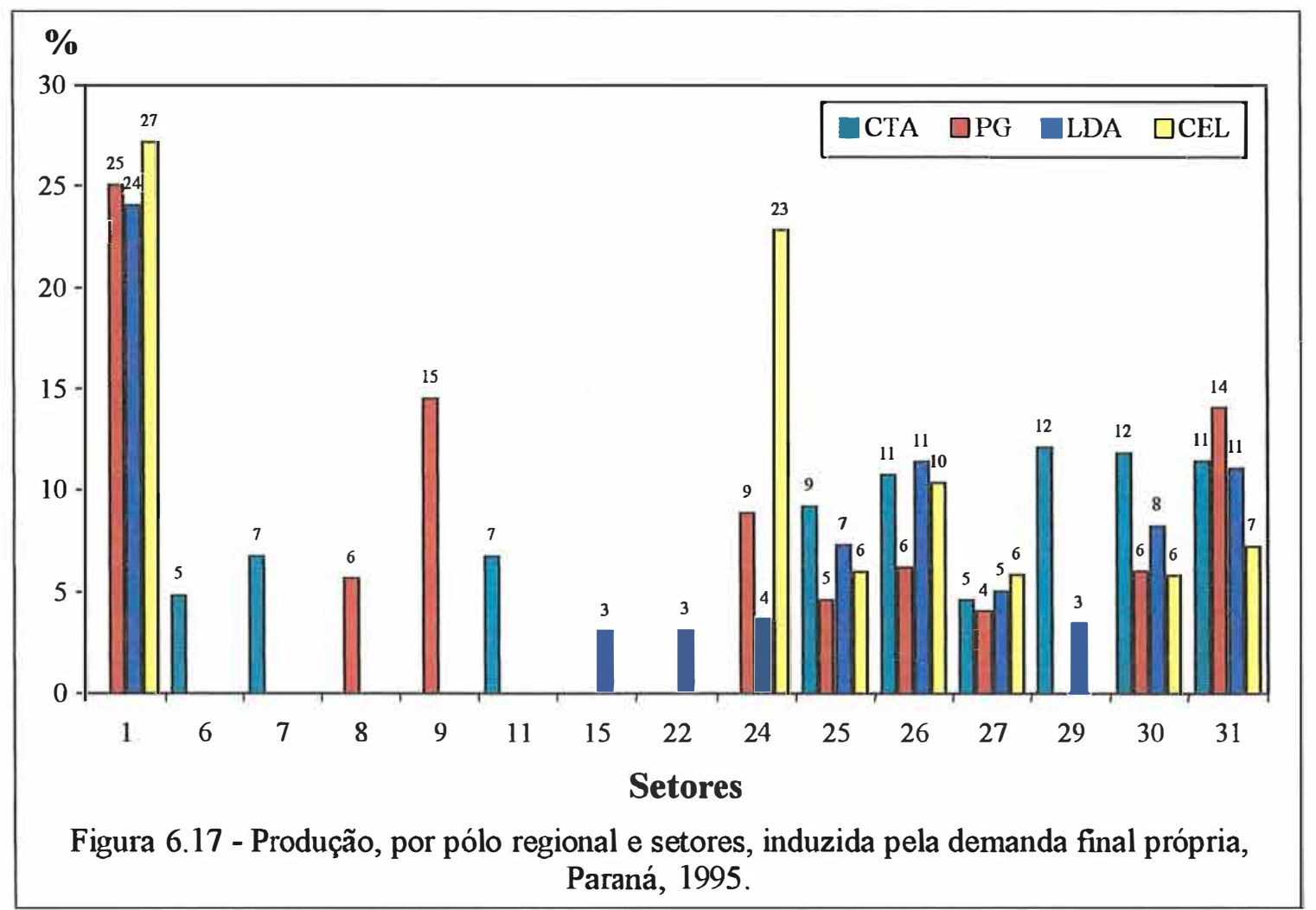

O impacto da demanda final de cada região-pólo sobre seus setores produtivos está ilustrado na Figura 6.17. A primeira barra desta figura indica que 25\% da produção do setor Agropecuária (1) do pólo regional de Ponta Grossa foi induzida pela sua própria demanda final. Por sua vez, a do setor Celulose, Papel e Gráfica (9) foi induzida em 15\%, a do setor Outros Serviços (31) em 14\%, a do setor Serviços Industriais de Utilidade Pública (24) em 9\%, e assim por diante.

Uma observação geral desta Figura permite constatar que os setores Agropecuária (1), Comércio (26) e Outros Serviços foram os que apresentaram a maior parcela da produção induzida pelas demandas finais próprias para o pólo regional de Londrina. Para o pólo regional de Cascavel, o destaque ficou para os setores Agropecuária (1), Serviços Industriais de Utilidade Pública (24) e Comércio (26) com $27 \%, 23 \%$ e $10 \%$, respectivamente, como os de maior participação na produção induzida pela sua própria demanda final. Por fim, demanda final própria do pólo regional de Curitiba induziu a produção, principalmente, dos setores vinculados ao ramo 
serviço, notadamente a dos setores Instituições Financeiras (29) e Administração Pública (30).

Resumindo, a análise precedente evidenciou a tendência dos impactos da demanda final própria concentrada nos setores vinculados ao ramo serviços para todos os pólos regionais, com exceção do setor Agropecuária (1) para as regiões tradicionalmente agrícolas no Estado, Londrina, Ponta Grossa e Cascavel.

\subsubsection{Desagregação setorial: impactos da demanda final de outras regiões}

As Figuras 6.18 a 6.21 mostram os impactos na produção de cada pólo regional, por setor, induzidos pelas demandas finais das outras regiões-pólo do sistema. Considerando a região-pólo de Curitiba, ilustrada na Figura 6.18, pode-se identificar como a parcela de sua produção induzida pelas outras regiões-pólo se distribui entre os setores de sua economia para 1995. A primeira barra desta figura indica para cada setor, respectivamente, que 6\% da demanda final da região-pólo de Ponta Grossa sobre a de Curitiba é exercida no setor Fabricação de Minerais não Metálicos (3), 5\% no setor Máquinas e Equipamentos (5), 4\% no setor Material Elétrico/Eletrônico (6), e assim por diante. Mais uma vez, é preciso atentar para o fato de que as porcentagens somadas, por região indutora, não totalizam $100 \%$, já que foram considerados os setores com valores iguais ou superiores a $3 \%$.

A Figura 6.18, evidencia nitidamente, que pouco mais de um terço das demandas finais dos outros pólos regionais induziu a produção do setor Química (11) do pólo regional de Curitiba, destacando-se o pólo de Londrina em que $39 \%$ de sua demanda total acionou a produção da Química (11) de Curitiba.

Num outro patamar, merecem destaque os setores Instituições Financeiras (29), Material de Transportes (7) e Fabricação de Minerais não Metálicos (3) que foram acionados, em média, pelas demandas finais das outras regiões-pólo com 8,3\%, 7,3\% e $6,6 \%$, respectivamente. Além destes, outros dois setores, Máquinas e Equipamentos (5) e Material Elétrico/Eletrônico (6) do pólo de Curitiba, foram acionados em cerca de 5\% pelas demandas finais das demais regiões-pólo do sistema. 


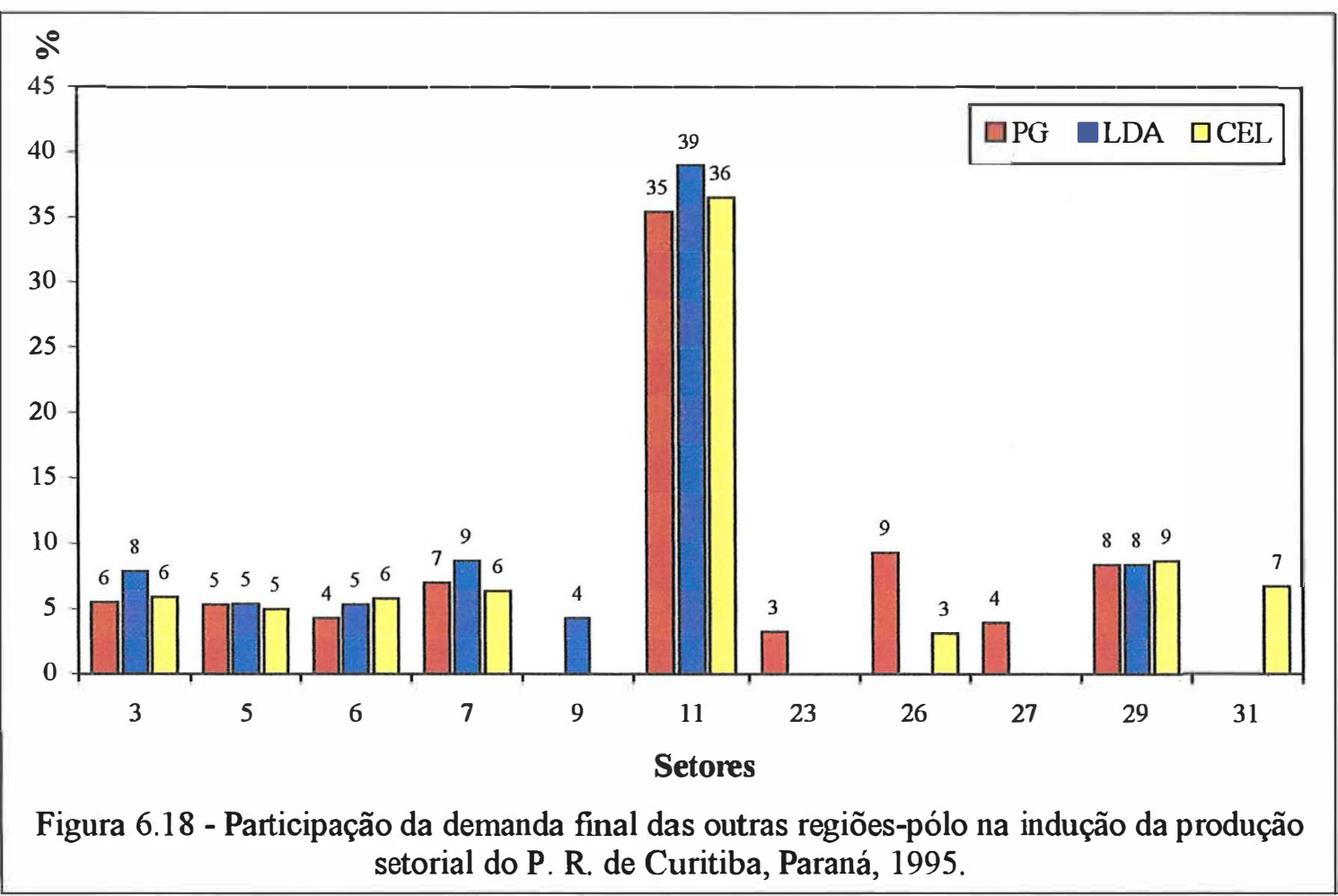

Cabe destacar a importância do pólo regional de Ponta Grossa para produção do setor Comércio (26) da região de Curitiba. Nota-se que $9 \%$ da demanda final de Ponta Grossa foi para este setor. Possivelmente, a proximidade entre as duas principais cidades, explique este fato.

Pode-se concluir, portanto, que o pólo regional de Curitiba apresentou maior integração com o pólo vizinho de Ponta Grossa, já que este, por meio de sua demanda final, acionou 9 setores da estrutura produtiva da economia da região metropolitana da capital do Estado. Por outro lado, por acionar o menor número de setores do pólo de Curitiba, a região-pólo de Londrina parece ser a menos dependente desta região. Isto, provavelmente, deve-se ao fato de a economia desta região estar mais próxima e ligada à economia paulista.

O pólo regional de Ponta Grossa apresentou 7 setores acionados pelas demandas finais de outras regiões-pólo, mas apenas 3 demandados por todas as regiões (Figura 6.19). O destaque foi para o setor Celulose, Papel e Gráfica (9), o mais 
importante na composição da demanda final da região-pólo de Londrina, com 56\%, seguido pelos pólos de Cascavel e de Curitiba com 44\% e 35\%, respectivamente.

Na segunda colocação está o setor Serviços Industriais de Utilidade Pública (24). Sobressaem os pólos regionais de Londrina e Curitiba com $20 \%$ e $18 \%$, respectivamente, de suas demandas finais para com o pólo regional de Ponta Grossa. Vale ressaltar a importância da demanda final do pólo de Curitiba sobre a produção do setor Agropecuária (1) desta região-pólo.

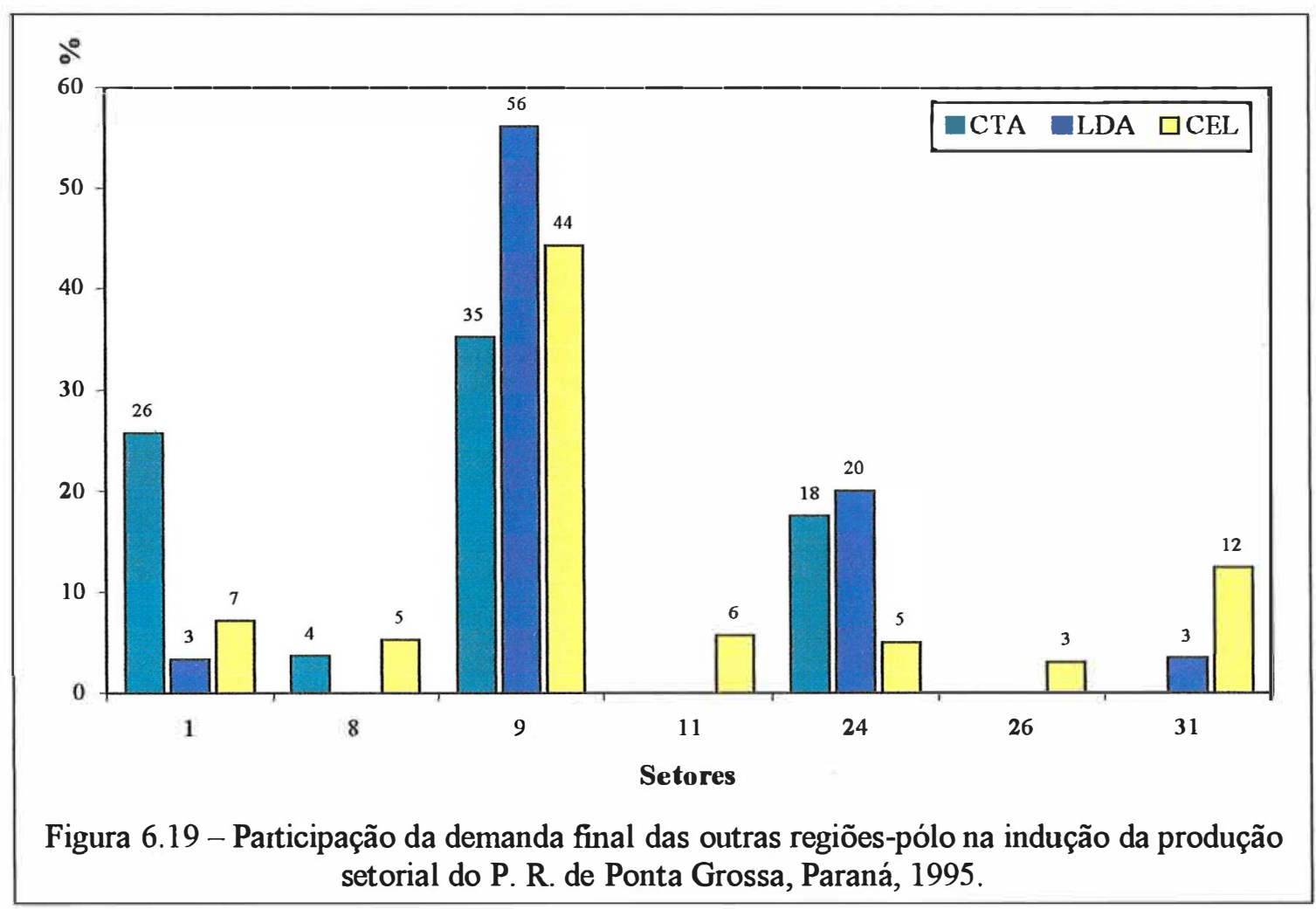

A região-pólo de Cascavel foi a mais importante demandante do pólo de Ponta Grossa, acionando 7 setores da sua estrutura produtiva. Isto indica uma integração maior entre estas duas regiões ou, em outras palavras, parte importante da produção dos setores Agropecuária (1), Madeira e Mobiliário (8), Celulose, Papel e Gráfica (9), Química (11), Serviços Industriais de Utilidade Pública (24), Comércio (26) e Outros Serviços (31) de Ponta Grossa depende da demanda final do pólo de Cascavel. 
Em síntese, pode-se afirmar que a região de Ponta Grossa apresentou baixo grau de integração com as demais regiões que compõem o sistema inter-regional paranaense, já que somente os setores considerados chaves, pelas análises anteriores, foram mais fortemente acionados pelas demandas de todas as regiões.

O pólo regional de Londrina foi o que apresentou a estrutura produtiva mais diversificada dentre as regiões-pólo da economia paranaense, com 13 setores sendo demandados por todas as outras regiões (Figura 6.20).

Pode-se verificar que, dos 13 setores mais demandados, 5 foram acionados, simultaneamente, por todas as outras regiões do sistema, principalmente a Agropecuária (1) que, foi responsável, em média, por $27,6 \%$ das demandas finais das outras regiõespólo sobre a produção da região de Londrina.

Embora o setor Química (11) não se tenha apresentado como um dos principais setores-chave da estrutura produtiva londrinense, ele foi o segundo mais induzido pelas demandas finais das outras regiões, notadamente a de Cascavel. $\mathbf{O}$ setor Industria Têxtil (14), considerado chave nesta região, respondeu por cerca de $9 \%$ das demandas finais das outras regiões-pólo. O Comércio (26) foi outro setor que se relacionou com as outras regiões, sobressaindo-se o pólo de Ponta Grossa com 17\% de sua demanda final.

Conclui-se, portanto, que o pólo regional de Londrina encontra-se mais relacionado com os pólos regionais de Curitiba e Ponta Grossa, já que a demanda final destas regiões afetaram a produção de 12 setores da estrutura produtiva de Londrina. Pode-se afirmar que a região de Londrina se integra mais a estas economias e menos intensamente à economia da região de Cascavel.

Finalmente, o pólo regional de Cascavel apresentou-se bastante diferenciado em relação às demais regiões-pólo do sistema (Figura 6.21). O setor Serviços Industriais de Utilidade Pública (24), por ser um dos principais setores-chave desta região, foi o único induzido pelas demandas finais das outras regiões. $\mathrm{O}$ pólo regional de Londrina foi o principal indutor da produção desse setor com $78 \%$ da sua demanda final, seguido pelo pólo de Curitiba com $49 \%$. Cabe salientar que este foi o único setor da região de Cascavel afetado pelas demandas finais de Londrina. 


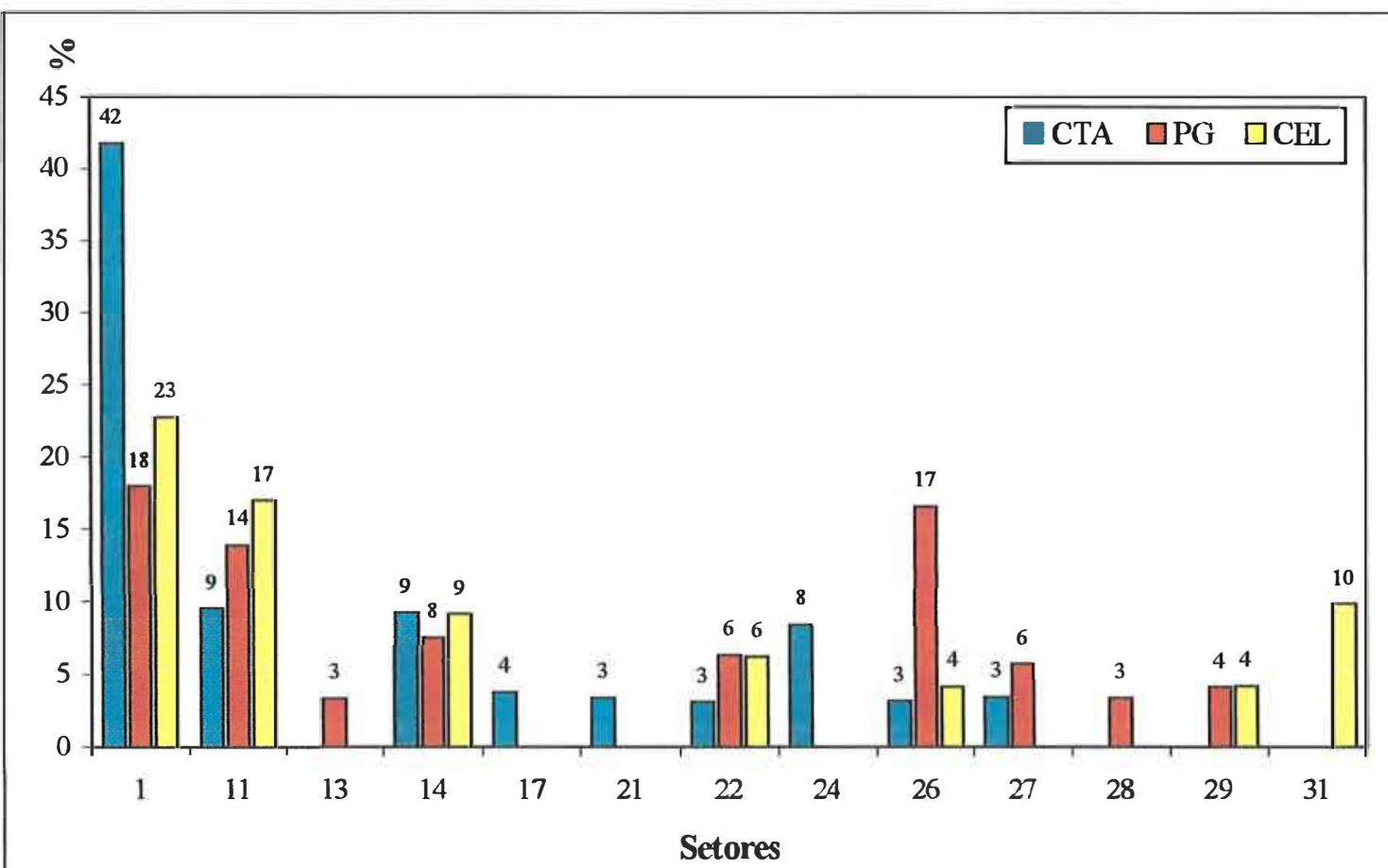

Figura 6.20 - Participação da demanda final das outras regiões-pólo na indução da produção setorial do P. R. de Londrina, Paraná, 1995.

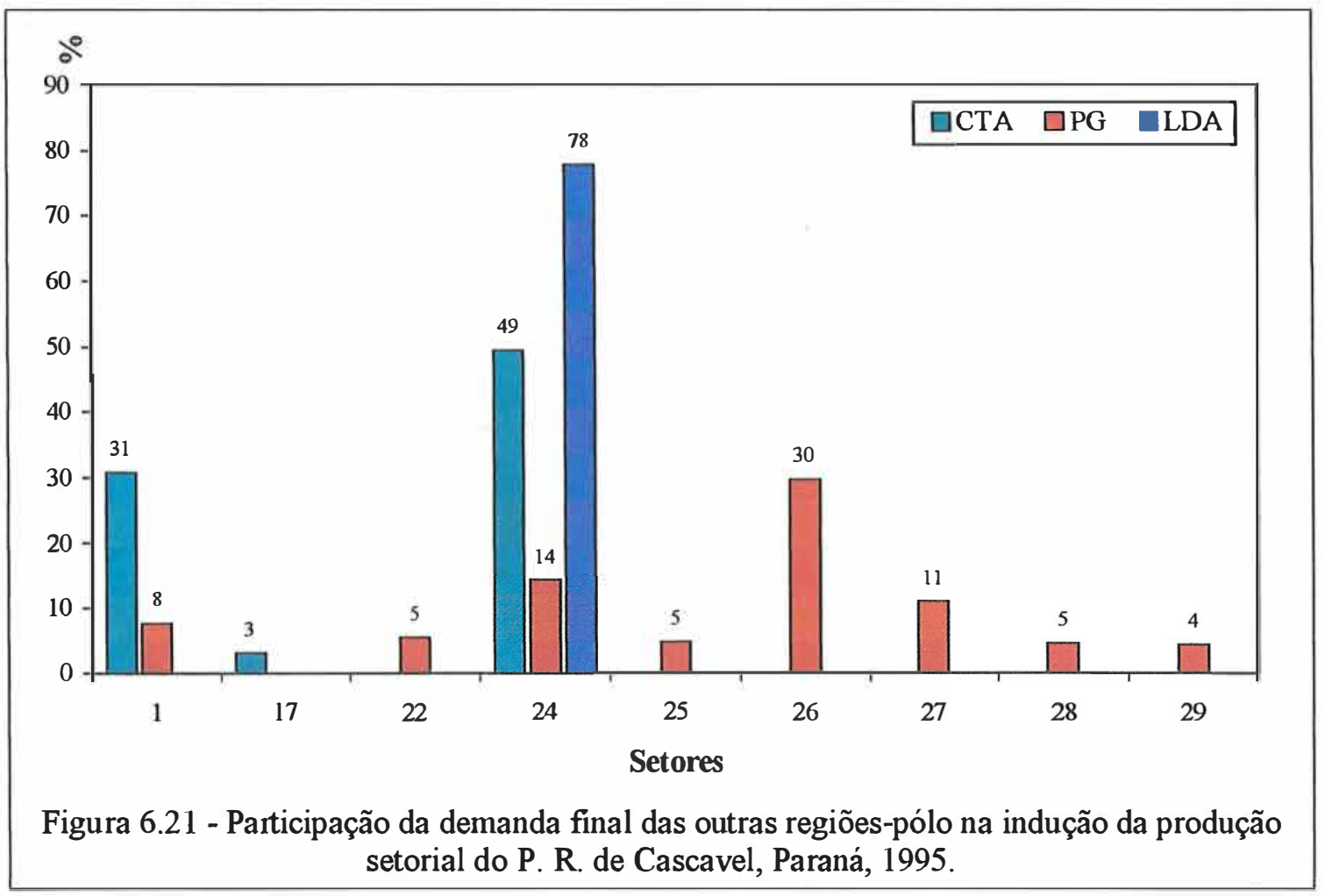


A região de Cascavel mostrou-se mais dependente do pólo regional de Ponta Grossa. Dos 9 setores acionados pelas demandas finais de todas as regiões, 8 foram induzidos pela demanda final de Ponta Grossa, sendo a maioria deles vinculados ao ramo serviços, com destaque para o setor Comércio (26).

A análise desenvolvida nesta seção permitiu constatar algumas características importantes entre as regiões-pólo da economia paranaense: a) os pólos regionais de Curitiba e de Londrina apresentaram suas estruturas produtivas diversificadas, com maior número de setores-chave para a dinâmica da economia paranaense, confirmando as constatações feitas pelos índices de ligações; b) as estruturas produtivas dos pólos regionais de Ponta Grossa e Cascavel revelaram-se menos diversificas e integradas à economia paranaense e c) a produção interna das regiões de Ponta Grossa e de Cascavel foram induzidas com maior intensidade pelas demandas finais destas regiões e, em menor grau, pelas de outras regiões.

\subsection{Interações sinergéticas entre as regiões-pólo}

A metodologia descrita na seção 5.3 do capítulo 5 foi aplicada para o sistema inter-regional construído para o Estado do Paraná, possibilitando analisar e mensurar as transações entre os 4 pólos regionais. Desse modo, é possível verificar quanto as relações de produção em uma dada região influenciam a produção de outra região.

Analisando a Tabela 6.10, pode-se verificar que a contribuição da primeira rodada, em que cada matriz é tratada isoladamente, representou mais de $84 \%$ da produção interna de cada pólo regional, notadamente o de Curitiba que atingiu $88,53 \%$. É importante lembrar que, nesta primeira rodada, não existe sinergia entre os pólos, o que ocorre somente a partir da segunda. Assim, com esta, os pólos de Ponta Grossa e de Cascavel foram os que apresentaram os maiores acréscimos na produção, 12,34\% e $10,13 \%$, respectivamente. A quinta combinação dos blocos de matrizes gerou $99,99 \%$ de explicação da produção para todos os pólos regionais, de forma que as demais combinações explicam apenas $0,01 \%$. 
Tabela 6.10. Contribuição (\%) das combinações $1,2,3,4$ e 5 dos blocos de matrizes para a produção em cada região-pólo, Paraná, 1995.

\begin{tabular}{ccccc}
\hline $\begin{array}{c}\text { Número de } \\
\text { matrizes }\end{array}$ & $\begin{array}{c}\text { Pólo Regional } \\
\text { de Curitiba }\end{array}$ & $\begin{array}{c}\text { Pólo Regional } \\
\text { de Ponta Grossa }\end{array}$ & $\begin{array}{c}\text { Pólo Regional } \\
\text { Londrina }\end{array}$ & $\begin{array}{c}\text { Pólo Regional } \\
\text { de Cascavel }\end{array}$ \\
\hline 1 & 88,53 & 84,39 & 87,70 & 87,75 \\
2 & 7,98 & 12,34 & 9,88 & 10,13 \\
3 & 3,07 & 2,88 & 2,21 & 1,94 \\
4 & 0,37 & 0,32 & 0,15 & 0,11 \\
5 & 0,04 & 0,07 & 0,06 & 0,06 \\
Resíduo & 0,01 & 0,01 & 0,01 & 0,01 \\
\hline Total & 100,00 & 100,00 & 100,00 & 100,00 \\
\hline
\end{tabular}

Fonte: dados estimados pelo autor.

A Tabela 6.11 e as Figuras 6.22 a 6.25 mostram as relações sinergéticas entre as regiões-pólo. Para o pólo regional de Curitiba observou-se que as 6 relações principais (maiores que $1 \%$ ) responderam por mais de $98,18 \%$ da produção. Os pólos regionais de Ponta Grossa e Londrina, apresentaram 97,90\% da produção induzidas pelas 5 e 6 maiores relações, respectivamente, enquanto $98,29 \%$ da produção do pólo regional de Cascavel ocorreram com 5 relações.

Tomando-se inicialmente o pólo regional de Curitiba, observa-se que as relações internas do processo produtivo foram responsáveis por $73,77 \%$ da produção total dessa região-pólo (Figura 6.22 ). Ademais, $7,95 \%$ da sua produção total devem-se às transações comerciais com o pólo regional de Ponta Grossa. Em outras palavras, as vendas de insumos que este pólo faz para o de Ponta Grossa contribuem com 7,95\% da sua produção total. Ainda, de acordo com este raciocínio, as vendas de insumos para os pólos regionais de Londrina e de Cascavel geram, respectivamente, 7,69\% e 6,23\% da produção total de Curitiba. Assim, as vendas de insumos que esta região-pólo realiza para todos os outros pólos do sistema representam $21,87 \%$ de sua produção total. Vale notar, ainda, que as relações de produção dentro dos pólos regionais de Ponta Grossa e de Londrina impactaram, respectivamente, $1,13 \%$ e 1,41\% da produção do pólo regional de Curitiba. Por outro lado, as compras de insumos que o pólo regional de Curitiba realiza das outras regiões-pólo geram apenas $0,54 \%$ da sua produção total. 
O resultado dessas interações revelam que o pólo regional de Curitiba é mais dependente do processo produtivo dos demais pólos regionais do sistema inter-regional e, também, o mais integrado à economia paranaense.

Tabela 6.11. Contribuição (\%) de cada matriz para a participação total de $\left(y_{1}-f\right)$ em $y$ para as regiões-pólo, Paraná, 1995.

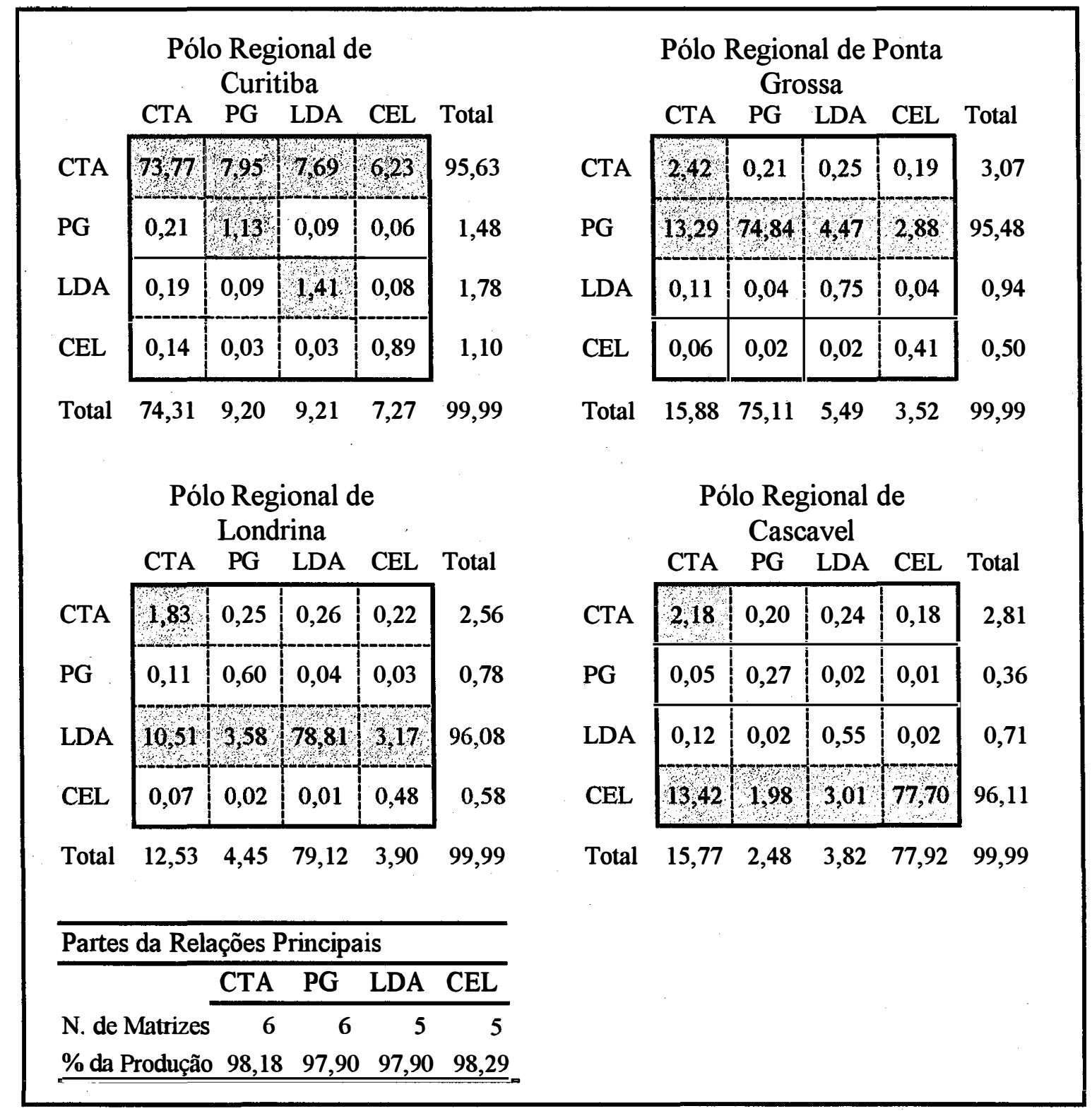

Fonte: dados estimados pelo autor. 


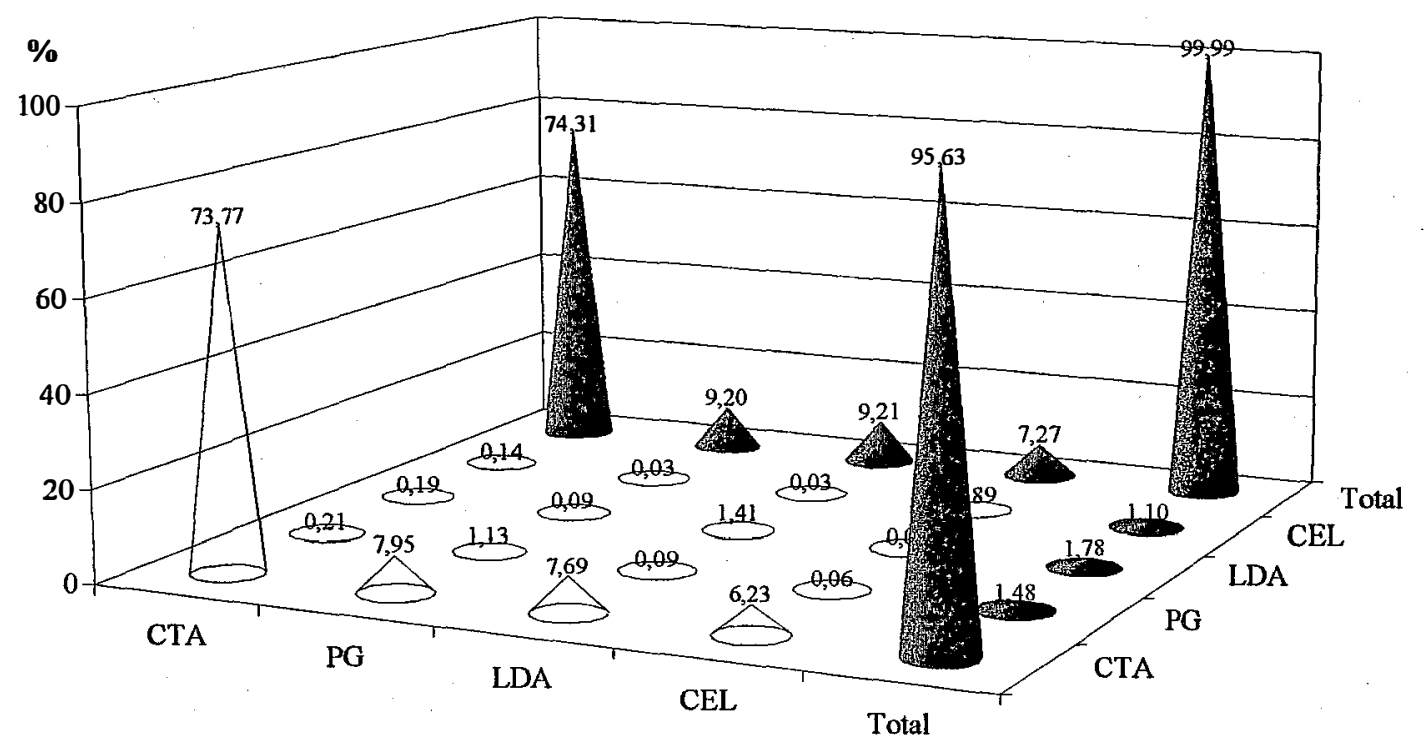

Figura 6.22 - Pólo Regional de Curitiba: contribuição (\%) de cada matriz para a participação total de $\left(y_{1}-f\right)$ em $y$ para as regiões-pólo, Paraná, 1995.

Analisando o pólo regional de Ponta Grossa, verifica-se que $74,84 \%$ da sua produção são devidos às vendas de insumos realizadas dentro da própria região. Nota-se a existência de uma forte relação com o pólo regional de Curitiba, considerando-se que $13,29 \%$ da sua produção total são decorrentes de vendas de insumos para esta região. A compra de insumos pelos pólos regionais de Londrina e de Cascavel geram 4,47\% e $2,88 \%$, respectivamente, da produção total do pólo de Ponta Grossa. As relações internas de produção da região de Curitiba representaram 2,42\% da produção do pólo regional de Ponta Grossa, enquanto as relações de produção internas das regiões de Londrina e Cascavel, praticamente, tiveram pouco efeito sobre o processo produtivo do pólo regional de Ponta Grossa (Figura 6.23).

Em geral, este pólo regional apresenta-se integrado e dependente do resto da economia paranaense, tendo em vista que $20,64 \%$ da sua produção total dependem das vendas de insumos às demais regiões-pólo do sistema.

Os resultados para o pólo regional de Londrina evidenciam uma estrutura produtiva mais fechada em relação às demais regiões-pólo, uma vez que as relações internas do processo produtivo responderam por $78,81 \%$ da produção total, o que 
caracteriza menor dependência das outras regiões do sistema. Este pólo apresenta, também, uma forte ligação com o de Curitiba, uma vez que as vendas de insumos a este foram responsáveis por $10,51 \%$ da sua produção (Figura 6.24). As vendas do pólo regional de Londrina para os pólos regionais de Ponta Grossa e de Cascavel representaram, respectivamente, $3,58 \%$ e $3,17 \%$ da sua produção. É importante mencionar a importância das relações internas do processo produtivo do pólo regional de Curitiba, que foram responsáveis por $1,83 \%$ da produção total do pólo regional de Londrina.

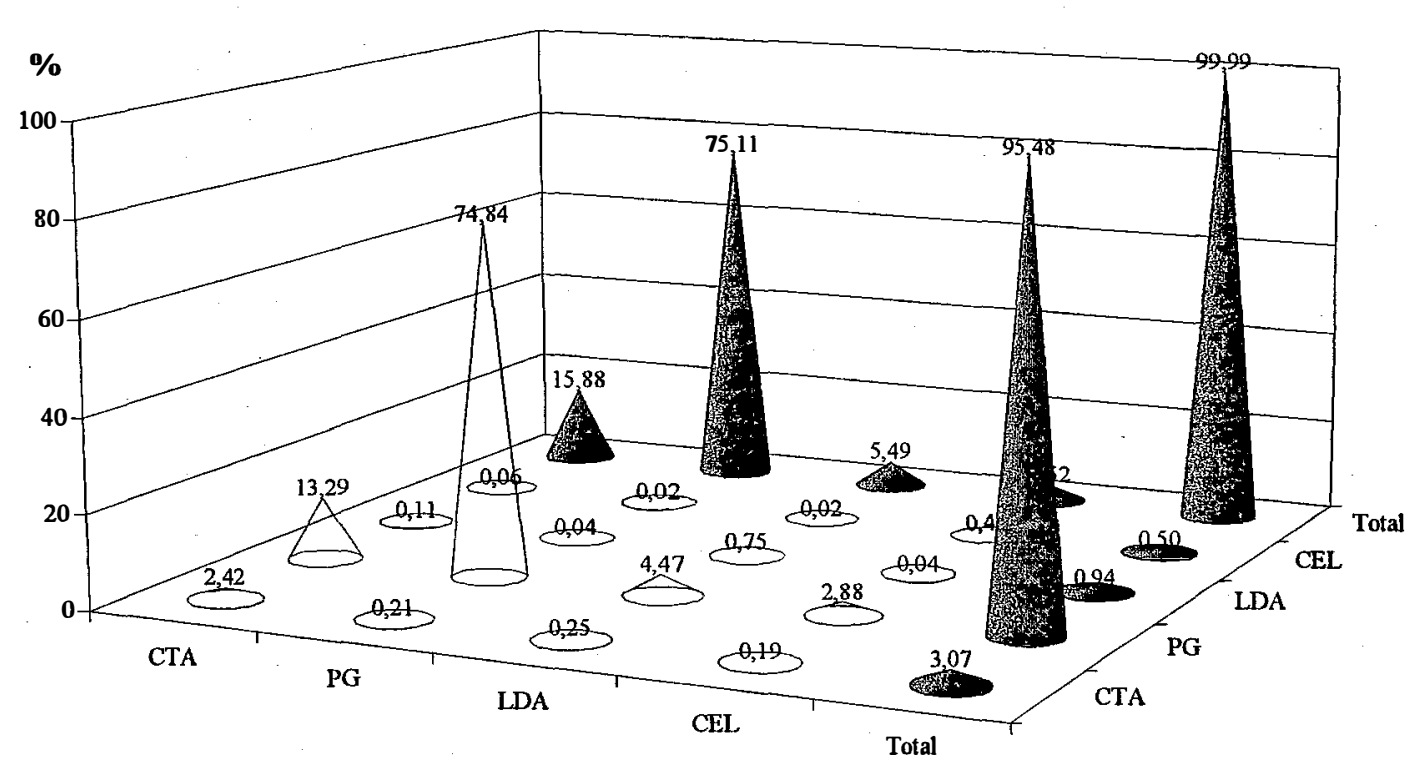

Figura 6.23 - Pólo Regional de Ponta Grossa: contribuição (\%) de cada matriz para a participação total de $(y-f)$ em $y$ para as regiões-pólo, Paraná, 1995.

Por último, a Figura 6.25 mostra que o pólo regional de Cascavel é o segundo menos dependente das outras regiões do sistema, dado que as relações internas de sua estrutura produtiva representaram $77,70 \%$ da produção no processo produtivo. Apesar disso, o pólo regional de Curitiba apresentou-se como mais importante para o processo produtivo da região de Cascavel, dado que $13,42 \%$ da sua produção total foram decorrentes das vendas de insumos àquela região. As vendas para o pólo de Londrina representaram $3,01 \%$ da sua produção enquanto somente $1,98 \%$ foram decorrentes das 
vendas ao pólo regional de Ponta Grossa, evidenciando baixa relação com esta região. As relações internas do processo produtivo da região de Curitiba representaram 2,18\% da produção da região de Cascavel.

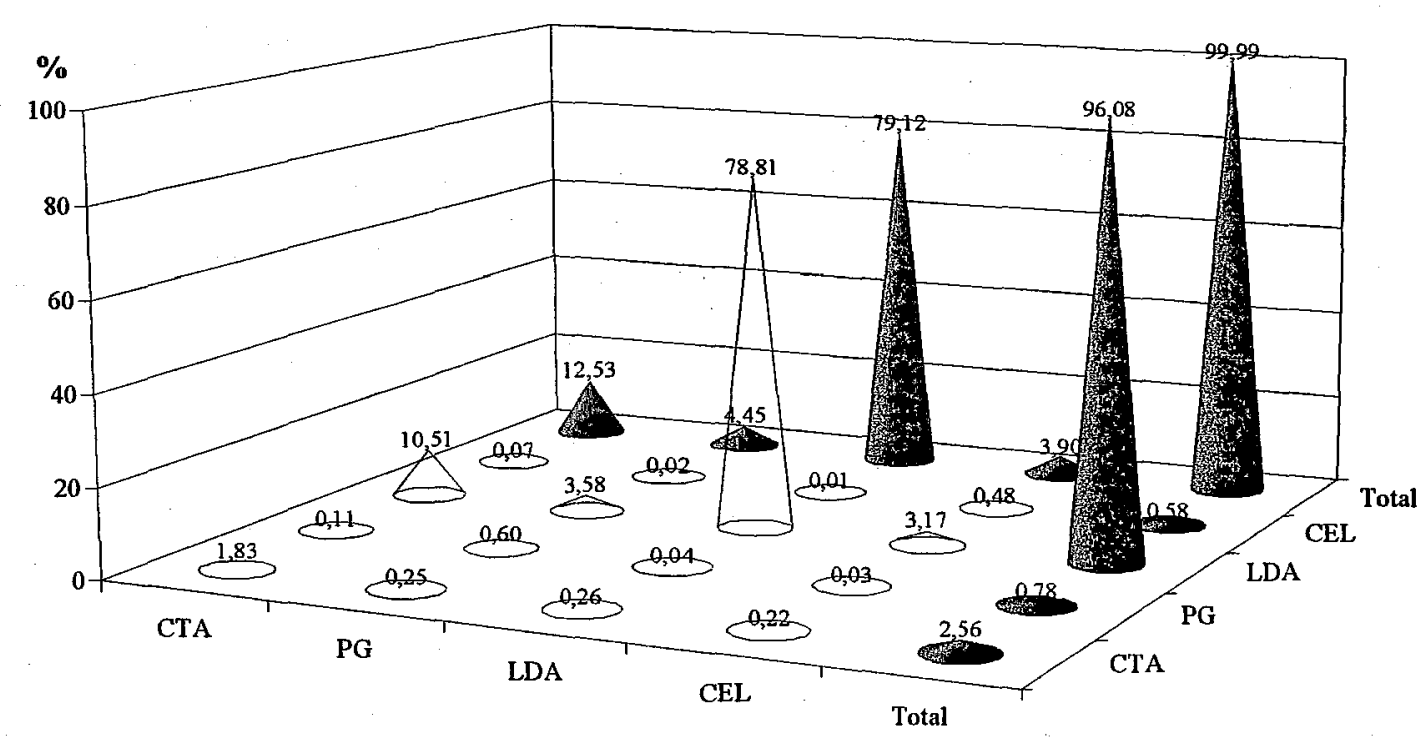

Figura 6.24 - Pólo Regional de Londrina: contribuição (\%) de cada matriz para a participação total de $(y-f)$ em $y$ para as regiões-pólo, Paraná, 1995.

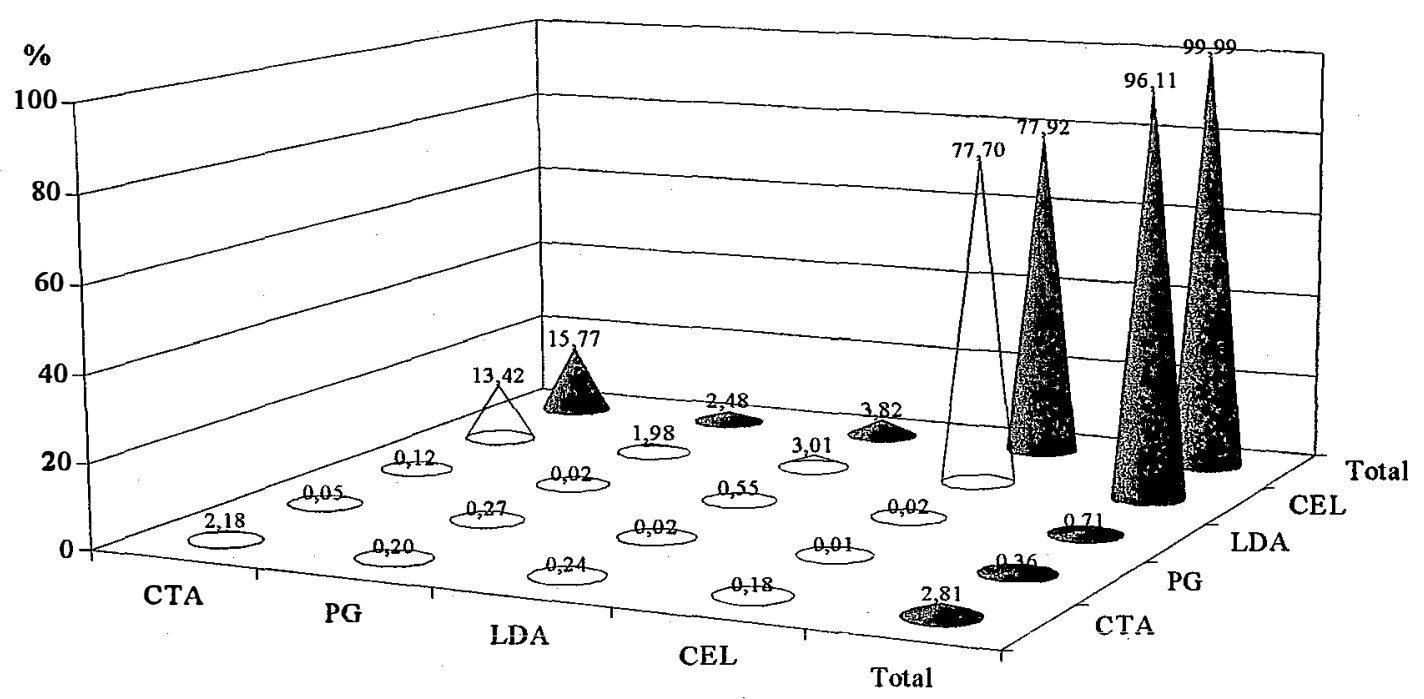

Figura 6.25 - Pólo Regional de Cascavel: contribuição (\%) de cada matriz para a participação total de $\left(y_{1}-f\right)$ em $y$ para as regiões-pólo, Paraná, 1995. 
Um exame das relações entre os pólos regionais no processo produtivo permite verificar que: a) o pólo regional de Curitiba apresentou fortes relações com os demais pólos componentes do sistema inter-regional; b) a demanda por insumos dos pólos regionais de Ponta Grossa, Londrina e Cascavel proporciona impactos significativos na estrutura produtiva do pólo regional de Curitiba; c) o pólo regional de Curitiba proporciona impacto significativo na produção dos pólos regionais de Ponta Grossa, Londrina e Cascavel e, finalmente, d) os pólos regionais de Curitiba e de Ponta Grossa apresentam estruturas produtivas mais abertas e integradas à economia paranaense do que os pólos regionais de Londrina e Cascavel. 


\section{CONCLUSÕES}

A aplicação de modelos de insumo-produto tem-se revelado num eficiente instrumental analítico, possibilitando entender melhor as relações intersetoriais estabelecidas dentro de um sistema econômico. Este instrumental revela que os processos de interdependência transacional entre diferentes economias podem ser tratados de forma sistêmica em termos de insumos e produtos. Portanto, a análise de insumo-produto descreve a economia em termos de fluxos e considera, ainda, os produtos como insumo na medida em que estes sejam utilizados por outro sistema em cadeia.

Este arcabouço teórico possibilita, também, aos órgãos executores de políticas de incentivos ao desenvolvimento de determinados setores da economia ou de regiões, na medida em que permite mensurar os efeitos de encadeamento intersetorial, propiciando, desta forma, o melhor direcionamento dos objetivos a serem atingidos por meio de políticas desenvolvementistas.

A análise das ligações industriais e a identificação dos setores-chave, a partir das técnicas de Rasmussen e Hirschman para o sistema inter-regional parananense, evidencia dois padrões diferenciados. $\mathrm{O}$ primeiro indica as regiões-pólo de Curitiba e de Londrina com ligações industriais fortes, refletidas por uma estrutura industrial melhor articulada enquanto, o segundo apresenta ligações fracas para os pólos regionais de Ponta Grossa e de Cascavel, onde estes ainda buscam implementar e consolidar suas estruturas industriais.

As ligações industriais, via critério restrito, caracteriza a indústria de Celulose, Papel e Gráfica como o principal setor-chave para a estrutura produtiva paranaense, uma vez que este setor se apresenta como chave para o agregado da 
economia e para os pólos regionais de Curitiba e Ponta Grossa. Além deste setor, as ligações industriais indicam como setor-chave a Indústria Têxtil para o agregado da economia paranaense e para o pólo regional de Londrina e os setores Fabricação de Minerais não Metálicos e Materiais de Transportes para o pólo regional de Curitiba. Cabe ressaltar a inexistência de setor-chave na estrutura produtiva da economia do pólo regional de Cascavel.

Considerando-se o critério menos restrito, as ligações industriais indicam que o agregado da economia paranaense e as regiões-pólo de Curitiba e Londrina apresentam suas estruturas econômicas mais diversificadas e integradas, centrada, basicamente, na indústria de transformação, notadamente aquelas que integram o segmento alimentar, como demandante de insumos. O setor Fabricação de Óleos Vegetais revela-se como o principal demandante de insumos na estrutura produtiva paranaense por apresentar o maior índice de encadeamento para trás. Com relação às ligações para frente, o setor Química, para o pólo regional de Curitiba e a Agropecuária para as demais regiões-pólo e o conjunto do Estado destacam-se como os principais ofertantes dentro da economia paranaense.

Estes resultados sugerem que estes setores seriam os mais indicados para se implementar políticas de desenvolvimento industrial e regional, possibilitando, dessa forma, um crescimento rápido da produção, renda e emprego na estrutura econômica paranaense.

Embora os índices de ligações de Rasmussen e Hirschman indicam os setores que mais dinamizam a economia paranaense, vale ressaltar, que esses índices não mostram os elos que processam as ligações intersetoriais mais relevantes, isto é, não especificam a importância das ligações intersetoriais derivada predominantes das transações entre os pólos regionais ou das transações entre as indústrias de cada regiãopólo. No entanto, os coeficientes com maior campo de influência no sistema interregional paranaense mostram, com clareza, os principais elos de ligações entre setores e regiões. Assim, os resultados obtidos por este enfoque confirmam a importância dos setores-chave encontrados pelos índices de Rasmussen e Hirschman para o agregado da economia paranaense. 
Os coeficientes com maior campo de influência para o sistema inter-regional revelam que os principais elos de ligações são dominados, em sua maior parte, por setores diretamente vinculados à economia dos pólos regionais de Curitiba e Ponta Grossa. Para o pólo regional de Londrina, um constatação importante é que o setor Agropecuária dinamiza todos os setores das demais regiões do sistema. Resumindo, os coeficientes com maior campo de influência indicam as possibilidades de ampliação da interdependência industrial intra e inter-regiões, via políticas de incentivos, notadamente naqueles setores com maior poder de encadeamento na estrutura produtiva paranaense.

As ligações interindustriais, medidas pelos índices puros e em termos de valor da produção, denotam nitidamente uma concentração de setores-chave ligados ao ramo serviços para a estrutura produtiva paranaense. Para o agregado do Paraná, os setores com altos índices para frente, os mais demandados e os que sofrem os maiores impactos puros da produção total do resto da economia, são os setores Química, Outros Serviços e Agropecuária. Por outro lado, os setores Administração Pública, Comércio, Agropecuária e Construção Civil são os que propiciam maiores impactos sobre o resto da economia, uma vez que são os principais demandantes dentro da economia.

Os resultados dos índices puros de ligações para frente e para trás para o sistema inter-regional revelam que a importância de cada pólo regional para a economia paranaense é bastante diferenciada e comprova a supremacia da região-pólo de Curitiba. Isto assevera que o perfil de uma maior reciprocidade ou integração econômica na economia paranaense será estabelecido por esta região, cabendo à região de Londrina o papel de segunda indutora do sistema.

Em termos setoriais, os setores que apresentam as maiores ligações puras para frente estão ligados às economias dos pólos regionais de Curitiba e de Londrina, principalmente Química, Outros Serviços e Comércio no primeiro e Agropecuária no segundo. Com relação às ligações puras para trás, novamente, os setores com os maiores índices concentram-se nas regiões-pólo de Curitiba e de Londrina, merecendo destaque os setores Administração Pública, Construção Civil, Comércio e Instituições Financeiras para a região de Curitiba e Agropecuária, Comércio, Administração Pública e Construção Civil para Londrina. 
Em síntese, as ligações intersetoriais fortes e os setores-chave de alcance inter-regional indicam que as regiões-pólo de Curitiba e de Londrina, por apresentarem melhor articulação de suas estruturas econômicas, possuem maior poder de encadeamento inter-regional para impulsionar o crescimento econômico e gerar maior interdependência comercial na economia paranaense.

A análise da produção total de cada pólo regional, afetada pela produção interna e pela produção das outras regiões do sistema, mostra uma menor dependência dos pólos regionais de Curitiba, Londrina e Cascavel na geração de demanda para seus produtos e serviços, enquanto a produção da região de Ponta Grossa apresenta um grau maior de dependência das demandas finais das demais regiões-pólo do sistema interregional, notadamente de Curitiba. Concluindo, percebe-se, claramente, a relevância do pólo regional de Curitiba como indutor de demanda final para todas as regiões da economia paranaense.

O impacto sobre a demanda final própria de cada região-pólo, desagregada por setor, concentra-se, basicamente, nos setores vinculados ao ramo serviços para todas as regiões-pólo, exceto para o setor Agropecuária nas regiões tradicionalmente agrícolas do Estado, Londrina, Ponta Grossa e Cascavel.

A mensuração do impacto sobre a produção setorial de cada pólo regional, induzida pela demanda final das outras regiões, revela que a produção de 11 setores do pólo regional de Curitiba é induzida pela demanda final das outras regiões componentes do sistema inter-regional, principalmente a do setor Química. Além disso, verifica-se uma integração forte com a região vizinha de Ponta Grossa, tendo em vista que a demanda desta região-pólo afeta a produção de 9 setores da estrutura produtiva do pólo regional de Curitiba.

Ainda nesta linha de análise, o pólo regional de Londrina apresenta a estrutura produtiva mais diversificada dentre as regiões-pólo da economia paranaense, já que a demanda final dos demais pólos afetam a produção de 13 setores da sua economia, principalmente a do setor Agropecuária.

Com relação aos pólos regionais de Ponta Grossa e de Cascavel, constata-se que suas estruturas produtivas são menos diversificadas e integrados à economia 
paranaense. Apesar disso, nota-se uma integração entre essas duas regiões, uma vez que a demanda final da região de Cascavel afeta a produção de 7 setores da economia da região de Ponta Grossa, notadamenta a do setor Celulose, Papel e Gráfica. Por outro lado, a demanda final da região de Ponta Grossa induz a produção de 8 setores da estrutura econômica da região de Cascavel, principalmente a do Comércio.

A análise comparativa da estrutura econômica de cada pólo regional com a do Paraná, derivada das matrizes de intensidade, mostra que as economias de Londrina, Ponta Grossa e Cascavel são semelhantes e apresentam características similares à estrutura da economia paranaense, enquanto o pólo regional de Curitiba apresenta a estrutura produtiva mais interligada e diferenciada em relação à do Paraná.

Os resultados da interação sinergética entre os pólos regionais mostram que o pólo regional de Curitiba é o mais dependente dos processos produtivos das outras regiões do sistema. As relações internas da região-pólo de Londrina, a segunda mais importante, evidenciam uma estrutura produtiva mais fechada, isto é, menos dependente em relação às outras regiões do sistema. Os pólos regionais de Ponta Grossa e de Cascavel apresentam as maiores relações com o pólo regional de Curitiba indicando uma integração relativamente forte entre essas regiões.

Finalmente, cabe ressaltar que o sistema inter-regional que utiliza o instrumental insumo-produto requer um grande número de informações, o que permite um detalhamento maior da análise em estudos desta natureza. Embora, o nível de desagregação utilizado nesta pesquisa não tenha sido o desejado, em função da dificuldade de obtenção e mesmo da ausência de informações mais precisas, os resultados encontrados constituem uma fonte de reflexão e uma primeira tentativa de mensurar as relações interindustriais para as principais regiões produtoras do Paraná. Além disso, os resultados do trabalho identificam os segmentos produtivos da economia paranaense passíveis de ações de políticas de incentivos.

É oportuno, pois, registrar a necessidade de se construir um banco de dados que contenha os fluxos de comércio inter-regionais, o que permitiria construir um sistema inter-regional com um nivel de desagregação setorial maior, possibilitando a obtenção de resultados mais satisfatórios em estudos futuros. 


\section{ANEXOS}

Anexo A - Matriz de insumo-produto do sistema inter-regional, Paraná, 1995. 


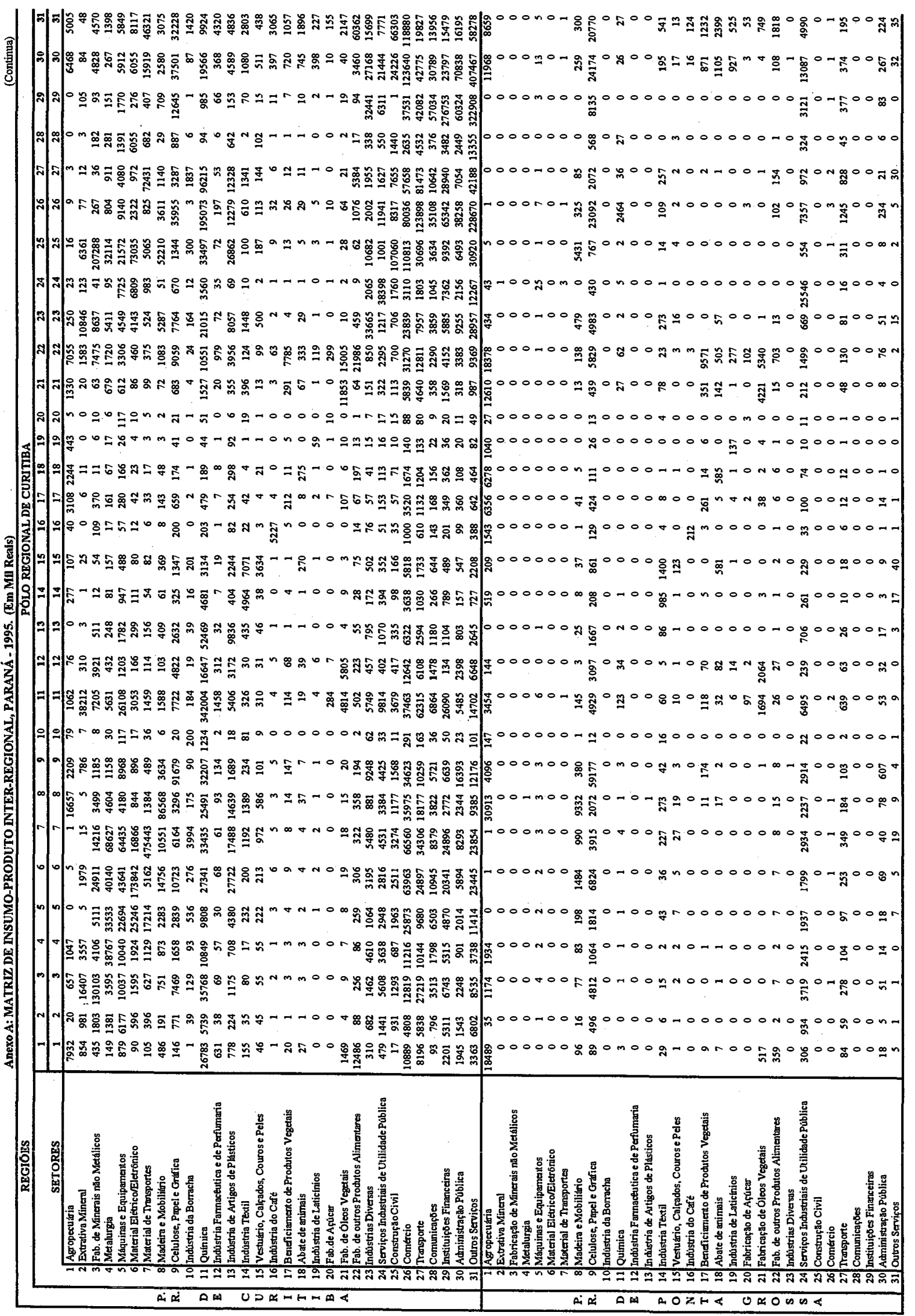




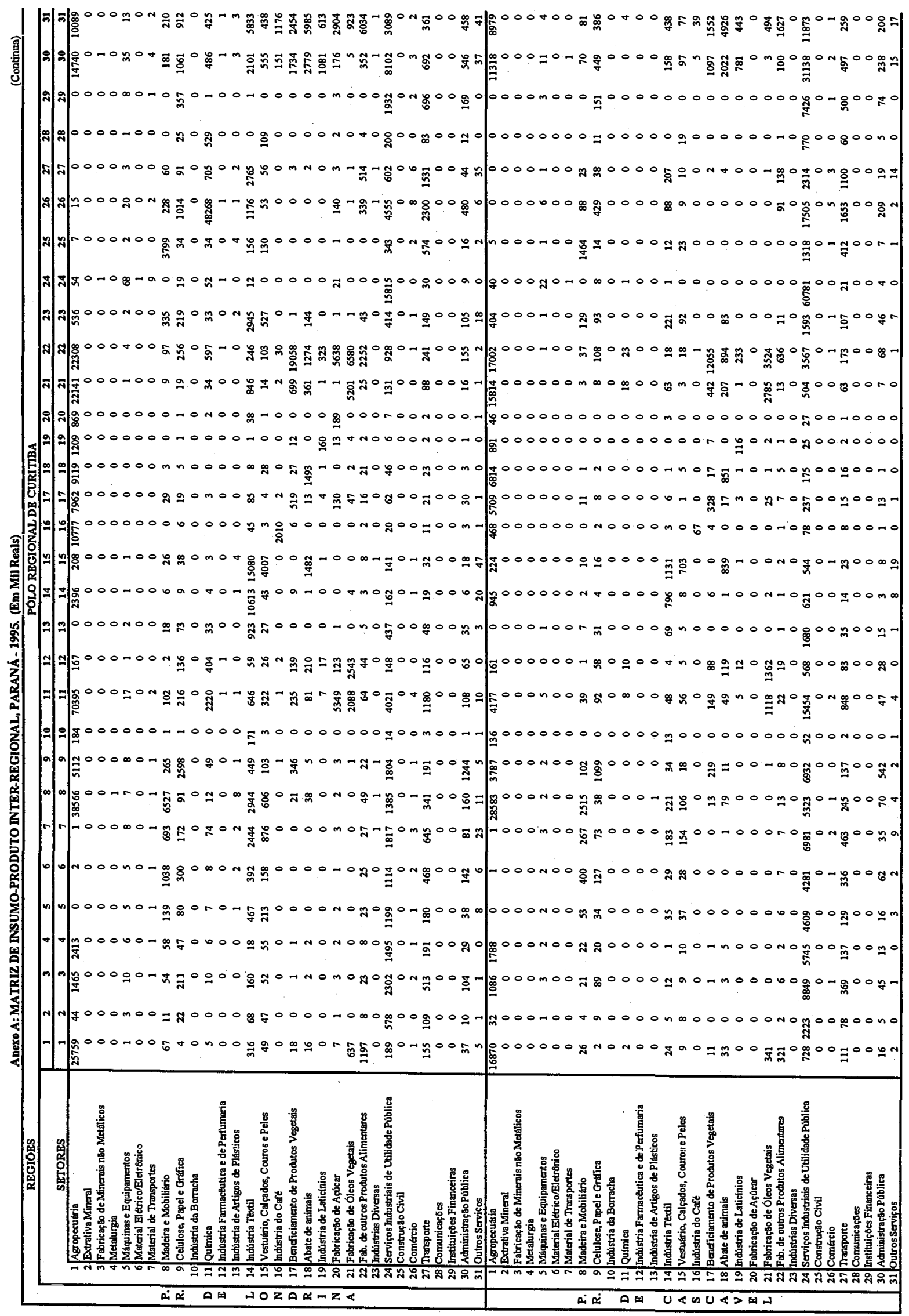




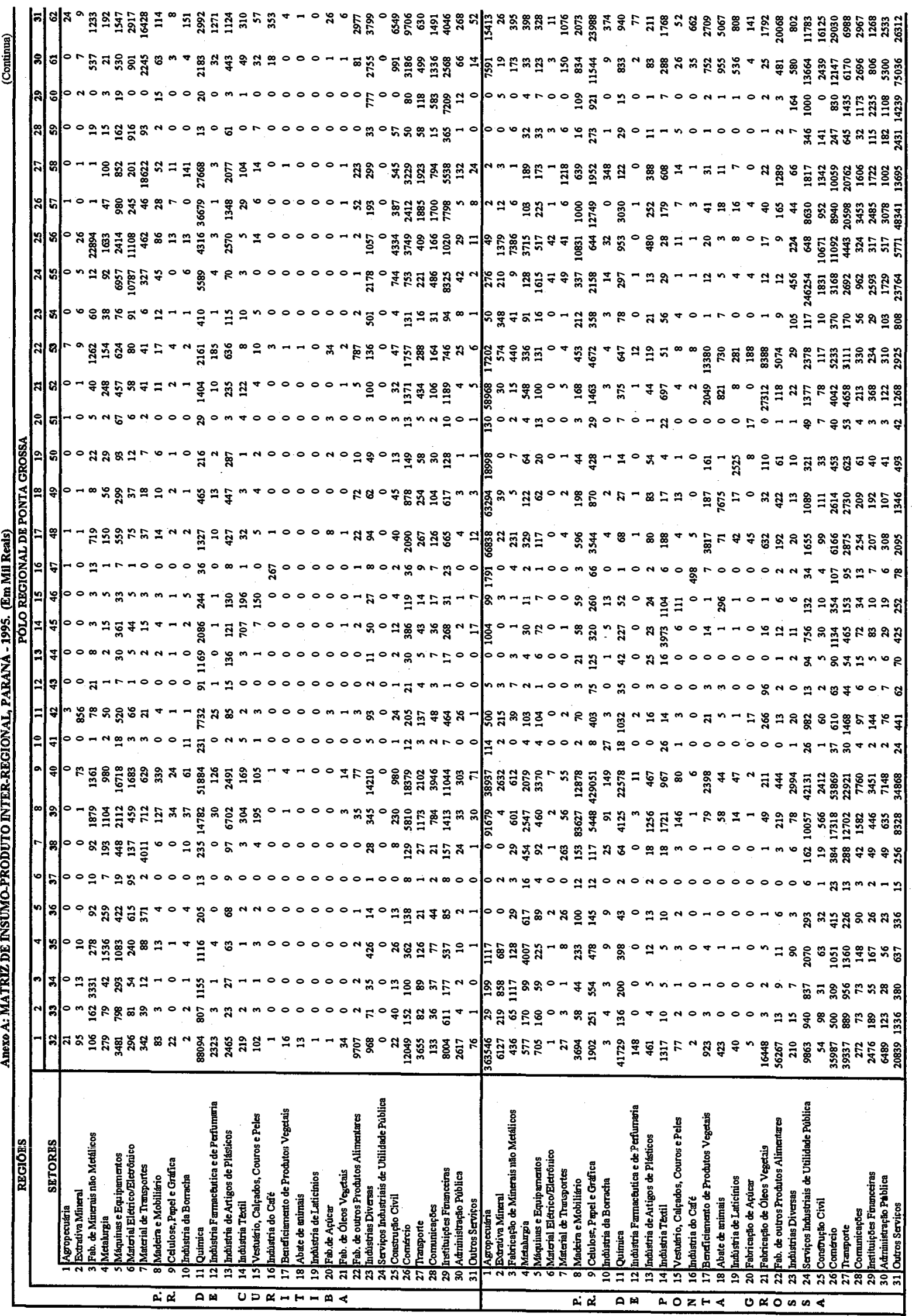




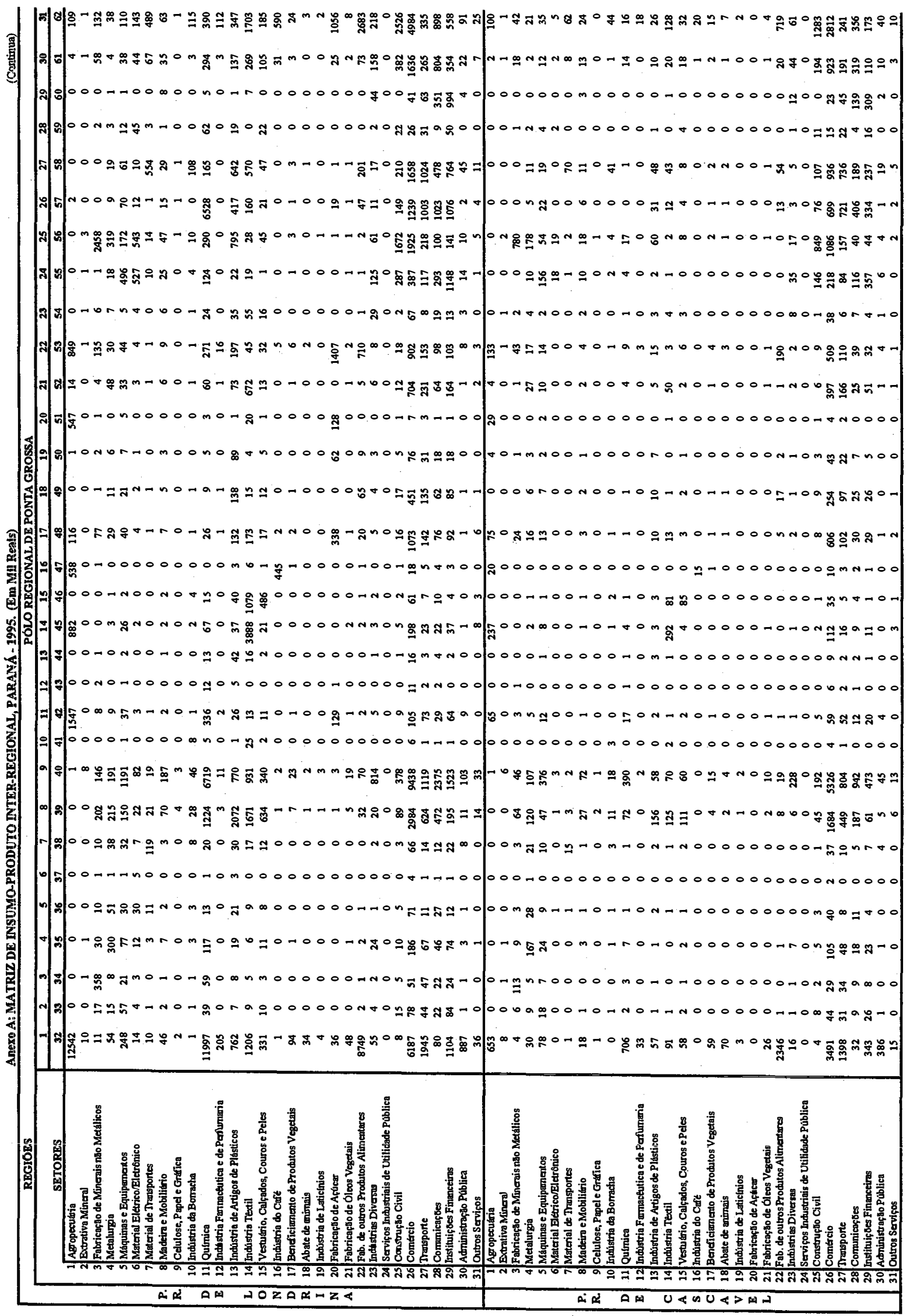




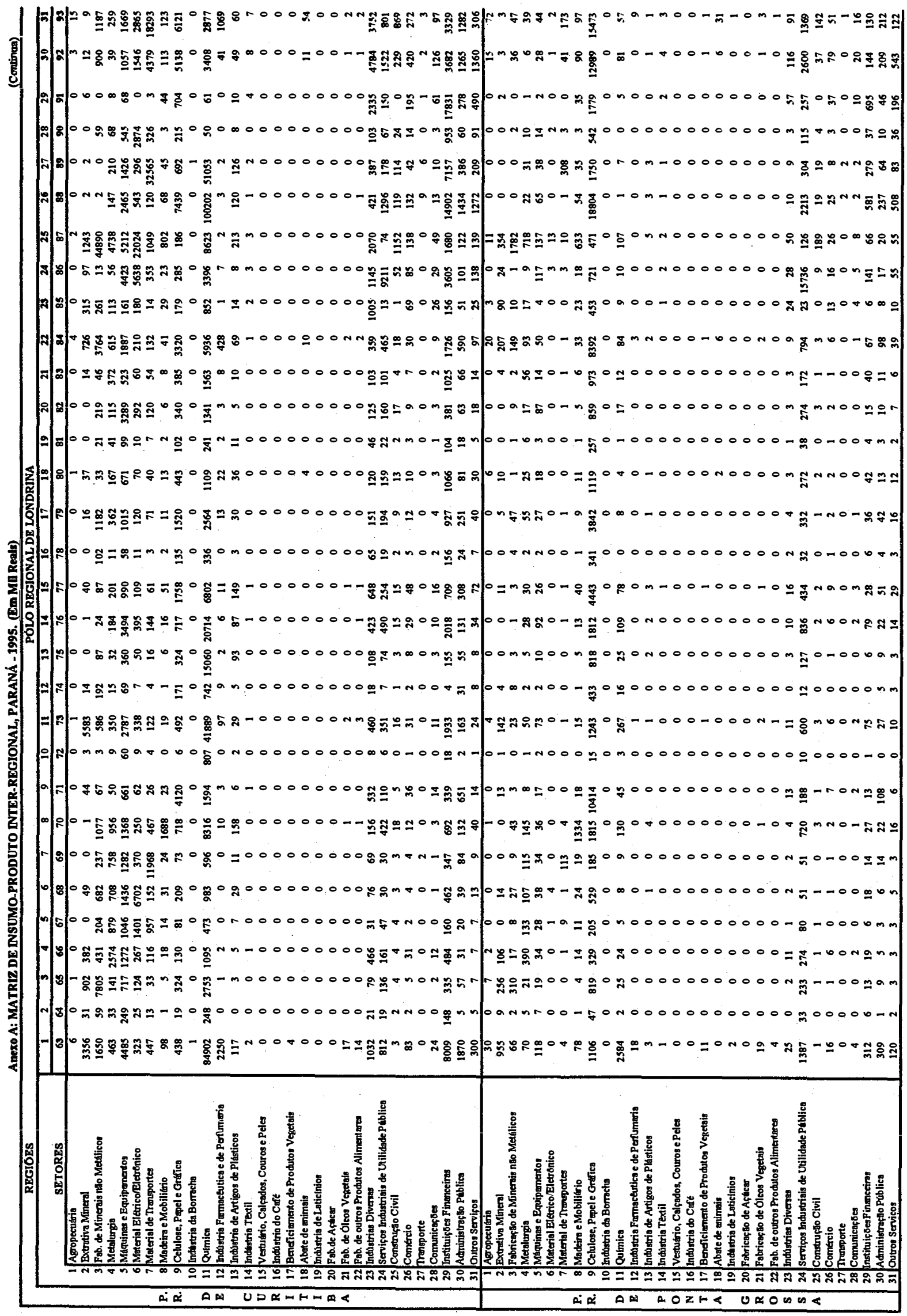




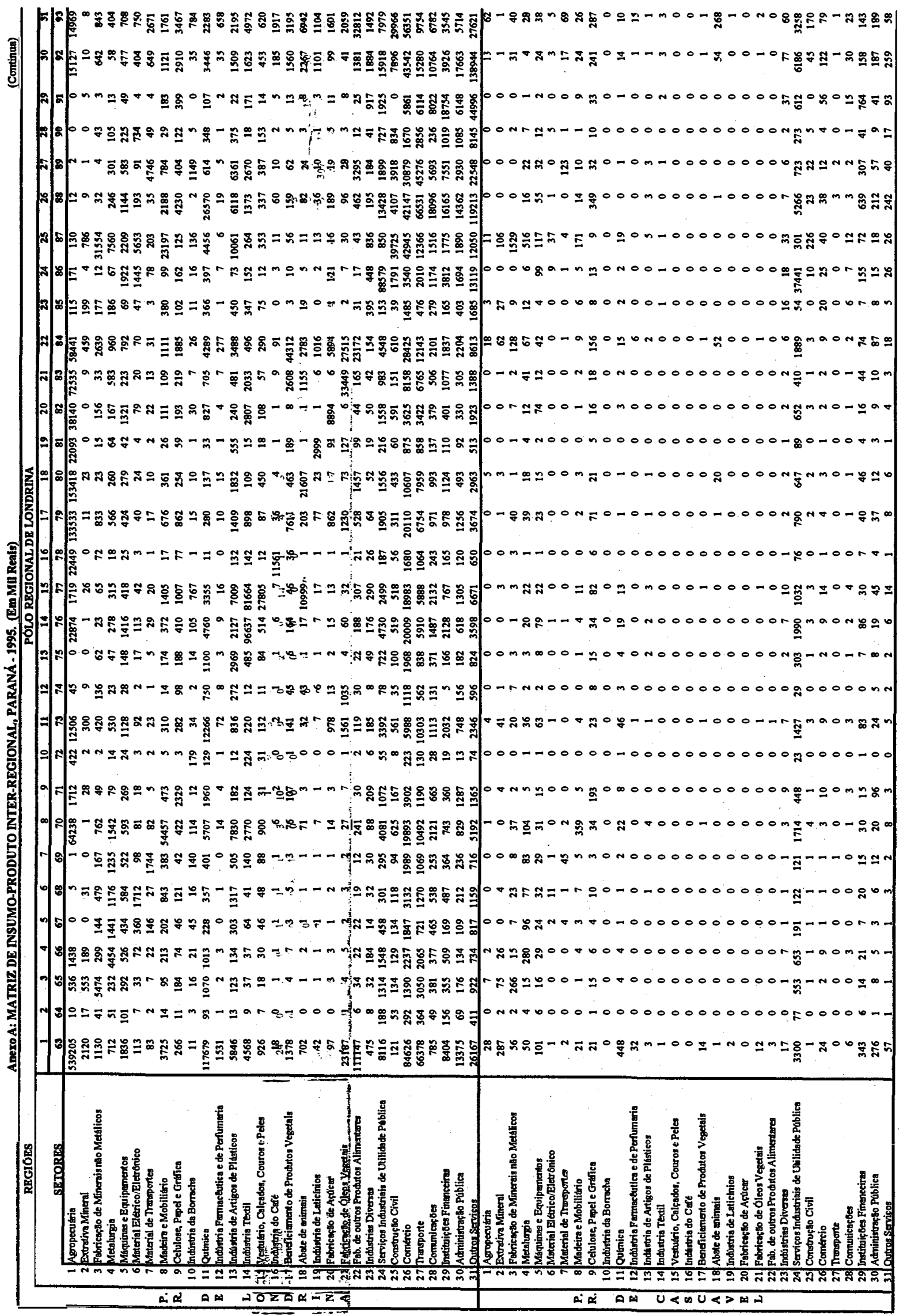




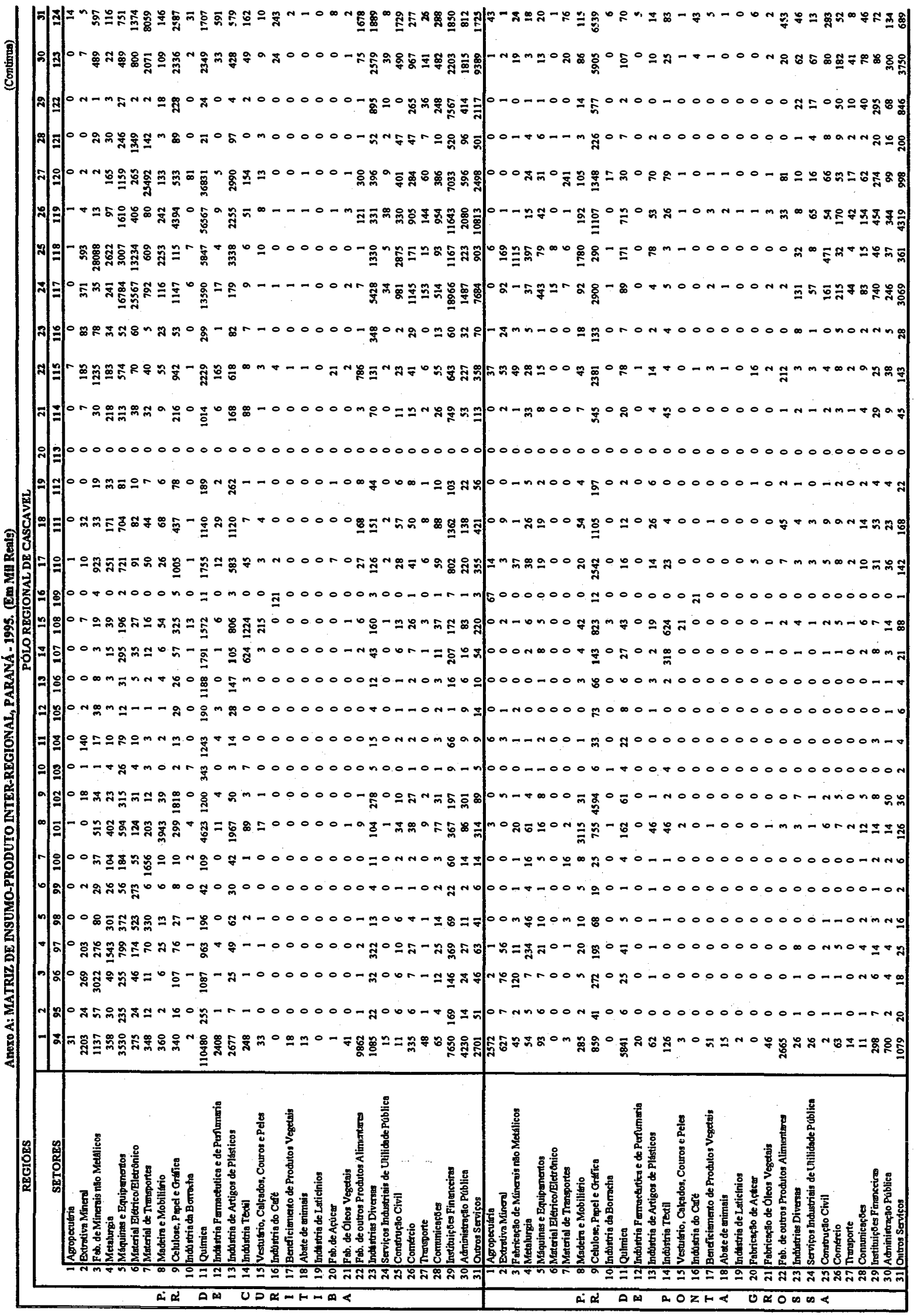




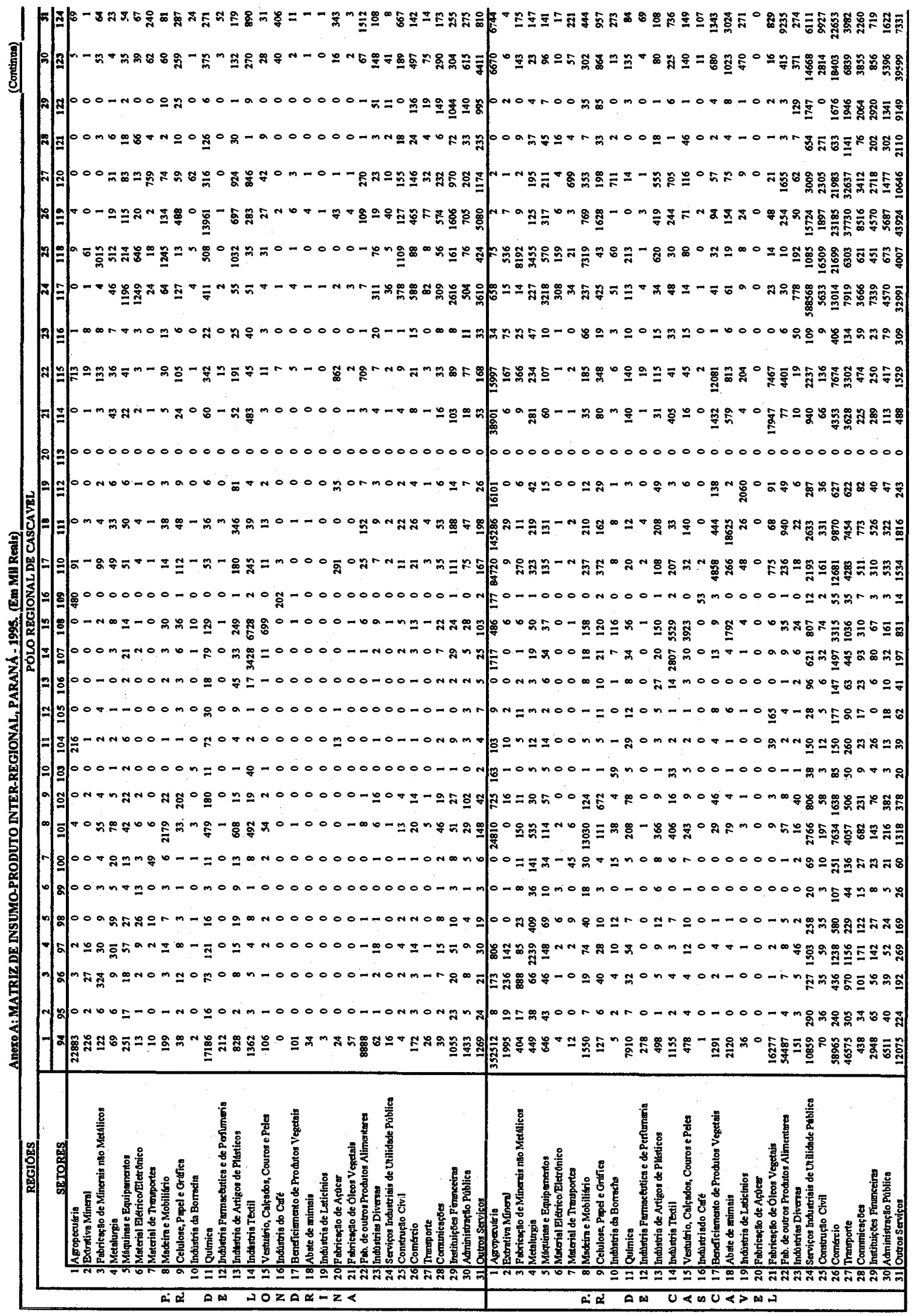




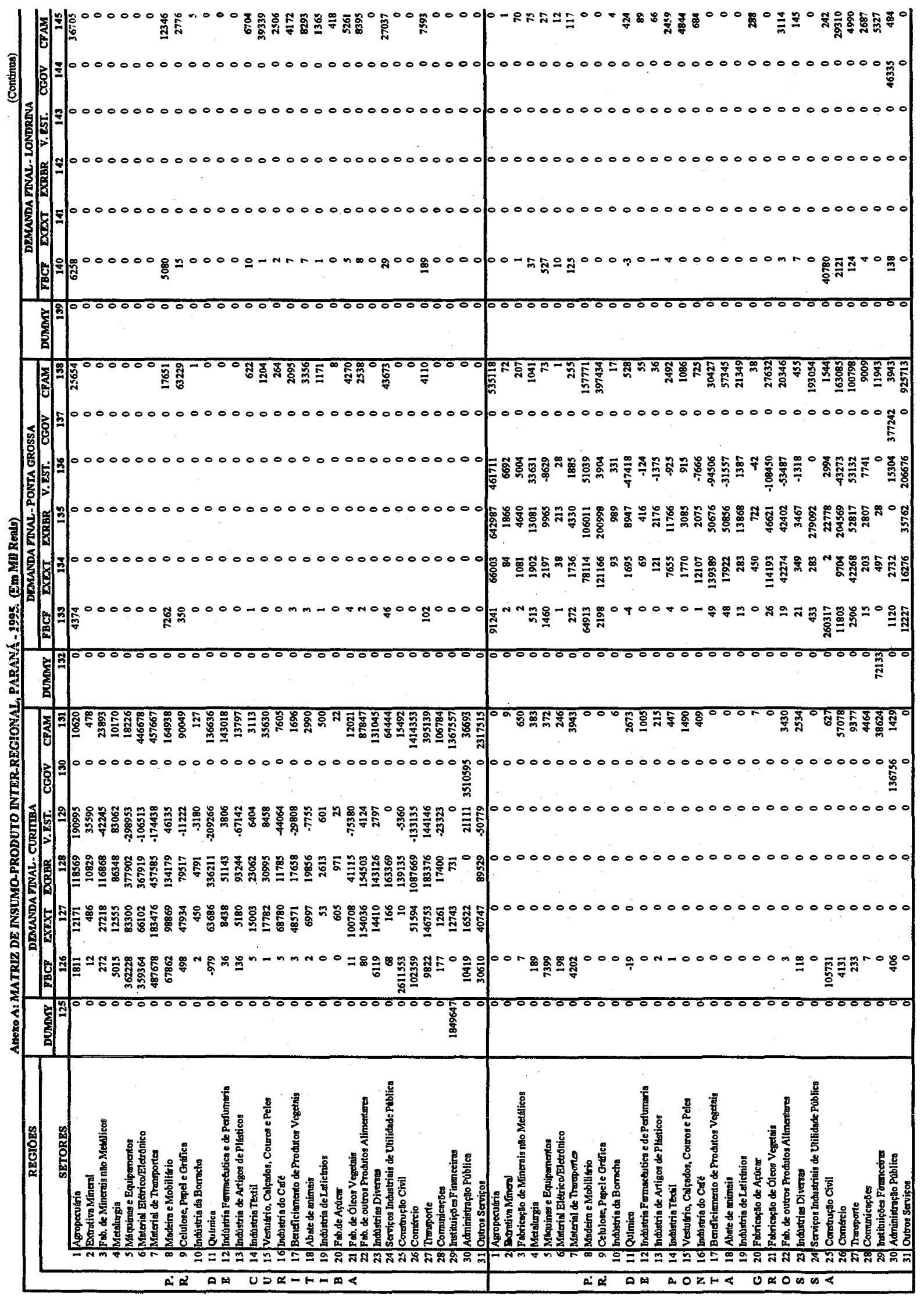




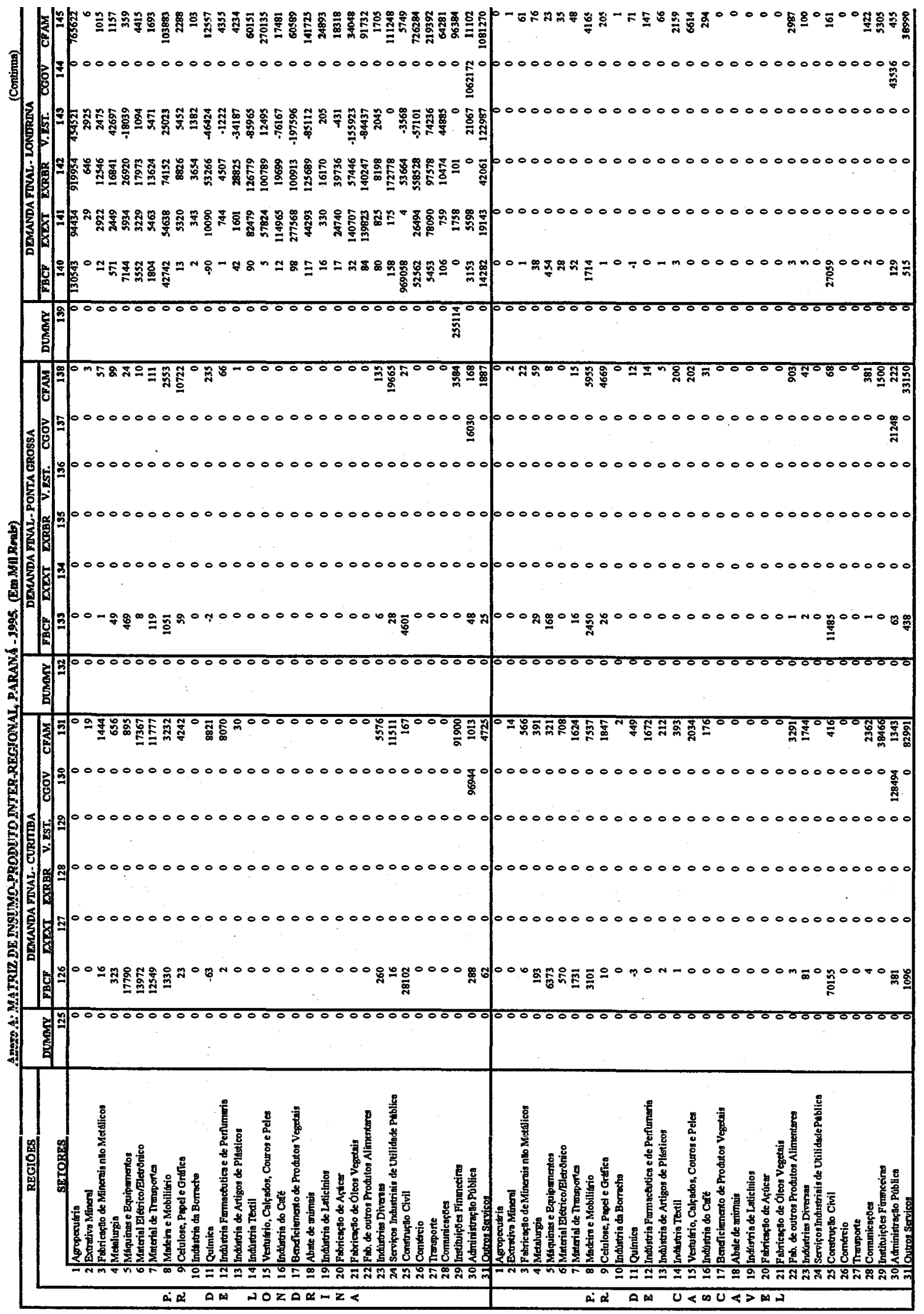




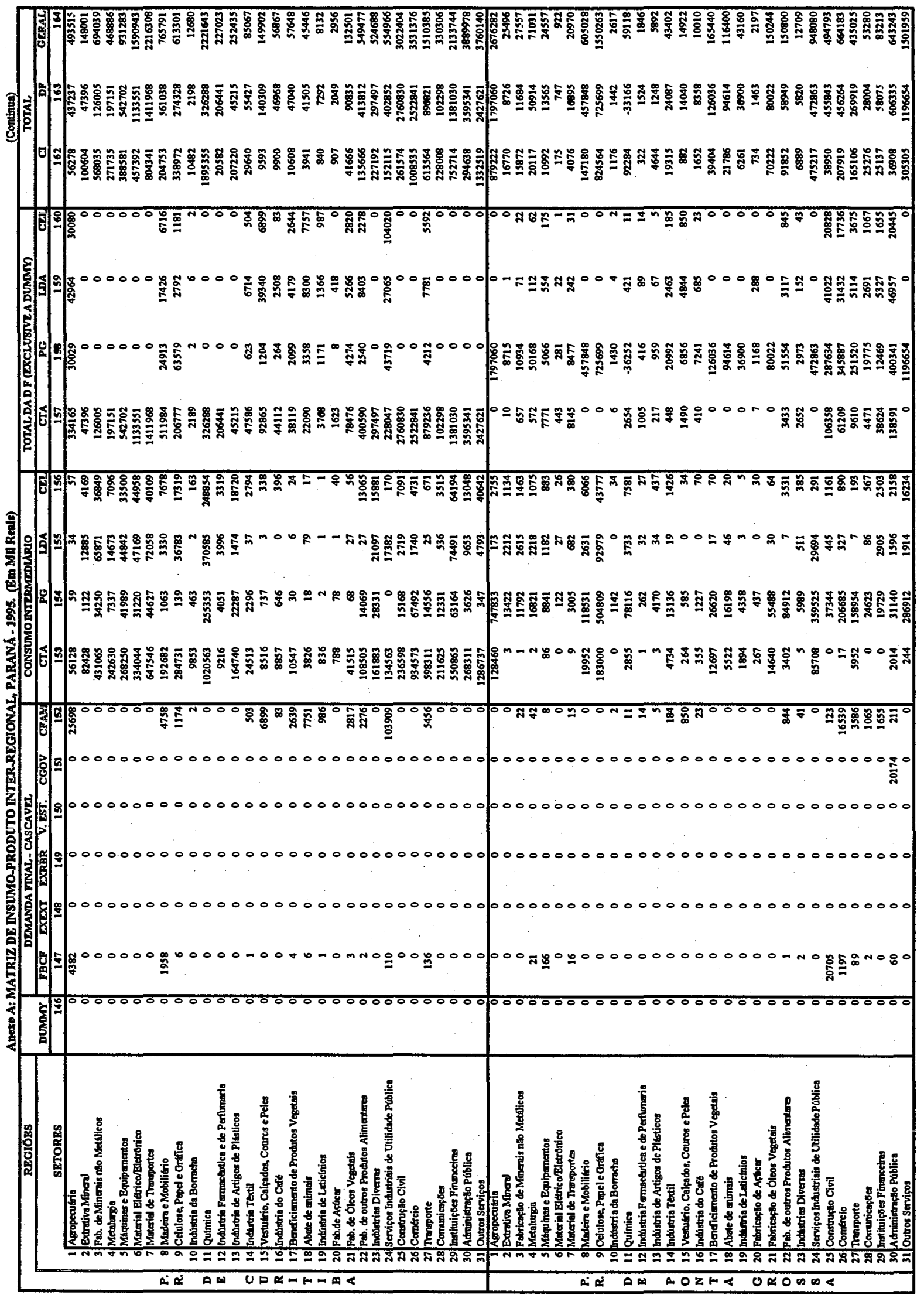




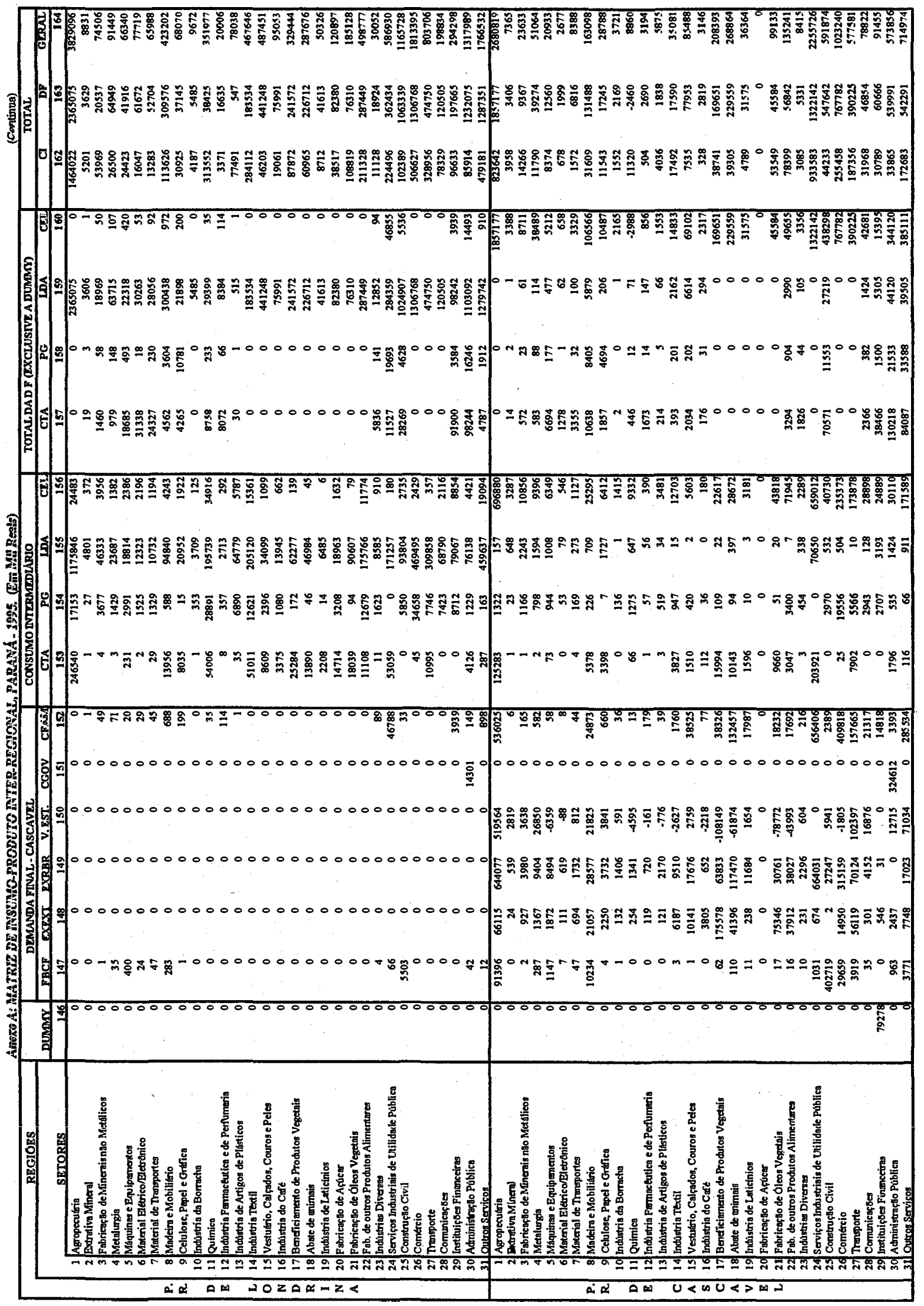



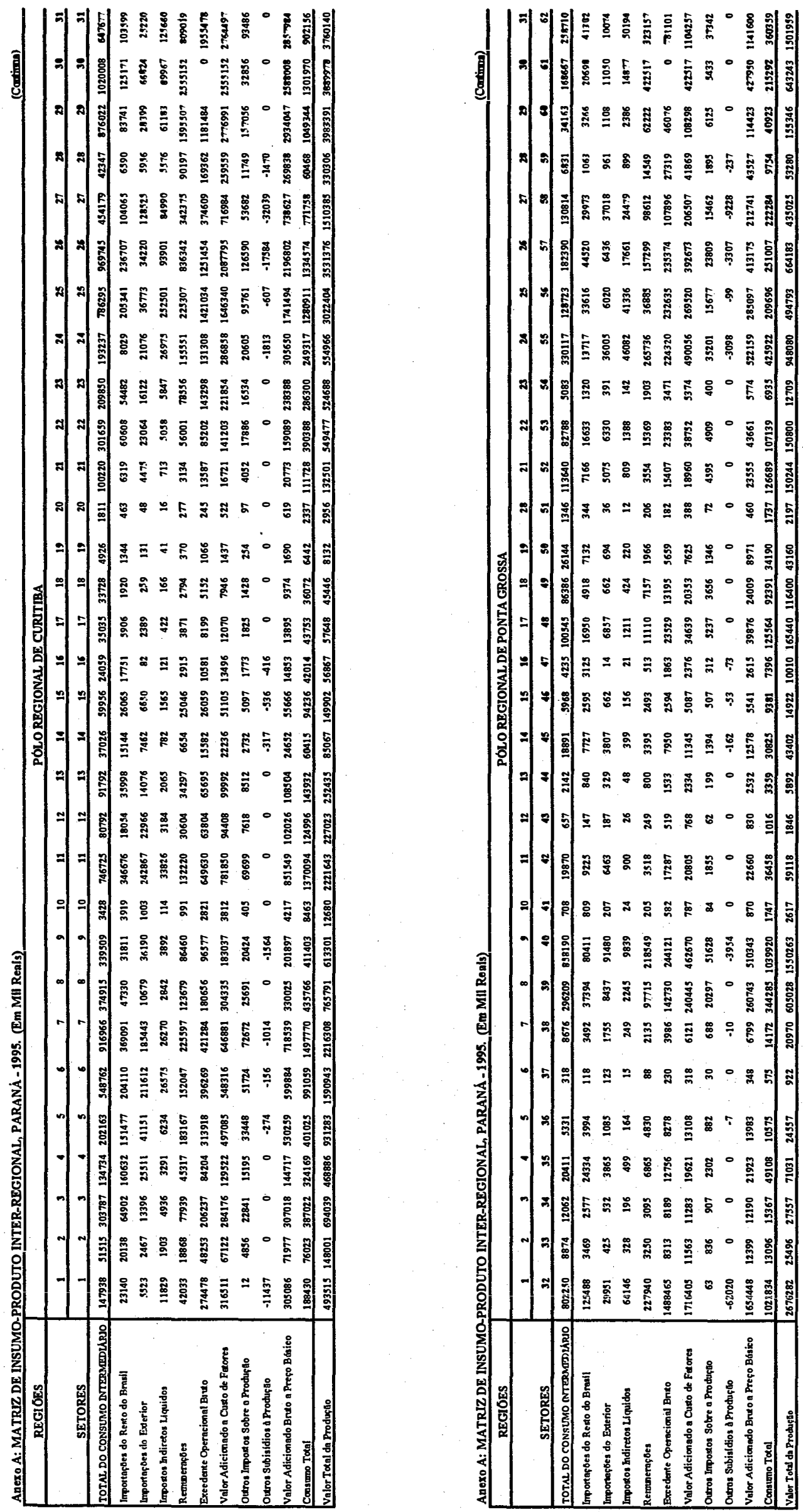

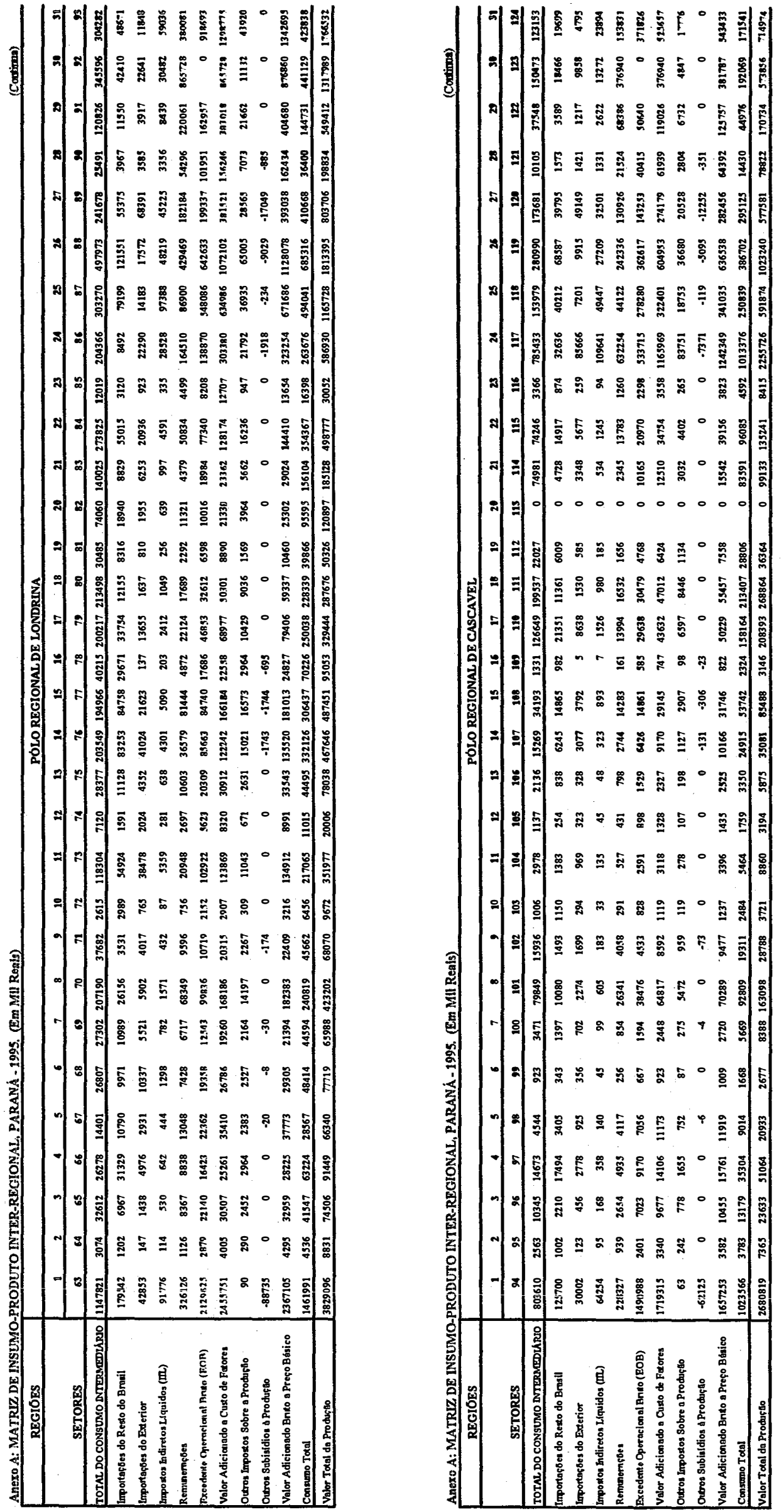

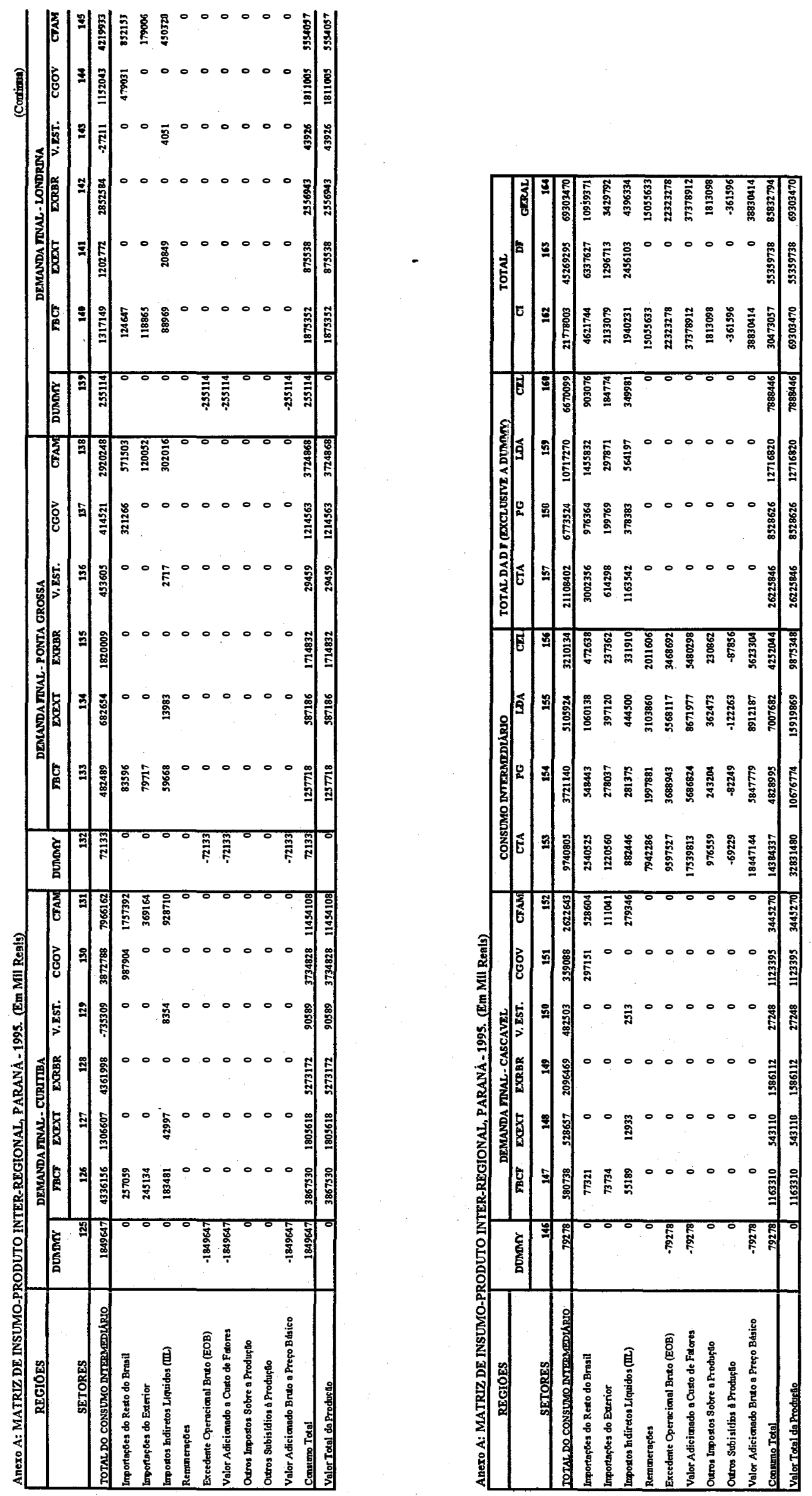


\section{REFERÊNCIAS BIBLIOFRÁFICAS}

BACHARACH, M. Biproportional matrices and input-output change. Cambridge: Cambridge University Press, 1970. 170p.

BRASIL. Anuário Mineral Brasileiro-1996: ano base 1995. http://www.dnpm.gov.br/dnpm tr1.html (13 out. 1998)

BRESSER PEREIRA, L. C. Desenvolvimento e crise no Brasil. São Paulo: Brasiliense, 1987. 207p.

CANO, W. Raízes da concentração industrial em São Paulo. 3. ed. São Paulo: Hucitec, 1990. 318p.

CARMO, J. H. do. O Paraná: sua ocupação e o desenvolver de suas atividades econômicas. Revista Paranaense de Desenvolvimento, n.76, p.33-59, jul/set. 1981.

CASTRO, D. Indústria. In: Temas estratégicos para o Paraná. Curitiba: IPARDES, 1994. p.27-49.

CAVALCANTE, J. E. Avaliação do padrão de desenvolvimento da economia do Nordeste: 1975-80. Revista Brasileira de Economia, v.48, n.1, p.107-124, jan./mar. 1994.

CELLA, G. The input-output measurement of interindustry linkages. Oxford Bulletin of Economic and Statistics, v.46, p.73-84, 1984.

CHENERY, H. Regional analysis. In: CHENERY, H.; CAO-PINA, V. The structure and growth of Italian economy. Rome: U.S. Mutual Security Agency, 1953.

CLEMENTS, B I On the decompisition and normalization of interindustry linkages Economics Letters, v. 33, p. 337-340, 1990.

CONSIDERA, C. M.; MEDINA, M. H. PIB por unidade da federação: valores corrente e constantes - 1985/96. Rio de Janeiro: IPEA, 1998. (Texto para discussão, 610). 32p. 
CONSIDERA, C. M.; RAMOS, R. L. O.; MAGALHÃES, K. M. M. et al. Matrizes de insumo-produto regionais 1985 e 1992: metodologia e resultados. Rio de Janeiro: IPEA-NEMESIS, 1997. 55p.

CROCOMO, F. C. Análise das relações inter-regionais e intersetoriais na economia brasileira em 1985: uma aplicação de insumo-produto. Piracicaba, 1998. 179p. Tese (Doutorado) - Escola Superior de Agronomia "Luiz de Queiroz", Universidade de São Paulo.

DAVIS, H. C. Multiregional input-output techniques and western water resources development. Berkeley: University of California, 1968. 142p.

FARINA, E. M. M. Q.; ZYLBERSZTAJN, D. Organização das cadeias agroindustriais de alimentos. In: Encontro Nacional de Economia, 20, Campos do Jordão - São Paulo, 1992. Anais. Rio de Janeiro: ANPEC, 1992. p.189-208.

FERNANDES, C. L. L. A inserção de Minas na economia nacional: uma análise de inumo-produto inter-regional. Rio de Janeiro, 1997. 209p. Tese (Doutorado) Instituto de Economia, Universidade Federal do Rio de Janeiro.

FUNDAÇÃO INSTITUTO BRASILEIRO DE GEOGRAFIA E ESTATÍSTICA. Matriz de Insumo-produto: Brasil - 1995. Rio de Janeiro: IBGE, 1997. 217p.

FUNDAÇÃO INSTITUTO BRASILEIRO DE GEOGRAFIA E ESTATÍSTICA. Censo agropecuário 1995-1996: Brasil (compact disc). Rio de Janeiro: IBGE, 1998.

FUNDAÇÃO INSTITUTO BRASILEIRO DE GEOGRAFIA E ESTATÍSTICA. Censo agropecuário 1995-1996: Paraná (compact disc). Rio de Janeiro: IBGE, 1998.

FURTADO, C. Formação econômica do Brasil. 18. ed. São Paulo: Companhia Editora Nacional, 1982. 248p.

GUILHOTO, J. J. M.; SONIS, M.; HEWINGS, G. J. D.; MARTINS, E. B. Índices de ligações e setores-chave na economia brasileira: 1959/80. Pesquisa e Planejamento Econômico, v.24, n.2, p.287-314, ago. 1994.

GUILHOTO, J. J. M. Um modelo computável de equilíbrio geral para o planejamento e análise de politicas agrícolas (PAPA) na economia brasileira. Piracicaba, 1995. 258p. Tese (Livre-Docência) - Escola Superior de Agricultura "Luiz de Queiroz", Universidade de São Paulo.

GUILHOTO, J. J. M.; SONIS, M.; HEWINGS, G. J. D. Linkages and multipliers in a multiregional framework: integration of alternative approaches. Urbana: University of Illinois. Regional Economics Applications Laboratory, 1996. 20p. (Discussion Paper, 96-T-8). 
GUILHOTO, J. J. M.; HEWINGS, G. J. D.; SONIS, M. Interdependence, linkeges and multipliers in Asia: an international input-output analysis. Urbana: University of Illinois. Regional Economics Applications Laboratory, 1997. 33p. (Discussion Paper, 97-T-2).

GUILHOTO, J. J. M.; HEWINGS, G. J. D.; SONIS, M. Synergetic interctions between 2 Brasilian regions: an application of input-output linkages. 45 North American Meetings of the RSAI. Santa Fe, New Mexico, 11-14 nov., 1998.

GUILHOTO, J. J. M. Decomposition \& synergy: a study of the interactions and dependence among the 5 brasilian macro regions. Dublin, Irland: 39 European Congress of the ERSARSAI, 1999. 23p.

GUILHOTO, J. J. M.; HEWINGS, G. J. D.; SONIS, M. Produtive relations in the northest and the rest of Barazil regions in 1992: decomposition \& synergy in inputoutput systems. In: ENCONTRO NACIONAL DE ECONOMIA, 27, Belém, 1999. Anais, v2. Rio de Janeiro: ANPEC, 1999. p.1437-1450.

HADDAD, P. R.; ANDRADE, T. Política fiscal e desequilíbrios regionais. Estudos Econômicos, v.4, n.1, p.9-54, jan/maio. 1974.

HADDAD, P. R. Contabilidade social e economia regional: análise de insumoproduto. Rio de Janeiro: Zahar Ed., 1976. 242p.

HADDAD, P. R. Análise de insumo-produto regional e inter-regional: multiplicadores de produção, de renda e de emprego. In: HADDAD, P. R. (Org.). Economia regional: teoria e métodos de análise. Fortaleza: BNB/ETENE, 1989. p.287-363.

HANSEN, W.; TIEBOUT, C. An intersectorial flow analysis of the California economy. The Review of Economics and ststistics, v.45, n.4, p. 409-418, 1963.

HIRSCHMAN, A. O. The strategy of economic development. New Haven: Yale University Press, 1958. 217p.

INSTITUTO PARANAENSE DE DESENVOLVIMENTO ECONÔMICO E SOCIAL. Paraná: economia e sociedade. Curitiba: IPARDES, 1982. 72p.

INSTITUTO PARANAENSE DE DESENVOLVIMENTO ECONÔMICO E SOCIAL. Articulação sócio-econômica e energia do Paraná. Curitiba: IPARDES, 1986. 36p.

INSTITUTO PARANAENSE DE DESENVOLVIMENTO ECONÔMICO E SOCIAL. Estrutura produtiva paranaense. Análise Conjuntural, v.13, n.3, p.2-4, mar. 1991.

INSTITUTO PARANAENSE DE DESENVOLVIMENTO ECONÔMICO E SOCIAL. PIB do Paraná 1980-95. Curitiba: IPARDES, 1997a. 27p. 
INSTITUTO PARANAENSE DE DESENVOLVIMENTO ECONÔMICO E SOCIAL. Paraná: comércio exterior. Curitiba: SEPL/IPARDES, n. 1, dez. 1997b. p. 45.

INSTITUTO PARANAENSE DE DESENVOLVIMENTO ECONÔMICO E SOCIAL. Produto Interno Bruto do Paraná: dados municipais - 1995. Curitiba: IPARDES, jul. 1998. 32p.

ISARD, W. Interregional and regional input-output analysis: a model of a spaceeconomy. Review of Economics and Statistics, n.33, p.319-328, 1951.

ISARD, W. Regional commodity balance and interregional commodity flows. American Economic Review, n.43, p.167-180, 1953.

ISARD, W. Location analysis for industry and service trades: comparative cost and other approaches. In: ISARD, W.; AZIS, I. J.; DRENNAN, M. P. et al. Methods of interregional and regional analysis. England: Ashgate, 1998. p.7-39.

KURESKI, R. Análise das relações intersetoriais do complexo industrial da madeira do Paraná - 1985. Curitiba: 1999. 120p. Dissertação (Mestrado) - Setor de Ciências Agrárias, Universidade Federal do Paraná.

LEÃO, I. Z. C. C. Os anos 80 e o Paraná. Análise Conjuntural, v.13, n.7-8, p.17-20, jul/ago. 1991.

LEONTIEF, W.; STROUT, A. Multiregional input-output analysis. In: BARNA, T (Org.) Structural interdependence and economic development. New York: Macmillan, 1967. p.119-150.

LEONTIEF, W. A economia do insumo-produto. São Paulo: Abril Cultural, 1983. 226p.

LEONTIEF, W.; HOFFENBERG, M. Os efeitos econômicos do desarmamento (1961). In: LEONTIEF, W. A economia do insumo-produto. São Paulo: Abril Cultural, 1983. cap. 9, p.97-102.

LEONTIEF, W.; MORGAN, A.; POLENSKE, K. et al. O impacto econômico industrial de uma redução de armas (1965). In: A economia do insumo-produto. São Paulo: Abril Cultural, 1983. cap. 10, p.103-116.

LIVORATTI, P. SP iniciou descentralização nos anos 60 . Folha de Londrina. Economia, Londrina, 20 dez. 1998.

LOURENÇO, G. M. Evolução recente e perspectivas das economias regionais segundo a F.G.V. Análise Conjuntural, v.16, n.1-2, p.3-6, jan/fev. 1994. 
LOURENÇO, G. M. Expansão recente da economia paranaense: componentes estruturais e conjunturais. Análise Conjuntural, v.17, n.3-4, p.20-25, mar/abr. 1995.

LOURENÇO, G. M. A produção industrial paranaense em 1995. Análise Conjuntural, v.18, n.1-2, p.19-21, jan/fev. 1996a.

LOURENÇO, G. M. Atração de empresas e concentração industrial no Paraná. Análise Conjuntural, v.18, n.11-12, p.3-12, nov/dez. 1996b.

LUGON, C. A república comunista cristã dos guaranis. Rio de Janeiro: Paz e Terra, 1968. 353p.

MAGALHÃES FILHO, F. Evolução histórica da economia paranaense. Revista Paranaense de Desenvolvimento, n.87, p.131-148, jan/abril. 1996.

MARTINS, A. R. Historia do Paraná. 2. ed. São Paulo: Rumo, 1939. 538p.

McGILVRAY, J. Linkages, key sectors and development strategy. In: LEONTIF, W. (Ed.). Structure, system and economc policy. Cambridge: University Press, 1977. p.49-56.

METZLER, L. A multiple-regiao theory of income and trade. Econometrica, v. 8, p.329-354, out. 1950.

MIERNYK, W. H. Elementos de análise do insumo-produto. São Paulo: Atlas, 1974. $164 p$.

MILLER, R. E. ; BLAIR, P. D. Input-output analysis: foundations and extensions. Englewood Cliffs: Prentice-Hall, 1985. 464p.

MIYAZAWA, K. Input-output analysis and the structure of income distribution. Berlin: Springer-Verlag, 1976. 135p.

MIYAZAWA, K. Internal and external matrix multipliers in the input-output model. Hitotsubashi Journal of economics, n. 7, v. 1, p. 38-55, 1966.

MONTOYA, M. A. A matriz insumo-produto internacional do Mercosul para 1990, as desigualdades regionais e os impactos intersetoriais do comércio inter-regional. Piracicaba, 1998. 175p. Tese (Doutorado) - Escola Superior de Agronomia "Luiz de Queiroz", Universidade de São Paulo.

MONTOYA, M. C.; GULHOTO, J. J. M. The interregional and intersectoral structure of mercosur: an application of input-output analysis. Australian Journal of Regional Studies. v.4, n. 1, p.93-112, 1998. 
MOSES, L. The stability of interregional trading patterns and input-output analysis. The American Economic Review, n.45, p.803-832, 1955.

NOJIMA, D. Considerações sobre produtividade e geração de emprego na indústria paranaense nos anos recentes. Análise Conjuntural, v.17, n.11-12, p.9-15, nov/dez. 1995.

PADIS, P. C. Formação de uma economia periférica: o caso do Paraná. São Paulo: Hucitec; Curitiba: Secretaria da Cultura e Esporte do Governo do Paraná, 1981. 235p.

PARANÁ (Estado). Secretaria de Estado da Fazenda. Assessoria Econômica EEF/R05. Curitiba: CELEPAR, 1997. p.26-281.

POLENSKE, K. An empirical test of interregional input-output models: estimation of 1963 japonese production. American Economic Review, p. 76-82, May, 1970.

RASMUSSEN, P. Studies in intersectoral relations. Amsterdam, North Holland, 1956.

ROESING, A. C.; SANTOS, A. B. Descrição sucinta da cadeia produtiva da soja na região Sul do Brasil. Informe Econômico CNPSo, v. 3, n. 1, p.36-56, out. 1997.

ROLIN, C. F. C. O Paraná urbano e o Paraná do agrobusiness: as dificuldades para a formulação de um projeto político. Revista Paranaense de Desenvolvimento, n.86, p.49-99, set/dez. 1995

ROUND, J. I. Nonsurvey techniques: a critical review of the theory and the evidence. International Reginal Science Review, v. 8, n. 3, p. 189-121, 1983.

SANDRONI, P. Dicionário de economia. São Paulo: Best Seller, 1989. 331p.

SILVA, J. G. da. A estrutura agrária do Estado do Paraná. Revista Paranaense de Desenvolvimento, n. 87, p.175-195, jan/abr. 1996.

SONIS, M.; HEWINGS, G. J. D. Error and sensitivity input-output analysis: a new approach. In: MILLER, R. E.; POLENSKE, K. R.; ROSE, A. Z. (Ed.). Frontiers of Input-Output Analysis. New York: Oxford University Press, 1989.

SONIS, M.; HEWINGS, G. J. D. Fields of infinence in input-output systems. Urbaña: University of Illinois. Regional Economics Applications Laboratory, 1994. (mimeo)

SONIS, M.; HEWINGS, G. J. D. Multiplier product matrix analysis for multirregional input-output analysis. s.l. s.ed. /1999?/ 
SONIS, M.; HEWINGS, G. J. D; GUO, J. Input-output multiplier product matrix. Urbana: University of Illinois. Regional Economics Applications Laboratory, 1997. (Discussion Paper, 94-T-12).

SONIS, M.; HEWINGS, G. J. D; GUO, J. Comparative analysis of China's metropolitan economies: an input-output perspective. s.n.t.

SONIS, M.; HEWINGS, G. J. D; MIYAZAWA, K. Synergetic interctions within the pair-wise hirarchy of economic linkges sub-sistems. Hitotsubashi Journal of Economics, n. 38, p. 2-17, dez. 1997.

SONIS, M.; HEWINGS, G. J. D. Economic landscapes: multiplier product matrix analysis for multirregional input-output systems. Hitotsubashi Journal of Economics, v.40, n.1, p.59-74, 1999.

SOUZA, N. de J. Metodologia de obtenção das matrizes de insumo-produto dos estados da região sul, 1985 e 1995. Porto Alegre: UFRGS, 1997. (Texto para discussão, 97/14). 15p.

URBAN, M. L. P. Dilemas da economia paranaense. Revista Paranaense de Desenvolvimento, n.84, p.13-17, jan/abr. 1995.

VOLACO, G.; BAGGIO, E. C. ; SHIBATA, E. K.; LOURENÇO, G.M. Economia paranaense: desempenho recente e cenários de curto prazo. Análise Conjuntural, v.13, n.4, p. 1-9, abr. 1991.

WOSCH, L. F. As exportações paranaenses: expectativas superadas em 1995. Análise Conjuntural, v. 18, n. 1-2, p. 17-19, jan/fev. 1996. 